\title{
WestVirginiaUniversity
}

THE RESEARCH REPOSITORY @ WVU

Graduate Theses, Dissertations, and Problem Reports

2001

\section{New catalysts for syngas production from carbon dioxide and methane}

Mahesh Venkataraman lyer

West Virginia University

Follow this and additional works at: https://researchrepository.wvu.edu/etd

\section{Recommended Citation}

lyer, Mahesh Venkataraman, "New catalysts for syngas production from carbon dioxide and methane" (2001). Graduate Theses, Dissertations, and Problem Reports. 1196.

https://researchrepository.wvu.edu/etd/1196

This Thesis is protected by copyright and/or related rights. It has been brought to you by the The Research Repository @ WVU with permission from the rights-holder(s). You are free to use this Thesis in any way that is permitted by the copyright and related rights legislation that applies to your use. For other uses you must obtain permission from the rights-holder(s) directly, unless additional rights are indicated by a Creative Commons license in the record and/ or on the work itself. This Thesis has been accepted for inclusion in WVU Graduate Theses, Dissertations, and Problem Reports collection by an authorized administrator of The Research Repository @ WVU. For more information, please contact researchrepository@mail.wvu.edu. 


\title{
New Catalysts for Syngas Production from Carbon Dioxide and Methane
}

\author{
Mahesh V. Iyer \\ Thesis submitted to the College of Engineering and Mineral Resources at \\ West Virginia University \\ in partial fulfillment of the requirements \\ for the degree of \\ Master of Science \\ in \\ Chemical Engineering
}

Edwin L. Kugler, Ph.D., Chair

Dady B. Dadyburjor, Ph.D.

Jean B. Cropley, M.S.

Department of Chemical Engineering

Morgantown, West Virginia

2001

Keywords: Methane, carbon dioxide, dry reforming, synthesis gas, cobalt tungsten carbide catalyst, reforming kinetics, langmuir-hinshelwood model

Copyright 2001 Mahesh V. Iyer 


\title{
ABSTRACT
}

\section{New Catalysts for Syngas Production from Carbon Dioxide and Methane}

\author{
Mahesh V. Iyer
}

The performance of cobalt tungsten carbide material was investigated for $\mathrm{CH}_{4} / \mathrm{CO}_{2}$ reforming. The catalyst was found to convert to a very stable, very active, form when heated in $\mathrm{CH}_{4} / \mathrm{CO}_{2}$ at $850{ }^{\circ} \mathrm{C}$ and 5 atm.. Even after 90 hours on stream, $\mathrm{CH}_{4}$ and $\mathrm{CO}_{2}$ rates of 1.3 and $1.25 \mathrm{mmol} / \mathrm{min} / \mathrm{g}$ respectively are obtained, with $\mathrm{CO}$ yields of $76 \%$ and $\mathrm{H}_{2} / \mathrm{CO}$ ratio close to unity. XRD patterns suggest a phase transformation to $\mathrm{WC}+\mathrm{Co}+\mathrm{C}$. SEM images suggest formation of encapsulated carbon and whisker carbon.

The kinetics of $\mathrm{CH}_{4} / \mathrm{CO}_{2}$ reforming was studied under differential conditions over $500-600^{\circ} \mathrm{C}$. The observed rates seem to follow a Langmuir-Hinshelwood type of reaction mechanism. A scheme consisting of four reactions was considered: methane reforming, reverse water gas shift, carbon deposition and reverse boudouard. Carbon deposition and carbon removal are generally disregarded in most of the reported kinetic-models. The parameters of the model were successfully estimated. The comparison plots of the observed data and the predicted model show a good fit. 
Dedicated to my family. 


\section{ACKNOWLEDGEMENTS}

I am greatly indebted to my advisors Dr. Dady Dadyburjor and Dr. Edwin Kugler, for all the invaluable guidance, encouragement and their experiences that they shared with me, not only in research but also in my entire graduate study at West Virginia University. I am grateful to Jean Cropley, member of my research committee, for his valuable suggestions and recommendations in this research study. The financial support from US Department of Energy under cooperative agreement contract DE-FC26-99FT40540 with Consortium for Fossil Fuel Liquefaction Science is gratefully acknowledged.

I would like to sincerely thank Dr. Lawrence Norcio for his constant efforts throughout this research project. I am grateful to Dr. Mohindar Seehra, Department of Physics, WVU for performing the XRD analysis and Dr. William Chisholm, National Institute of Occupational Safety and Health (NIOSH), Morgantown, for the SEM analysis.

My sincere thanks to Jim Hall, Bonita Helmick and Linda Rogers for patiently helping me out in all my non-academic but important issues. I would like to thank every graduate student and faculty at the Chemical Engineering Department, WVU, for all their warmth and hospitality, that made my stay in Morgantown a wonderful experience to cherish forever. Personally, I would like to thank my friends Apoorva, Adam, Angela, Bala, Ganesh, Harry, Manish, Neeraj, Oguz and Raju for all the things they have done for me during my stay here.

Thank you all! 


\section{TABLE OF CONTENTS}

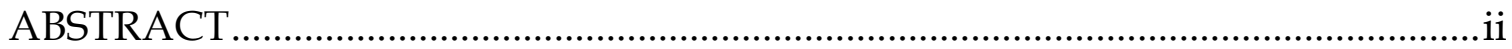

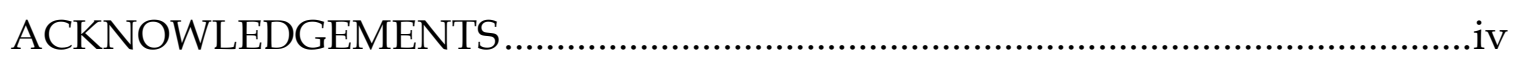

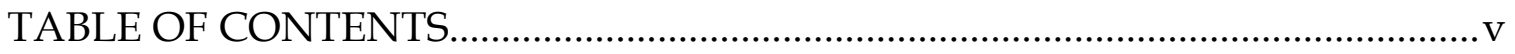

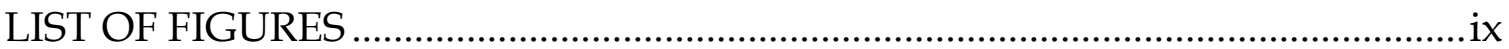

LIST OF TABLES ......................................................................................

\section{CHAPTER 1}

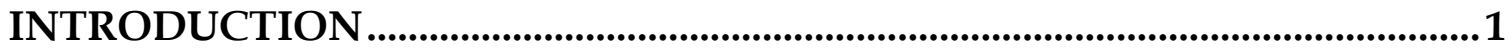

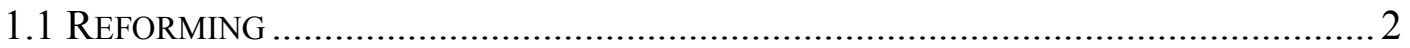

1.2 SIGNIFICANCE OF DRY REFORMING ......................................................... 2

1.3 NEED FOR NEW CATALYSTS ...................................................................... 3

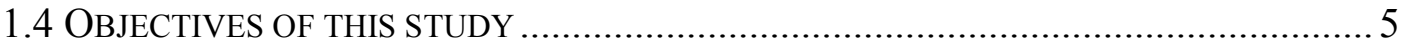

\section{CHAPTER 2}

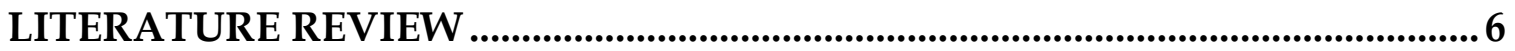

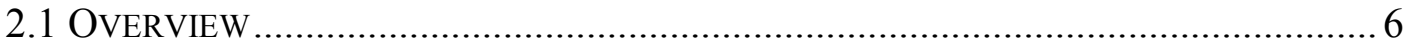

2.2 THERMODYNAMICS OF $\mathrm{CO}_{2}$ REFORMING OF METHANE ................................. 7

2.3 STUDY OF CATALYST ACTIVITY .................................................................. 9

2.3.1 Preparation ................................................................................. 9

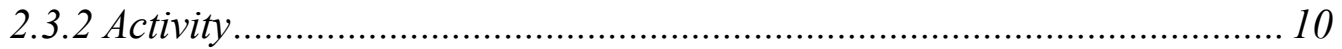

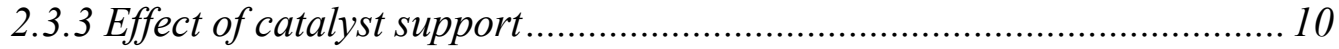

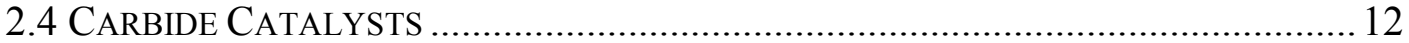

2.4.1 Tungsten Carbides................................................................................. 13

2.4.2 Molybdenum Carbides ..................................................................... 14

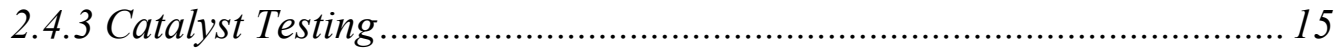

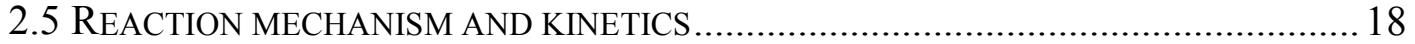

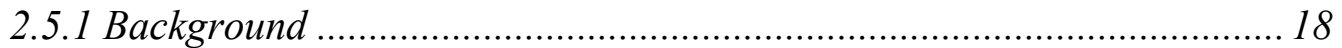

2.5.2 Power-law kinetic models................................................................ 18

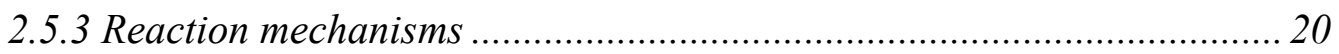

2.5.4 Adsorption based kinetic models ................................................. 27 


\section{CHAPTER 3}

EXPERIMENTAL SETUP AND PROCEDURE.........................................................34

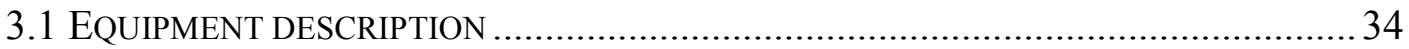

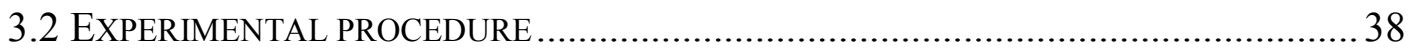

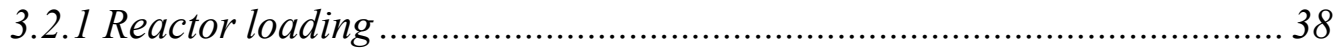

3.2.2 Pretreatment and Reaction........................................................................ 39

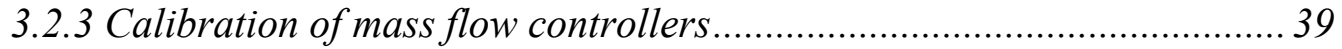

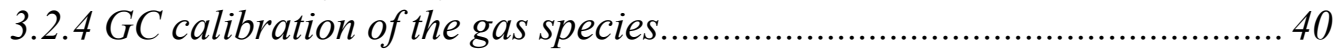

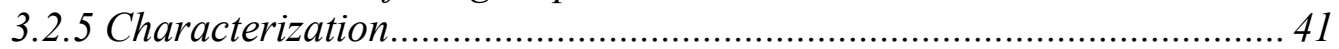

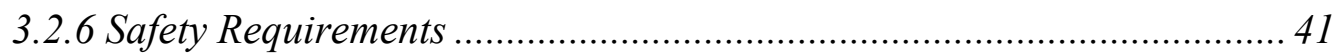

\section{CHAPTER 4}

RESULTS WITH SUPPORTED NICKEL AND PLATINUM CATALYSTS .....43

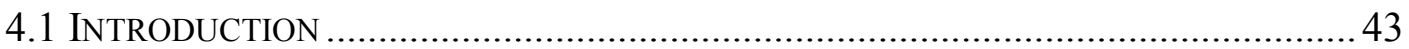

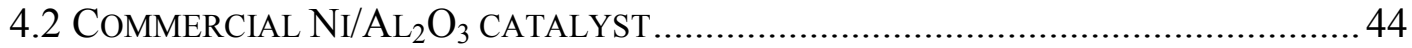

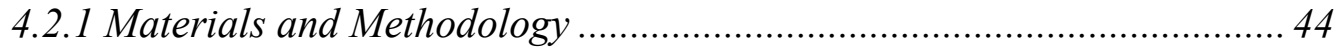

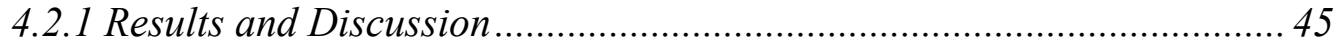

4.3 ZiRConia SuPPORTEd Platinum CATALYST ....................................................52

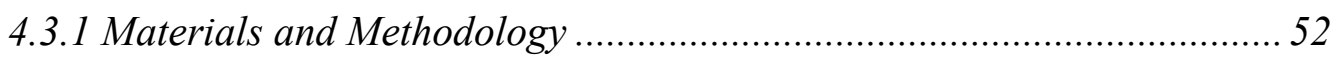

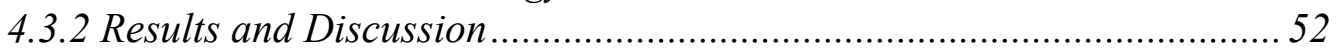

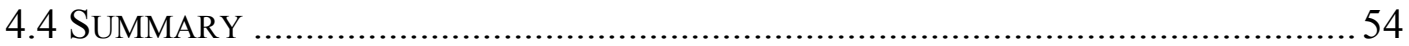

\section{CHAPTER 5}

TUNGSTEN CARBIDE CATALYST........................................................................55

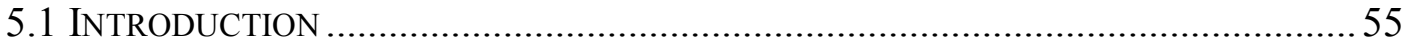

5.2 MATERIALS AND INITIAL METHOdOLOGY ……………..................................5

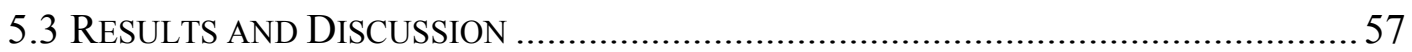

5.3.1 Preliminary Investigation with Unstabilized Catalyst ............................57

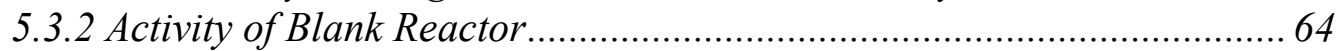

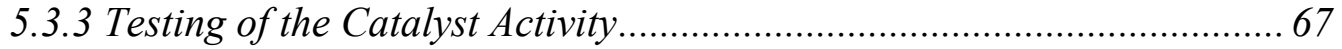

5.3.4 Characterization of the Cobalt Tungsten Carbide Catalyst.................... 74

5.3.4.1 X-ray Diffraction (XRD) Analysis ............................................ 74

5.3.4.2 Scanning Electron Microscopy (SEM) Analysis......................... 79 


\section{CHAPTER 6}

\section{REACTION KINETICS AND MODELING UNDER DIFFERENTIAL}

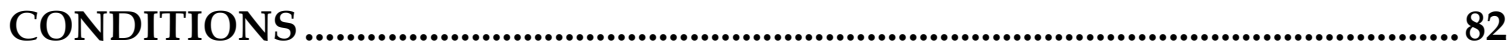

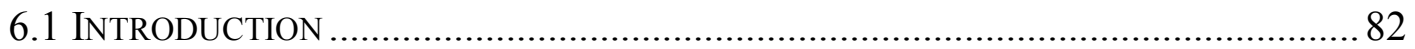

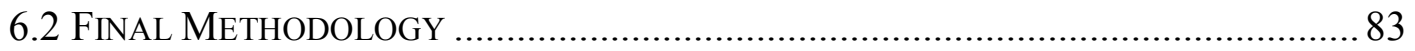

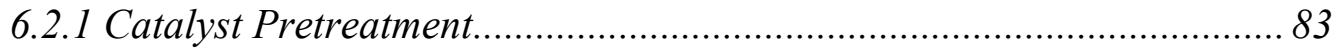

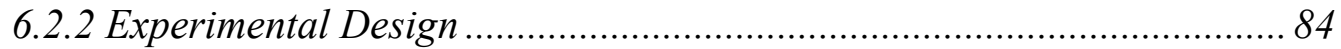

6.3 RESULTS AND DISCUSSION OF DIFFERENTIAL RUNS .......................................... 86

6.3.1 Effect of partial pressure of the reactants .............................................86 86

6.3.2 Reaction schemes and thermodynamic analysis ................................... 95

6.3.3 Power Law Model ........................................................................ 98

6.3.4 Langmuir Hinshelwood (LH) Model ................................................. 105

6.3.5 Parameter estimation for the LH model............................................. 108

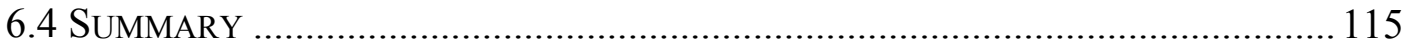

\section{CHAPTER 7}

SUMMARY AND RECOMMENDATIONS.......................................................116

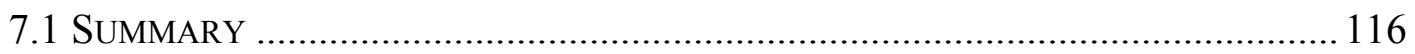

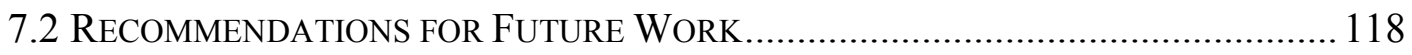

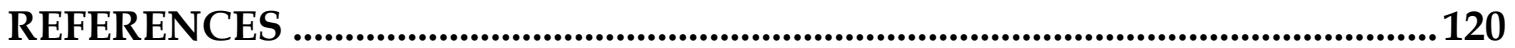

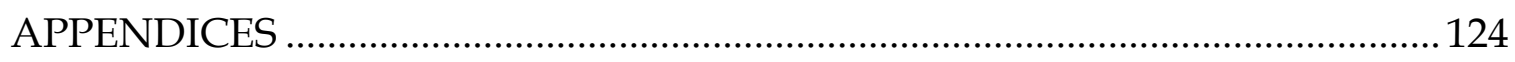

APPENDIX A: Gas Chromatograph Operating Conditions ....................................125

APPENDIX B: Calculation Procedure for Gas Chromatograph Calibration....... 128

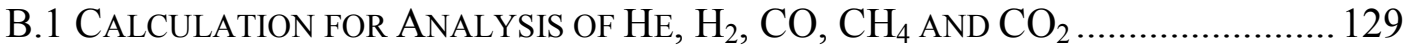

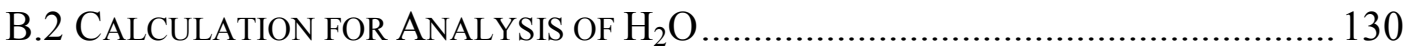

APPENDIX C: Mass Flow Controller Calibration Curves .......................................134

APPENDIX D: Calculations for Results with Supported Nickel and Platinum

Catalysts.

D.1 Calculations of Reaction Rates for Ni/AL $\mathrm{O}_{3}$ Catalyst (Without INTERNAL STANDARD)

D. 2 CAlCulations of Reaction Rates For Pt/ZRO 2 Catalyst (Without INTERNAL STANDARD) 
APPENDIX E: Calculations for the Results with Cobalt Tungsten Carbide

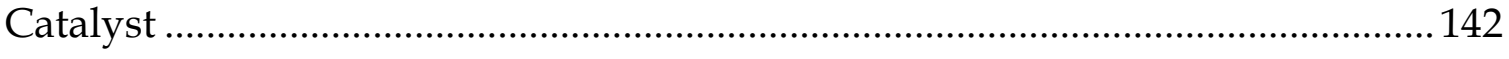

E.1 Calculation of Reaction Rates and Partial Pressures ........................ 143

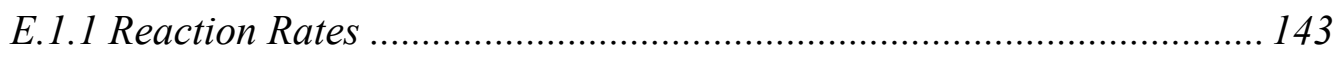

E.1.2 Partial Pressures ....................................................................... 145

E.2 CALCUlations of CONVERsions, Yield, $\mathrm{H}_{2} / \mathrm{CO}$ RATIO AND CARBON BALANCE

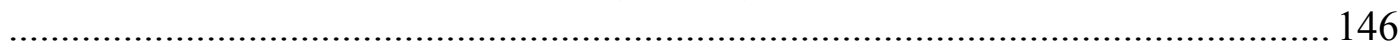

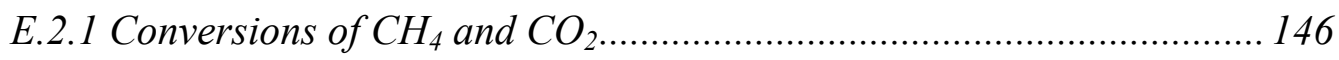

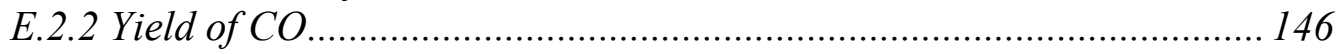

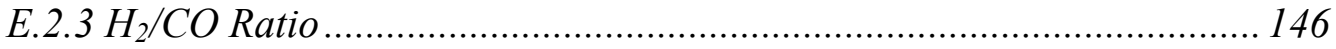

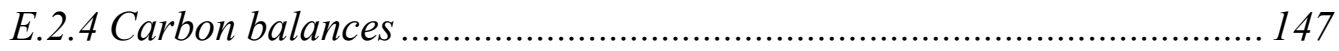

APPENDIX F: Thermodynamic Analysis of Kinetic Data for $\mathrm{CO}_{2}$ Reforming of

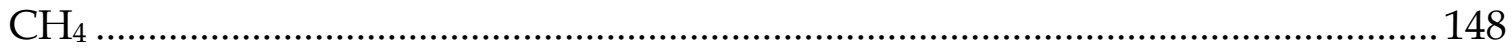

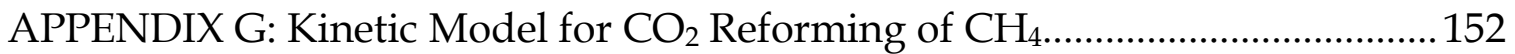




\section{LIST OF FIGURES}

Figure 2.1. Temperature dependence of standard Gibbs free energy for various reactions in the $\mathrm{CH}_{4} / \mathrm{CO}_{2}$ reforming system............................................................ 8

Figure 3.1. Flowsheet of the catalyst-testing unit. ............................................... 35

Figure 3.2. Schematic flow diagram of two position six-port external volume sample injector (Valco Instruments Co. Inc.) .......................................................... 36

Figure 4.1 Effect of reaction temperatures cycles on $\mathrm{CH}_{4}$ conversion over $\mathrm{Ni} / \mathrm{Al}_{2} \mathrm{O}_{3}$ catalyst. (Particle size 90-125 $\mu \mathrm{m}, \mathrm{CH}_{4} / \mathrm{CO}_{2} / \mathrm{Ar}=1 / 3.7 / 4.9$, total feed rate: 170 $\mathrm{scc} / \mathrm{min})$

Figure 4.2 Effect of reaction temperatures cycles on $\mathrm{CO}_{2}$ conversion over $\mathrm{Ni} / \mathrm{Al}_{2} \mathrm{O}_{3}$ catalyst. (Particle size 90-125 $\mu \mathrm{m}, \mathrm{CH}_{4} / \mathrm{CO}_{2} / \mathrm{Ar}=1 / 3.7 / 4.9$, total feed rate: 170 $\mathrm{scc} / \mathrm{min})$

Figure 4.3 Effect of reaction temperatures on the activity over $\mathrm{Ni} / \mathrm{Al}_{2} \mathrm{O}_{3}$ catalyst. (Particle size $300-600 \mu \mathrm{m}, \mathrm{CH}_{4} / \mathrm{CO}_{2} / \mathrm{Ar}=1 / 3.7 / 4.9$, total feed rate: $170 \mathrm{scc} / \mathrm{min}$ ) 47

Figure 4.4 Effect of reaction temperatures on the activity over $\mathrm{Ni} / \mathrm{Al}_{2} \mathrm{O}_{3}$ catalyst. (Particle size $90-125 \mu \mathrm{m}, \mathrm{CH}_{4} / \mathrm{CO}_{2} / \mathrm{Ar}=1 / 3.7 / 4.9$, total feed rate: $170 \mathrm{scc} / \mathrm{min}$ )

Figure 4.5 Arrhenius plots for initial Ni/A12O3 activity for $\mathrm{CH} 4 / \mathrm{CO} 2$ reforming. $(\bullet) \mathrm{CH}_{4}$ consumption; $(\mathrm{O}) \mathrm{CO}_{2}$ consumption; $(\diamond) \mathrm{CO}$ production; $(\diamond) \mathrm{H}_{2}$ production; $(\Delta)$ $\mathrm{H}_{2} \mathrm{O}$ production. (Particle size $300-600 \mu \mathrm{m}, \mathrm{CH} 4 / \mathrm{CO} 2 / \mathrm{Ar}=1 / 3.7 / 4.9$, total feed rate: $170 \mathrm{scc} / \mathrm{min})$.

Figure 4.6 Deactivation of the $\mathrm{Pt} / \mathrm{ZrO}_{2}$ catalyst for $\mathrm{CH}_{4} / \mathrm{CO}_{2}$ reforming.

Figure 5.1 Effect of increasing and decreasing reaction temperature cycles on $\mathrm{CH}_{4}$ conversion over $\mathrm{Co}_{6} \mathrm{~W}_{6} \mathrm{C}$ catalyst at different total pressures. (Particle size 90-125 $\mu \mathrm{m}, \mathrm{CH}_{4} / \mathrm{CO}_{2} / \mathrm{Ar}=1 / 1 /(\mathrm{x}-2)$, where $\mathrm{x}=\mathrm{P}_{\text {total }}$ in atm.)

Figure 5.2 Effect of the number of reaction temperature cycles on $\mathrm{CH}_{4}$ conversion over $\mathrm{Co}_{6} \mathrm{~W}_{6} \mathrm{C}$ catalyst. (Particle size $90-125 \mu \mathrm{m}, \mathrm{CH}_{4} / \mathrm{CO}_{2} / \mathrm{Ar}=1 / 1 / 1, \mathrm{P}_{\text {total }}=3 \mathrm{~atm}$.) .... 59

Figure 5.3 Effect of increasing and decreasing reaction temperature cycles on $\mathrm{CO}_{2}$ conversion over $\mathrm{Co}_{6} \mathrm{~W}_{6} \mathrm{C}$ catalyst at different total pressures. (Particle size 90-125 $\mu \mathrm{m}, \mathrm{CH}_{4} / \mathrm{CO}_{2} / \mathrm{Ar}=1 / 1 /(\mathrm{x}-2)$, where $\mathrm{x}=\mathrm{P}_{\text {total }}$ in atm.)

Figure 5.4 Effect of the number of reaction temperature cycles on $\mathrm{CO}_{2}$ conversion over $\mathrm{Co}_{6} \mathrm{~W}_{6} \mathrm{C}$ catalyst. (Particle size $90-125 \mu \mathrm{m}, \mathrm{CH}_{4} / \mathrm{CO}_{2} / \mathrm{Ar}=1 / 1 / 1, \mathrm{P}_{\text {total }}=3 \mathrm{~atm}$.) ... 60 
Figure 5.5 Effect of reaction temperature cycles on $\mathrm{CH}_{4}$ conversion over $\mathrm{Co}_{6} \mathrm{~W}_{6} \mathrm{C}$ catalyst. (All reactants and inerts are in the same cylinder. Particle size $<38 \mu \mathrm{m}$, $\mathrm{CH}_{4} / \mathrm{CO}_{2} / \mathrm{Ar}=1 / 1 / 1.4, \mathrm{P}_{\text {total }}=3.4 \mathrm{~atm}$.)

Figure 5.6 Effect of reaction temperature cycles on $\mathrm{CO}_{2}$ conversion over $\mathrm{Co}_{6} \mathrm{~W}_{6} \mathrm{C}$ catalyst. (All reactants and inerts are in the same cylinder. Particle size $<38 \mu \mathrm{m}$, $\mathrm{CH}_{4} / \mathrm{CO}_{2} / \mathrm{Ar}=1 / 1 / 1.4, \mathrm{P}_{\text {total }}=3.4 \mathrm{~atm}$. $)$

Figure 5.7 Effect of reaction temperatures on $\mathrm{H}_{2} / \mathrm{CO}$ ratio for $\mathrm{CO}_{2}$ reforming of $\mathrm{CH}_{4}$ with $\mathrm{Co}_{6} \mathrm{~W}_{6} \mathrm{C}$ catalyst. (Particle size $90-125 \mu \mathrm{m}, \mathrm{CH}_{4} / \mathrm{CO}_{2} / \mathrm{Ar}=1 / 1 / 1, \mathrm{P}_{\text {total }}=3 \mathrm{~atm}$.) .... 63

Figure 5.8 Effect of reaction temperatures on $\mathrm{H}_{2} / \mathrm{CO}$ ratio for $\mathrm{CO}_{2}$ reforming of $\mathrm{CH}_{4}$ with $\mathrm{Co}_{6} \mathrm{~W}_{6} \mathrm{C}$ catalyst. (Particle size $<38 \mu \mathrm{m}, \mathrm{CH}_{4} / \mathrm{CO}_{2} / \mathrm{Ar}=1 / 1 / 1.4, \mathrm{P}_{\text {total }}=3.4 \mathrm{~atm}$.). .64

Figure 5.9 Effect of reaction temperatures on the activity of the silica lined blank reactor for $\mathrm{CO}_{2}$ reforming of $\mathrm{CH}_{4}\left(\mathrm{CH}_{4} / \mathrm{CO}_{2} / \mathrm{Ar}=1 / 1 / 3, \mathrm{P}_{\text {total }}=5 \mathrm{~atm}\right.$. $)$

Figure 5.10 Effect of reaction temperatures on the rates of formation of different species in the silica lined blank reactor for the $\mathrm{CO}_{2}$ reforming of $\mathrm{CH}_{4}\left(\mathrm{CH}_{4} / \mathrm{CO}_{2} / \mathrm{Ar}=1 / 1 / 3\right.$, $\mathrm{P}_{\text {total }}=5 \mathrm{~atm}$.)

Figure 5.11 Conversions during the lifetime study of the $\mathrm{Co}_{6} \mathrm{~W}_{6} \mathrm{C}$ catalyst for the $\mathrm{CO}_{2}$ reforming of $\mathrm{CH}_{4}\left(\mathrm{~T}=850{ }^{\circ} \mathrm{C}\right.$, particle size $<38 \mu \mathrm{m}, \mathrm{CH}_{4} / \mathrm{CO}_{2} / \mathrm{Ar}=1 / 1 / 3, \mathrm{P}_{\text {total }}=5$ atm., reactant WHSV $\left.=4250 \mathrm{scc} / \mathrm{hr} / \mathrm{g}_{\text {catalyst }}\right)$....

Figure 5.12 $\mathrm{CO}$ yields and product selectivity during the lifetime study of the $\mathrm{Co}_{6} \mathrm{~W}_{6} \mathrm{C}$ catalyst for the $\mathrm{CO}_{2}$ reforming of $\mathrm{CH}_{4}\left(\mathrm{~T}=850{ }^{\circ} \mathrm{C}\right.$, particle size $<38 \mu \mathrm{m}$, $\mathrm{CH}_{4} / \mathrm{CO}_{2} / \mathrm{Ar}=1 / 1 / 3, \mathrm{P}_{\text {total }}=5 \mathrm{~atm}$. , reactant $\left.\mathrm{WHSV}=4250 \mathrm{scc} / \mathrm{hr} / \mathrm{g}_{\text {catalyst }}\right)$.

Figure 5.13 Effect of reaction temperature on the $\mathrm{Co}_{6} \mathrm{~W}_{6} \mathrm{C}$ catalyst activity for the $\mathrm{CO}_{2}$ reforming of $\mathrm{CH}_{4}$ (Particle size $<38 \mu \mathrm{m}, \mathrm{CH}_{4} / \mathrm{CO}_{2} / \mathrm{Ar}=1 / 1 / 3, \mathrm{P}_{\text {total }}=5 \mathrm{~atm}$, reactant $\left.\mathrm{WHSV}=4250 \mathrm{scc} / \mathrm{hr} / \mathrm{g}_{\text {catalyst }}\right)$.....

Figure 5.14 Effect of reaction temperature on the rates of formation of different reaction species for the $\mathrm{CO}_{2}$ reforming of $\mathrm{CH}_{4}$ with $\mathrm{Co}_{6} \mathrm{~W}_{6} \mathrm{C}$ catalyst (Particle size $<38 \mu \mathrm{m}$, $\mathrm{CH}_{4} / \mathrm{CO}_{2} / \mathrm{Ar}=1 / 1 / 3, \mathrm{P}_{\text {total }}=5 \mathrm{~atm}$, reactant $\mathrm{WHSV}=4250 \mathrm{scc} / \mathrm{hr} / \mathrm{g}_{\text {catalyst }}, \Delta \mathrm{CD}$ is the net carbon deposition as given by a carbon balance)

Figure 5.15 Arrhenius plots for initial $\mathrm{Co}_{6} \mathrm{~W}_{6} \mathrm{C}$ activity for $\mathrm{CH}_{4} / \mathrm{CO}_{2}$ reforming. (•) $\mathrm{CH}_{4}$ consumption; (O) $\mathrm{H}_{2}$ production; ( $\bullet$ CO production; $(\Delta) \mathrm{H}_{2} \mathrm{O}$ production. (Particle size $<38 \mu \mathrm{m}, \mathrm{CH}_{4} / \mathrm{CO}_{2} / \mathrm{Ar}=1 / 1 / 3, \mathrm{P}_{\text {total }}=5$ atm., reactant $\mathrm{WHSV}=4250$ $\mathrm{scc} / \mathrm{hr} / \mathrm{g}_{\text {catalyst }}$. 
Figure 5.16 XRD patterns of: (a) fresh $\mathrm{Co}_{6} \mathrm{~W}_{6} \mathrm{C}$ catalyst and (b) after stabilization; during $\mathrm{CH}_{4} / \mathrm{CO}_{2}$ reforming at $850^{\circ} \mathrm{C}$. (Particle size $<38 \mu \mathrm{m}, \mathrm{CH}_{4} / \mathrm{CO}_{2} / \mathrm{Ar}=1 / 1 / 3, \mathrm{P}_{\text {total }}=$ $5 \mathrm{~atm}$. , reactant $\mathrm{WHSV}=4250 \mathrm{scc} / \mathrm{hr} / \mathrm{g}_{\text {catalyst }}$ )

Figure 5.17 Ternary phase diagram of cobalt-tungsten-carbon (isothermal section at 1400

K), (Polizzotti et al., 1994).

Figure $5.18 \mathrm{XRD}$ pattern of $\mathrm{Co}_{6} \mathrm{~W}_{6} \mathrm{C}$ catalyst when exposed to ambient pressure after $\mathrm{CH}_{4} / \mathrm{CO}_{2}$ reforming. 78

Figure 5.19 SEM images of the carbon deposits on the Co-WC catalyst after the $\mathrm{CH}_{4} / \mathrm{CO}_{2}$ reforming at $850^{\circ} \mathrm{C}\left(\mathrm{CH}_{4} / \mathrm{CO}_{2} / \mathrm{Ar}=1 / 1 / 3, \mathrm{P}_{\text {total }}=5 \mathrm{~atm}\right.$. $)$

Figure 6.1 Effect of reactant partial pressures on the rates of formation of different reaction species for the $\mathrm{CO}_{2}$ reforming of $\mathrm{CH}_{4}$ with $\mathrm{Co}_{6} \mathrm{~W}_{6} \mathrm{C}$ catalyst $\left(\mathrm{T}=600{ }^{\circ} \mathrm{C}\right.$, Particle size $<38 \mu \mathrm{m}$, Total feed WHSV $=11,200 \mathrm{scc} / \mathrm{hr} /$ g-catalyst., $\mathrm{P}_{\text {total }}=5 \mathrm{~atm}$.) Lines denote the LH model as given in section 6.3.4.

Figure 6.2 Effect of reactant partial pressures on the rates of formation of different reaction species for the $\mathrm{CO}_{2}$ reforming of $\mathrm{CH}_{4}$ with $\mathrm{Co}_{6} \mathrm{~W}_{6} \mathrm{C}$ catalyst $\left(\mathrm{T}=550{ }^{\circ} \mathrm{C}\right.$, Particle size $<38 \mu \mathrm{m}$, Total feed WHSV $=11,200 \mathrm{scc} / \mathrm{hr} /$ g-catalyst., $\mathrm{P}_{\text {total }}=5 \mathrm{~atm}$.) Lines denote the LH model as given in section 6.3.4.

Figure 6.3 Effect of reactant partial pressures on the rates of formation of different reaction species for the $\mathrm{CO}_{2}$ reforming of $\mathrm{CH}_{4}$ with $\mathrm{Co}_{6} \mathrm{~W}_{6} \mathrm{C}$ catalyst $\left(\mathrm{T}=500{ }^{\circ} \mathrm{C}\right.$, Particle size $<38 \mu \mathrm{m}$, Total feed WHSV $=11,200 \mathrm{scc} / \mathrm{hr} /$ g-catalyst., $\mathrm{P}_{\text {total }}=5 \mathrm{~atm}$.) Lines denote the LH model as given in section 6.3.4.

Figure 6.4 Effect of reaction temperatures and reactant partial pressures on the rates of formation of $\mathrm{CO}$ for the $\mathrm{CO}_{2}$ reforming of $\mathrm{CH}_{4}$ with $\mathrm{Co}_{6} \mathrm{~W}_{6} \mathrm{C}$ catalyst (Particle size $<38 \mu \mathrm{m}$, Total feed WHSV $=11,200 \mathrm{scc} / \mathrm{hr} / \mathrm{g}$-catalyst., $\mathrm{P}_{\text {total }}=5 \mathrm{~atm}$.) Lines denote the LH model as given in section 6.3.4.

Figure 6.5 Effect of reaction temperatures and reactant partial pressures on the rates of formation of $\mathrm{H}_{2}$ for the $\mathrm{CO}_{2}$ reforming of $\mathrm{CH}_{4}$ with $\mathrm{Co}_{6} \mathrm{~W}_{6} \mathrm{C}$ catalyst (Particle size $<$ $38 \mu \mathrm{m}$, Total feed WHSV $=11,200 \mathrm{scc} / \mathrm{hr} / \mathrm{g}$-catalyst., $\mathrm{P}_{\text {total }}=5 \mathrm{~atm}$.) Lines denote the LH model as given in section 6.3.4.....

Figure 6.6 Effect of reaction temperatures and reactant partial pressures on the rates of formation of $\mathrm{H}_{2} \mathrm{O}$ for the $\mathrm{CO}_{2}$ reforming of $\mathrm{CH}_{4}$ with $\mathrm{Co}_{6} \mathrm{~W}_{6} \mathrm{C}$ catalyst (Particle size $<38 \mu \mathrm{m}$, Total feed WHSV $=11,200 \mathrm{scc} / \mathrm{hr} / \mathrm{g}$-catalyst., $\mathrm{P}_{\text {total }}=5 \mathrm{~atm}$.) Lines denote the LH model as given in section 6.3.4.

Figure 6.7 Extent of reaction equilibrium as a function of temperature for the $\mathrm{CO}_{2}$ reforming of $\mathrm{CH}_{4}$ with $\mathrm{Co}_{6} \mathrm{~W}_{6} \mathrm{C}$ catalyst (Particle size $<38 \mu \mathrm{m}, \mathrm{CH}_{4} / \mathrm{CO}_{2} / \mathrm{Ar}=$ $\left.1 / 1 / 3, P_{\text {total }}=5 \mathrm{~atm}, \mathrm{P}_{\text {ref }}=1 \mathrm{~atm}\right)$. 
Figure 6.8 Comparison of predicted and observed rates of formation of different reaction species for increasing reactant partial pressures during $\mathrm{CH}_{4} / \mathrm{CO}_{2}$ reforming with $\mathrm{Co}_{6} \mathrm{~W}_{6} \mathrm{C}$ catalyst. $\left(\mathrm{T}=600{ }^{\circ} \mathrm{C}\right.$, Particle size $<38 \mu \mathrm{m}$, Total feed $\mathrm{WHSV}=11,200$ $\mathrm{scc} / \mathrm{hr} /$ g-catalyst., $\mathrm{P}_{\text {total }}=5 \mathrm{~atm}$.) Lines denote the power-law model.

Figure 6.9 Comparison of predicted and observed rates of formation of different reaction species for increasing reactant partial pressures during $\mathrm{CH}_{4} / \mathrm{CO}_{2}$ reforming with $\mathrm{Co}_{6} \mathrm{~W}_{6} \mathrm{C}$ catalyst. $\left(\mathrm{T}=550{ }^{\circ} \mathrm{C}\right.$, Particle size $<38 \mu \mathrm{m}$, Total feed $\mathrm{WHSV}=11,200$ $\mathrm{scc} / \mathrm{hr} / \mathrm{g}$-catalyst., $\mathrm{P}_{\text {total }}=5 \mathrm{~atm}$.) Lines denote the power-law model

Figure 6.10 Comparison of predicted and observed rates of formation of different reaction species for increasing reactant partial pressures during $\mathrm{CH}_{4} / \mathrm{CO}_{2}$ reforming with $\mathrm{Co}_{6} \mathrm{~W}_{6} \mathrm{C}$ catalyst. $\left(\mathrm{T}=500{ }^{\circ} \mathrm{C}\right.$, Particle size $<38 \mu \mathrm{m}$, Total feed WHSV $=$ $11,200 \mathrm{scc} / \mathrm{hr} / \mathrm{g}$-catalyst., $\mathrm{P}_{\text {total }}=5 \mathrm{~atm}$.) Lines denote the power-law model.

Figure 6.11 Comparison plot for the net rates of $\mathrm{H}_{2}$ formation 103

Figure 6.12 Comparison plot for the net rates of $\mathrm{CO}$ formation ...... 103

Figure 6.13 Comparison plot for the net rates of $\mathrm{H}_{2} \mathrm{O}$ formation 104

Figure 6.14 Comparison plot for the net rates of formation for each of the species.....

Figure 6.15 Comparison plot for the net rates of $\mathrm{H}_{2}$ formation

Figure 6.16 Comparison plot for the net rates of $\mathrm{CO}$ formation

Figure 6.17 Comparison plot for the net rates of $\mathrm{H}_{2} \mathrm{O}$ formation

Figure A.1 A typical chromatogram showing separation of different species for $\mathrm{CO}_{2}$ reforming of $\mathrm{CH}_{4}$. Obtained using $\mathrm{Ni} / \mathrm{Al}_{2} \mathrm{O}_{3}$ catalyst (120-170 mesh size), $\mathrm{T}=700$ $\mathrm{oC}$; feed ratio $=\mathrm{CH}_{4}: \mathrm{CO}_{2}: \mathrm{Ar}=1: 3.7: 4.9$.

Figure B.1 GC calibration curve for $\mathrm{H}_{2} \mathrm{O}$

Figure B.2 GC calibration curve for He

Figure B.3 GC calibration curve for $\mathrm{CH}_{4}$

Figure B.4 GC calibration curve for $\mathrm{H}_{2}$

Figure B.5 GC calibration curve for $\mathrm{CO}$.

Figure B.6 GC calibration curve for $\mathrm{CO}_{2}$ 133

Figure C.1 MFC calibration curve for $\mathrm{CH}_{4} / \mathrm{He}$ mixture. 136 


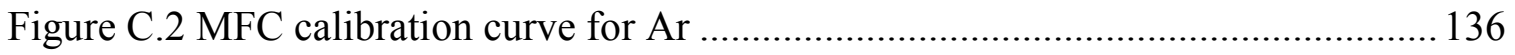

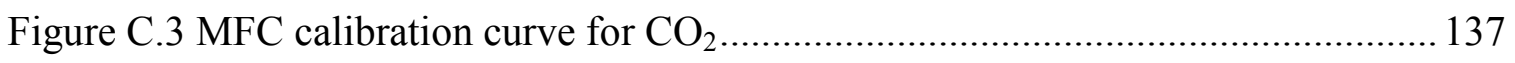

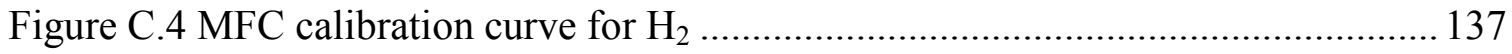

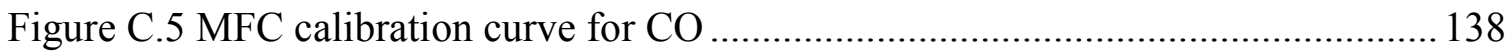




\section{LIST OF TABLES}

Table 2.1. Compilation of various catalyst systems investigated used for dry reforming (Bradford and Vannice, 1999; Wang et al., 1996) ..................................................... 11

Table 2.2. Effect of support on the catalyst activity (Wang et al., 1996) ........................ 12

Table 2.3. Methane dry reforming over carbide, Ni-based and noble-metal catalysts

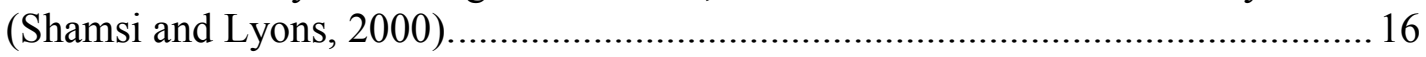

Table 2.4. Methane dry reforming over metal carbide catalysts (Claridge et al., 1998). . 17

Table 2.5. Combined steam and dry reforming over metal carbide catalysts $(\mathrm{T}=1170 \mathrm{~K}, \mathrm{P}$ $\left.=8.7 \mathrm{bar}, \mathrm{GHSV}=5.2 \times 10^{3} \mathrm{~h}^{-1}, \mathrm{CH}_{4}: \mathrm{CO}_{2}: \mathrm{H}_{2} \mathrm{O}=3: 1: 2\right)($ Claridge et al, 1998). 17

Table 2.6. Parameters of the power law equation (Wang et al. 1996) .............................. 19

Table 2.7 Proposed rate expressions for dry reforming of methane with carbon dioxide. 29

Table 4.1. Activation energies for the $\mathrm{CO}_{2}$ reforming of $\mathrm{CH}_{4}$ over $\mathrm{Ni} / \mathrm{Al}_{2} \mathrm{O}_{3}$ catalyst ..... 49

Table 4.2. Activation energies for the $\mathrm{CO}_{2}$ reforming of $\mathrm{CH}_{4}$ over supported Ni catalysts.

Table 4.3. Experimental details for the $\mathrm{CO}_{2}$ reforming of $\mathrm{CH}_{4}$ over $\mathrm{Pt} / \mathrm{ZrO}_{2}$ catalyst..... 53

Table 5.1. Summary of catalyst activity for various carbide catalysts for $\mathrm{CO}_{2}$ reforming of $\mathrm{CH}_{4}$ with a $1: 1$ feed ratio.

Table 5.2. Activation energies for the $\mathrm{CO}_{2}$ reforming of $\mathrm{CH}_{4}$ over various catalyst systems

Table 6.1 Experimental design for the kinetic study of the $\mathrm{CO}_{2}$ reforming of $\mathrm{CH}_{4}$ with $\mathrm{Co}_{6} \mathrm{~W}_{6} \mathrm{C}$ catalyst (Particle size $<38 \mu \mathrm{m}$, weight of catalyst used $=0.3 \mathrm{~g}$, Total feed $\mathrm{WHSV}=11,200 \mathrm{scc} / \mathrm{hr} / \mathrm{g}$-catalyst., $\mathrm{P}_{\text {total }}=5 \mathrm{~atm}$.)

Table 6.2 Partial pressure data at reactor outlet for the kinetic study of the $\mathrm{CO}_{2}$ reforming of $\mathrm{CH}_{4}$ (Particle size $<38 \mu \mathrm{m}$, weight of catalyst used $=0.3 \mathrm{~g}$, Total feed WHSV $=$ $11,200 \mathrm{scc} / \mathrm{hr} /$ g-catalyst., $\mathrm{P}_{\text {total }}=5 \mathrm{~atm}$.)

Table 6.3 Rates of production of the reaction products for the kinetic study of the $\mathrm{CO}_{2}$ reforming of $\mathrm{CH}_{4}$ (Particle size $<38 \mu \mathrm{m}$, weight of catalyst used $=0.3 \mathrm{~g}$, Total feed

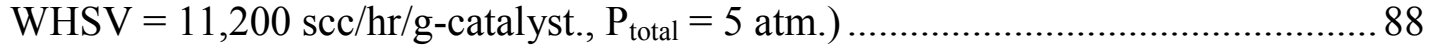

Table 6.4. Parameter estimates of the Power Law model .99 
Table 6.5 Parameter estimates for the Langmuir Hinshelwood (LH) model

Table F.1 Observed equilibrium ratios and predicted equilibrium constants $\left(\mathrm{K}_{\mathrm{a}}\right)$ during the kinetic study of the $\mathrm{CO}_{2}$ reforming of $\mathrm{CH}_{4}$ (Particle size $<38 \mu \mathrm{m}$, weight of catalyst used $=0.3 \mathrm{~g}$, Total feed WHSV $=11,200 \mathrm{scc} / \mathrm{hr} / \mathrm{g}$-catalyst., $P_{\text {total }}=5 \mathrm{~atm}$.) 


\section{CHAPTER 1}

\section{INTRODUCTION}

The reserves of the dominant fossil fuel, crude oil, throughout the world are fast depleting. Natural gas, defined as a combustible gas that occurs in porous rock of the earth's crust, is found with or near the crude oil reserves. Methane is a major component of natural gas, with a fraction of 70 to $98 \%$, depending on the location where it is obtained (Ross et al., 1996). Natural gas is an abundant fossil fuel found all over the world and its reserves are expected to surpass those of crude oil by a considerable margin (Otsuka et al., 1993). Hence, natural gas would play a significant role as a carbon source for the world's supply of fuel and fuel-based chemicals in this century.

It has been found that most of the world's natural gas reserves are situated in remote areas and are not easily accessible from the areas of high-energy consumption. To improve the viability of methane consumption, research is carried out into the conversion of methane to liquids or higher hydrocarbons. There have been studies on direct oxidative conversions of methane into methanol, formaldehyde, propanal, benzene and other aromatics (Claridge et al. 1998); also direct oxidative coupling of methane to ethane and ethylene. But all these processes either demonstrate low yields or are not economically viable, not able to meet industrial requirements at the existing price of crude oil (Claridge et al. 1998). Existing industrial processes make use of methane as a primary feedstock for conversion to a mixture of carbon monoxide and hydrogen (synthesis gas or syngas). In fact, the cost of syngas production in converting natural gas to liquid fuels can be more than $60 \%$ of the total cost. Hence, reducing the cost of syngas 
would play a significant role in the economics of the gas-to-liquids process (Ross et al., 1996, Rostrup-Nielsen and Hansen, 1993). The syngas produced serves as the feedstock in a variety of downstream processes, such as methanol synthesis, Fischer-Tropsch synthesis or ammonia synthesis.

\subsection{Reforming}

Reforming of methane to syngas can be carried out in three different ways (Claridge et al., 1998):

1. The conventional steam (or wet) reforming using steam (or water),

$$
\mathrm{CH}_{4}+\mathrm{H}_{2} \mathrm{O} \longleftrightarrow \mathrm{CO}+3 \mathrm{H}_{2} \quad(\Delta \mathrm{H}=+206 \mathrm{~kJ} / \mathrm{mol}) \text {----- ( 1.1) }
$$

2. Dry reforming using carbon dioxide,

$$
\mathrm{CH}_{4}+\mathrm{CO}_{2} \longleftrightarrow 2 \mathrm{CO}+2 \mathrm{H}_{2} \quad(\Delta \mathrm{H}=+247 \mathrm{~kJ} / \mathrm{mol})----(1.2)
$$

3. Partial oxidation using oxygen,

$$
\mathrm{CH}_{4}+\frac{1}{2} \mathrm{O}_{2} \rightleftarrows \mathrm{CO}+2 \mathrm{H}_{2} \quad(\Delta \mathrm{H}=-38 \mathrm{~kJ} / \mathrm{mol})
$$

\subsection{Significance of dry reforming}

In recent years, there has been considerable interest in the area of greenhouse gases due to the alarming global warming effect. Methane and carbon dioxide are both greenhouse gases. Therefore, the reduction and use of these gases would be very much appreciated and is gaining more importance (Wang et al., 1996). Catalytic reforming of

methane with carbon dioxide to syngas has been proposed as one of the most promising 
technologies for use of these greenhouse gases as carbon-containing materials. Syngas produced by dry reforming has a higher purity as compared to the conventional steam reforming process. Dry reforming also results in a lower $\mathrm{H}_{2} / \mathrm{CO}$ ratio, near unity (Bradford and Vannice, 1999). (Typically, steam reforming produces syngas with a $\mathrm{H}_{2} / \mathrm{CO}$ ratio of 3 while partial oxidation can yield a ratio close to 2.) In the case of certain applications (like Fischer-Tropsch synthesis of long-chain hydrocarbons, hydroformylation, and synthesis of valuable oxygenated chemicals such as oxo-alcohols), a $\mathrm{H}_{2} / \mathrm{CO}$ feed ratio close to unity is desired. Further, carbon dioxide is also a significant component of natural gas at many locations, and dry reforming can be especially useful in those remote gas fields where there is an abundance of $\mathrm{CO}_{2}$. Finally, this process can be employed in those remote gas fields where water is not easily available.

The steam-reforming process has higher operating pressures. This might lead to higher operating expenses. Thus, reducing operating pressures by the dry-reforming process would trim down both operating expenses and equipment costs, improving plant safety. Ross et al. (1996) have shown that dry reforming has the lowest operating costs, about $20 \%$ lower than any other reforming processes. Finally, $\mathrm{CH}_{4}$ and $\mathrm{CO}_{2}$ are both inexpensive owing to their natural abundance and therefore their conversion to highervalue compounds is of considerable interest.

\subsection{Need for new catalysts}

Commercially, nickel-based catalysts are used for methane reforming due to their inherent availability and low costs as compared to the noble metals. However, these nickel catalysts also catalyze coke formation via methane decomposition 


$$
\mathrm{CH}_{4} \longleftrightarrow 2 \mathrm{H}_{2}+\mathrm{C}_{(\mathrm{s})} \quad(\Delta \mathrm{H}=+75 \mathrm{~kJ} / \mathrm{mol})
$$

and $\mathrm{CO}$ disproportionation (Boudouard reaction)

$$
2 \mathrm{CO} \rightleftarrows \mathrm{CO}_{2}+\mathrm{C}_{(\mathrm{s})} \quad(\Delta \mathrm{H}=-172 \mathrm{~kJ} / \mathrm{mol})
$$

Coke leads to deactivation of the catalysts and plugging of reformer tubes by carbon deposits, and is one of the major problems associated with dry reforming (Seshan et al., 1994). One possible solution could be addition of excess oxidants in order to suppress the coke deposition. However, this increases the $\mathrm{CO}_{2} / \mathrm{CO}$ ratio, which defeats the basic purpose of dry reforming. Hence, notable efforts have been concentrated on exploring new catalysts, which are resistant to carbon formation. Sulfur-passivated nickel catalysts and noble-metal catalysts have been shown to exhibit resistance to carbon formation (Rostrup-Nielsen and Hansen, 1993). But the low activity of sulfur-passivated nickel catalysts, and the high costs as well as limited availability of noble metals, have limited their potential applications.

There has been considerable interest in the catalytic properties of metal carbides. Metal carbides are abundant and their price is cheap compared to noble metals. It has been suggested that metal carbides can replace the rare and expensive noble metals in catalysis (York, 1999). Exploring better catalysts would reduce process costs for methanol, ammonia, and Fischer-Tropsch plants. There has been increasing evidence that carbides of molybdenum and tungsten could serve as potential future alternatives to the platinum-group metal catalysts and are being identified as "magic catalysts" for this millennium (York, 1999). 


\subsection{Objectives of this study}

The overall purpose of this research study is to investigate new molybdenum or tungsten carbide catalysts for dry reforming of methane to produce syngas. Some of the initial objectives of this project were to optimize the operational conditions of the catalyst-testing unit to be used in this study. For this purpose, a commercial Ni/ $\mathrm{Al}_{2} \mathrm{O}_{3}$ catalyst obtained from United Catalyst. Inc. was tested. Studies also included preparation and testing of $\mathrm{Pt} / \mathrm{ZrO}_{2}$ catalyst.

The main scope of this project includes:

- Inspecting the catalytic performance of a cobalt tungsten carbide material $\left[\mathrm{Co}_{6} \mathrm{~W}_{6} \mathrm{C}\right]$ obtained from Nanodyne Inc., for the dry reforming reactions.

- Investigating the catalyst activity for various particle sizes, pretreatment conditions, reaction temperatures, gas feed rates and feed ratios.

- Characterizing the fresh and used catalyst by X-ray diffraction studies in order to comprehend the various structural/phase changes taking place.

- Performing the modeling and kinetic studies for the tungsten carbide catalyst. 


\section{CHAPTER 2}

\section{LITERATURE REVIEW}

Although research into the $\mathrm{CO}_{2}$ reforming of natural gas had been initiated in the 1920 s, it is only recently that it has gained renewed interest because of the potential applications in the greenhouse chemistry (Ross et al., 1996). As discussed earlier, the focus is on the applications of the carbide catalysts for this process, with some insight into the wide range of noble and transition metal catalysts already studied in detail.

\subsection{Overview}

As seen earlier, the existing major source of syngas comes from steam reforming of methane. But this process has its own limitations, such as high energy requirements. In the partial oxidation technique, some of these limitations can be overcome, but it has its own set of disadvantages viz. operating at very high temperatures and pressures without catalysts. Therefore, dry reforming using $\mathrm{CO}_{2}$ seems to be a very promising alternative. Fischer and Tropsch first proposed this reaction in 1928 (Wang et al., 1996) and it has several advantages. So far, there is no commercially well-established $\mathrm{CO}_{2}$ reforming process due to the perennial coking problem, although Teuner (1985) has reported a commercial Calcor process for the $\mathrm{CO}_{2}$ reforming of hydrocarbons to yield synthesis gas over an unspecified catalyst. Fujimoto et al. (1992) have reported a twostage reactor process for the synthesis of liquid hydrocarbons from dry reforming and 
Fischer Tropsch reactions. Therefore, dry reforming seems very promising, provided the problem of coking, and hence catalyst deactivation, is taken care of.

\subsection{Thermodynamics of $\mathrm{CO}_{2}$ reforming of methane}

The temperature dependence of the standard Gibbs free energy for dry reforming (eqn.1.2) is given by (Wang et al., 1996):

$$
\Delta \mathrm{G}^{0}=61770-67.32 \mathrm{~T} \quad \mathrm{cal} / \mathrm{mol} \text { where } \mathrm{T} \text { is in }[\mathrm{K}]
$$

This is the main reaction occurring and is highly endothermic. It is favored by low pressure but requires a higher temperature and is typically influenced by the simultaneous occurrence of the reverse water-gas shift reaction (RWGS):

$$
\begin{aligned}
& \mathrm{CO}_{2}+\mathrm{H}_{2} \longrightarrow \mathrm{CO}+\mathrm{H}_{2} \mathrm{O} \quad\left(\Delta \mathrm{H}_{298}=41 \mathrm{~kJ} / \mathrm{mol}\right) \\
& \Delta \mathrm{G}^{0}=-8545+7.84 \mathrm{~T} \quad \mathrm{cal} / \mathrm{mol} \quad \text { where } \mathrm{T} \text { is in }[\mathrm{K}]
\end{aligned}
$$

as one of the side reactions. RWGS is predominant at times, depending on the $\mathrm{CH}_{4} / \mathrm{CO}_{2}$ feed ratios. The simultaneous occurrence of both reactions results in a $\mathrm{H}_{2} / \mathrm{CO}$ ratio of less than unity and a $\mathrm{CO}_{2}$ conversion which is generally greater than that of $\mathrm{CH}_{4}$. Other reactions that can take place are the carbon deposition reactions of $\mathrm{CO}$ disproportionation, the Boudouard reaction (eqn. 1.5), with

$$
\Delta \mathrm{G}^{0}=-39810+40.87 \mathrm{~T} \quad \mathrm{cal} / \mathrm{mol} \text { where } \mathrm{T} \text { is in }[\mathrm{K}]------(2.4)
$$

and methane decomposition (eqn. 1.4) with

$$
\Delta \mathrm{G}^{0}=21960-26.45 \mathrm{~T} \quad \mathrm{cal} / \mathrm{mol} \text { where } \mathrm{T} \text { is in }[\mathrm{K}] \quad \text {------ (2.5) }
$$


Besides these reactions, there could be other side reactions, such as the formation of higher hydrocarbons or other unsaturated products, which might be taking place in very insignificant proportions and are typically not accounted for in the analysis.

Based on eqns (2.1) and (2.3) through (2.5), as reported by Wang et al. (1996), the standard Gibbs free energy change can be obtained for a given temperature range, for each of the four reactions, and is as given in Figure 2.1. It can be inferred from Figure 2.1. that, the reforming reaction as well as the $\mathrm{CH}_{4}$ decomposition reaction are favorable for increasing reaction temperatures. However, the RWGS as well as the Boudouard reactions are favorable for decreasing temperatures.

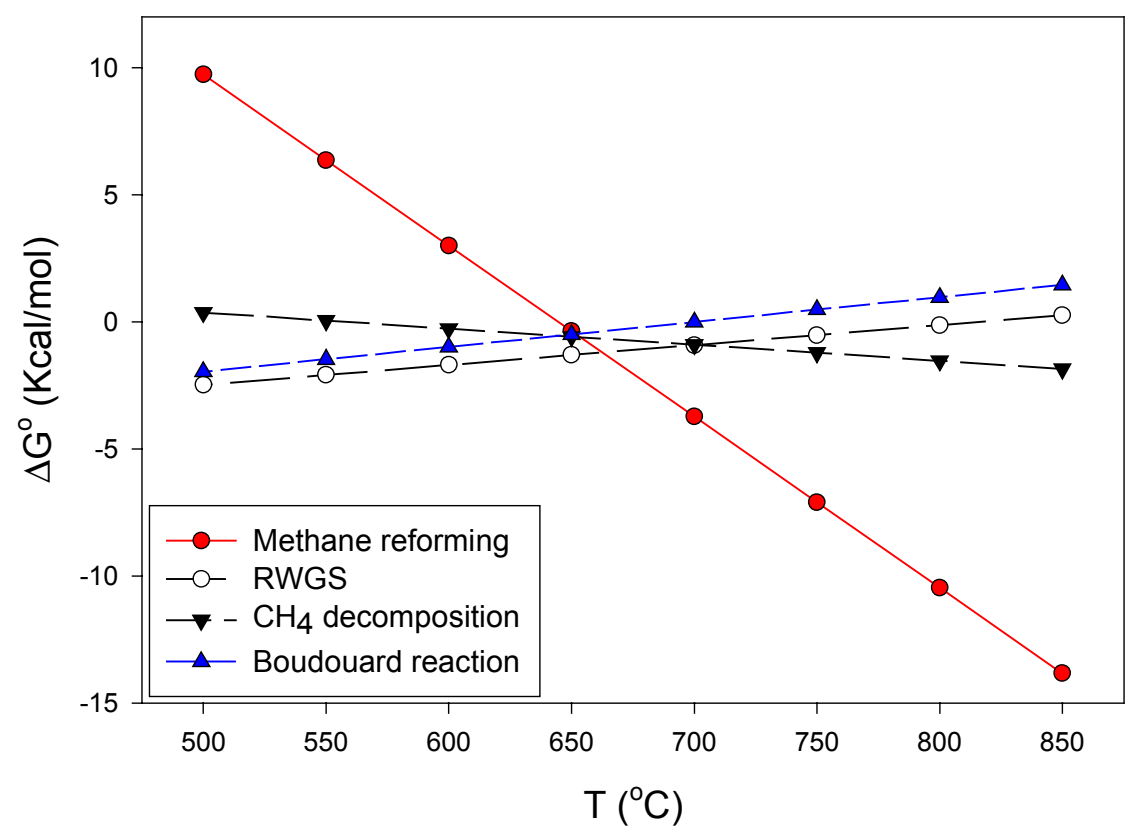

Figure 2.1. Temperature dependence of standard Gibbs free energy for various reactions in the $\mathrm{CH}_{4} / \mathrm{CO}_{2}$ reforming system. 
At a fixed temperature and with a feed ratio of $\mathrm{CH}_{4} / \mathrm{CO}_{2}=1$, conversions at lower total pressures are always greater than those at higher total pressures (Gadalla and Bower, 1988). For the same feed ratio, the tendency for carbon deposition increases for increasing total pressures. It can also be inferred that increasing $\mathrm{CO}_{2}$ in the feed may suppress carbon formation at lower temperatures (Wang et al. 1996). It has been observed that water is always formed in the reaction system due to the RWGS reaction, and its concentration is found to increase as the $\mathrm{CO}_{2}$ in the feed is increased. Formation of water leads to lower $\mathrm{H}_{2}$ than $\mathrm{CO}$. This is because some amount of the $\mathrm{H}_{2}$ formed in the dry reforming is consumed due to the RWGS reaction. However, $\mathrm{CO}$ is also formed in the RWGS reaction. Therefore, as the amount of $\mathrm{CO}$ in the system increases, the tendency for coke deposition by $\mathrm{CO}$ disproportionation (eqn. 1.5) becomes favorable. Further, as the total pressure is increased, the extent of RWGS reaction increases.

\subsection{Study of catalyst activity}

\subsubsection{Preparation}

Different methods for catalyst preparation influence the catalyst activity for the dry reforming reaction. The incipient-wetness impregnation technique (Bradford, 1997) is usually carried out for the preparation of the supported-metal catalysts. Also, an improved vacuum wetness technology was reported by Ashcroft et al. (1991), in which highly dispersed noble-metal catalysts could be obtained that could retain enough activity for dry reforming and suppress the carbon deposition at the same time. Addition of promoters to the catalysts has been found to improve the catalyst activity and selectivity 
at the same time. Gadalla and Sommer (1989) have reported varying compositions of $\mathrm{NiO}, \mathrm{MgO}$ and $\mathrm{Al}_{2} \mathrm{O}_{3}$ to increase the methane conversion. Fujimoto et al. (1992) have prepared $\mathrm{Ni} / \mathrm{CaO}-\mathrm{MgO}$ by co-precipitating hydroxides from aqueous solutions of $\mathrm{Ni}, \mathrm{Mg}$ and $\mathrm{Ca}$. Here the catalysts are prepared by a co-precipitation method.

\subsubsection{Activity}

Most of the group VIII metals ( $\mathrm{Rh}, \mathrm{Ru}, \mathrm{Ni}, \mathrm{Pt}, \mathrm{Pd}, \mathrm{Ir}, \mathrm{Co}, \mathrm{Fe}$ ) have been identified as preferred catalysts for dry reforming (Hei et al. 1998; Rostrup-Nielsen and Hansen, 1993; Wang et al., 1996). Apart from these metals, a few other catalysts are also reported to have shown activity for this reaction. Table 2.1 gives the results of the reforming reaction over these supported-metal catalysts. Hei et al. (1998) have shown that both the dissociation of $\mathrm{CH}_{4}$ and the dissociation of $\mathrm{CO}_{2}$ are rate-determining steps and they are promoted by each other. The activity sequence of the catalysts was found to be as: $\mathrm{Fe}>$ $\mathrm{Ni}>\mathrm{Rh}>\mathrm{Ru}>\mathrm{Ir}>\mathrm{Pd}>\mathrm{Pt}>\mathrm{Cu}$. However, $\mathrm{Fe}$ and $\mathrm{Ni}$ are more prone to carbon deposition as compared to the noble metals catalysts. Besides, Rh is more expensive than $\mathrm{Ru}$. Hence, $\mathrm{Ru}$ was reported to be the most suitable catalyst for $\mathrm{CO}_{2}$ reforming amongst the group VIII metals (Hei et al., 1998). From the non-noble metal catalysts, Ni was found to be more suitable than $\mathrm{Fe}$, as $\mathrm{Ni}$ is less likely to cause coking as compared to $\mathrm{Fe}$.

\subsubsection{Effect of catalyst support}

The nature of the oxide support for the catalyst has a significant effect on its activity due to the varying active surface area and the acid-base properties (Wang et al., 1996). The dry-reforming process involves adsorption and dissociation of $\mathrm{CO}_{2}$ on catalysts. $\mathrm{CO}_{2}$ 
being an acid gas, its adsorption and dissociation may be improved by a basic catalyst.

Table 2.2 gives an idea about the effect of supports on catalytic activity.

Table 2.1. Compilation of various catalyst systems investigated used for dry reforming (Bradford and Vannice, 1999; Wang et al., 1996)

\begin{tabular}{|c|c|c|c|c|}
\hline Catalyst system & $\mathrm{CO}_{2} / \mathrm{CH}_{4}$ & Conv. (\%) & $\mathbf{T}(\mathbf{K})$ & Reference \\
\hline $\mathrm{Ni} / \mathrm{NaY}$ & $1: 1$ & 84.0 & 873 & \multirow{5}{*}{ Kim et al. (1994) } \\
\hline $\mathrm{Ni} / \mathrm{Al}_{2} \mathrm{O}_{3}$ & $1: 1$ & 36.3 & 873 & \\
\hline $\mathrm{Ni} / \mathrm{SiO}_{2}$ & $1: 1$ & 14.9 & 873 & \\
\hline $\mathrm{Pd} / \mathrm{NaY}$ & $1: 1$ & 29.2 & 873 & \\
\hline $\mathrm{Pt} / \mathrm{NaY}$ & $1: 1$ & 156.3 & 873 & \\
\hline $\mathrm{KNiCa} / \mathrm{Al}_{2} \mathrm{O}_{3}$ & $1: 1$ & 17 & 923 & \multirow{3}{*}{ Park et al. (1995) } \\
\hline $\mathrm{KNiCa} / \mathrm{SiO}_{2}$ & $1: 1$ & 21 & 923 & \\
\hline $\mathrm{KNiCa} / \mathrm{ZSI}$ & $1: 1$ & 78 & 923 & \\
\hline $\mathrm{Rh} / \mathrm{TiO}_{2}$ & $1: 1$ & 88.2 & 893 & \multirow{3}{*}{ Nakamura et al. (1994) } \\
\hline $\mathrm{Rh} / \mathrm{SiO}_{2}$ & $1: 1$ & 5.1 & 893 & \\
\hline $\mathrm{Rh} / \mathrm{Al}_{2} \mathrm{O}_{3}$ & $1: 1$ & 85.1 & 893 & \\
\hline $\mathrm{Ni} / \mathrm{Al}_{2} \mathrm{O}_{3}$ & $1: 1$ & $80-90$ & 1050 & \multirow{5}{*}{ Ashcroft et al. (1991) } \\
\hline $\mathrm{Pd} / \mathrm{Al}_{2} \mathrm{O}_{3}$ & $1: 1$ & $70-75$ & 1050 & \\
\hline $\mathrm{Ru} / \mathrm{Al}_{2} \mathrm{O}_{3}$ & $1: 1$ & $60-70$ & 1050 & \\
\hline $\mathrm{Rh} / \mathrm{Al}_{2} \mathrm{O}_{3}$ & $1: 1$ & $85-90$ & 1050 & \\
\hline $\mathrm{Ir} / \mathrm{Al}_{2} \mathrm{O}_{3}$ & $1: 1$ & $85-90$ & 1050 & \\
\hline $\mathrm{Co}, \mathrm{MgO} / \mathrm{C}$ & $1: 1$ & $65-75$ & 923 & Guerrero-Ruiz et al. (1993) \\
\hline $\mathrm{Ni} / \mathrm{CaO}-\mathrm{MgO}$ & $1: 1$ & 80 & 1123 & Fujimoto et al. (1992) \\
\hline $\mathrm{Rh} / \mathrm{Al}_{2} \mathrm{O}_{3}$ & $1: 1$ & 85 & 1073 & \multirow{2}{*}{ Richardson and Paripatyadar } \\
\hline $\mathrm{Ru} / \mathrm{Al}_{2} \mathrm{O}_{3}$ & $1: 1$ & 83 & 1073 & \\
\hline $\mathrm{Ru} / \mathrm{Eu}_{2} \mathrm{O}_{3}$ & $1: 1$ & 75 & 923 & \multirow[t]{2}{*}{ Perera et al. (1991) } \\
\hline $\mathrm{Ir} / \mathrm{Eu}_{2} \mathrm{O}_{3}$ & $1: 1$ & 88 & 1000 & \\
\hline $\mathrm{Ru} / \mathrm{MgO}$ & $1: 1$ & 90 & 963 & \multirow{4}{*}{ Takayasu et al. (1991) } \\
\hline $\mathrm{Rh} / \mathrm{MgO}$ & $1: 1$ & 88 & 963 & \\
\hline $\mathrm{Pt} / \mathrm{MgO}$ & $1: 1$ & 85 & 963 & \\
\hline $\mathrm{Pd} / \mathrm{MgO}$ & $1: 1$ & 84 & 963 & \\
\hline $\mathrm{Ni} / \mathrm{Al}_{2} \mathrm{O}_{3}$ & $2.38: 1$ & 100 & 1213 & \multirow{3}{*}{ Gadalla and Bower (1988) } \\
\hline $\mathrm{Ni} / \mathrm{MgO}-\mathrm{Al}_{2} \mathrm{O}_{3}$ & $2.38: 1$ & 86 & 1211 & \\
\hline $\mathrm{Ni} / \mathrm{CaO}-\mathrm{Al}_{2} \mathrm{O}_{3}$ & 2.01:1 & 88 & 1211 & \\
\hline $\mathrm{Ni} / \mathrm{CaO}-\mathrm{TiO}_{2}-\mathrm{Al}_{2} \mathrm{O}_{3}$ & $2.01: 1$ & 100 & 1223 & Gadalla and Sommer (1989) \\
\hline
\end{tabular}


Table 2.2. Effect of support on the catalyst activity (Wang et al., 1996)

\begin{tabular}{|c|c|c|c|}
\hline Order of catalytic activity & $\mathbf{T}(\mathbf{K})$ & $\begin{array}{l}\text { Metal Loading } \\
\text { (wt. \%) }\end{array}$ & Reference \\
\hline \multicolumn{4}{|l|}{$\mathrm{Ru}$} \\
\hline $\mathrm{Al}_{2} \mathrm{O}_{3}>\mathrm{TiO}_{2}>\mathrm{SiO}_{2}$ & 893 & 0.5 & Nakamura et al. (1994) \\
\hline $\mathrm{TiO}_{2}>\mathrm{Al}_{2} \mathrm{O}_{3}>\mathrm{SiO}_{2}$ & 893 & 0.5 & Nakamura et al. (1994) \\
\hline \multicolumn{4}{|l|}{$\mathrm{Pd}$} \\
\hline $\begin{array}{l}\mathrm{TiO}_{2}>\mathrm{Al}_{2} \mathrm{O}_{3}>\mathrm{NaY}>\mathrm{SiO}_{2}>\mathrm{MgO} \\
>\text { Na-ZSM-5 }\end{array}$ & 773 & 5 & Masai et al. (1988) \\
\hline $\mathrm{TiO}_{2}>\mathrm{Al}_{2} \mathrm{O}_{3}>\mathrm{SiO}_{2}>\mathrm{MgO}$ & 773 & 1 & Erdoehelyi et al. (1994) \\
\hline \multicolumn{4}{|l|}{$\mathrm{Rh}$} \\
\hline $\begin{array}{l}\mathrm{YSZ}>\mathrm{Al}_{2} \mathrm{O}_{3}>\mathrm{TiO}_{2}>\mathrm{SiO}_{2} \\
>>\mathrm{MgO}\end{array}$ & 923 & 0.5 & Tsipouriari et al. (1994) \\
\hline $\mathrm{Al}_{2} \mathrm{O}_{3}>\mathrm{SiO}_{2}>\mathrm{TiO}_{2}>\mathrm{MgO}$ & 773 & 1 & Erdoehelyi et al. (1993) \\
\hline \multicolumn{4}{|l|}{$\mathrm{Ni}$} \\
\hline $\mathrm{Al}_{2} \mathrm{O}_{3}>\mathrm{SiO}_{2}$ & $\begin{array}{l}800- \\
1000 \\
\end{array}$ & 40 & Takano et al. (1994) \\
\hline $\mathrm{Al}_{2} \mathrm{O}_{3}>\mathrm{SiO}_{2}$ & 873 & 10 & $\begin{array}{l}\text { Tokunaga and } \\
\text { Ogasawara }(1989)\end{array}$ \\
\hline $\mathrm{NaY}>\mathrm{Al}_{2} \mathrm{O}_{3}>\mathrm{SiO}_{2}$ & 873 & 2 & Kim et al. (1994) \\
\hline $\begin{array}{l}\mathrm{SiO}_{2}>\mathrm{ZrO}_{2}>\mathrm{La}_{2} \mathrm{O}_{3}>\mathrm{MgO}> \\
\mathrm{TiO}_{2}\end{array}$ & 823 & 4 & Swaan et al. (1994) \\
\hline
\end{tabular}

\subsection{Carbide Catalysts}

The interest in the potential applications of molybdenum and tungsten carbides to catalyze various reactions started from the early 1970s. Levy and Boudart (1973), reported the application of $\alpha$-WC for neo-pentane isomerization and discovered the catalytic similarities between tungsten carbide and platinum. This triggered further investigations for synthesizing high-surface-area metal carbides by high-temperature reaction of metals with carbon. Molybdenum and tungsten carbides have been found to catalyze all types of methane-reforming reactions, and to some extent have activities comparable to that of the noble metals (York, 1999). These metal carbides have been found to drive the reaction to thermodynamic equilibrium such that very high conversions 
and syngas selectivity as high as $90 \%$ could be obtained. These carbides are very stable at elevated pressures and are resistant to carbon deposition, which can challenge the commercial use of nickel catalysts, which are prone to deactivation from coke formation.

Several studies have been pursued to determine the similarities between the catalytic behavior of platinum and these carbide catalysts. Most of the transition metals strongly adsorb molecules on their surface. But treatment with carbon decreases the binding energy and allows catalytic turnover. The carbon in the carbide donates electrons to the $\mathrm{d}$ band of the metal. This addition of electrons enhances the electronic properties of tungsten and/or molybdenum and makes them coincide with that of platinum (York, 1999). However, it has also been found that treating the surface of molybdenum carbide with oxygen creates a new catalytic phase, molybdenum oxycarbide, which contains oxygen atoms on its surface and in the bulk (Oyama et al., 1997). Although this phase is less active than platinum, it is more resistant to catalyst poisons such as sulfur (York, 1999).

\subsubsection{Tungsten Carbides}

Vreugdenhil et al. (1994) have patented information wherein tungsten carbides could be prepared by the calcination of a mixture of a non-oxygen-containing acyclic compound containing carbon-nitrogen-hydrogen bonding and a tungsten salt. The tungsten salt and the acyclic compound were mixed together in near-stoichiometric amounts by adding solutions of each component or by admixing the dry solid compounds. The calcination was then carried out at a temperature range of $400-900{ }^{0} \mathrm{C}$ for about 1-5 hours in an inert atmosphere of helium, argon or nitrogen. The tungsten carbide formed is considered to be an interstitial alloy and is an excellent electrical 
conductor with good hydrolytic stability. It was also found to be of high purity and porosity, with a surface area of about $200-300 \mathrm{~m}^{2} / \mathrm{g}$.

Kugler et al. (1992) have patented methods for producing eta-phase materials. This includes providing a precursor compound which has at least two eta-phase-forming metals (viz. $\mathrm{W}$ and $\mathrm{Co}$ ) and a ligand containing carbon or nitrogen or combination of both. The reactive precursor was prepared by reductive decomposition of $\mathrm{Co}(\mathrm{en})_{3} \mathrm{WO}_{4}$, followed by heating in a flowing mixture of $\mathrm{He}$ and $\mathrm{H}_{2}$ up to a temperature of $650{ }^{\circ} \mathrm{C}$, and finally cooling to room temperature. The reactive precursor was then passivated in $\mathrm{He} / \mathrm{O}_{2}$ and then heated in flowing $\mathrm{Ar}$ to $700-1000{ }^{\circ} \mathrm{C}$. The Ar was then replaced by a $\mathrm{CO}_{2} / \mathrm{CO}$ mixture. The sample was then held in the reactive $\mathrm{CO}_{2} / \mathrm{CO}$ mixture for a sufficient time such that the carbon activity in the precursor reaches equilibrium with that in the flowing $\mathrm{CO}_{2} / \mathrm{CO}$ mixture. Samples were then obtained without passivation to get the desired pure $\mathrm{Co}_{6} \mathrm{~W}_{6} \mathrm{C}$ eta-carbide phase. The cobalt tungsten carbide catalyst $\left[\mathrm{Co}_{6} \mathrm{~W}_{6} \mathrm{C}\right]$ obtained for our study was probably prepared by a similar method.

\subsubsection{Molybdenum Carbides}

Lee et al. (1987) and Oyama (1981) have reported a synthesis technique for the preparation of molybdenum carbide powders. In this process, $\mathrm{MoO}_{3}$ with a low specific surface area is heated at slowly increasing temperatures in a stream of $\mathrm{CH}_{4} / \mathrm{H}_{2}$ mixture so that temperature-programmed reduction (TPR) of molybdenum oxide takes place. This produces unsupported powders of hexagonal $\mathrm{Mo}_{2} \mathrm{C}$ with a specific surface area of 50-100 $\mathrm{m}^{2} / \mathrm{g}$ and a CO uptake density of up to $5 \times 10^{14} \mathrm{~cm}^{-2}$. The material could be synthesized either with a surface free of contamination by noncarbidic carbon $\left(\mathrm{Mo}_{2} \mathrm{C}-\mathrm{I}\right)$ or with a 
surface completely covered by polymeric carbon layers $\left(\mathrm{C}-\mathrm{Mo}_{2} \mathrm{C}\right)$, depending on the method of preparation.

Claridge et al. (1998) have reported identical procedures for the preparation of carbide catalysts, but have stressed the passivation of the prepared catalyst in $1 \% \mathrm{O}_{2}$ stream at room temperature before exposure to the atmosphere, as the carbides are readily oxidized by air at room temperature. Shamsi and Lyons (2000) have reported following a similar route, but the TPR of molybdenum oxide was carried out with a stream of 11.6 vol. \% ethane or methane in hydrogen.

\subsubsection{Catalyst Testing}

Shamsi and Lyons (2000) compared the catalytic activity of the carbide catalysts with commercial nickel-based and noble-metal catalysts. The results of the tests are shown in Table 2.3, the feed ratio being $\mathrm{CH}_{4} / \mathrm{CO}_{2}=1.1$ at a $\mathrm{GHSV}=5040 \mathrm{~cm}^{3} / \mathrm{g} / \mathrm{h}$ at 1 atm pressure. Shamsi and Lyons reported that pure, unsupported tungsten carbide gave better conversions than that supported on silica, although data with the silica-supported tungsten carbide catalyst are not available. However, the unsupported tungsten-carbide catalyst is found to deactivate after 35 hours on stream and cannot be regenerated. The commercial Ni-based catalysts were found to have substantial activity. However, after 5 hours on stream, the reactor gets plugged because of carbon formation on the Ni surfaces. The unsupported tungsten carbide catalyst was observed before and after the experiments using X-ray diffraction. The patterns showed that tungsten carbide oxidized to tungsten oxide during the reactions. 
Table 2.3. Methane dry reforming over carbide, Ni-based and noble-metal catalysts (Shamsi and Lyons, 2000).

\begin{tabular}{|c|c|c|c|c|c|c|c|c|}
\hline Catalyst & \multicolumn{2}{|c|}{$\% \mathrm{CH}_{4}$ conv. } & \multicolumn{2}{|c|}{$\% \mathrm{CO}_{2}$ conv. } & \multicolumn{2}{|c|}{ \% CO yield } & \multicolumn{2}{|c|}{$\mathrm{H}_{2} / \mathrm{CO}$ ratio } \\
\hline Temp. $\left({ }^{0} \mathrm{C}\right)$ & 750 & 850 & 750 & 850 & 750 & 850 & 750 & 850 \\
\hline $\mathrm{Mo}_{2} \mathrm{C}^{1}$ & 18.3 & 92.1 & 37.3 & 99.8 & 37.3 & 96 & 0.3 & 1.0 \\
\hline $\mathrm{Mo}_{2} \mathrm{C}^{2}$ & 36.9 & 89.5 & 59.1 & 99.9 & 51.6 & 89.4 & 0.7 & 1.1 \\
\hline $\mathrm{Mo}_{2} \mathrm{C} / \mathrm{TiO}_{2}$ & 69.9 & 70.1 & 87.1 & 88.7 & 76.2 & 77.8 & 0.9 & 0.9 \\
\hline $\begin{array}{l}\text { Tungsten } \\
\text { Carbide } \\
\text { (unsupported) }\end{array}$ & 5.4 & 90.7 & 12.0 & 99.7 & 13.4 & 86.6 & 0.2 & 1.1 \\
\hline R-67, Topsoe 3 & 94.2 & 98.9 & 91.1 & 95.2 & 95.3 & 99.1 & 1.0 & 1.0 \\
\hline $\mathrm{G}-56 \mathrm{~B}, \mathrm{UCI}^{3}$ & 96.1 & 99.1 & 90.3 & 97.1 & 93.2 & 99.8 & 1.0 & 1.0 \\
\hline $\mathrm{Rh} / \mathrm{Al}_{2} \mathrm{O}_{3}$ & 86.9 & 97.2 & 88.1 & 97.4 & 88 & 95.7 & 1.0 & 1.1 \\
\hline
\end{tabular}

\footnotetext{
${ }^{1} \mathrm{TPR}$ of $\mathrm{MoO}_{3}$ using $11.6 \%$ methane in $\mathrm{H}_{2}$

2 TPR of $\mathrm{MoO}_{3}$ using $11.6 \%$ ethane in $\mathrm{H}_{2}$

${ }^{3}$ Commercial Ni-based catalyst
}

Claridge et al. (1998) have obtained results for dry reforming using $\beta-\mathrm{Mo}_{2} \mathrm{C}$ and $\alpha$-WC catalysts for ambient and elevated pressures with a equimolar feed ratio and GHSV $=2.87 \times 10^{3} \mathrm{~h}^{-1}$. The results are tabulated in Table 2.4. At ambient pressures (1 bar), the carbides were found to deactivate due to oxidation of the catalyst to $\mathrm{MO}_{2}$, while operating at a higher pressure $(8.3$ bar) resulted in stabilization of the catalyst and no deactivation. High-resolution transmission electron microscopy (HRTEM) studies showed that no macroscopic carbon was found to deposit on the catalysts after the reaction at elevated pressures. The relative activities of the carbide catalysts and the other established catalysts is: $\mathrm{Ru}>\mathrm{Rh} \cong \mathrm{Mo}_{2} \mathrm{C}>\mathrm{Ir}>\mathrm{WC}>\mathrm{Pd}>\mathrm{Pt}$. 
Table 2.4. Methane dry reforming over metal carbide catalysts (Claridge $e t$ al., 1998).

\begin{tabular}{|l|c|c|c|c|c|c|}
\hline Catalyst & $\begin{array}{c}\text { Temp. } \\
\text { (K) }\end{array}$ & $\begin{array}{c}\text { Pressure } \\
\text { (bar) }\end{array}$ & $\begin{array}{c}\text { \% CH. } \\
\text { conv. }\end{array}$ & $\begin{array}{c}\text { \% CO } \\
\text { conv }\end{array}$ & $\begin{array}{c}\text { \% CO } \\
\text { yield }\end{array}$ & $\begin{array}{c}\mathbf{H}_{2} / \mathbf{C O} \\
\text { ratio }\end{array}$ \\
\hline \multirow{3}{*}{$\beta-\mathrm{Mo}_{2} \mathrm{C}$} & 1120 & 1.0 & 92.4 & 92.5 & 92.5 & 0.93 \\
\cline { 2 - 7 } & 1220 & 1.0 & 98.8 & 95.9 & 95.9 & 0.92 \\
\cline { 2 - 7 } & 1120 & 8.3 & 62.5 & 75.9 & 69.5 & 0.78 \\
\cline { 2 - 7 } & 1170 & 8.3 & 73.5 & 83.7 & 78.8 & 0.83 \\
\cline { 2 - 7 } & 1220 & 8.3 & 83.3 & 89.5 & 86.5 & 0.88 \\
\hline \multirow{3}{*}{$\alpha-\mathrm{WC}$} & 1120 & 1.0 & 92.0 & 93.1 & 92.6 & 0.94 \\
\cline { 2 - 7 } & 1120 & 8.3 & 62.7 & 75.4 & 68.6 & 0.79 \\
\hline$\beta-\mathrm{Mo}_{2} \mathrm{C}_{\mathrm{Al}_{2} \mathrm{O}_{3}}$ & 1120 & 1.0 & 92.6 & 92.4 & 92.5 & 0.95 \\
\hline & 1120 & 8.3 & 65.1 & 80.7 & 73.1 & 0.81 \\
\hline
\end{tabular}

Claridge et al. (1998) also carried out combined steam- and-dry-reforming (eqn.

1.1 and 1.2 respectively) using the metal carbide catalysts. The metal carbides could be used in the presence of both $\mathrm{CO}_{2}$ and $\mathrm{H}_{2} \mathrm{O}$. The independent reactions for steam- and dry-reforming are given earlier. The catalysts were stable at the elevated pressure (8.7 bar) for more than 72 hours. No macroscopic carbon deposition was observed. The results of the combined reforming are tabulated in Table 2.5.

Table 2.5. Combined steam and dry reforming over metal carbide catalysts $\left(\mathrm{T}=1170 \mathrm{~K}, \mathrm{P}=8.7 \mathrm{bar}, \mathrm{GHSV}=5.2 \times 10^{3} \mathrm{~h}^{-1}, \mathrm{CH}_{4}: \mathrm{CO}_{2}: \mathrm{H}_{2} \mathrm{O}=3: 1: 2\right)($ Claridge $e t$ al, 1998).

\begin{tabular}{|c|c|c|c|c|c|c|}
\hline Catalyst & $\begin{array}{c}\% \mathrm{CH}_{\mathbf{4}} \\
\text { conv. }\end{array}$ & $\begin{array}{c}\% \mathrm{H}_{2} \\
\text { selectivity }\end{array}$ & $\begin{array}{c}\% \mathbf{C O} \\
\text { selectivity }\end{array}$ & $\begin{array}{c}\text { \% } \mathrm{CO}_{2} \\
\text { selectivity }\end{array}$ & $\begin{array}{c}\mathbf{\%} \mathrm{H}_{2} \mathbf{O} \\
\text { selectivity }\end{array}$ & $\begin{array}{c}\mathrm{H}_{2} / \mathbf{C O} \\
\text { ratio }\end{array}$ \\
\hline$\beta-\mathrm{Mo}_{2} \mathrm{C}$ & 91.3 & 94.9 & 91.3 & 8.6 & 5.1 & 2.00 \\
\hline$\alpha-\mathrm{WC}$ & 92.0 & 93.4 & 92.4 & 7.6 & 6.6 & 1.97 \\
\hline$\beta-\mathrm{Mo}_{2} \mathrm{C} / \mathrm{Al}_{2} \mathrm{O}_{3}$ & 90.7 & 96.1 & 91.7 & 8.3 & 3.9 & 2.02 \\
\hline
\end{tabular}


From Table 2.5, the product selectivity towards $\mathrm{H}_{2}$ and $\mathrm{CO}$ is higher than the other side products. The $\mathrm{H}_{2} / \mathrm{CO}$ ratio is close to 2 , consistent with a simple addition of eqn (1.1) and (1.2):

$3 \mathrm{CH}_{4}+\mathrm{CO}_{2}+2 \mathrm{H}_{2} \mathrm{O} \rightleftarrows 4 \mathrm{CO}+8 \mathrm{H}_{2}$

The $\mathrm{CH}_{4}$ conversion for the combined reforming (Table 2.5) is higher than that for dry reforming (Table 2.4), under similar operating conditions of temperatures and pressures.

\subsection{Reaction mechanism and kinetics}

\subsubsection{Background}

Until recent times, there have been only a few reports on the kinetic studies of methane dry reforming cited in the literature. Most of the research efforts have been focused on the preparation of catalysts, evaluating the catalyst performance and understanding the thermodynamics of the reaction system. The kinetics and the mechanism depend on the type of catalyst, the nature of support and the operating temperature range (Lu and Wang, 1999). Hence, there has been no universal expression derived for this reaction system. We shall now see some of the reaction kinetic models and mechanisms proposed by involving a variety of catalysts.

\subsubsection{Power-law kinetic models}

There have been various reports where the dry-reforming kinetics and the rate expressions have been approximated by a simple power-law equation given as: 


$$
\mathrm{r}=\mathrm{k}\left[\mathrm{P}_{\mathrm{CH} 4}\right]^{\mathrm{m}}\left[\mathrm{P}_{\mathrm{CO} 2}\right]^{\mathbf{n}}
$$

The values of these power-law rate coefficients for various catalyst systems have been tabulated by Wang et al. (1996) and are given in Table 2.6 below. However, Wang et al. have not reported the details of the reaction conditions at which these values were obtained.

Table 2.6. Parameters of the power law equation (Wang et al. 1996)

\begin{tabular}{|c|c|c|c|}
\hline Catalyst & $\mathbf{m}$ & $\mathbf{n}$ & Reference \\
\hline $\mathrm{Ni} / \mathrm{SiO}_{2}$ & 0.8 & 0 & Takano et al. (1994) \\
\hline $\mathrm{Ni} / \mathrm{Al}_{2} \mathrm{O}_{3}$ & 1.0 & 0 & Takano et al. (1994) \\
\hline $\mathrm{Ni} / \mathrm{SiO}_{2}$ & $0.02-0.05$ & $0.5-0.6$ & Sakai et al. (1984) \\
\hline $\mathrm{Rh} / \mathrm{Al}_{2} \mathrm{O}_{3}$ & $0.02-0.09$ & $0.4-0.5$ & Sakai et al. (1984) \\
\hline $\mathrm{Ni} / \mathrm{Al}_{2} \mathrm{O}_{3}$ & 0.6 & 0.3 & Tokunaga and Ogasawara (1989) \\
\hline $\mathrm{Pd} / \mathrm{SiO}_{2}$ & 0.47 & 0.36 & Erdoehelyi et al. (1994) \\
\hline $\mathrm{Ni} / \mathrm{SiO}_{2}$ & -0.30 & 0.16 & Osaki et al. (1995) \\
\hline $\mathrm{Ni} / \mathrm{MgO}$ & 1.0 & 0 & \multirow{6}{*}{$\begin{array}{l}\text { Rostrup-Nielsen and Bak-Hansen } \\
\qquad \text { (1993) }\end{array}$} \\
\hline $\mathrm{Ru} / \mathrm{MgO}$ & 1.0 & 0 & \\
\hline $\mathrm{Rh} / \mathrm{MgO}$ & 1.0 & 0 & \\
\hline $\mathrm{Pd} / \mathrm{MgO}$ & 1.0 & 0 & \\
\hline $\mathrm{Ir} / \mathrm{MgO}$ & 1.0 & 0 & \\
\hline $\mathrm{Pt} / \mathrm{MgO}$ & 1.0 & 0 & \\
\hline $\mathrm{Rh} / \mathrm{Al}_{2} \mathrm{O}_{3}$ & $0-1$ & $0-1$ & Richardson and Paripatyadar (1990) \\
\hline
\end{tabular}

The advantage of these models is the simplicity in application and determination. However, over a wider range of partial pressure data and from various mechanistic schemes proposed, these models are inadequate to explain the various reaction steps taking place on the catalyst surface. Hence, it becomes necessary to understand the mechanistic aspects of the reforming reaction. Based on these mechanisms, some 
researchers have proposed Langmuir-Hinshelwood, Eley-Rideal and Hougen-Watson type of reaction models.

\subsubsection{Reaction mechanisms}

There have been various step-wise mechanisms proposed for the dry reforming reaction between $\mathrm{CO}_{2}$ and $\mathrm{CH}_{4}$. The earliest mechanism was proposed by Bodrov and Apel'baum (1967) based on the steam reforming of methane over a Ni foil.

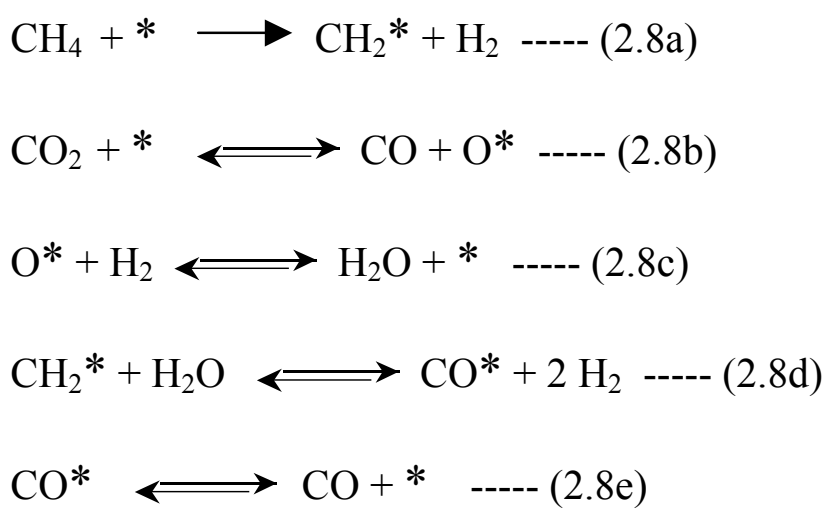

Later on, Nakamura et al. (1994) proposed a conceptual mechanism similar to the former sequence of steps. Firstly, $\mathrm{CH}_{4}$ gets dissociatively adsorbed on an active site to yield the $\mathrm{CH}_{2}$ species. This is the rate-determining step. $\mathrm{CO}_{2}$ gets converted to $\mathrm{H}_{2} \mathrm{O}$ by the RWGS reaction. Subsequently, $\mathrm{H}_{2} \mathrm{O}$ reacts with the $\mathrm{CH}_{2}$ species to produce $\mathrm{H}_{2}$ and CO.

Erdohelyi et al. (1993) and Rostrup-Neilsen and Bak-Hansen (1993) proposed some modifications to the mechanism shown above. These allow a distribution of $\mathrm{CH}_{\mathrm{x}}$ species to exist on the catalyst surface. Further, the $\mathrm{H}$ atoms promote $\mathrm{CO}_{2}$ dissociation. Consequently, the adsorbed $\mathrm{O}$ atom, rather than the gas-phase $\mathrm{H}_{2} \mathrm{O}$, reacts with the adsorbed $\mathrm{CH}_{\mathrm{x}}$ species. These steps are as shown below: 


$$
\begin{aligned}
& \mathrm{CH}_{4}+2 * \longrightarrow \mathrm{CH}_{3}^{*}+\mathrm{H}^{*} \text {---- }(2.9 \mathrm{a}) \\
& \mathrm{CH}_{3}{ }^{*}+(3-\mathrm{x})^{*} \longleftrightarrow \mathrm{CH}_{\mathrm{x}}^{*}+(3-\mathrm{x}) \mathrm{H}^{*} \text {---- }(2.9 \mathrm{~b}) \\
& \mathrm{CO}_{2}+\mathrm{H}^{*} \longleftrightarrow \mathrm{CO}+\mathrm{HO}^{*}----(2.9 \mathrm{c}) \\
& 2 \mathrm{HO}^{*} \rightleftarrows \mathrm{H}_{2} \mathrm{O}+\mathrm{O}^{*}+{ }^{*}----(2.9 \mathrm{~d}) \\
& \mathrm{CH}_{\mathrm{x}}^{*}+\mathrm{O}^{*}+(\mathrm{x}-2)^{*} \longleftrightarrow \mathrm{CO}+\mathrm{x} \mathrm{H}^{*}----(2.9 \mathrm{e}) \\
& 2 \mathrm{H}^{*} \rightleftarrows \mathrm{H}_{2}+2^{*}----(2.9 \mathrm{f})
\end{aligned}
$$

Wang et al. (1996) and $\mathrm{Lu}$ and Wang (1999) have proposed a step-wise mechanistic model based on their kinetic work with $\mathrm{Ni} / \mathrm{Al}_{2} \mathrm{O}_{3}$ and $\mathrm{Ni} / \mathrm{CeO}_{2}-\mathrm{Al}_{2} \mathrm{O}_{3}$. It can be given as follows:

1. dehydrogenation of methane to form surface carbon and hydrogen.

2. dissociative adsorption of $\mathrm{CO}_{2}$ and $\mathrm{H}_{2}$

3. reduction of $\mathrm{CO}_{2}$ to $\mathrm{CO}$

It can be represented schematically as follows:

$$
\begin{aligned}
& \mathrm{CH}_{4}+* \longrightarrow \mathrm{C}^{*}+4 \mathrm{H}^{*} \text {---- }(2.10 \mathrm{a}) \\
& \mathrm{CO}_{2}+2^{*} \longrightarrow \mathrm{CO}^{*}+\mathrm{O}^{*} \text {---- }(2.10 \mathrm{~b}) \\
& \mathrm{C}^{*}+\mathrm{O}^{*} \longrightarrow \mathrm{CO}^{*}+{ }^{*} \text {---- }(2.10 \mathrm{c}) \\
& \mathrm{CO}^{*} \longrightarrow \mathrm{CO}^{*}+\mathrm{H}_{2}+2^{*} \text {---- }(2.10 \mathrm{e}) \\
& 2 \mathrm{H}^{*} \longrightarrow \mathrm{CO}^{*}-\mathrm{C}^{*}(2.10 \mathrm{f}) \\
& \mathrm{CO}_{2}+\mathrm{C}^{*} \longrightarrow \mathrm{H}_{2} \mathrm{O}+3 * \text {---- }(2.10 \mathrm{~g}) \\
& 2 \mathrm{H}^{*}+\mathrm{O}^{*} \longrightarrow
\end{aligned}
$$


The methane decomposition step (2. 10a) takes place in stages where a $\mathrm{CH}_{x}$ species is formed and it then consequently decomposes to form surface carbon and hydrogen. The rate-determining step is given as:

$$
\mathrm{CH}_{\mathrm{x}} *+\mathrm{CO}_{2} * \longrightarrow 2 \mathrm{CO}+\mathrm{x} / 2 \mathrm{H}_{2}+2 * \text {---- }(2.10 \mathrm{~h})
$$

Ferreira-Aparicio et al. (1999) have reported of transient kinetic studies over Ru catalysts supported on silica, alumina and high-surface-area graphite. They have suggested a series of steps that can be explained as follows:

(a) Methane activation:

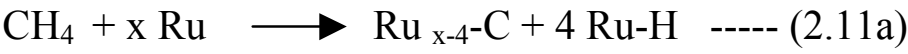

$$
\begin{aligned}
& 2 \mathrm{Ru}-\mathrm{H} \longleftrightarrow \mathrm{H}_{2}+2 \mathrm{Ru} \quad----(2.11 \mathrm{~b})
\end{aligned}
$$

(b) Carbon dioxide activation:

$$
\begin{aligned}
& \mathrm{CO}_{2}+\mathrm{Ru} \longleftrightarrow \mathrm{Ru}^{-\mathrm{CO}_{2}}-----(2.11 \mathrm{c}) \\
& \mathrm{Ru}-\mathrm{CO}_{2}+\mathrm{Ru} \longleftrightarrow \mathrm{Ru}-\mathrm{CO}+\mathrm{Ru}-\mathrm{O}----(2.11 \mathrm{~d}) \\
& \mathrm{Ru}-\mathrm{CO}+\mathrm{Ru} \longleftrightarrow \mathrm{Ru}-\mathrm{C}+\mathrm{Ru}-\mathrm{O}----(2.11 \mathrm{e}) \\
& \mathrm{Ru}-\mathrm{CO} \longleftrightarrow \mathrm{CO}+\mathrm{Ru}----(2.11 \mathrm{f})
\end{aligned}
$$

(c) $\mathrm{H}_{2} \mathrm{O}$ formation:

$$
\begin{aligned}
& \mathrm{Ru}-\mathrm{O}+\mathrm{Ru}-\mathrm{H} \longleftrightarrow \mathrm{Ru}-\mathrm{OH}+\mathrm{Ru}----(2.11 \mathrm{~g}) \\
& 2 \mathrm{Ru}-\mathrm{OH} \longleftrightarrow \mathrm{Ru}-\mathrm{O}+\mathrm{Ru}+\mathrm{H}_{2} \mathrm{O}-----(2.11 \mathrm{~h})
\end{aligned}
$$

The step (2.11a) represents a global methane cracking reaction that includes fast and step-wise intermediate dehydrogenation steps. However, it was observed that no $C_{n}$ species are formed as the activated carbon species, instead of being hydrogenated, are oxidized to form carbon monoxide. This confirms the process of carbon dioxide activation, which serves as a source of oxygen for carbon oxidation. However, this also 
leads to the simultaneous occurrence of RWGS reaction. Results indicate that, under the reforming conditions, there is no accumulation of $\mathrm{CO}_{2}$ that rapidly desorbs. Hence, (2.11d) is faster than step (2.11c) and both of them can be combined to give a single step for the dissociative adsorption of $\mathrm{CO}_{2}$.

Kroll et al. (1997) have investigated the mechanistic aspects of dry reforming over a $\mathrm{Ni} / \mathrm{SiO}_{2}$ catalyst using isotopic transient experiments combined with in situ DRIFT spectroscopy techniques. They propose the following mechanistic steps:

(a) Methane activation: This consists of a reversible reaction between gaseous methane molecules and active sites forming adsorbed carbon and gaseous $\mathrm{H}_{2}$. This lead to the formation of a pool of a monolayer of carbide-like active intermediate species. This step does include the formation of $\mathrm{CH}_{\mathrm{x}}$ species and gas-surface hydrogen equilibrium. However, there is no accumulation of adsorbed $\mathrm{H}^{*}$ or $\mathrm{CH}_{\mathrm{x}}$ species. Hence, this step can be considered as a fast, reversible step leading to the formation of dehydrogenated carbon monomers given as:

$\mathrm{CH}_{4}+* \longleftrightarrow \mathrm{C}^{*}+4 \mathrm{H}^{*}----(2.12 \mathrm{a})$

(b) Carbon dioxide activation: Carbon dioxide was found to be in equilibrium with the surface and convertible to carbon monoxide. This could be further explained as:

1. Dissociative adsorption of $\mathrm{CO}_{2}$ on a active site leading to the formation of surface oxygen and $\mathrm{CO}$, which is immediately released in the gas phase.

$\mathrm{CO}_{2}+* \longleftrightarrow \mathrm{CO}+\mathrm{O}^{*}$ 
2. The surface carbon monomers arising from step (2.12a) then react with these surface oxygen atoms from step (2.12b) to give $\mathrm{CO}$, which gets released in the gas phase instantaneously.

$\mathrm{C}^{*}+\mathrm{O}^{*} \longrightarrow \mathrm{CO}+2 *----(2.12 \mathrm{c})$

Step (2.12b) is highly reversible and fast as compared to the step (2.12c), which governs the accumulation of the various surface intermediates. It was also observed that the overall rate-determining step (rds) of the process does not involve any $\mathrm{C}-\mathrm{H}$ bond formation or breakage. Consequently, Kroll et al. proposed step (2.12c) as the rate-determining step as it requires surface migration of species like surface carbon and oxygen.

(c) Kroll et al. (1997) also include the kinetic role of water into the mechanism.

$$
\mathrm{H}_{2} \mathrm{O}+* \longleftrightarrow \mathrm{H}_{2}+\mathrm{O}^{*}
$$

They suggested that water interacts reversibly with the catalyst surface, similar to $\mathrm{CO}_{2}$, and thus they could account for the water-gas-shift equilibrium.

Efstathiou et al. (1996) investigated the mechanistic aspects of dry reforming of methane using steady-state tracing techniques. They used Rh catalysts supported on yttria-stabilized zirconia (YSZ) and $\mathrm{Al}_{2} \mathrm{O}_{3}$. They propose a detailed mechanism based on transient isotopic results:

$$
\begin{aligned}
& \mathrm{CH}_{4}+* \longrightarrow \mathrm{CH}_{4}^{*}-----(2.13 \mathrm{a}) \\
& \mathrm{CO}_{2}+* \longrightarrow \mathrm{CO}_{2}^{*}----(2.13 \mathrm{~b}) \\
& \mathrm{CH}_{4}{ }^{*}+(4-\mathrm{x})^{*} \longrightarrow \mathrm{CH}_{\mathrm{x}}{ }^{*}+(4-\mathrm{x}) \mathrm{H}^{*}----(2.13 \mathrm{c}) \\
& \mathrm{CH}_{\mathrm{x}}{ }^{*}+\mathrm{x}^{*} \longrightarrow \mathrm{C}^{*}+\mathrm{x} \mathrm{H}^{*}----(2.13 \mathrm{~d})
\end{aligned}
$$




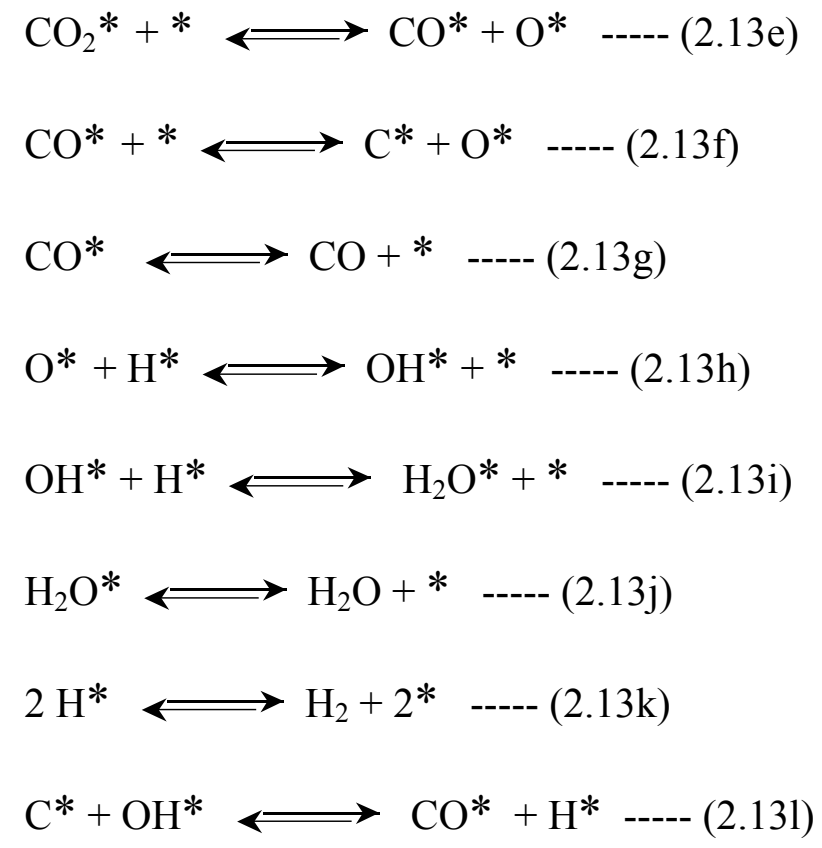

They conclude that steps $(2.13 \mathrm{a}),(2.13 \mathrm{c}),(2.13 \mathrm{~d})$, the backward step of $(2.13 \mathrm{f})$ and the forward step of (2.131) are relatively fast for $\mathrm{CO}$ production via the $\mathrm{CH}_{4}$ molecular pathway, as compared to that of $\mathrm{CO}_{2}$ [steps $(2.13 \mathrm{~b}),(2.13 \mathrm{e}),(2.13 \mathrm{f})$ and (2.131)]. This implies that sites that are occupied by $\mathrm{C}$-species derived from $\mathrm{CH}_{4}$ are of different nature than those from $\mathrm{CO}_{2}$, having different reactivity towards oxygen or $\mathrm{OH}$ species. Further, they also found no evidence for the dissociation of $\mathrm{CO}_{2}$ by hydrogen atoms, which is given by step (2.9c) reported earlier by Erdohelyi et al. (1993). Hence, this cannot be considered in the $\mathrm{CO}$ formation step. There was no indication of accumulation of atomic $\mathrm{O}$ species on the catalyst surface, which leads to the justification that, under reaction conditions, these $\mathrm{O}$ species must be more reactive than the $\mathrm{C}$ species to form gaseous $\mathrm{CO}$ and $\mathrm{H}_{2} \mathrm{O}$.

Luo et al. (2000) report that $\mathrm{C}-\mathrm{H}$ cleavages are the slow kinetic steps in $\mathrm{CO}_{2} / \mathrm{CH}_{4}$ reforming, based on their studies with $\mathrm{Ni}-\mathrm{La}_{2} \mathrm{O}_{3} / 5 \mathrm{~A}$ catalyst. These steps are as follows:

$$
\mathrm{CH}_{4} \longrightarrow \mathrm{C}+4 \mathrm{H}-----(2.14 \mathrm{a})
$$




$$
\begin{aligned}
& \mathrm{CH}_{\mathrm{x}}+\mathrm{O} \longrightarrow \mathrm{CO}+\mathrm{xH}^{-----}(2.14 \mathrm{~b}) \\
& \mathrm{CH}_{\mathrm{x}} \mathrm{O} \longrightarrow \mathrm{CO}+\mathrm{xH} \text {----- (2.14c) }
\end{aligned}
$$

From these steps, (2.14a) is found to be irreversible. Osaki et al. (1995, 1998), and later on Bradford and Vannice $(1999,1998)$, propose that the dissociation of $\mathrm{CH}_{\mathrm{x}} \mathrm{O}$ species to $\mathrm{CO}$ and $\mathrm{H}$ is rate determining. However, they do not provide any experimental evidences for the same. Nevertheless, in their $\mathrm{CH}_{4}-\mathrm{CO}_{2}$ pulsing experiments, Luo et al. (2000) observe that the deposited carbon from the $\mathrm{CH}_{4}$ reacts readily with $\mathrm{CO}_{2}$. The absence of $\mathrm{CH}_{\mathrm{x}}$ species on the catalyst surfaces indicates that the interaction of $\mathrm{CH}_{\mathrm{x}}$ species with surface oxygen is fast and hence step $(2.14 b)$ can be given as a combination of two steps as shown:

$$
\begin{aligned}
& \mathrm{CH}_{\mathrm{x}}+\mathrm{O} \longrightarrow \mathrm{CH}_{\mathrm{x}} \mathrm{O}-----(2.14 \mathrm{~d}) \\
& \mathrm{CH}_{\mathrm{x}} \mathrm{O} \longrightarrow \mathrm{CO}+\mathrm{x} \mathrm{H}-----(2.14 \mathrm{e})
\end{aligned}
$$

Consequently, they propose that step $(2.14 \mathrm{e})$ is rate determining. They went on to propose a series of mechanistic steps similar to that proposed by Efstathiou et al. (1996). The only addition is that of steps $(2.14 \mathrm{~d})$ and $(2.14 \mathrm{e})$ where $\mathrm{CH}_{\mathrm{x}} \mathrm{O}(\mathrm{x}=1$ or 2$)$ species are formed and dissociated to form surface $\mathrm{CO}$ and $\mathrm{H}$ atoms.

Recently, Claridge et al. (1998) report catalytic activity by high-surface-area molybdenum and tungsten carbide materials. They propose that there are two possible competing mechanisms for dry reforming.

(1) Cycling or redox mechanism:

After the dissociative adsorption of $\mathrm{CO}_{2}$, the $\mathrm{O}^{*}$ formed reacts with the carbon in the carbide surface $\left(\mathrm{C}_{\mathrm{s}}\right)$ to leave a vacancy $\left(^{[]}\right)$. This vacancy is then filled with either $\mathrm{C}^{*}$ 
from carbon adsorbed from methane, giving back the carbide, or with $\mathrm{O}^{*}$ to oxidize the metal carbide to form its oxide. These steps can be given as:

$$
\begin{aligned}
& \mathrm{CO}_{2}+* \longleftrightarrow \mathrm{CO}^{*} \mathrm{O}^{*}----(2.15 \mathrm{a}) \\
& \mathrm{WC}_{\mathrm{s}}+\mathrm{O}^{*} \rightleftarrows \mathrm{W}^{[]}+\mathrm{CO} \quad----(2.15 \mathrm{~b}) \\
& \mathrm{W}^{[]}+\mathrm{C}^{*} \rightleftarrows \mathrm{WC}_{\mathrm{s}}----(2.15 \mathrm{c}) \\
& \mathrm{W}^{[]}+\mathrm{O}^{*} \rightleftarrows \mathrm{WO} \text { (oxides) }----(2.15 \mathrm{~d})
\end{aligned}
$$

(2) Noble metal type mechanism:

The $\mathrm{O}^{*}$ reacts with the $\mathrm{C}^{*}$ formed from the dissociation of methane, instead of the carbon from the carbide. It can be given as:

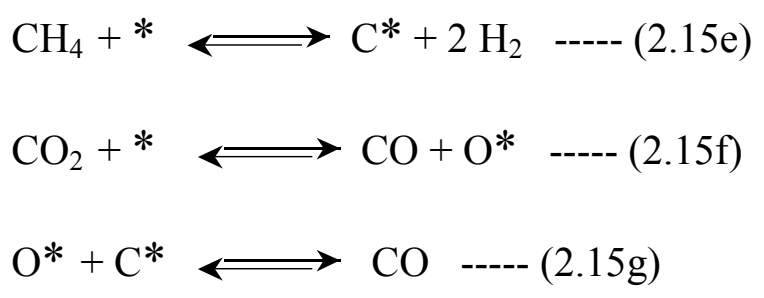

It is suggested that both the mechanisms are equally important for reforming reactions.

\subsubsection{Adsorption based kinetic models}

Methane reforming is not a simple set of independent reactions, but can be considered as a complex network of parallel reactions, which can be represented as follows (Mark et al., 1997):

$$
\begin{aligned}
& \mathrm{CH}_{4}+\mathrm{CO}_{2} \longleftrightarrow 2 \mathrm{CO}+2 \mathrm{H}_{2} \quad \text { (Dry reforming) ---- (2.16a) } \\
& \mathrm{CO}_{2}+\mathrm{H}_{2} \longleftrightarrow \mathrm{CO}+\mathrm{H}_{2} \mathrm{O} \text { (RWGS) ---- (2.16b) } \\
& \mathrm{CO}_{2}+4 \mathrm{H}_{2} \longleftrightarrow \mathrm{CH}_{4}+2 \mathrm{H}_{2} \mathrm{O} \text { (Methanation) ----- (2.16c) }
\end{aligned}
$$




$$
\begin{aligned}
& \mathrm{CH}_{4}+\mathrm{H}_{2} \mathrm{O} \rightleftarrows \mathrm{CO}+3 \mathrm{H}_{2} \quad \text { (Steam reforming) ----- }(2.16 \mathrm{~d}) \\
& \mathrm{CH}_{4} \rightleftarrows 2 \mathrm{H}_{2}+\mathrm{C} \quad \text { (Methane decomposition) } \\
& 2 \mathrm{CO} \rightleftharpoons \mathrm{CO}_{2}+\mathrm{C} \quad \text { (Boudouard reaction) } \\
& \mathrm{C}+\mathrm{H}_{2} \mathrm{O} \rightleftharpoons \mathrm{C} \text {---- }(2.16 \mathrm{f})
\end{aligned}
$$

However, not all the reactions, from this complex set of seven parallel reactions, are required to depict the whole reaction network. Only a few stoichiometrically independent reactions would suffice to describe the reaction system. Based on these kinetic studies some researchers have come up with a simple power-law rate expression as seen earlier in section 2.5.1. However, based on kinetic studies over a range of partial pressure data and the mechanistic schemes proposed, there have been a number of complex rate expressions which seem to follow the Langmiur-Hinshelwood, HougenWatson or Eley-Rideal type of rate expression. A detailed list of the rate expressions derived so far by various investigators in tabulated in Table 2.7 .

Lewis et al. (1949) presented some of the earliest reports of a Langmuir-type rate expression (eqn. 2.17) for methane dry reforming based on their studies with $\mathrm{Cu} / \mathrm{SiO}_{2}$ catalyst. However, they did not report any reaction mechanism from which they derived their rate expression. Also, they worked within a limited experimental regime. Consequently, they assumed that all the parameters are temperature independent except the rate constant. However, the reported heats of adsorption do depend on temperature, which makes the expression inconsistent. Bodrov and Apel'baum (1967) reported of kinetic studies of over a $\mathrm{Ni}$ foil and fitted their data to an expression given by eqn. 2.18. 
Table 2.7 Proposed rate expressions for dry reforming of methane with carbon dioxide.

\begin{tabular}{|c|c|c|c|}
\hline Eq. No. & Rate model & Catalyst & Reference \\
\hline 2.17 & $r_{r e f}=\frac{k_{r e f} P_{\mathrm{CH}_{4}}\left(P_{\mathrm{CO}_{2}}+P_{\mathrm{H}_{2} \mathrm{O}}\right)}{\left[1+24\left(P_{\mathrm{CO}_{2}}+P_{\mathrm{H}_{2} \mathrm{O}}\right)+8 P_{\mathrm{H}_{2}}\right]^{2}}$ & $\mathrm{Cu} / \mathrm{SiO}_{2}$ & Lewis et. al. (1949) \\
\hline 2.18 & $r_{r e f}=\frac{k_{r e f} P_{C H_{4}}}{1+a \frac{P_{\mathrm{H}_{2} \mathrm{O}}}{P_{\mathrm{H}_{2}}}+b P_{C O}}$ & $\mathrm{Ni}$ foil & Bodrov and Apel'baum (1967) \\
\hline 2.19 & $r_{\text {ref }}=\frac{k_{r e f} K_{\mathrm{CH}_{4}} K_{\mathrm{CO}_{2}} P_{\mathrm{CH}_{4}} P_{\mathrm{CO}_{2}}}{\left(1+K_{\mathrm{CH}_{4}} P_{\mathrm{CH}_{4}}+K_{\mathrm{CO}_{2}} P_{\mathrm{CO}_{2}}\right)^{2}}$ & $\mathrm{Rh} / \mathrm{Al}_{2} \mathrm{O}_{3}$ & $\begin{array}{l}\text { Richardson and Paripatyadar } \\
\text { (1990) }\end{array}$ \\
\hline 2.20 & $r_{r e f}=\frac{a P_{\mathrm{CH}_{4}} P_{C O_{2}}^{2}}{\left(a+b P_{C O_{2}}^{2}+c P_{\mathrm{CH}_{4}}\right)^{2}}$ & $\begin{array}{l}\mathrm{Ni} / \mathrm{Al}_{2} \mathrm{O}_{3} \\
\mathrm{Ni} / \mathrm{CaO}-\mathrm{Al}_{2} \mathrm{O}_{3}\end{array}$ & Zhang and Verykios (1994) \\
\hline 2.21 & $r_{r e f}=\frac{k_{r e f}\left(P_{\mathrm{CH}_{4}}-\frac{P_{\mathrm{H}_{2}}^{2} P_{\mathrm{CO}}^{2}}{K_{r e f} P_{\mathrm{CO}_{2}}}\right)}{1+\frac{P_{\mathrm{CO}}^{2}}{K_{R, \mathrm{C}-z} P_{\mathrm{CO}_{2}}}}$ & $\mathrm{Ir} / \mathrm{Al}_{2} \mathrm{O}_{3}$ & Mark and Maier (1996) \\
\hline 2.22 & $r_{r e f}=\frac{k_{r e f} K_{\mathrm{CH}_{4}}\left(P_{\mathrm{CH}_{4}} P_{\mathrm{CO}_{2}}-\frac{P_{\mathrm{H}_{2}}^{2} P_{\mathrm{CO}}^{2}}{K_{r e f}}\right)}{1+K_{\mathrm{CH}_{4}} P_{\mathrm{CH}_{4}}}$ & $\mathrm{Ir} / \mathrm{Al}_{2} \mathrm{O}_{3}$ & Mark et al. (1997) \\
\hline
\end{tabular}




\begin{tabular}{|c|c|c|c|}
\hline 2.23 & $r_{r e f}=\frac{k_{r e f} K_{\mathrm{CO}_{2}}\left(P_{\mathrm{CH}_{4}} P_{\mathrm{CO}_{2}}-\frac{P_{\mathrm{H}_{2}}^{2} P_{\mathrm{CO}}^{2}}{K_{r e f}}\right)}{1+K_{\mathrm{CO}_{2}} P_{\mathrm{CO}_{2}}}$ & $\mathrm{Ir} / \mathrm{Al}_{2} \mathrm{O}_{3}$ & Mark et al. (1997) \\
\hline 2.24 & $r_{r e f}=\frac{k_{r e f} K_{\mathrm{CH}_{4}} K_{\mathrm{CO}_{2}}\left(P_{\mathrm{CH}_{4}} P_{\mathrm{CO}_{2}}-\frac{P_{\mathrm{H}_{2}}^{2} P_{\mathrm{CO}}^{2}}{K_{r e f}}\right)}{\left(1+K_{\mathrm{CH}_{4}} P_{\mathrm{CH}_{4}}+K_{\mathrm{CO}_{2}} P_{\mathrm{CO}_{2}}\right)^{2}}$ & $\mathrm{Ir} / \mathrm{Al}_{2} \mathrm{O}_{3}$ & Mark et al. (1997) \\
\hline 2.25 & $r_{r e f}=\frac{k_{r e f} P_{\mathrm{CH}_{4}} P_{\mathrm{CO}_{2}}}{\left(1+K_{1} P_{\mathrm{CH}_{4}}+K_{2} P_{\mathrm{CO}}\right)\left(1+K_{3} P_{\mathrm{CO}_{2}}\right)}$ & $\mathrm{Ni} / \mathrm{La} / \mathrm{Al}_{2} \mathrm{O}_{3}$ & Olsbye et al. (1997) \\
\hline 2.26 & $r_{r e f}=\frac{k_{r e f} \sqrt{K_{1} K_{2} P_{\mathrm{CH}_{4} P_{\mathrm{CO}_{2}}}}}{\left(1+\sqrt{K_{1} P_{\mathrm{CH}_{4}}}+\sqrt{K_{2} P_{\mathrm{CO}_{2}}}\right)^{2}}$ & $\begin{array}{l}\mathrm{Ni} / \mathrm{Al}_{2} \mathrm{O}_{3}, \mathrm{Ni} / \mathrm{SiO}_{2} \\
\mathrm{Ni} / \mathrm{CaO}-\mathrm{Al}_{2} \mathrm{O}_{3}\end{array}$ & Osaki et al. (1997) \\
\hline 2.27 & $r_{C H_{4}}=\frac{k_{3} K_{1} K_{2} P_{C_{H}} P_{C_{2}} P_{C O} P_{H_{2}}^{2}}{\left(P_{C O} P_{H_{2}}^{2}+K_{1} P_{C_{4}} P_{C O}+K_{2} P_{C O_{2}} P_{H_{2}}^{2}\right)^{2}}$ & $\mathrm{Ni} / \mathrm{SiO}_{2}$ & Kroll et al. (1998) \\
\hline 2.28 & $r_{\mathrm{CH}_{4}}=\frac{k_{1} P_{\mathrm{CH}_{4}} P_{\mathrm{CO}_{2}}}{\left(\frac{k_{-1} K}{k_{7}}\right) P_{\mathrm{CO}} P_{\mathrm{H}_{2}}^{\frac{(4-x)}{2}}+\left(1+\left(\frac{k_{1}}{k_{7}}\right) P_{\mathrm{CH}_{4}}\right) P_{\mathrm{CO}_{2}}}$ & $\begin{array}{l}\text { Supported } \\
\mathrm{Pt} \text { and } \mathrm{Ni}\end{array}$ & Bradford and Vannice (1998) \\
\hline 2.29 & $r_{r e f}=\frac{k_{r e f} P_{\mathrm{CH}_{4}} P_{\mathrm{CO}_{2}}}{\left(1+K_{\mathrm{CH}_{4}} P_{\mathrm{CH}_{4}}\right)\left(1+K_{\mathrm{CO}_{2}} P_{\mathrm{CO}_{2}}\right)}$ & $\begin{array}{l}\mathrm{Ni} / \mathrm{Al}_{2} \mathrm{O}_{3} \\
\mathrm{Ni} / \mathrm{CeO}_{2}-\mathrm{Al}_{2} \mathrm{O}_{3}\end{array}$ & Wang et al. (2000) \\
\hline
\end{tabular}


Richardson and Paripatyadar (1990) studied the $\mathrm{CO}_{2} / \mathrm{CH}_{4}$ reforming kinetics over $\mathrm{Rh} / \mathrm{Al}_{2} \mathrm{O}_{3}$ catalyst and report a rate expression (eqn. 2.19), based on a LangmuirHinshelwood approach involving redox mechanisms. Calculated and measured values correlate well with a regression coefficient of 0.988 . However, they do not present the mechanistic basis for their expression and their adsorption constants do not satisfy some of the guidelines given by Vannice et al. (1979) and Lee (1985).

Zhang and Verykios (1994) propose a rate expression (eqn. 2.20) derived from a Langmuir-type model, assuming methane dissociation is the rate-determining step. Although the model fits the observed data well, Zhang and Verykios did not provide any values for the adsorption and kinetic parameters.

In previous work, Mark and Maier (1996) propose a step-wise kinetic model (eqn. 2.21) where $\mathrm{CH}_{4}$ dissociation to active carbon is assumed to be the rate-determining step. This model was derived based on three independent reactions (eqn. 2.16b, 2.16e, 2.16f). The model leads to a good fit of observed data and the physical parameters are consistent with those reported in literature. However, carbon formation and catalyst deactivation have been neglected in this analysis. Besides, this kinetic model is valid only for stoichiometric feed compositions and would require a rigorous analysis for different feed ratios.

Mark et al. (1997) investigated the kinetics of $\mathrm{CO}_{2} / \mathrm{CH}_{4}$ reforming with $\operatorname{Ir} / \mathrm{Al}_{2} \mathrm{O}_{3}$ catalyst over a temperature range of $700-850{ }^{\circ} \mathrm{C}$. They consider the Eley-Rideal (ER) and Langmuir-Hinshelwood (LH) type of heterogeneous models. The ER model given by eqn. 2.22 assumes that $\mathrm{CH}_{4}$ is adsorbed on the catalyst surface and is in equilibrium. The slow and rate-determining step is the reaction of this adsorbed species with the other 
reactant $\left(\mathrm{CO}_{2}\right)$ in the gas phase, leading directly to products in the gas phase. As both reactants can theoretically be adsorbed, the other ER model (eqn. 2.23) considers the adsorption of $\mathrm{CO}_{2}$ on the catalyst surface and the rate-determining step is the surface reaction of this adsorbed species with $\mathrm{CH}_{4}$ in the gas phase. However, the $\mathrm{LH}$ model (eqn. 2.24) considers the adsorption of both the reactants and is similar to the one proposed by Richardson and Paripatyadar (1990) (eqn. 2.19). Both ER and LH models give positive adsorption enthalpies, which is inconsistent with literature. However, Mark et al. attribute this discrepancy to their integral method of operation with high conversions, and to the broader experimental temperature range of $700-850{ }^{\circ} \mathrm{C}$.

Olsbye et al. (1997) have reported the kinetic studies of $\mathrm{CO}_{2} / \mathrm{CH}_{4}$ reforming over a highly active $\mathrm{Ni} / \mathrm{La} / \mathrm{Al}_{2} \mathrm{O}_{3}$ catalyst in a micro-catalytic fixed-bed reactor. The reaction temperature was varied between $700-900{ }^{\circ} \mathrm{C}$, while the reactant partial pressures ranged from 16 to $40 \mathrm{kPa}$. The proposed Langmuir-Hinshelwood type rate expression is given by eqn. 2.25 (Table 2.8). The observed kinetic data were found to be in fairly good agreement with the predicted rate model. The model was validated with a laboratoryscale fluidized-bed reactor. However, Olsbye et al. did not present the reaction mechanism from which the model was proposed. Osaki et al. (1997) have presented a kinetic model for $\mathrm{CO}_{2} / \mathrm{CH}_{4}$ reforming over various supported nickel catalysts (eqn. 2.26). Nevertheless, the values for adsorption and kinetic parameters are not presented.

Kroll et al. (1998) have investigated the dry-reforming kinetics over $\mathrm{Ni} / \mathrm{SiO}_{2}$ catalyst, and have proposed a Langmuir-type rate expression (eqn 2.27). The ratedetermining step assumed is the surface reaction between the adsorbed surface carbon and oxygen adspecies. The model was validated statistically with experimental results 
obtained at $700{ }^{\circ} \mathrm{C}$. However, the activation energies as well as the heats of adsorption could not be determined, due to lack of experimental data for a broad range of temperatures.

Bradford and Vannice $(1996,1998)$ report of a kinetic model (eqn 2.28) for $\mathrm{CO}_{2} / \mathrm{CH}_{4}$ reforming over a range of supported $\mathrm{Pt}$ and $\mathrm{Ni}$ catalysts. Their model is well supported by a reaction mechanism, which is based on $\mathrm{CH}_{4}$ activation to form $\mathrm{CH}_{\mathrm{x}}$ and decomposition of $\mathrm{CH}_{\mathrm{x}} \mathrm{O}$ as the rate-determining step. The model successfully describes the reaction kinetics with meaningful values of adsorption and kinetic parameters. The model does not incorporate carbon deposition, which is observed for reactions with $\mathrm{Ni}$ catalysts. However, their mechanism is applicable to only those catalysts, which inhibit carbon formation within their experimental conditions. Thus, the kinetic data for the modeling was obtained by restricting the operating conditions to a low-temperature regime where carbon formation is thermodynamically unfavorable.

Wang et al. (2000) have proposed a simple reaction mechanism along with a LHtype kinetic model (eq. 2.29) for methane dry reforming with unpromoted and ceria promoted $\mathrm{Ni} / \mathrm{Al}_{2} \mathrm{O}_{3}$ catalysts. However, the model does not incorporate the competitive adsorption between $\mathrm{CH}_{4}$ and $\mathrm{CO}_{2}$ molecules for the active sites on the catalyst surface. Besides, the carbon deposition and the RWGS reactions are not incorporated in the proposed mechanism. 


\section{CHAPTER 3}

\section{EXPERIMENTAL SETUP AND PROCEDURE}

\subsection{Equipment description}

The catalyst-testing unit is as shown in Figure 3.1 and is similar to that used by Liu et al. (1997). The entire system is computer controlled using a commercial software package, InTouch by Wonderware. Most of the operating conditions can be set directly from the computer, the exception being the reactor pressure, which has to be adjusted manually by using the back-pressure regulator. The computer logs in data automatically at operator-determined intervals. The unit is designed to operate up to a pressure of 1500 psig.

The unit has four lines for gas feeds, each being independently controlled by a Brooks mass-flow controller (model No. 5850E), manufactured by Brooks Instruments. The reactor consists of a silica-lined stainless-steel tube (SS 304L) of nominal outer diameter of $13 \mathrm{~mm}$ (0.5 in.) and nominal length of $0.6 \mathrm{~m}$ (25 in.), placed in a $0.45 \mathrm{~m}$ (18 in.) single-zone furnace from Applied Test Systems. The silica lining on the stainlesssteel reactor tube was applied at Restek Corp. The catalyst is placed in the center of the reactor, with the quartz chips placed upstream and downstream of the catalyst. The product stream is sampled immediately downstream using a six-port external-volume gas-sampling valve manufactured by Valco Instruments Co. Inc. and is as shown in Figure 3.2. The valve is set at the operating pressure of the reactor and a minimum temperature of $100{ }^{0} \mathrm{C}$. 


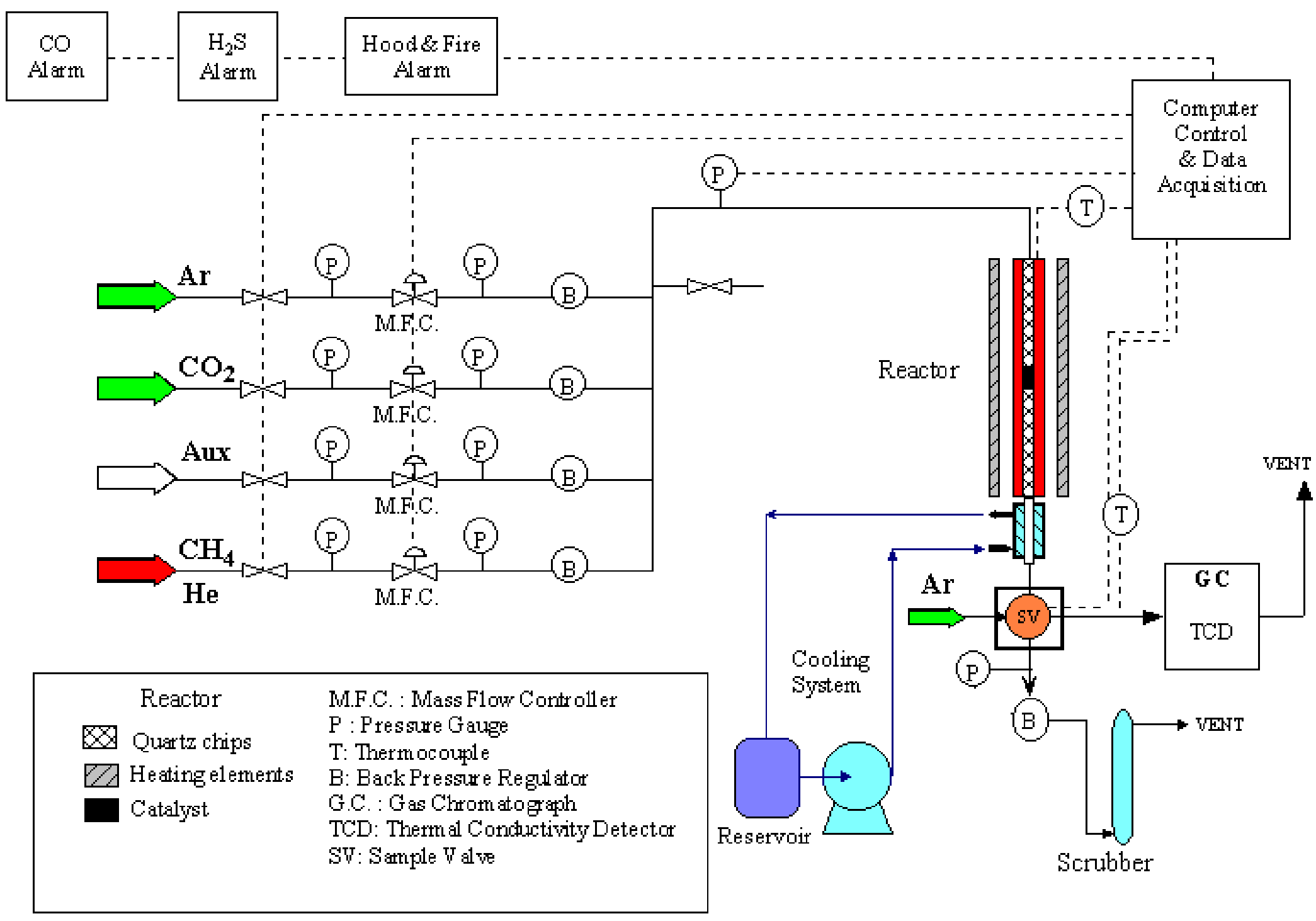

Figure 3.1. Flowsheet of the catalyst-testing unit. 
There is a cooling system between the reactor outlet and the sampling valve, to prevent the hot flue gases from heating up the valve to a temperature beyond its operating range. The exit gas stream from the sampling loop is passed through a back-pressure regulator obtained from GO Inc (model $\mathrm{P} / \mathrm{N}$ 101182) with an operating range $0-2000$ psig. This back-pressure regulator is used to maintain the reactor pressure. Stainless-steel tubing of nominal outer diameter of $1 / 4$ " and Swagelok end connections are used in the entire network of gas lines of the catalyst-testing unit. The pressure in the reactor is monitored by a Sensotec pressure transducer (model No. THE/743-01) with an operating range of $0-2000 \mathrm{psig}$. The pressure gauges in the range of 0-400 psig are obtained from Omega Engineering Inc. (model No. 238A460-01 REV.E). A 1/16" nominal diameter and 18" nominal length with an inconel sheath ungrounded K-type thermocouple (model CAIN-116U-18) is used to monitor the reaction temperature.
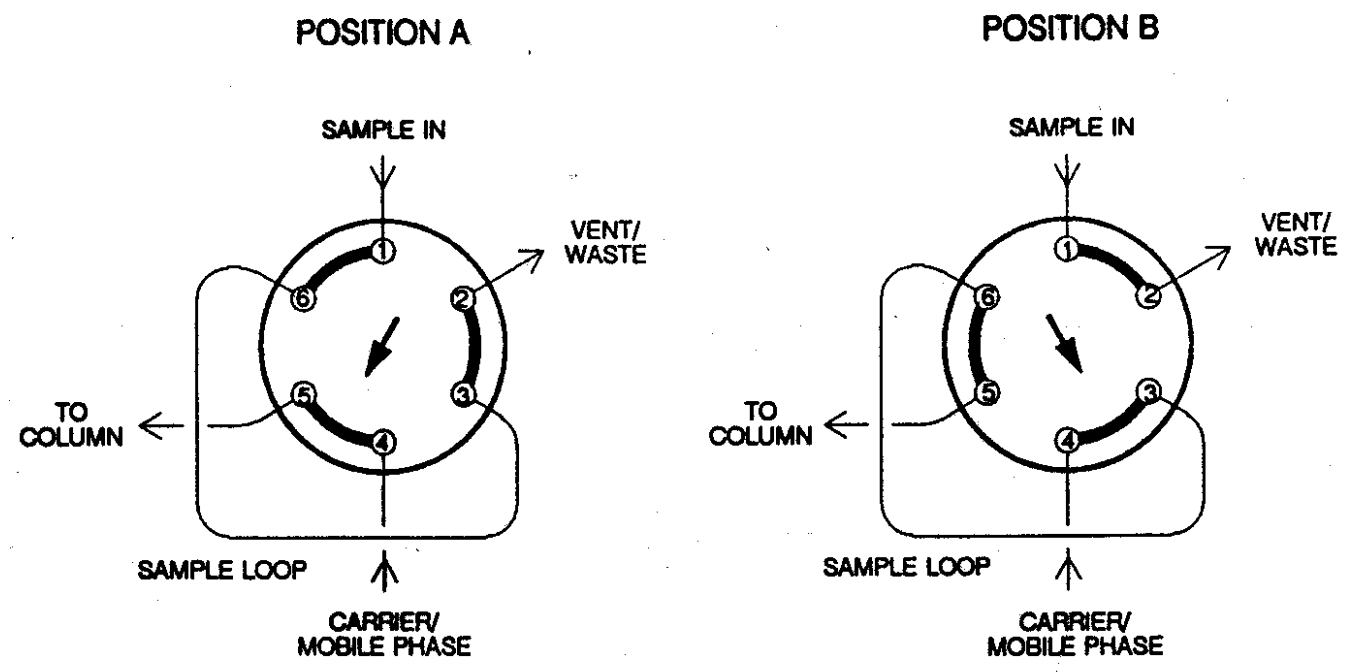

Figure 3.2. Schematic flow diagram of two position six-port external volume sample injector (Valco Instruments Co. Inc.). 
The products are analyzed on-line by a Hewlett-Packard 5890 gas chromatograph (GC) using two columns and two detectors in parallel. The GC is controlled using Hewlett-Packard (HP) Chemstation software by the same computer in a multitasking MS Windows environment. In the $\mathrm{GC}$, the flow is split between the two columns: a HayeSep-DB packed column, $9 \mathrm{~m} \times 3.1 \mathrm{~mm}(30 \mathrm{ft} \times 1 / 8 \mathrm{in}$.), and a J\&W DBWax capillary column, $20 \mathrm{~m} \times 0.1 \mathrm{~mm}$ i.d. The oven temperature for both the columns is maintained isothermal at $150{ }^{\circ} \mathrm{C}$. The details of the $\mathrm{GC}$ operating conditions are given in Appendix A. The packed column is connected to a thermal-conductivity detector (TCD), which provides quantitative analysis for $\mathrm{He}, \mathrm{H}_{2}, \mathrm{CO}, \mathrm{CH}_{4}, \mathrm{CO}_{2}$ and $\mathrm{H}_{2} \mathrm{O}$. Helium is used as the internal standard while argon serves as the carrier gas. The gas mixtures of $\mathrm{CH}_{4} / \mathrm{He}, \mathrm{CO}_{2}$, Ar, $\mathrm{CO}$ and $\mathrm{H}_{2}$ were obtained from Airgas. The capillary column is connected to a flame-ionization detector (FID) used to detect if any other products like oxygenates are being produced in the reaction. The GC feed line from the sampling loop is maintained at a temperature of $150{ }^{0} \mathrm{C}$ by wrapping the line with heating tapes. Besides, all the sections of the tubings between the exit of the reactor and the inlet of the sample loop are maintained at $150{ }^{\circ} \mathrm{C}$ by wrapping them with heating tapes. These modifications prevent the water in the product stream from condensing before reaching the GC inlet and the sampling loop respectively. The reactor effluent (vapor phase) that is not passed through the GC is vented after passing through a scrubber.

The entire unit is located in a walk-in hood. The computer continuously monitors alarms for $\mathrm{CO}$ and for flows of reactive gases, hood velocity, ambient hood temperature, reactor temperature, reactor pressure and electric power. The unit automatically shuts 
down in the event of hood failure, fire, power and air supply failure, or $\mathrm{CO}$ leak detection or if the gas flows or reactor temperature exceed any of the preset operating ranges.

\subsection{Experimental procedure}

\subsubsection{Reactor loading}

The silica-lined stainless-steel reactor tube is cleaned and dried thoroughly prior to each loading. Typically, about $300 \mathrm{mg}$ of the catalyst is loaded in the reactor for each run. The catalyst bed comprises of the catalyst, carefully embedded between two stubs of quartz wool. The thermocouple is carefully inserted in the reactor such that the tip of the thermocouple just touches the catalyst bed. The upstream and downstream of the catalyst bed are then loaded with quartz chips. Typically, about $52 \mathrm{~g}$ of quartz chips are used for each loading. The fresh quartz chips consist of a coating of quartz fines. If the quartz chips are loaded prior to washing, these quartz fines plug the reactor when the gas-flow through the reactor begins. On washing and drying the quartz chips, the coating of quartz fines is removed. Hence, these chips have to be washed and dried prior to use to prevent quartz fines from plugging the reactor. The loaded reactor is then sealed with quartz wool at the bottom and is then mounted in the setup with the furnace enclosure. A thin even coating of "SAF-T-EZE", a copper anti-seize and lubricant, is applied on all the threaded parts of the reactor system. It is ensured that no lubricant drips on the ferrules of the fittings, as this might cause contamination in the system. The system is then checked for leaks by flowing an inert gas (Ar) at $95 \mathrm{psig}$ and room temperature. During the testing of the reactor activity (blank run), the reactor was loaded as stated above, except that there was no catalyst placed in catalyst bed. 


\subsubsection{Pretreatment and Reaction}

The catalyst pretreatment is then carried out by flowing hydrogen at $400{ }^{\circ} \mathrm{C}$ for 1 hour at atmospheric pressure. The outlet stream is passed through a scrubber to prevent any chance of hydrogen accumulation into the hood and to avoid the hydrogen concentration from reaching the lower explosive limit. The GC is switched on only after ensuring the flow of the carrier gas through the column and TCD. After the pretreatment, the reaction is started by adjusting the required flows of the feed gases and setting the required temperatures with the aid of the computer. However, the reaction pressure has to be set manually, by means of the back-pressure regulator. The cooling system is set at a temperature range between $30-50{ }^{0} \mathrm{C}$ so that the temperature of the sample loop is maintained at a constant temperature. The liquid level in the reservoir of the cooling system is monitored at regular intervals. The computer can be preset to inject samples into the GC at specified time intervals. The HP Chemstation software is used to analyze the injected samples for $\mathrm{He}, \mathrm{H}_{2}, \mathrm{CO}, \mathrm{CH}_{4}, \mathrm{CO}_{2}$ and $\mathrm{H}_{2} \mathrm{O}$ peaks detected by the TCD. The software is preset for a certain GC analysis period. For all the runs, the analysis time was fixed for a period of fifteen minutes after prior calibration and optimization.

\subsubsection{Calibration of mass flow controllers}

The catalyst-testing unit (Figure 3.1) has four lines for gas feed, each being independently controlled by a Brooks mass-flow controller (MFC). Each of the MFCs was pre-assigned to a specific feed gas except the one, labeled "Aux" (Figure 3.1), where $\mathrm{CO}$ and $\mathrm{H}_{2}$ were used consecutively when required. The room temperature was maintained constant at $21{ }^{\circ} \mathrm{C}$ during the entire calibration process. The MFCs were 
enclosed in an insulated Styrofoam container to minimize the effects of room temperature changes on the calibration process. The gas flow rate was preset to the maximum set value on the MFC and the system was allowed to reach a steady state. The flow at the outlet was then measured using a bubble flow meter. The readings were repeated similarly for other set values and a calibration curve was obtained (Appendix C). These calibrations were performed periodically, prior to every experiment and at the same operating pressures as that of the reaction conditions.

\subsubsection{GC calibration of the gas species}

The products are analyzed on-line by a Hewlett-Packard 5890 gas chromatograph (GC), which provides quantitative analysis for $\mathrm{He}, \mathrm{H}_{2}, \mathrm{CO}, \mathrm{CH}_{4}, \mathrm{CO}_{2}$ and $\mathrm{H}_{2} \mathrm{O}$. All the species except $\mathrm{H}_{2} \mathrm{O}$ are calibrated by automatically injecting the known sample in the loop using the auto-injector (Figure 3.2). These samples were injected through the injection port A. The temperature of the loop, the pressure in the loop and the loop volume were noted during the analysis. $\mathrm{H}_{2} \mathrm{O}$ was calibrated by injecting known liquid volumes through the injection port B, using a Hamilton micro-liter syringe. The details of the calculation and the calibration curves are presented in Appendix B, while the GC operating conditions are presented in Appendix A. The thermal-conductivity detector was used primarily for all the calibrations. These calibrations were performed periodically, prior to every experiment. 


\subsubsection{Characterization}

The Brunauer-Emmett-Teller (BET) surface area measurements were performed by Professor Edwin Kugler of the Department of Chemical Engineering, West Virginia University (WVU), Morgantown. The X-ray diffraction (XRD) analysis was performed by Professor Mohindar Seehra of the Department of Physics, WVU. The scanning electron microscope (SEM) analysis was carried out by Dr. William Chisholm of the National Institute of Occupational Safety and Health (NIOSH), Morgantown.

\subsubsection{Safety Requirements}

The safety requirements are continuously reviewed. Major areas of concern are operating at high temperatures; toxicity of the chemicals; flammability of methane, hydrogen and carbon monoxide; and mechanical and electrical connections.

As operating conditions are as high as $850{ }^{\circ} \mathrm{C}$, safety goggles are used while working near the equipment in operation. Latex gloves are used while handling equipment or chemicals. As methane, hydrogen and carbon monoxide are extremely flammable, any source of sparks or fire near the working area is avoided. The computer continuously monitors alarms for $\mathrm{CO}$ and for flows of reactive gases, hood velocity, ambient hood temperature, reactor temperature, reactor pressure and electric power. The unit automatically shuts down in the event of hood failure, fire, power and air supply failure, or $\mathrm{CO}$ leak detection, or if the gas flows or reactor temperature exceed any of the preset operating ranges. 
The laboratory is equipped with chemical hoods, fire extinguishers, chemical safety showers, chemical spill kit and eye wash stations. Other available equipment includes thermal gloves, dust masks, face shields, protective clothing and safety goggles. Material Safety Data Sheets (MSDS) have been obtained for all chemicals used in the laboratory, and are placed at the lab entrance for rapid access in case of emergency. A list of people to contact and the hazard ratings are posted at the entrance to the laboratory. Specific emergency procedures are placed near all the equipments to direct the shut down in case of emergency. 


\section{CHAPTER 4}

\section{RESULTS WITH SUPPORTED}

\section{NICKEL AND PLATINUM CATALYSTS}

\subsection{Introduction}

The purpose of the preliminary study with the commercial nickel catalyst was to validate the working conditions of the catalyst-testing unit. The second part of this preliminary investigation was to prepare and test the activity of zirconia-supported platinum catalyst. Consequently, the unit was made completely functional prior to testing of the carbide catalyst, which was the primary focus of this research study, except that an untreated stainless-steel reactor was used. Blank runs were performed as explained in section 3.2.1. The conditions for the blank runs were maintained identical to those of the actual reaction conditions used in this part of the study. Results show that the reactor and thermocouple system were not catalytically active up to $750{ }^{0} \mathrm{C}$. Hence, no correction was required in all the subsequent calculations as the maximum reaction temperature for all the experiments was $700{ }^{\circ} \mathrm{C}$. Further, an internal standard was not used in this part of the investigation. However, all the calculations were based on the volumetric flow rate measured at the reactor outlet by a bubble flow meter. 


\subsection{Commercial $\mathrm{Ni} / \mathrm{Al}_{2} \mathrm{O}_{3}$ catalyst}

\subsubsection{Materials and Methodology}

The commercial $\mathrm{Ni} / \mathrm{Al}_{2} \mathrm{O}_{3}$ catalyst was obtained from United Catalyst, Inc (currently Sud-Chemie). The $\mathrm{Ni} / \mathrm{Al}_{2} \mathrm{O}_{3}$ catalyst obtained has a BET surface area of 1.5-5 $\mathrm{m}^{2} / \mathrm{g}$ and pore volume of $0.1-0.2 \mathrm{cc} / \mathrm{g}$. It contains $14 \%$ wt. $\mathrm{Ni}, 80-86 \%$ wt. $\mathrm{Al}_{2} \mathrm{O}_{3}$, and less than $0.1 \%$ wt. C (supplied by United Catalyst, Inc). The catalyst pellets were crushed and sieved into grains of 0.3-0.6 mm (10-20 mesh) and 90-125 $\mu \mathrm{m}(120-170$ mesh) in size. Typically, $300 \mathrm{mg}$ of the catalyst was tested in each run. The catalyst was pretreated (as recommended by United Catalyst, Inc.) by heating to $149{ }^{\circ} \mathrm{C}$ and holding for 2 hours. The temperature was then raised to $204{ }^{\circ} \mathrm{C}$ and $\mathrm{CO}_{2}$ gas was passed through the reactor for 1 hour, before adjusting the reaction temperature to the desired value. The feed ratio used was $\mathrm{CH}_{4}: \mathrm{CO}_{2}: \mathrm{Ar}=1: 3.7: 4.9$, with a total feed rate of $170 \mathrm{scc} / \mathrm{min}$. The total pressure in the system was maintained at $1 \mathrm{~atm}$.

Both small and large particle size catalysts were tested at various reaction temperatures ranging from high temperature $\left(700{ }^{\circ} \mathrm{C}\right)$ to low temperature $\left(350{ }^{\circ} \mathrm{C}\right)$ with increasing and decreasing temperature modes. The reaction temperature was progressively raised in increments of $25{ }^{\circ} \mathrm{C}$, starting from an initial temperature of $350{ }^{\circ} \mathrm{C}$ up to a final temperature of $700{ }^{\circ} \mathrm{C}$. Subsequently, the reaction system was kept overnight in an inert atmosphere, flowing at $25 \mathrm{scc} / \mathrm{min}$. The temperature was maintained constant at $700{ }^{\circ} \mathrm{C}$. Later on, the feed mixture was introduced into the reaction system. The reaction temperature of the reaction-mixture system was then progressively lowered in decrements of $25{ }^{\circ} \mathrm{C}$, until the temperature of $350{ }^{\circ} \mathrm{C}$ was obtained. The reaction temperature was held constant for 1 hour after every $25{ }^{\circ} \mathrm{C}$ 
increment or decrement, and the product samples from the downstream of the reactor were analyzed on-line.

\subsubsection{Results and Discussion}

\section{Effect of reaction temperature}

The values of $\mathrm{CH}_{4}$ and $\mathrm{CO}_{2}$ conversions for the increasing and decreasing temperature cycles with $90-125 \mu \mathrm{m}$ particle sizes are as shown in Figures 4.1 and 4.2. The details of the calculation procedure for the conversions are given in Appendix D. It is interesting to note that most of the values of the conversions for the decreasing temperature cycles are higher than those values for the increasing ones. This can be attributed to the stabilization of the fresh catalyst by the opening up of the porous structure within. It is also found that subsequent temperature cycle runs yield similar conversions as that obtained for the first decreasing temperature cycle, after starting with the fresh catalyst. However, for temperatures below $550{ }^{\circ} \mathrm{C}$, the conversions in the decreasing temperature cycle are lower than those are for the increasing ones. This could be attributable to the catalyst deactivation that might be occurring due to coke deposition at higher temperatures (Wang and $\mathrm{Lu}, 2000$ ).

As the feed ratio used was $\mathrm{CH}_{4}: \mathrm{CO}_{2}=1: 3.7, \mathrm{CH}_{4}$ is the limiting reactant in the feed. Hence, the $\mathrm{CH}_{4}$ conversions are significantly higher than those of $\mathrm{CO}_{2}$. Figures 4.3 and 4.4 show the conversion profiles for decreasing temperatures using two different particle sizes of the catalyst. At $700{ }^{\circ} \mathrm{C}$, the $\mathrm{CH}_{4}$ and $\mathrm{CO}_{2}$ conversions for a particle size range of $90-125 \mu \mathrm{m}$ are $96 \%$ and $44 \%$ respectively. However, for the larger particle 


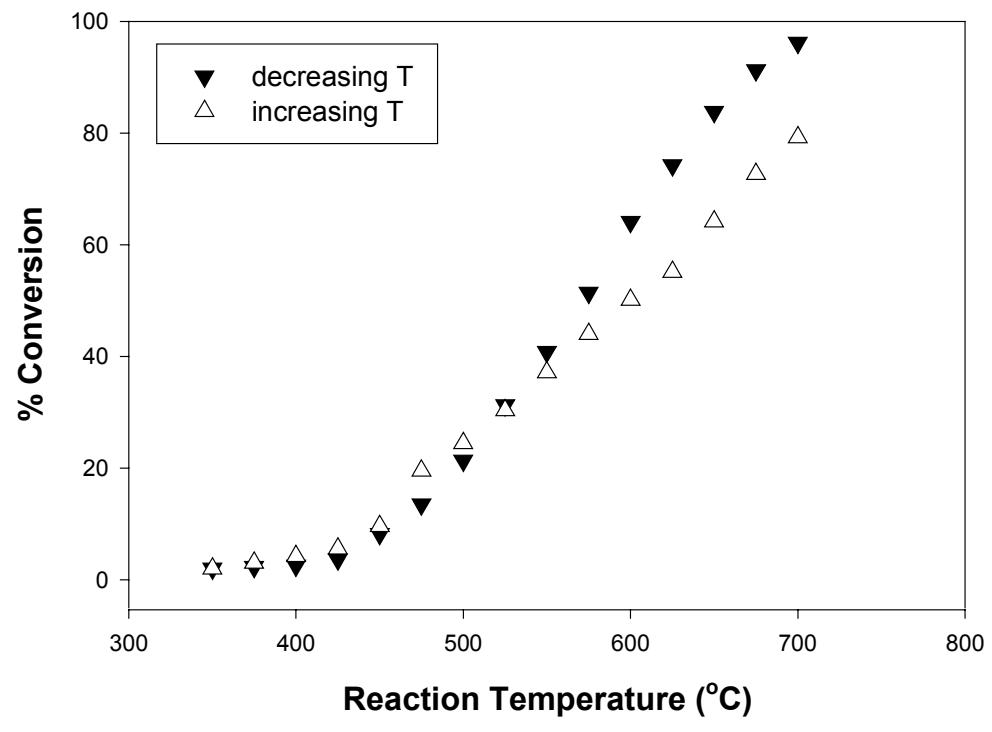

Figure 4.1 Effect of reaction temperatures cycles on $\mathrm{CH}_{4}$ conversion over $\mathrm{Ni} / \mathrm{Al}_{2} \mathrm{O}_{3}$ catalyst. (Particle size 90-125 $\mu \mathrm{m}, \mathrm{CH}_{4} / \mathrm{CO}_{2} / \mathrm{Ar}=1 / 3.7 / 4.9$, total feed rate: 170 $\mathrm{scc} / \mathrm{min})$

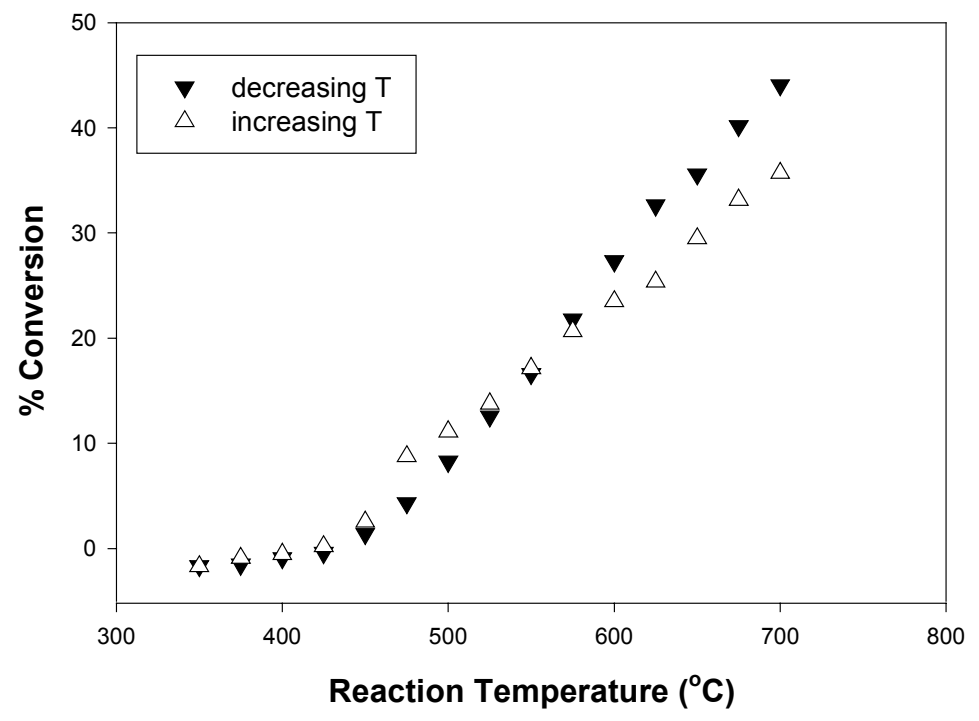

Figure 4.2 Effect of reaction temperatures cycles on $\mathrm{CO}_{2}$ conversion over $\mathrm{Ni} / \mathrm{Al}_{2} \mathrm{O}_{3}$ catalyst. (Particle size 90-125 $\mu \mathrm{m}, \mathrm{CH}_{4} / \mathrm{CO}_{2} / \mathrm{Ar}=1 / 3.7 / 4.9$, total feed rate: 170 sce/min) 


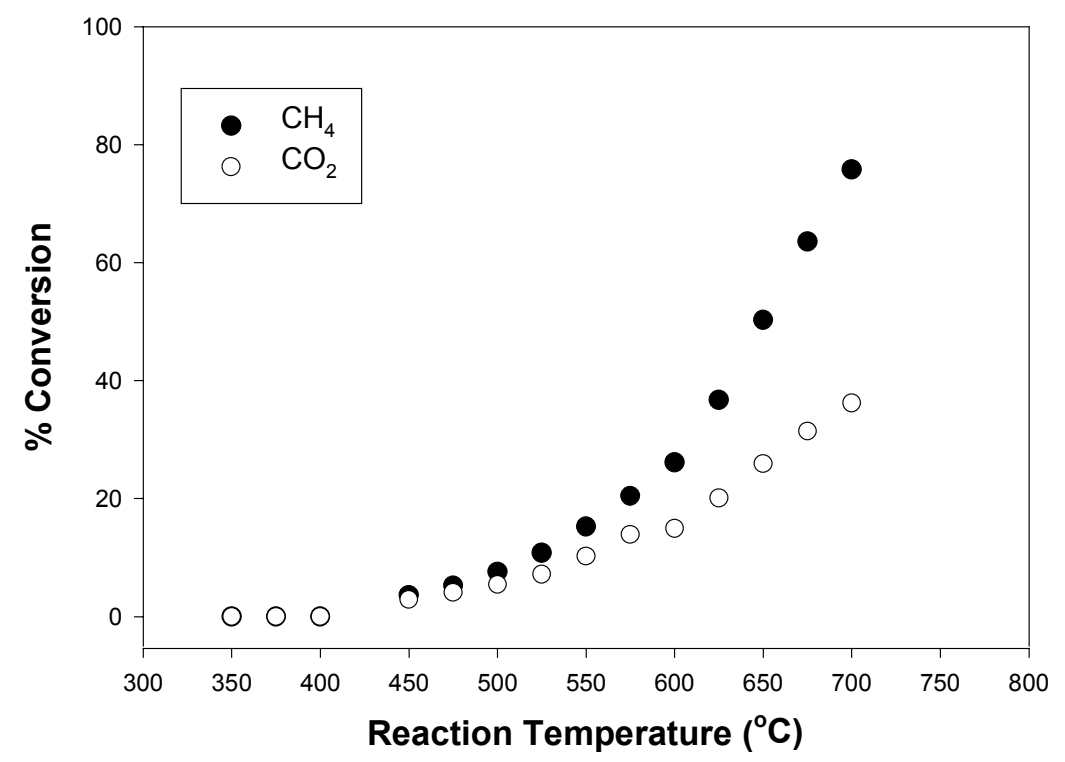

Figure 4.3 Effect of reaction temperatures on the activity over $\mathrm{Ni} / \mathrm{Al}_{2} \mathrm{O}_{3}$ catalyst. (Particle size 300-600 $\mu \mathrm{m}, \mathrm{CH}_{4} / \mathrm{CO}_{2} / \mathrm{Ar}=1 / 3.7 / 4.9$, total feed rate: $170 \mathrm{scc} / \mathrm{min}$ )

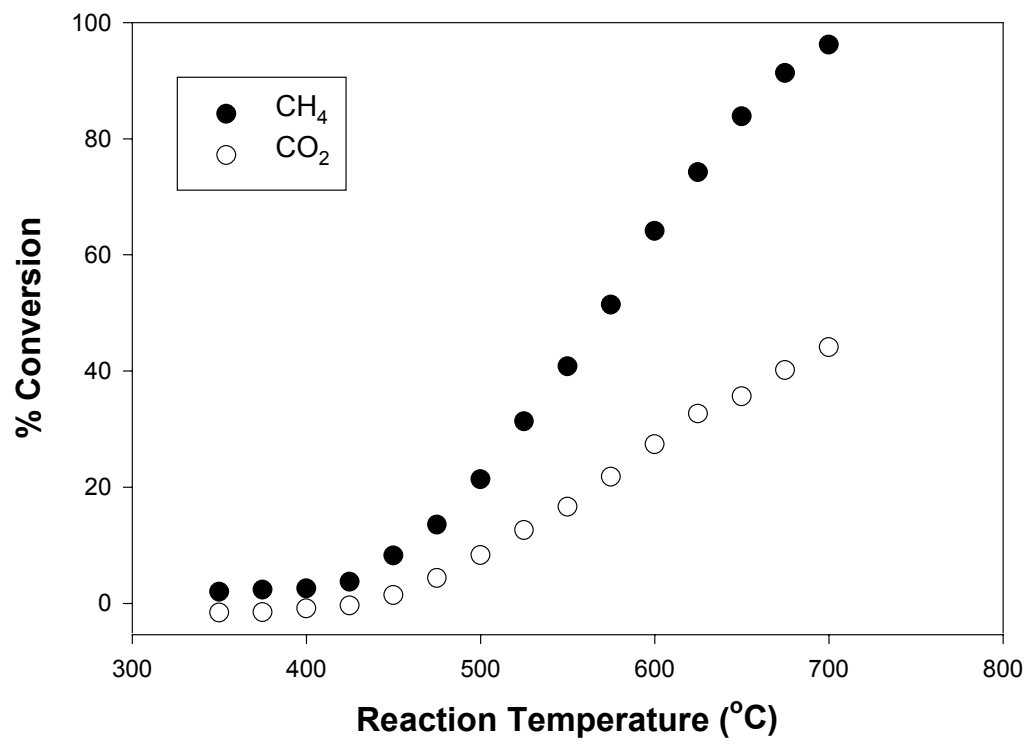

Figure 4.4 Effect of reaction temperatures on the activity over $\mathrm{Ni} / \mathrm{Al}_{2} \mathrm{O}_{3}$ catalyst. (Particle size 90-125 $\mu \mathrm{m}, \mathrm{CH}_{4} / \mathrm{CO}_{2} / \mathrm{Ar}=1 / 3.7 / 4.9$, total feed rate: $170 \mathrm{scc} / \mathrm{min}$ ) 
size range of $300-600 \mu \mathrm{m}$, the $\mathrm{CH}_{4}$ and $\mathrm{CO}_{2}$ conversions at $700{ }^{\circ} \mathrm{C}$ are $76 \%$ and $36 \%$, respectively. This is probably due to the intra-particular diffusion resistance in larger particles.

\section{Activation energy}

The dependence of reaction rates on the reaction temperature was measured at 450-525 ${ }^{\circ} \mathrm{C}$. The details of these rate calculations are given in Appendix D. The rates are calculated for a differential reactor setup with typical conversions less than $10 \%$. The rates of production of $\mathrm{H}_{2}, \mathrm{CO}$ and $\mathrm{H}_{2} \mathrm{O}$ as well as the rate of consumption of $\mathrm{CH}_{4}$ and $\mathrm{CO}_{2}$ are obtained as a function of reaction temperature. It is observed that, for the $\mathrm{Ni} / \mathrm{Al}_{2} \mathrm{O}_{3}$ catalyst, the $\mathrm{CO}$ production rate is greater than that of $\mathrm{H}_{2}$, but is comparable to the $\mathrm{H}_{2} \mathrm{O}$ production rate. However, the $\mathrm{CH}_{4}$ consumption rate is less than that of $\mathrm{CO}_{2}$, despite the $\mathrm{CH}_{4}$ conversion being greater than that of $\mathrm{CO}_{2}$. This is because $\mathrm{CH}_{4}$ is the limiting reactant and the reactants are not fed in a 1:1 ratio.

The Arrhenius plots of the rates of production or consumption of the species for varying reaction temperatures are given in Figure 4.5. The values of the activation energies, $E_{a}$, of different reaction species are tabulated in Table 4.1 below. These activation energies are found for initial catalytic activity with small reactant conversions at lower temperatures $\left(450-525{ }^{\circ} \mathrm{C}\right)$. Therefore, these values represent the low reaction rate regime, where the overall reaction is more temperature sensitive as compared to the existing diffusion limitations. The conversions and the rates increase with increasing temperatures. However, at higher temperatures, the diffusion limitations become predominant as compared to the temperature dependent kinetic limitation in the overall 


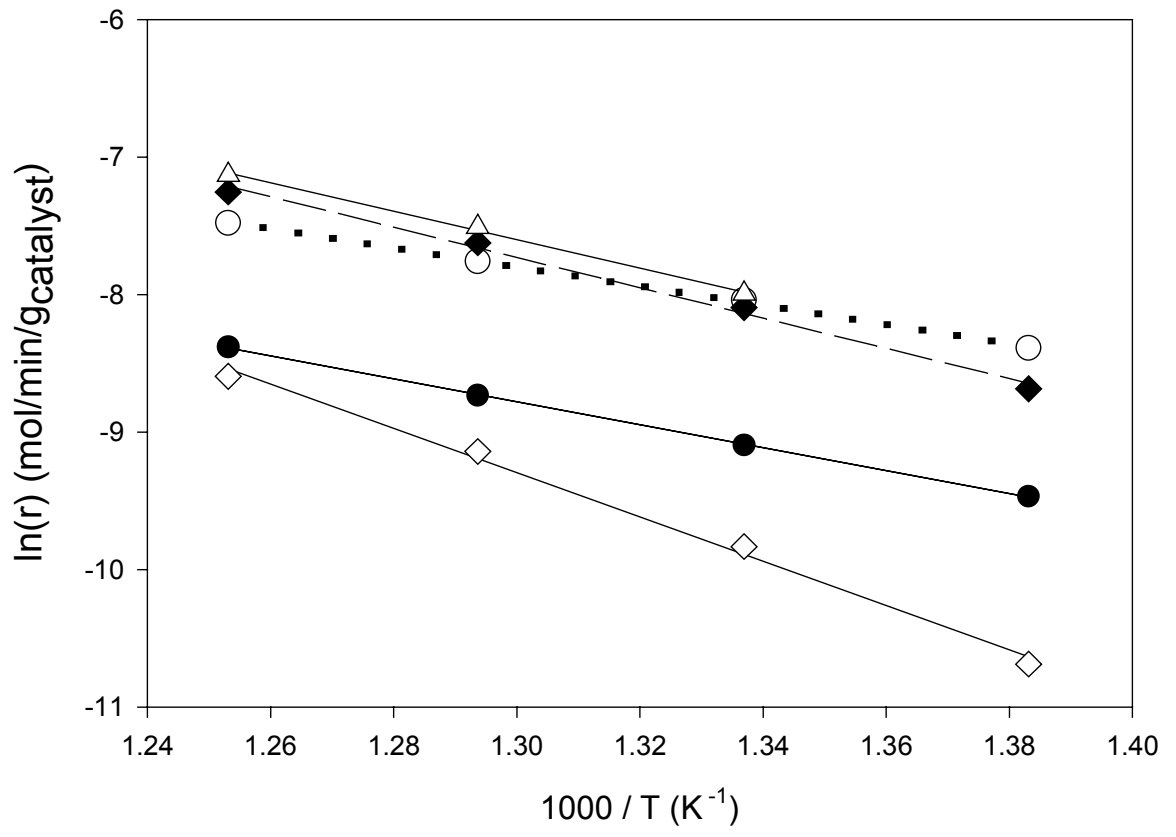

Figure 4.5 Arrhenius plots for initial $\mathrm{Ni} / \mathrm{Al2O} 3$ activity for $\mathrm{CH}_{4} / \mathrm{CO}_{2}$ reforming. (•) $\mathrm{CH}_{4}$ consumption; (O) $\mathrm{CO}_{2}$ consumption; ( $\left.\bullet\right) \mathrm{CO}$ production; ( $>$ ) $\mathrm{H}_{2}$ production; ( $\Delta$ ) $\mathrm{H}_{2} \mathrm{O}$ production. (Particle size 300-600 $\mu \mathrm{m}, \mathrm{CH} 4 / \mathrm{CO} / \mathrm{Ar}=1 / 3.7 /$ 4.9, total feed rate: $170 \mathrm{scc} / \mathrm{min})$.

Table 4.1. Activation energies for the $\mathrm{CO}_{2}$ reforming of $\mathrm{CH}_{4}$ over $\mathrm{Ni} / \mathrm{Al}_{2} \mathrm{O}_{3}$ catalyst

\begin{tabular}{|c|c|}
\hline $\begin{array}{c}\text { Reaction } \\
\text { Species }\end{array}$ & $\mathrm{E}_{\mathrm{a}}(\mathrm{kcal} / \mathrm{mol})$ \\
\hline $\mathrm{CH}_{4}$ & 16.6 \\
\hline $\mathrm{CO}_{2}$ & 13.81 \\
\hline $\mathrm{H}_{2}$ & 32.03 \\
\hline $\mathrm{CO}$ & 21.92 \\
\hline $\mathrm{H}_{2} \mathrm{O}$ & 20.53 \\
\hline
\end{tabular}


reaction. Hence, the overall reaction is diffusion as well as rate limited. Consequently, the activation energy is found to decrease at higher temperatures. Kroll et al. (1998) have reported that the activation energy decreases for increasing reactant conversions. Table 4.2 compares the values of $\mathrm{E}_{\mathrm{a}}$ obtained with those found in literature for various supported $\mathrm{Ni}$ catalysts. The $\mathrm{E}_{\mathrm{a}}$ values for products $\mathrm{H}_{2}, \mathrm{CO}$, and $\mathrm{H}_{2} \mathrm{O}$ reported in the literature are very much similar to those obtained in this investigation. However, the $E_{a}$ for the reactants varied in a greater range. This wider range of comparison may be attributed to the inaccuracy in measuring reactant consumptions, as well as the varying catalyst and reaction conditions. 
Table 4.2. Activation energies for the $\mathrm{CO}_{2}$ reforming of $\mathrm{CH}_{4}$ over supported Ni catalysts.

\begin{tabular}{|c|c|c|c|c|c|c|}
\hline \multirow{2}{*}{ Catalyst } & \multicolumn{5}{|c|}{$\mathrm{E}_{\mathrm{a}}(\mathrm{kcal} / \mathrm{mol})$} & \multirow[t]{2}{*}{ Reference } \\
\hline & $\mathrm{CH}_{4}$ & $\mathrm{CO}_{2}$ & $\mathbf{H}_{2}$ & $\mathbf{C O}$ & $\mathrm{H}_{2} \mathrm{O}$ & \\
\hline $\mathrm{Ni} / \alpha-\mathrm{Al}_{2} \mathrm{O}_{3}$ & 16.6 & 13.8 & 32.0 & 21.9 & 20.5 & current work \\
\hline \multirow{4}{*}{$\mathrm{Ni} / \mathrm{Al}_{2} \mathrm{O}_{3}$} & & & & 17 & & Zhang and Verykios (1994) \\
\hline & 10 & 8 & & 14 & & Seshan et al. (1994) \\
\hline & & & & 20 & & Osaki et al. (1995) \\
\hline & $14 \pm 4$ & & & & & Takano et al. (1994) \\
\hline $\mathrm{Ni} / \gamma-\mathrm{Al}_{2} \mathrm{O}_{3}$ & $12.2 \pm 2$ & $13.4 \pm 1.6$ & --- & $19.2 \pm 1.2$ & --- & Wang and Lu (2000) \\
\hline $\mathrm{Ni} / \mathrm{CeO}_{2}-\mathrm{Al}_{2} \mathrm{O}_{3}$ & $12.1 \pm 1.3$ & $18.4 \pm 2$ & --- & $20.8 \pm 2$ & --- & Wang and $\mathrm{Lu}(2000)$ \\
\hline $\mathrm{Ni} / \mathrm{CaO}-\mathrm{Al}_{2} \mathrm{O}_{3}$ & 19 & & & & & Horuichi et al. (1996) \\
\hline \multirow{3}{*}{$\mathrm{Ni} / \mathrm{SiO}_{2}$} & 23 & 19 & 27 & $20 \pm 3$ & 18 & Bradford and Vannice (1996) \\
\hline & 13 & & & & & Osaki et al. (1995) \\
\hline & 13 & & & & & Sakai et al. (1984) \\
\hline $\mathrm{Ni} / \mathrm{C}$ & 20 & 22 & 32 & 24 & 23 & Bradford and Vannice (1996) \\
\hline $\mathrm{Ni} / \mathrm{ZrO}_{2}$ & 14 & 10 & & 12 & & Seshan et al. (1994) \\
\hline $\mathrm{Ni} / \mathrm{MgO}$ & 22 & 21 & 35 & 21 & 18 & Bradford and Vannice (1996) \\
\hline $\mathrm{Ni} / \mathrm{TiO}_{2}$ & 26 & 21 & 32 & 23 & 22 & Bradford and Vannice (1996) \\
\hline
\end{tabular}




\subsection{Zirconia Supported Platinum Catalyst}

\subsubsection{Materials and Methodology}

The $\mathrm{Pt} / \mathrm{ZrO}{ }_{2}$ catalyst was prepared in-house. Zirconium oxide $\left(\mathrm{ZrO}_{2}\right)$ powder, obtained from Sigma-Aldrich, was first calcined at $852^{\circ} \mathrm{C}$ for over 18 hours in flowing air. The calcined support was isostatically pressed into pellets at 6000 bar for over 10 minutes. The pellets were crushed and sieved to give grains having diameter between 0.3 - $0.6 \mathrm{~mm}$. The grains were impregnated with $\mathrm{H}_{2} \mathrm{PtCl}_{6}$. $\mathrm{H}_{2} \mathrm{O}$ solution to yield $0.31 \%$ wt. Pt. The water was removed by heating the catalyst at $92{ }^{\circ} \mathrm{C}$ for 2 hours in a rotating evaporator followed by drying overnight at $92{ }^{\circ} \mathrm{C}$ in static air. The impregnated grains were calcined at $650^{\circ} \mathrm{C}$ for 15 hours. The Brunauer-Emmett-Teller (BET) surface area of the catalyst was determined to be $4-5 \mathrm{~m}^{2} / \mathrm{g}$.

Typically, $36 \mathrm{mg}$ of catalyst was used for testing the catalyst activity. The catalyst was pretreated in flowing $\mathrm{H}_{2}(12 \mathrm{scc} / \mathrm{min})$ at $150{ }^{\circ} \mathrm{C}$ for $30 \mathrm{~min}$. followed by pretreatment at $500{ }^{\circ} \mathrm{C}$ for 1 hour. Ar was then purged into the system for one hour. The feed ratio used was $\mathrm{CH}_{4}: \mathrm{CO}_{2}: \mathrm{Ar}=1: 1: 1.8$ with a total feed rate of $170 \mathrm{scc} / \mathrm{min}$. The total pressure in the system was maintained at one atm. The catalyst activity was tested at 400,450 and $500{ }^{\circ} \mathrm{C}$.

\subsubsection{Results and Discussion}

Results show very low conversions for the $\mathrm{Pt} / \mathrm{ZrO}_{2}$ catalyst. The total reactant conversion with $36 \mathrm{mg}$ of catalyst was less than $0.4 \%$ at $500{ }^{\circ} \mathrm{C}$. Pretreating at higher temperatures $\left(\mathrm{ca} 850{ }^{\circ} \mathrm{C}\right)$ with $\mathrm{H}_{2}$ did not result in any significant improvement in the 
conversion. Table 4.3 gives details of the various experiments performed and the conversions. Here the carbon formation is neglected, as the conversions are very low and the operating temperatures do not favor coke deposition as given by thermodynamics.

Table 4.3. Experimental details for the $\mathrm{CO}_{2}$ reforming of $\mathrm{CH}_{4}$ over $\mathrm{Pt} / \mathrm{ZrO}_{2}$ catalyst

\begin{tabular}{|c|c|c|}
\hline Reaction Conditions & $\mathrm{T}^{0} \mathrm{C}$ & \% Conversion \\
\hline \multirow{3}{*}{$\begin{array}{l}\text { 1) amt. of catalyst }=32.7 \mathrm{mg} \text {. } \\
\text { Reduced at } 500{ }^{\circ} \mathrm{C}, 12 \mathrm{cc} / \mathrm{min} \mathrm{H}_{2} \\
\mathrm{CH}_{4} / \mathrm{CO}_{2} / \mathrm{Ar}=1 / 1 / 1.18\end{array}$} & 450 & 0.19 \\
\hline & 500 & 0.28 \\
\hline & 550 & 0.39 \\
\hline \multirow{3}{*}{$\begin{array}{l}\text { 2) amt. of catalyst }=300 \mathrm{mg} \\
\text { Reduced at } 500{ }^{\circ} \mathrm{C}, 12 \mathrm{cc} / \mathrm{min} \mathrm{H}_{2} \\
\mathrm{CH}_{4} / \mathrm{CO}_{2} / \mathrm{Ar}=1 / 3.7 / 4.9\end{array}$} & 450 & 0.14 \\
\hline & 500 & 0.17 \\
\hline & 550 & 0.21 \\
\hline \multirow{3}{*}{$\begin{array}{l}\text { 2) amt. of catalyst }=300 \mathrm{mg} \\
\text { Reduced at } 850{ }^{\circ} \mathrm{C}, 77 \mathrm{cc} / \mathrm{min} \mathrm{H}_{2} \\
\mathrm{CH}_{4} / \mathrm{CO}_{2} / \mathrm{Ar}=1 / 3.7 / 4.9\end{array}$} & 400 & 0 \\
\hline & 500 & 0.07 \\
\hline & 600 & 0.26 \\
\hline
\end{tabular}

Later, it was found that the catalyst was deactivating within 2 hours into the reaction.

Figure 4.6 shows the decrease in the area counts of the product peaks for the time spent by the catalyst on stream. Thus, this prepared catalyst was found to be very unstable. This could be due to the unstable zirconia support. The possible explanation for this could be due to the calcination carried out at $850{ }^{\circ} \mathrm{C}$. However, no further study was made on this catalyst. 


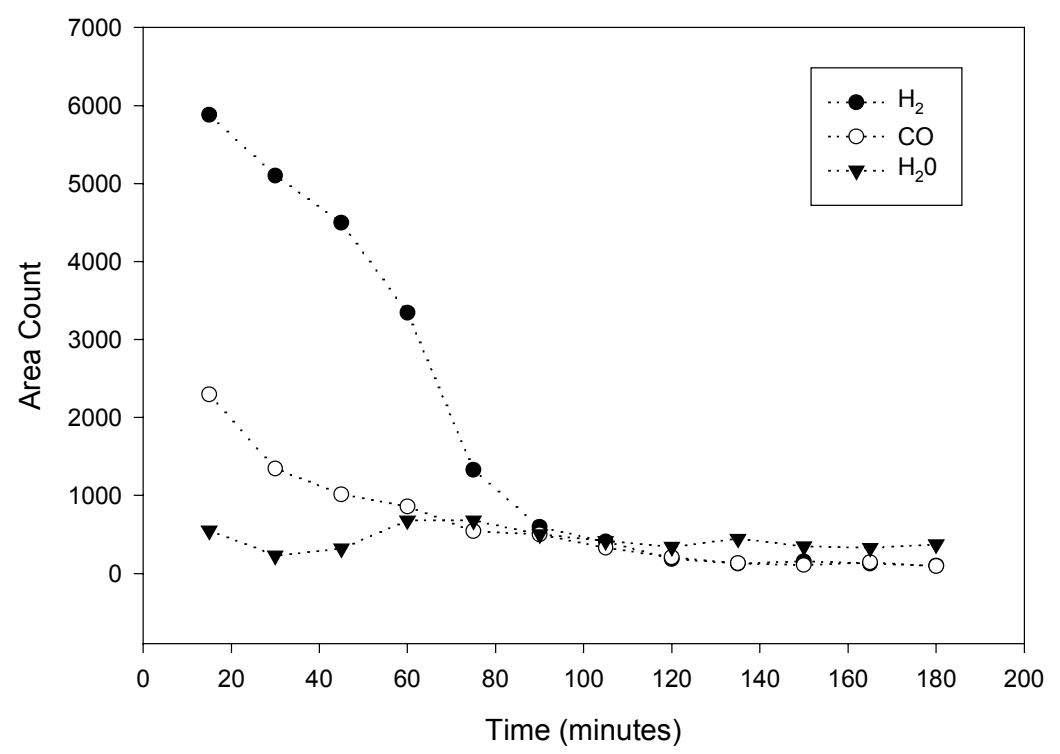

Figure 4.6 Deactivation of the $\mathrm{Pt} / \mathrm{ZrO}_{2}$ catalyst for $\mathrm{CH}_{4} / \mathrm{CO}_{2}$ reforming.

\subsection{Summary}

The activity of the commercial $\mathrm{Ni} / \mathrm{Al}_{2} \mathrm{O}_{3}$ catalyst for methane reforming with carbon dioxide was studied for a feed ratio of $\mathrm{CH}_{4}: \mathrm{CO}_{2}=1: 3.7$, and for two different particle sizes. The reaction temperature cycles seem to stabilize the catalyst activity. The reactant conversions for the decreasing temperature cycles are higher than those obtained for the initial increasing temperature cycles. The apparent activation energies for the reaction species were obtained for $450-525^{\circ} \mathrm{C}$ temperature ranges. These values are found to be consistent with reported values in the literature. The $\mathrm{Pt} / \mathrm{ZrO}_{2}$ catalyst was found to be to be deactivating within 2 hours. No further study was made on this catalyst. 


\section{CHAPTER 5}

\section{TUNGSTEN CARBIDE CATALYST}

\subsection{Introduction}

There has been considerable work carried out in methane dry reforming with carbon dioxide in the last few decades, as seen in Chapter 2. However, most of these efforts were concentrated on supported nickel and noble metal catalysts. The coking problems associated with nickel catalysts and the high costs of noble metal catalysts have shifted the focus of this research towards the less-expensive metal carbides. There have been reports of molybdenum and tungsten carbide catalysts being active for the methane dry reforming reaction without any significant deactivation at high pressures and temperatures (Claridge et al., 1998; Brungs et al., 2000; Oshikawa et al., 2000; Tsuji et al., 2000; Shamsi and Lyons, 2000). These groups have primarily focused on preparation and testing of the catalytic activity of molybdenum and tungsten carbide catalysts, as well as characterization and some mechanistic studies. However, there have been no significant kinetic studies reported for these metal carbide catalysts in methane dry reforming with carbon dioxide.

The purpose of this study is to investigate the performance of cobalt tungsten carbide $\left[\mathrm{Co}_{6} \mathrm{~W}_{6} \mathrm{C}\right]$ for the dry reforming of methane to produce synthesis gas. This carbide is primarily used as a precursor of material for cutting tools. The primary objective here was to test the catalytic activity and stability of this material. Later on, the focus shifted towards the kinetic studies and reaction modeling by understanding the 
behavior of the reaction rates with varying partial pressures of methane and carbon dioxide.

\subsection{Materials and Initial Methodology}

The unsupported cobalt tungsten carbide material $\left[\mathrm{Co}_{6} \mathrm{~W}_{6} \mathrm{C}\right]$ to be used as a catalyst for methane dry reforming was obtained from Nanodyne Inc. The details of the preparation procedure can be obtained from Kugler et al. (1992). The unsupported material has a BET surface area of about $5 \mathrm{~m}^{2} / \mathrm{g}$. The material was then crushed and sieved into particles of $90-125 \mu \mathrm{m}(120-170 \mathrm{mesh})$ and $<38 \mu \mathrm{m}$ (400 mesh) in size. Typically, $300 \mathrm{mg}$ of the catalyst was tested in each run. The pretreatment was initially carried out by flowing $\mathrm{H}_{2}(62 \mathrm{scc} / \mathrm{min})$ at $400{ }^{\circ} \mathrm{C}$ for 1 hour. The system was later flushed with $\operatorname{Ar}(190 \mathrm{scc} / \mathrm{min})$ at $400{ }^{\circ} \mathrm{C}$ for 1 hour. The entire pretreatment was performed in-situ at atmospheric pressure.

Initially, the feed mixture was introduced with a feed ratio of $\mathrm{CH}_{4}: \mathrm{CO}_{2}=1: 1$. Ar was used as an inert, and He was the internal standard. The weight hourly space velocity (WHSV) of the feed mixture was varied from 3000 to $10,500 \mathrm{scc} / \mathrm{hr} / \mathrm{g}_{\text {catalyst. }}$ The partial pressure of each of the reactant was varied from 0.5 to about $4 \mathrm{~atm}$. However, the total pressure of the reactor was maintained between $3-5 \mathrm{~atm}$.

Both small $(<38 \mu \mathrm{m})$ and large $(90-125 \mu \mathrm{m})$ particle size catalysts were tested at various reaction temperatures. The reaction temperature was progressively raised in increments of $50{ }^{\circ} \mathrm{C}$, starting from an initial temperature of $600{ }^{\circ} \mathrm{C}$ up to a final temperature of $850{ }^{\circ} \mathrm{C}$. The temperature was maintained constant at $850{ }^{\circ} \mathrm{C}$ for 2 hours in the feed mixture. The reaction temperature was then progressively lowered in decrements 
of $50{ }^{\circ} \mathrm{C}$, until the temperature of $600{ }^{\circ} \mathrm{C}$ was once again obtained. The reaction temperature was held constant for 1 hour after every $50{ }^{\circ} \mathrm{C}$ increment or decrement and the product samples from the downstream of the reactor were analyzed on-line at $15 \mathrm{~min}$. intervals.

\subsection{Results and Discussion}

\subsubsection{Preliminary Investigation with Unstabilized Catalyst}

Effect of reaction temperature and inert gas

The values of $\mathrm{CH}_{4}$ conversions for the increasing and decreasing temperature cycles with $90-125 \mu \mathrm{m}$ particle sizes are as shown in Figure 5.1. The feed ratio of $\mathrm{CH}_{4} / \mathrm{CO}_{2}$ was maintained close to unity. The total reactant WHSV was maintained at $9070 \mathrm{scc} / \mathrm{hr} / \mathrm{g}_{\text {catalyst }}$. The total reaction pressure was varied from $3 \mathrm{~atm}$ to $5 \mathrm{~atm}$. The partial pressure of each the reactants was maintained at $1 \mathrm{~atm}$ for all the experiments; however, the partial pressure of the inert (Ar) was changed from 1 atm to $3 \mathrm{~atm}$. This could help us deduce the inhibition effects of the inert on the reactant conversions.

From Figure 5.1, during the first increasing temperature cycle, the $\mathrm{CH}_{4}$ conversion increases with temperature, reaching its highest value of $23 \%$ at $850{ }^{\circ} \mathrm{C}$. The decreasing temperature cycle shows an identical trend with the same values for $\mathrm{CH}_{4}$ conversions. This cycle was performed with a total pressure of $3 \mathrm{~atm}$. In the subsequent cycle, the total pressure was increased to 5 atm. However, as observed in Figure 5.1, the $\mathrm{CH}_{4}$ conversions obtained are identical to the previous cycle with $\mathrm{P}_{\mathrm{T}}=3 \mathrm{~atm}$. Therefore, we can infer that the inert, Ar, does not affect the catalytic activity. However, Silva et al. 
(1979) report of inerts like $\mathrm{He}$, Ar decreasing the rate of $\mathrm{CO}$ oxidation over $\mathrm{V}_{2} \mathrm{O}_{5}$ catalyst with increasing inert partial pressure at constant partial pressure of the reactants. Hence, they conclude that this represents the inhibitive effect of the inerts on the catalytic activity. However, these observations could be due to the result of diffusional limitations caused by increase in the inert concentrations in the catalyst pores.

Figure 5.2 compares the $\mathrm{CH}_{4}$ conversions for the first and third temperature cycle. The reaction conditions are kept identical for these temperature cycles. This gives a measure of the catalyst stability after 24 hours, as each temperature cycle takes about 12 hours. It is observed that the catalyst maintains its activity, as the results are reproducible.

Figures 5.3 and 5.4 give the $\mathrm{CO}_{2}$ conversions for the same set of experiments discussed above, and are analogous to Figures 5.1 and 5.2 for $\mathrm{CH}_{4}$. The maximum $\mathrm{CO}_{2}$ conversion obtained at $850{ }^{\circ} \mathrm{C}$ is $44 \%$. Although we get reproducible $\mathrm{CH}_{4}$ conversions, the $\mathrm{CO}_{2}$ conversions are not exactly reproducible. This is because the calculations are based on the internal standard (He). Helium is present in the same cylinder source as $\mathrm{CH}_{4}$. It was also observed that small fluctuations in the room temperature affect the calibration and the flow of the gases through the mass flow controllers. However, as the $\mathrm{CH}_{4}$ and $\mathrm{He}$ come from the same source, the discrepancies cancel each other. On the other hand, since $\mathrm{CO}_{2}$ comes from a different source, $\mathrm{CO}_{2}$ is affected by these fluctuations. Hence, we do not get reproducible conversions for $\mathrm{CO}_{2}$.

Further experiments were performed to confirm this hypothesis. For this purpose, a gas mixture consisting of the reactants $\left(\mathrm{CH}_{4}\right.$ and $\left.\mathrm{CO}_{2}\right)$, the internal standard $(\mathrm{He})$ and the inert (Ar) was used for further testing. The particle size used was $<38 \mu \mathrm{m}$ and the 


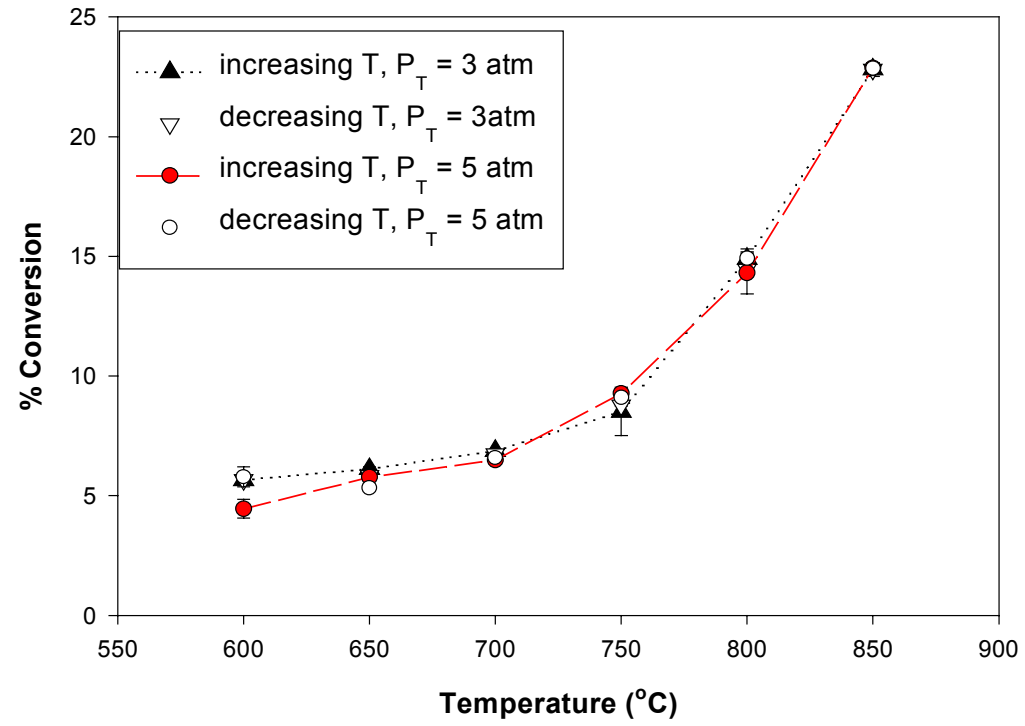

Figure 5.1 Effect of increasing and decreasing reaction temperature cycles on $\mathrm{CH}_{4}$ conversion over $\mathrm{Co}_{6} \mathrm{~W}_{6} \mathrm{C}$ catalyst at different total pressures. (Particle size 90-125 $\mu \mathrm{m}, \mathrm{CH}_{4} / \mathrm{CO}_{2} / \mathrm{Ar}=1 / 1 /(\mathrm{x}-2)$, where $\mathrm{x}=\mathrm{P}_{\text {total }}$ in atm. $)$

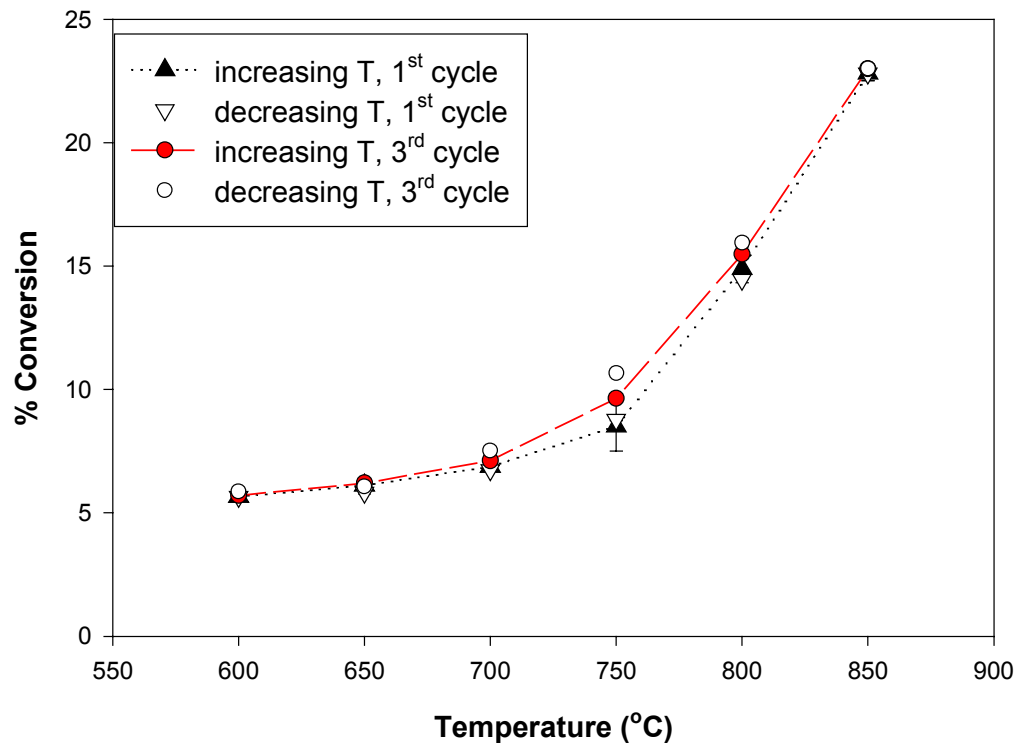

Figure 5.2 Effect of the number of reaction temperature cycles on $\mathrm{CH}_{4}$ conversion over $\mathrm{Co}_{6} \mathrm{~W}_{6} \mathrm{C}$ catalyst. (Particle size 90-125 $\mu \mathrm{m}, \mathrm{CH}_{4} / \mathrm{CO}_{2} / \mathrm{Ar}=1 / 1 / 1, \mathrm{P}_{\text {total }}=3 \mathrm{~atm}$.) 


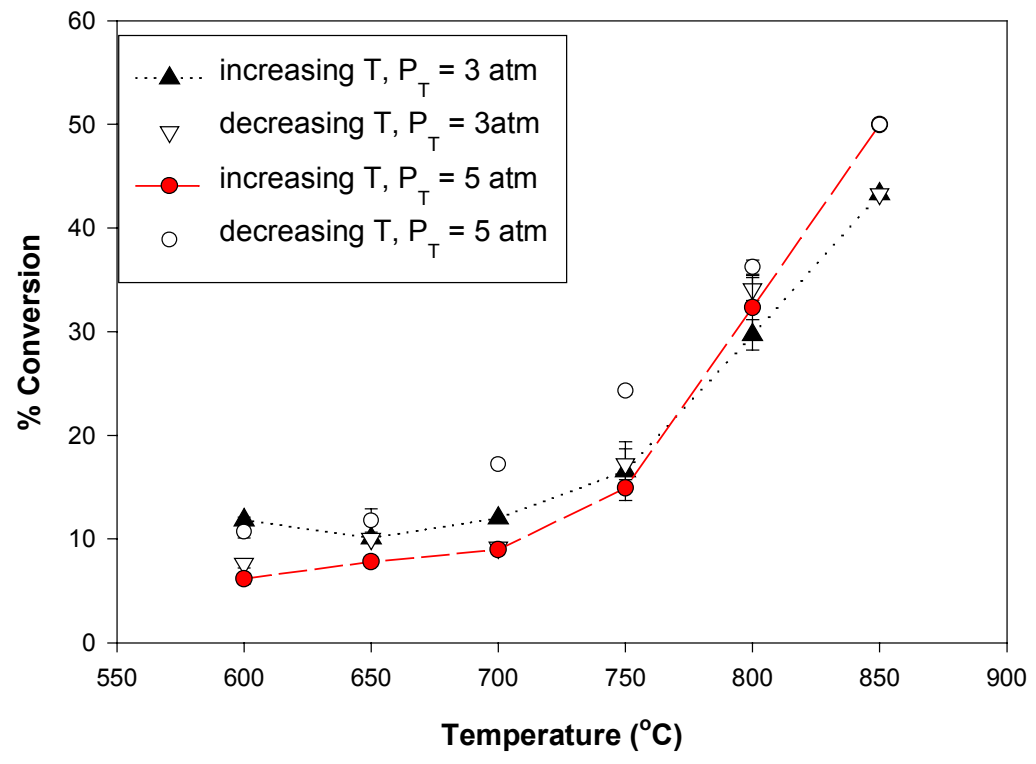

Figure 5.3 Effect of increasing and decreasing reaction temperature cycles on $\mathrm{CO}_{2}$ conversion over $\mathrm{Co}_{6} \mathrm{~W}_{6} \mathrm{C}$ catalyst at different total pressures. (Particle size 90-125 $\mu \mathrm{m}, \mathrm{CH}_{4} / \mathrm{CO}_{2} / \mathrm{Ar}=1 / 1 /(\mathrm{x}-2)$, where $\mathrm{x}=\mathrm{P}_{\text {total }}$ in atm.)

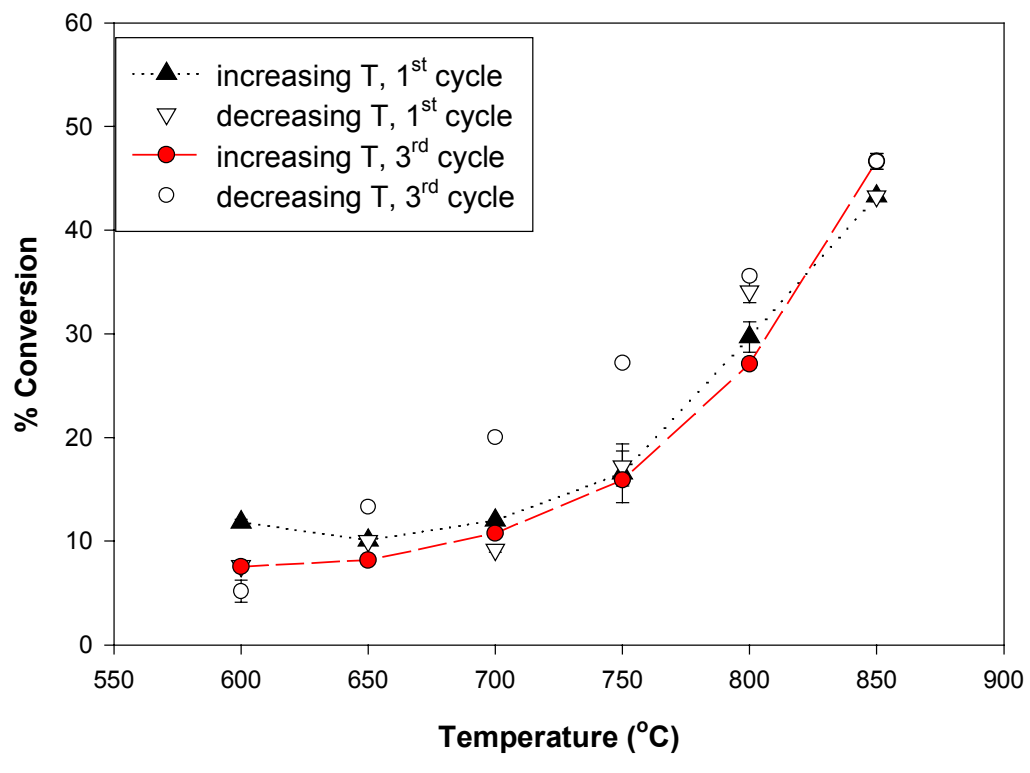

Figure 5.4 Effect of the number of reaction temperature cycles on $\mathrm{CO}_{2}$ conversion over $\mathrm{Co}_{6} \mathrm{~W}_{6} \mathrm{C}$ catalyst. (Particle size 90-125 $\mu \mathrm{m}, \mathrm{CH}_{4} / \mathrm{CO}_{2} / \mathrm{Ar}=1 / 1 / 1, \mathrm{P}_{\text {total }}=3 \mathrm{~atm}$.) 
ratio of the feed mixture was fixed at $\mathrm{CH}_{4} / \mathrm{CO}_{2} / \mathrm{Ar}=1 / 1 / 1.4$. Figures 5.5 and 5.6 give the effect of the increasing and decreasing temperature cycles on the $\mathrm{CH}_{4}$ and $\mathrm{CO}_{2}$ conversions respectively under these conditions. The maximum $\mathrm{CH}_{4}$ and $\mathrm{CO}_{2}$ conversions obtained are $44 \%$ and $62 \%$ respectively. Now the results for both the $\mathrm{CH}_{4}$ and $\mathrm{CO}_{2}$ conversions are reproducible for increasing, decreasing and increasing $\left(2^{\text {nd }}\right.$ cycle) cycles performed sequentially. Hence, it is reasonable to believe that the error in the $\mathrm{CO}_{2}$ conversions in the previous set of experiments is due to the different sources of $\mathrm{CO}_{2}$ and $\mathrm{He}$. However, as a precautionary measure, the room temperature was maintained nearly constant, for the remainder of the experiments, by frequently adjusting the thermostat. Besides, the mass flow controllers were enclosed in an insulated Styrofoam container to minimize the effects of room temperature on the calibration process (section 3.2.3).

Figures 5.2 and 5.5 give the effect of reaction temperatures on the $\mathrm{CH}_{4}$ conversions for different catalyst particle sizes. The maximum $\mathrm{CH}_{4}$ conversion obtained at $850{ }^{\circ} \mathrm{C}$ for $90-125 \mu \mathrm{m}$ particle size is $23 \%$ (Figure 5.2), while that for the smaller particle size $(<38 \mu \mathrm{m})$ is $44 \%$ (Figure 5.5 ). Similarly, Figures 5.4 and 5.6 give the effect of reaction temperatures on the $\mathrm{CO}_{2}$ conversions for different catalyst particle sizes. The maximum $\mathrm{CO}_{2}$ conversion obtained at $850{ }^{\circ} \mathrm{C}$ for $90-125 \mu \mathrm{m}$ particle size is $44 \%$ (Figure 5.4), while that for the smaller particle size $(<38 \mu \mathrm{m})$ is $62 \%$ (Figure 5.6). Thus, we see an increase in the conversion with decreasing particle sizes for the same reaction conditions. 


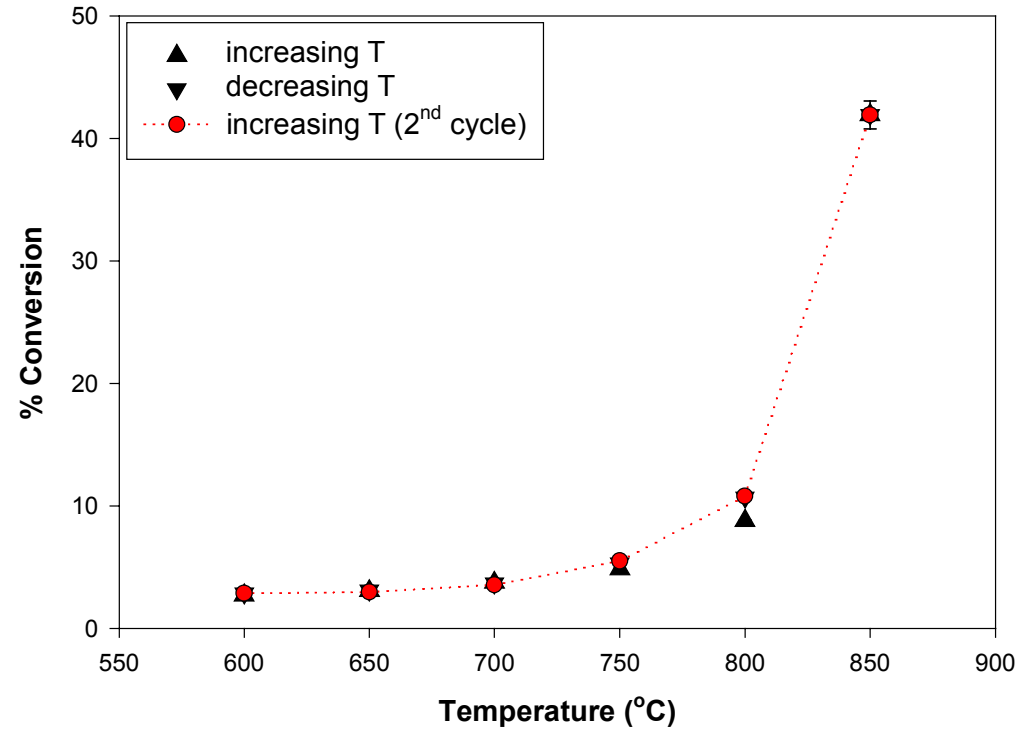

Figure 5.5 Effect of reaction temperature cycles on $\mathrm{CH}_{4}$ conversion over $\mathrm{Co}_{6} \mathrm{~W}_{6} \mathrm{C}$ catalyst. (All reactants and inerts are in the same cylinder. Particle size $<38 \mu \mathrm{m}$, $\mathrm{CH}_{4} / \mathrm{CO}_{2} / \mathrm{Ar}=1 / 1 / 1.4, \mathrm{P}_{\text {total }}=3.4 \mathrm{~atm}$.)

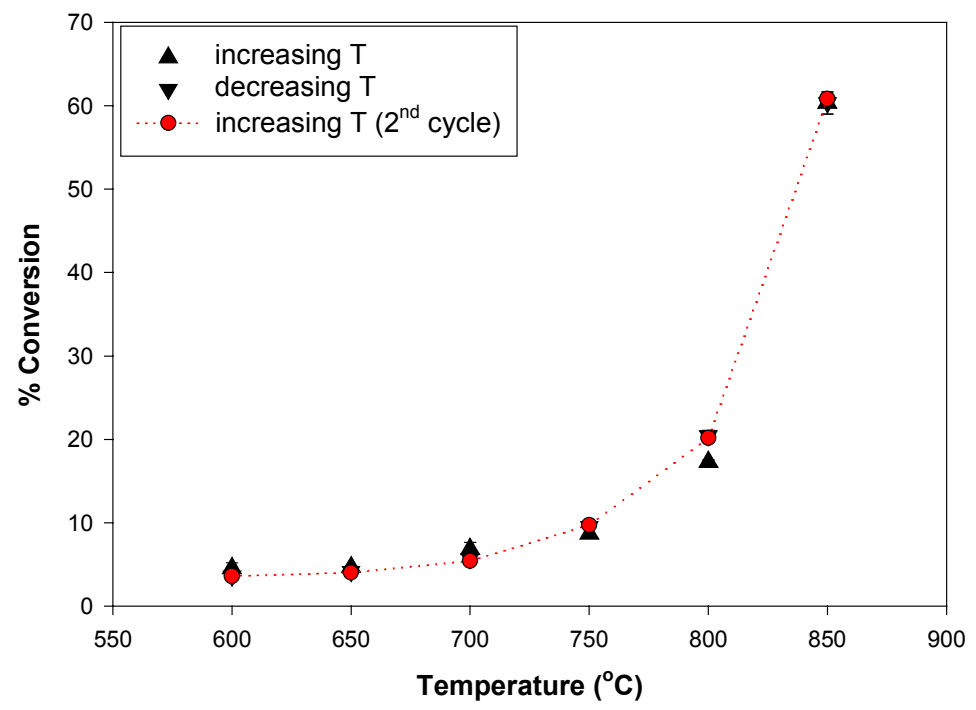

Figure 5.6 Effect of reaction temperature cycles on $\mathrm{CO}_{2}$ conversion over $\mathrm{Co}_{6} \mathrm{~W}_{6} \mathrm{C}$ catalyst. (All reactants and inerts are in the same cylinder. Particle size $<38 \mu \mathrm{m}$, $\mathrm{CH}_{4} / \mathrm{CO}_{2} / \mathrm{Ar}=1 / 1 / 1.4, \mathrm{P}_{\text {total }}=3.4 \mathrm{~atm}$.) 
Figures 5.7 and 5.8 shown below, give the effect of reaction temperature on the $\mathrm{H}_{2} / \mathrm{CO}$ ratio for different catalyst particle sizes. The feed ratio of $\mathrm{CH}_{4} / \mathrm{CO}_{2}$ was maintained close to unity. The total reactant WHSV was maintained at 9070 $\mathrm{scc} / \mathrm{hr} / \mathrm{g}_{\text {catalyst }}$. The $\mathrm{H}_{2} / \mathrm{CO}$ ratio increases with increasing temperature. However, smaller particles of catalyst give higher ratios than the larger particles. The maximum value for $\mathrm{H}_{2} / \mathrm{CO}$ ratio at $850{ }^{\circ} \mathrm{C}$ is 0.46 for larger particles and 0.79 for the smaller ones. The $\mathrm{H}_{2} / \mathrm{CO}$ ratio for the smaller particles rises considerably from 0.4 at $800{ }^{\circ} \mathrm{C}$ to 0.79 at 850 ${ }^{\circ} \mathrm{C}$ as seen in Figure 5.8. However, no such effect is seen for the larger particles where the values increase gradually.

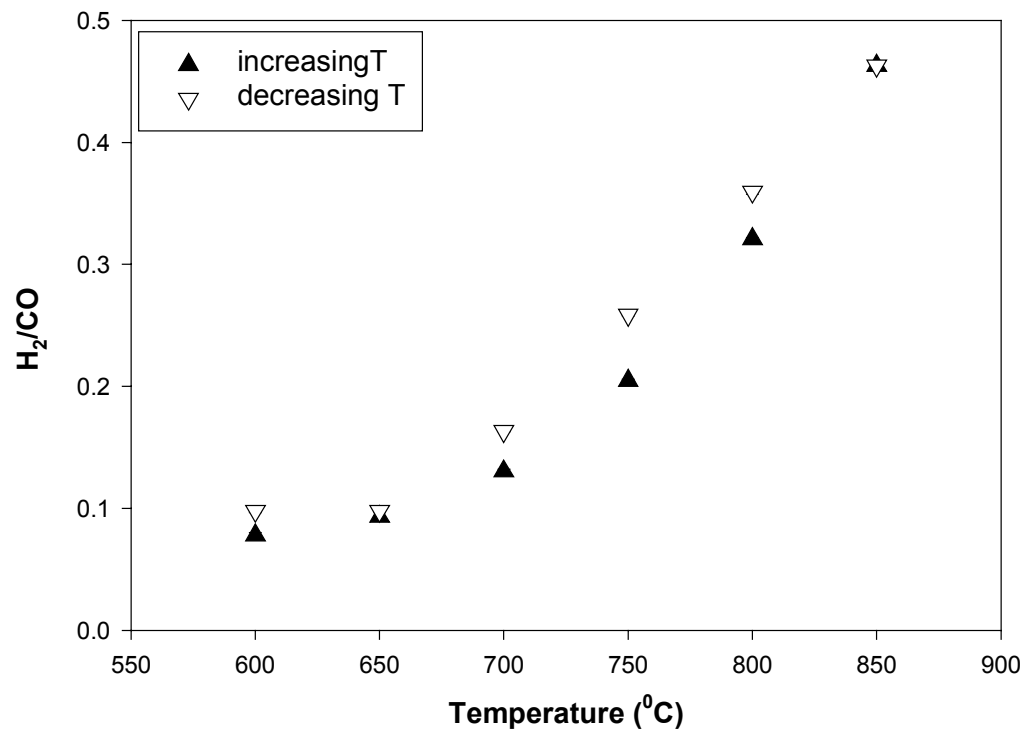

Figure 5.7 Effect of reaction temperatures on $\mathrm{H}_{2} / \mathrm{CO}$ ratio for $\mathrm{CO}_{2}$ reforming of $\mathrm{CH}_{4}$ with $\mathrm{Co}_{6} \mathrm{~W}_{6} \mathrm{C}$ catalyst. (Particle size 90-125 $\mu \mathrm{m}, \mathrm{CH}_{4} / \mathrm{CO}_{2} / \mathrm{Ar}=1 / 1 / 1, \mathrm{P}_{\text {total }}=3$ atm.) 


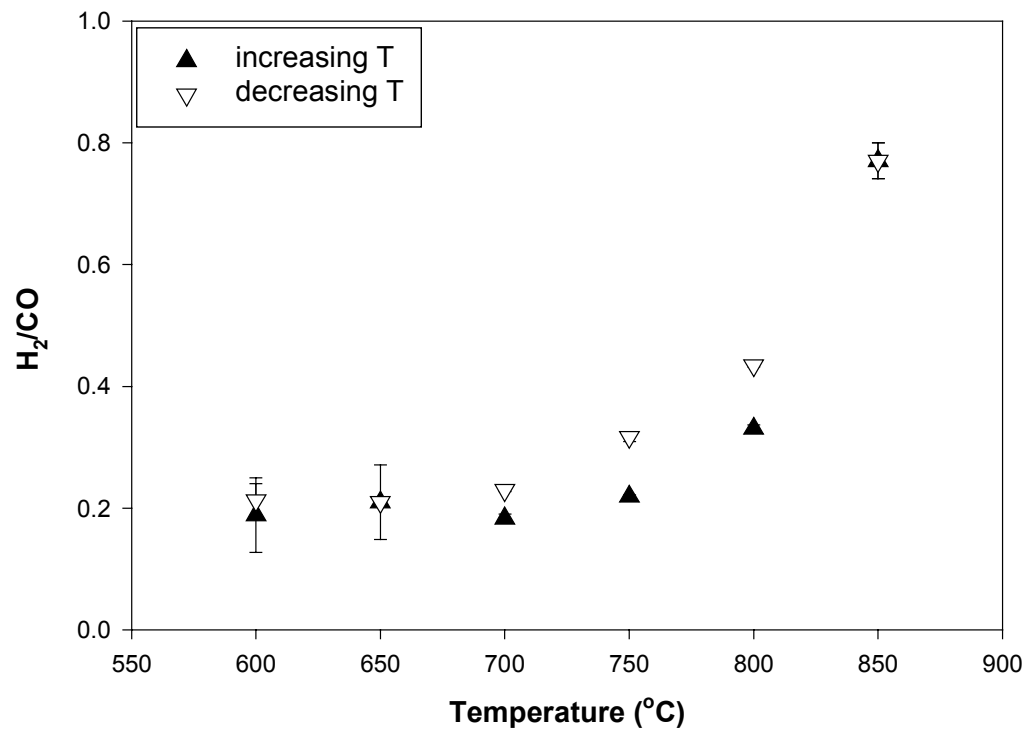

Figure 5.8 Effect of reaction temperatures on $\mathrm{H}_{2} / \mathrm{CO}$ ratio for $\mathrm{CO}_{2}$ reforming of $\mathrm{CH}_{4}$ with $\mathrm{Co}_{6} \mathrm{~W}_{6} \mathrm{C}$ catalyst. (Particle size $<38 \mu \mathrm{m}, \mathrm{CH}_{4} / \mathrm{CO}_{2} / \mathrm{Ar}=1 / 1 / 1.4, \mathrm{P}_{\text {total }}=3.4$ atm.)

\subsubsection{Activity of Blank Reactor}

The experiments described so far have been carried out for high conversions. Therefore, the small catalytic effect of the stainless-steel reactor was not considered. However, for the measurement of the kinetic data, it is required to operate in the lowconversion, differential mode. Hence, the catalytic effect of the reactor can not be neglected. For this reason, the reactor was passivated by lining it with silica. The silica lining on the stainless-steel reactor tubes was applied at Restek Corp.

Prior to testing of the catalyst, the silica-lined reactor was tested for initial catalytic activity. Catalyst was not used during this testing and the reactor was filled with quartz chips. The details of the reactor loading are as given in Section 3.2.1. The 
pretreatment was carried out in-situ by flowing $\mathrm{H}_{2}(62 \mathrm{scc} / \mathrm{min})$ at $400{ }^{\circ} \mathrm{C}$ for 1 hour. The system was then flushed with $\operatorname{Ar}(190 \mathrm{scc} / \mathrm{min})$ at $400{ }^{\circ} \mathrm{C}$ for 1 hour. The entire pretreatment was performed at atmospheric pressure and was identical to that for the catalyst testing. The feed was then introduced in the system and the feed ratio was maintained at $\mathrm{CH}_{4} / \mathrm{CO}_{2} / \mathrm{Ar}=1 / 1 / 3$. The total reactant flow was maintained at 1300 $\mathrm{scc} / \mathrm{hr}$. The reaction temperature was gradually raised from $400{ }^{\circ} \mathrm{C}$ to $850{ }^{\circ} \mathrm{C}$. The reaction conditions were maintained at $850{ }^{\circ} \mathrm{C}$ for 24 hours. The reaction temperatures were subsequently lowered in steps of $50{ }^{\circ} \mathrm{C}$ down to $700{ }^{\circ} \mathrm{C}$ and the conversions were noted. Since there was no evidence of any catalytic activity at $700{ }^{\circ} \mathrm{C}$, no data were collected for temperatures below $700{ }^{\circ} \mathrm{C}$. The details are as given in Figure 5.9.

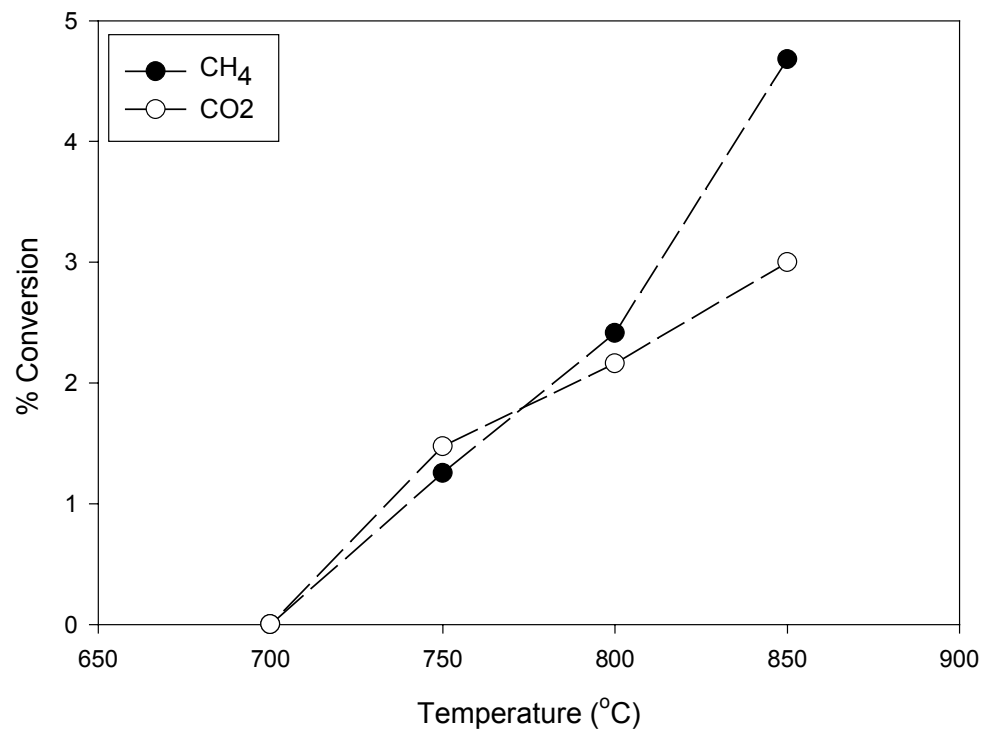

Figure 5.9 Effect of reaction temperatures on the activity of the silica lined blank reactor for $\mathrm{CO}_{2}$ reforming of $\mathrm{CH}_{4}\left(\mathrm{CH}_{4} / \mathrm{CO}_{2} / \mathrm{Ar}=1 / 1 / 3, \mathrm{P}_{\text {total }}=5 \mathrm{~atm}\right.$. $)$

The blank reactor shows the largest activity at $850{ }^{\circ} \mathrm{C}$, with $\mathrm{CH}_{4}$ and $\mathrm{CO}_{2}$ conversions of $4.7 \%$ and $3 \%$ respectively. The activity decreases with decreasing 
temperature, and the reactor shows no activity at and below $700{ }^{\circ} \mathrm{C}$. For the purpose of correction during the catalyst testing, it is essential to obtain the rates of formation of products or consumption of reactants. Hence, the rates of formation of the products, as well as the rates of consumption of the reactants, were obtained at every temperature and are as shown in Figure 5.10. These rates were then subtracted from the total catalystreactor system activity to give the net activity of the catalyst itself. The details of the calculations of the rates as well as the subtraction of the blank-reactor rates are given in Appendix E.

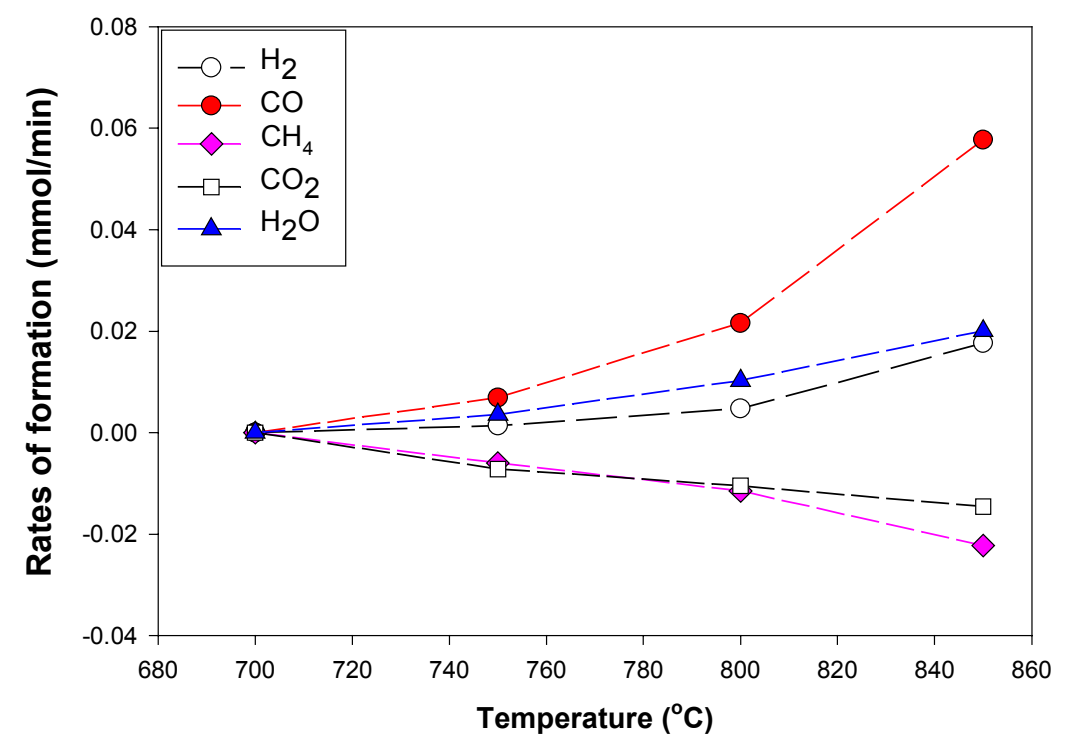

Figure 5.10 Effect of reaction temperatures on the rates of formation of different species in the silica lined blank reactor for the $\mathrm{CO}_{2}$ reforming of $\mathrm{CH}_{4}\left(\mathrm{CH}_{4} / \mathrm{CO}_{2} / \mathrm{Ar}\right.$ $=1 / 1 / 3, P_{\text {total }}=5$ atm.) 


\subsubsection{Testing of the Catalyst Activity}

\section{Stabilization of the Catalyst}

The unsupported cobalt tungsten carbide catalyst was tested for activity at various reaction temperatures at a constant feed ratio. The particle size of the catalyst used was less than $38 \mu \mathrm{m}$. The pretreatment was carried out in-situ by flowing $\mathrm{H}_{2}(62 \mathrm{scc} / \mathrm{min})$ at $400{ }^{\circ} \mathrm{C}$ for 1 hour. The system was then flushed with $\operatorname{Ar}(190 \mathrm{scc} / \mathrm{min})$ at $400{ }^{\circ} \mathrm{C}$ for 1 hour. The entire pretreatment was performed at atmospheric pressure. The feed mixture was then introduced in the system, with the feed ratio maintained at $\mathrm{CH}_{4} / \mathrm{CO}_{2} / \mathrm{Ar}=1 / 1 / 3$ and $\mathrm{P}_{\text {total }}=5 \mathrm{~atm}$. The reaction temperature was raised from $400{ }^{\circ} \mathrm{C}$ to $850{ }^{\circ} \mathrm{C}$ over 1.5 hours and was then maintained at $850{ }^{\circ} \mathrm{C}$ in the reactant mixture. The lifetime study of the catalyst at $850{ }^{\circ} \mathrm{C}$ (from $\mathrm{t}=0$ hours) is as shown in Figures 5.11 and 5.12.

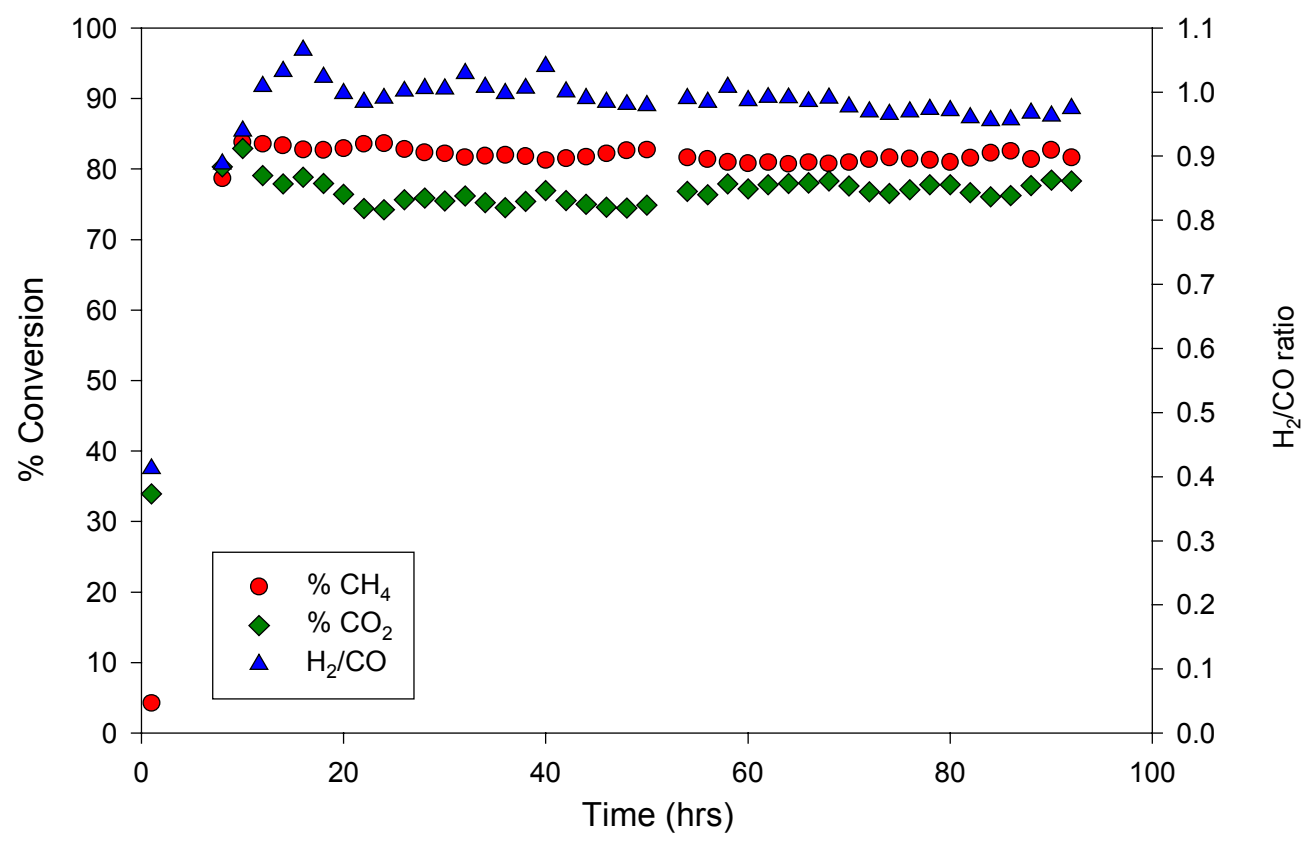

Figure 5.11 Conversions during the lifetime study of the $\mathrm{Co}_{6} \mathrm{~W}_{6} \mathrm{C}$ catalyst for the $\mathrm{CO}_{2}$ reforming of $\mathrm{CH}_{4}\left(\mathrm{~T}=850{ }^{\circ} \mathrm{C}\right.$, particle size $<38 \mu \mathrm{m}, \mathrm{CH}_{4} / \mathrm{CO}_{2} / \mathrm{Ar}=1 / 1 / 3, \mathrm{P}_{\text {total }}$ $=5 \mathrm{~atm}$. , reactant $\mathrm{WHSV}=4250 \mathrm{scc} / \mathrm{hr} / \mathrm{g}_{\text {catalyst }}$ ) 


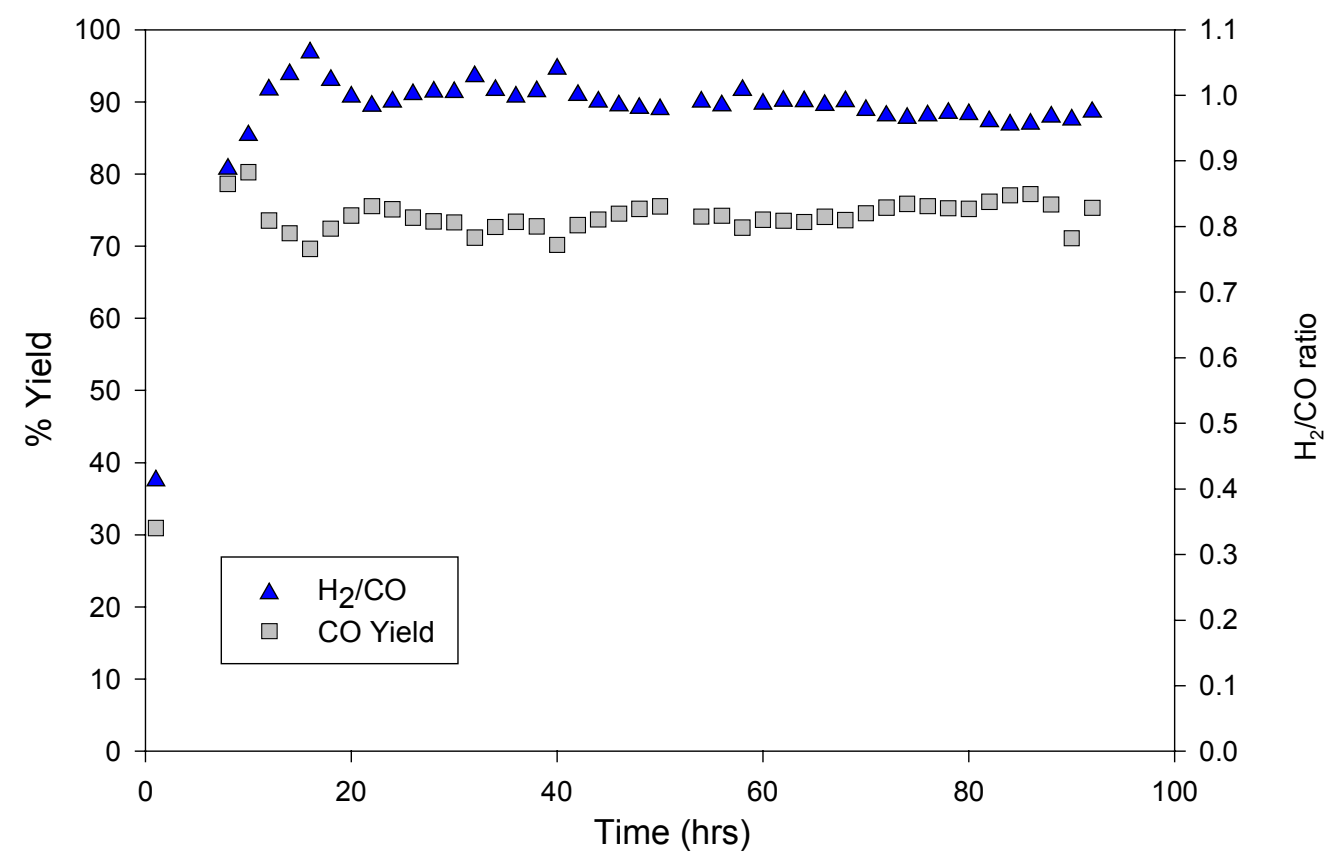

Figure 5.12 CO yields and product selectivity during the lifetime study of the $\mathrm{Co}_{6} \mathrm{~W}_{6} \mathrm{C}$ catalyst for the $\mathrm{CO}_{2}$ reforming of $\mathrm{CH}_{4}\left(\mathrm{~T}=850{ }^{\circ} \mathrm{C}\right.$, particle size $<38 \mu \mathrm{m}$, $\mathrm{CH}_{4} / \mathrm{CO}_{2} / \mathrm{Ar}=1 / 1 / 3, \mathrm{P}_{\text {total }}=5 \mathrm{~atm}$. , reactant $\left.\mathrm{WHSV}=4250 \mathrm{scc} / \mathrm{hr} / \mathrm{g}_{\text {catalyst}}\right)$

The $\mathrm{CH}_{4}$ and $\mathrm{CO}_{2}$ conversions increase steadily during the first 20 hours at $850{ }^{\circ} \mathrm{C}$ and then stabilize at $82 \%$ and $78 \%$ respectively, with a $\mathrm{H}_{2} / \mathrm{CO}$ ratio close to 1 . The $\mathrm{CO}$ yield was about $76 \%$. The details of the calculation of the $\mathrm{CO}$ yield are given in Appendix E (eqn. E.10, section E.2.2). The catalyst was found to be very stable at 850 ${ }^{0} \mathrm{C}$ for a period of over 90 hours.

\section{Effect of Reaction Temperature}

The catalyst was then tested at various temperatures as shown in Figure 5.13. This was a continuation of the lifetime study, and a fresh batch of catalyst was not used. The $\mathrm{CH}_{4}$ and $\mathrm{CO}_{2}$ conversions decreased steadily with decreasing temperatures, giving 
the lowest conversions of 1.9 and $4.5 \%$ respectively at $500{ }^{\circ} \mathrm{C}$. A similar trend was observed for the $\mathrm{H}_{2} / \mathrm{CO}$ ratio, which decreases as reaction temperature decreases, with the lowest ratio of 0.22 at $500{ }^{\circ} \mathrm{C}$. After the studying the temperature effect at $500{ }^{\circ} \mathrm{C}(150$ hours on stream), the reaction temperature was switched back to $850{ }^{\circ} \mathrm{C}$. It was found that the catalyst gave similar conversions at $850{ }^{\circ} \mathrm{C}$ after 150 hours as it did at $850{ }^{\circ} \mathrm{C}$ prior to the temperature study. This confirms that the catalyst shows no signs of deactivation after 150 hours and is extremely stable.

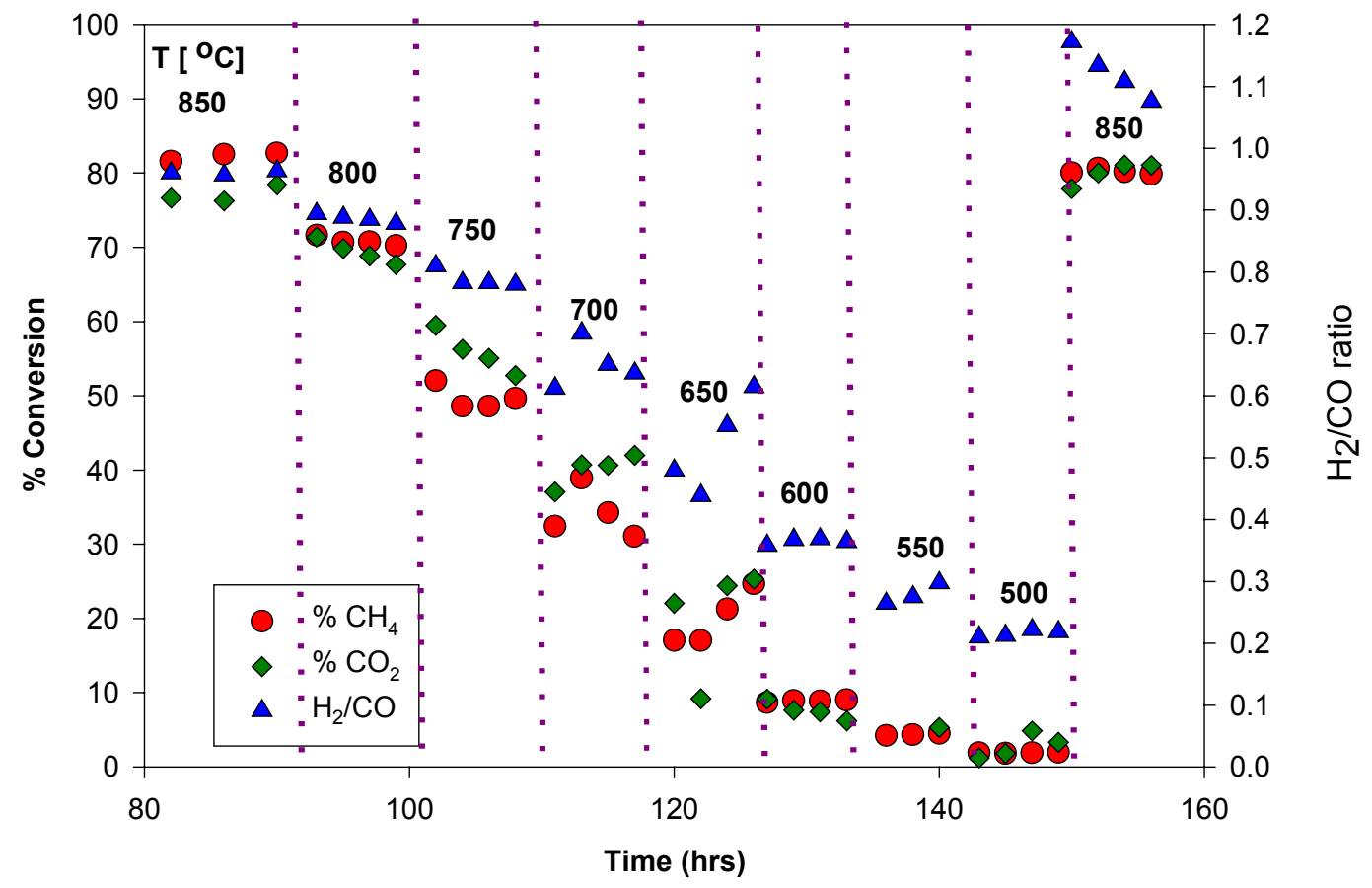

Figure 5.13 Effect of reaction temperature on the $\mathrm{Co}_{6} \mathrm{~W}_{6} \mathrm{C}$ catalyst activity for the $\mathrm{CO}_{2}$ reforming of $\mathrm{CH}_{4}$ (Particle size $<38 \mu \mathrm{m}, \mathrm{CH}_{4} / \mathrm{CO}_{2} / \mathrm{Ar}=1 / 1 / 3, \mathrm{P}_{\text {total }}=5 \mathrm{~atm}$., reactant $\left.\mathrm{WHSV}=4250 \mathrm{scc} / \mathrm{hr} / \mathrm{g}_{\text {catalyst }}\right)$

The increase in the catalytic activity prior to stabilization leads to a working hypothesis that the catalyst is undergoing certain phase transformations. X-ray diffraction patterns of the used catalyst support this hypothesis; these are discussed later (section 
5.3.4.1). The overall carbon balances obtained for these continuous experiments were 98-to-103 \%. Details of these calculations are given in Appendix E.

The rates of formation of different species at different reaction temperatures for a 1:1 feed ratio are given by Figure 5.14. Here, $\Delta \mathrm{CD}$ is the net rate of carbon deposition, as given by a carbon balance. The details of calculations of these experimental rates are given in Appendix E (eqn. E.8).

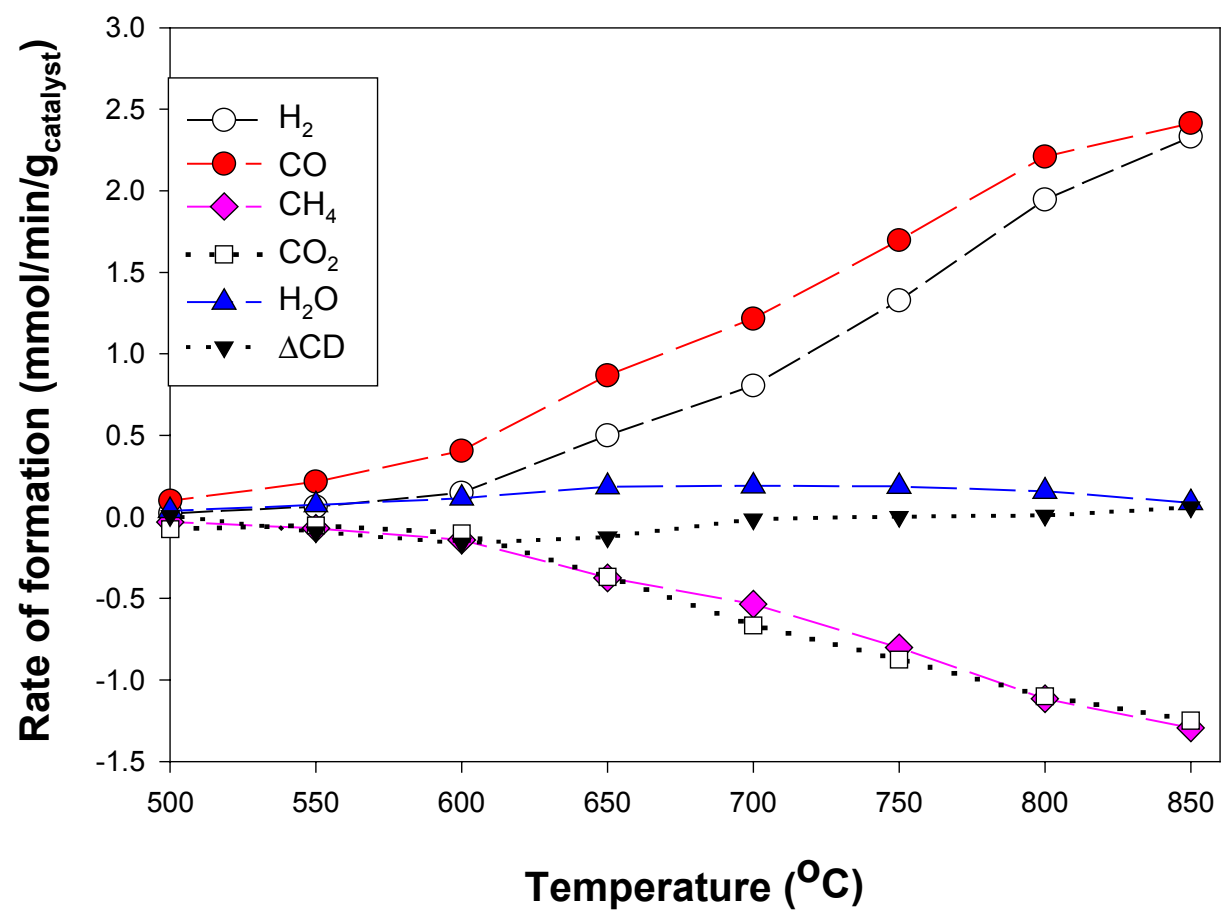

Figure 5.14 Effect of reaction temperature on the rates of formation of different reaction species for the $\mathrm{CO}_{2}$ reforming of $\mathrm{CH}_{4}$ with $\mathrm{Co}_{6} \mathrm{~W}_{6} \mathrm{C}$ catalyst (Particle size < $38 \mu \mathrm{m}, \mathrm{CH}_{4} / \mathrm{CO}_{2} / \mathrm{Ar}=1 / 1 / 3, \mathrm{P}_{\text {total }}=5 \mathrm{~atm}$., reactant $\mathrm{WHSV}=4250 \mathrm{scc} / \mathrm{hr} / \mathrm{g}_{\text {catalyst }}$, $\triangle \mathrm{CD}$ is the net carbon deposition as given by a carbon balance)

The rate of $\mathrm{CO}$ formation (Figure 5.14) is higher than that of $\mathrm{H}_{2}$ for all the temperatures except at $850{ }^{\circ} \mathrm{C}$, where the rates are almost equal. The $\mathrm{H}_{2} \mathrm{O}$ production rate is higher than that of $\mathrm{H}_{2}$ at temperatures below $600{ }^{\circ} \mathrm{C}$, but the two rates are 
comparable at $600{ }^{\circ} \mathrm{C}$. Typically, the $\mathrm{H}_{2}$ production increases with temperature. The $\mathrm{H}_{2} / \mathrm{CO}$ ratio increases gradually with reaction temperature and tends to unity at $850{ }^{\circ} \mathrm{C}$. The rate of water formation increases with temperature and reaches a maximum at 700 ${ }^{\circ} \mathrm{C}$, and then gradually decreases. The $\mathrm{CH}_{4}$ and $\mathrm{CO}_{2}$ rates are nearly equal to each other at all temperatures.

Table 5.1 compares the results of this work with the activity of various carbide catalysts used for $\mathrm{CO}_{2}$ reforming of $\mathrm{CH}_{4}$ with a 1:1 feed ratio. The activity changes with reaction conditions and support. The majority of the carbide catalysts operate at temperatures of about $850{ }^{\circ} \mathrm{C}$, which is higher than the typical operating conditions of the Ni-based catalysts. However, most of the Ni catalysts deactivate after about 10 to 30 hours on stream. Claridge et al. (1998) have shown that the molybdenum and tungsten carbide catalysts tend to deactivate at ambient pressures but are stable at higher pressures. Besides, Brungs et al. (1999) found that the niobium carbide ( $\mathrm{NbC}$ ) catalysts deactivate at $950{ }^{\circ} \mathrm{C}$ but are stable at $1050{ }^{\circ} \mathrm{C}$ and $1100{ }^{\circ} \mathrm{C}$. However, Tsuji et al. (2000) report a stable $\mathrm{Mo}_{2} \mathrm{C} / \mathrm{ZrO}_{2}$ catalyst that can operate at ambient pressures and at $850{ }^{\circ} \mathrm{C}$. 
Table 5.1. Summary of catalyst activity for various carbide catalysts for $\mathrm{CO}_{2}$ reforming of $\mathrm{CH}_{4}$ with a 1:1 feed ratio.

\begin{tabular}{|c|c|c|c|c|c|c|c|c|}
\hline \multirow[t]{2}{*}{ Catalyst System } & \multirow{2}{*}{$\begin{array}{c}\mathbf{T} \\
\left({ }^{\circ} \mathrm{C}\right)\end{array}$} & \multirow{2}{*}{$\begin{array}{c}\mathbf{P} \\
\text { (bar) }\end{array}$} & \multicolumn{2}{|c|}{$\begin{array}{c}\% \\
\text { Conversion } \\
\end{array}$} & \multirow{2}{*}{\begin{tabular}{|c|}
$\%$ \\
Yield \\
CO \\
\end{tabular}} & \multirow[t]{2}{*}{$\mathrm{H}_{2} / \mathrm{CO}$} & \multirow[t]{2}{*}{ Comment on catalyst stability } & \multirow[t]{2}{*}{ Reference } \\
\hline & & & $\mathrm{CH}_{4}$ & $\mathrm{CO}_{2}$ & & & & \\
\hline Unsupported $\mathrm{Co}_{6} \mathrm{~W}_{6} \mathrm{C}$ & 850 & 5 & 82 & 78 & 76 & 1.0 & stable for more than $150 \mathrm{~h}$ & current work \\
\hline $\mathrm{Mo}_{2} \mathrm{C} / \mathrm{SiO}_{2}$ & 950 & 8 & 91 & 86 & 89 & 0.95 & deactivation after $5 \mathrm{~h}$ & \multirow{4}{*}{$\begin{array}{l}\text { Brungs et al. } \\
(2000)\end{array}$} \\
\hline $\mathrm{Mo}_{2} \mathrm{C} / \mathrm{Al}_{2} \mathrm{O}_{3}$ & 950 & 8 & 89 & 86 & 87 & 0.97 & stable for more than $40 \mathrm{~h}$ & \\
\hline $\mathrm{Mo}_{2} \mathrm{C} / \mathrm{ZrO}_{2}$ & 950 & 8 & 90 & 93 & 92 & 0.96 & deactivation after $8 \mathrm{~h}$ & \\
\hline $\mathrm{Mo}_{2} \mathrm{C} / \mathrm{TiO}_{2}$ & 950 & 8 & 31 & 27 & 29 & --- & deactivation before $5 \mathrm{~h}$ & \\
\hline Unsupported $\mathrm{Mo}_{2} \mathrm{C} \mathrm{I}^{\mathrm{a}}$ & 850 & 1 & 12 & 32 & --- & 0.1 & $\begin{array}{l}\text { Conversion decreased to } 2 / 3^{\text {rd }} \text { of initial } \\
\text { conversion }\end{array}$ & \multirow{3}{*}{$\begin{array}{l}\text { Tsuji et al. } \\
(2000)\end{array}$} \\
\hline Unsupported $\mathrm{Mo}_{2} \mathrm{C} \mathrm{II}{ }^{\mathrm{a}}$ & 850 & 1 & 60 & 80 & --- & 0.4 & $\begin{array}{l}\text { Conversions decreased to } 90 \% \text { of initial } \\
\text { conversion in } 16 \text { h on stream }\end{array}$ & \\
\hline $\mathrm{Mo}_{2} \mathrm{C} / \mathrm{ZrO}_{2}$ & 850 & 1 & 9 & 18 & --- & --- & stable for more than $20 \mathrm{~h}$ & \\
\hline Unsupported WC & 850 & 1 & 90.7 & 99.7 & 86.6 & 1.1 & deactivation after $35 \mathrm{~h}$ & \multirow{4}{*}{$\begin{array}{l}\text { Shamsi and } \\
\text { Lyons }(2000)\end{array}$} \\
\hline $\mathrm{Mo}_{2} \mathrm{C}(\mathrm{me})^{\mathrm{b}}$ & 850 & 1 & 92.1 & 99.8 & 96 & 1.0 & --- & \\
\hline $\mathrm{Mo}_{2} \mathrm{C}(\mathrm{et})^{\mathrm{b}}$ & 850 & 1 & 89.5 & 99.9 & 89.4 & 1.1 & deactivation after $10 \mathrm{~h}$ & \\
\hline $\mathrm{Mo}_{2} \mathrm{C} / \mathrm{TiO}_{2}$ & 850 & 1 & 70.1 & 88.7 & 77.8 & 0.9 & stable for more than $2.5 \mathrm{~h}$ & \\
\hline Vanadium carbide (VC) & 950 & 8 & 75 & 90 & 80 & 1.1 & $\begin{array}{l}\text { Showed deactivation signs after } 10 \mathrm{~h} \text { on } \\
\text { stream }\end{array}$ & \multirow{3}{*}{$\begin{array}{l}\text { Brungs et al. } \\
\text { (1999) }\end{array}$} \\
\hline Niobium carbide $(\mathrm{NbC})^{\mathrm{c}}$ & 950 & 8 & 65 & 95 & 80 & 0.75 & deactivation after $10 \mathrm{~h}$ & \\
\hline Tantalum carbide $(\mathrm{TaC})$ & 950 & 8 & 45 & 85 & 0.55 & 65 & rapid deactivation & \\
\hline \multirow{3}{*}{$\beta-\mathrm{Mo}_{2} \mathrm{C}^{\mathrm{d}}$} & 850 & 8.3 & 62.5 & 75.9 & 69.5 & 0.78 & \multirow{4}{*}{ stable for more than $72 \mathrm{~h}$} & \multirow{5}{*}{$\begin{array}{l}\text { Claridge et al } \\
\text { (1998) }\end{array}$} \\
\hline & 900 & 8.3 & 73.5 & 83.7 & 78.8 & 0.83 & & \\
\hline & 950 & 8.3 & 83.3 & 89.5 & 86.5 & 0.88 & & \\
\hline$\alpha-W C^{d}$ & 850 & 8.3 & 62.7 & 75.4 & 68.6 & 0.79 & & \\
\hline$\beta-\mathrm{Mo}_{2} \mathrm{C} / \mathrm{Al}_{2} \mathrm{O}_{3}{ }^{\mathrm{d}}$ & 850 & 8.3 & 65.1 & 80.7 & 73.1 & 0.81 & --- & \\
\hline
\end{tabular}

${ }^{a}$ Unsupported $\mathrm{Mo}_{2} \mathrm{C} \mathrm{I}=\mathrm{Mo}_{2} \mathrm{C}$, while Unsupported $\mathrm{Mo}_{2} \mathrm{C} \mathrm{II}=\mathrm{MoC}_{1-\mathrm{x}}$, where $\mathrm{x} \sim 0.5 ;{ }^{\mathrm{b}} \mathrm{TPR}$ of $\mathrm{MoO}_{3}$ using $11.6 \%$ methane (me) or ethane (et) in $\mathrm{H}_{2}$ respectively; ${ }^{\mathrm{c}}$ stable at $1050{ }^{\circ} \mathrm{C}$ and $1100{ }^{\circ} \mathrm{C}$; ${ }^{\mathrm{d}}$ deactivation at ambient pressures. 


\section{Activation Energy}

The Arrhenius plots of the rates of production or consumption of the species for varying reaction temperatures are given in Figure 5.15. The corresponding values of the activation energies of the different reaction species are as tabulated in Table 5.2. These activation energies are evaluated for small particle size ( $<38$ microns), the initial catalytic activity, and for low reactant conversions. Therefore, these values represent the region where the reaction rate is temperature-sensitive and there are negligible external-diffusion limitations. Due to the insensitivity of the equipment, small changes in $\mathrm{CO}_{2}$ conversions could not be obtained without large errors. Hence, a value for the activation energy for $\mathrm{CO}_{2}$ was not obtained. Few kinetic data are available for the tungsten carbide systems. Also shown in Table 5.2 are values of the activation energies obtained in the literature for other catalyst systems. The ranges of the reported values in this investigation are comparable to those obtained for other catalyst systems in the literature.

Table 5.2. Activation energies for the $\mathrm{CO}_{2}$ reforming of $\mathrm{CH}_{4}$ over various catalyst systems

\begin{tabular}{|c|c|c|c|c|c|}
\hline \multirow{2}{*}{ Catalyst } & \multicolumn{4}{|c|}{$\mathbf{E}_{\mathbf{a}}(\mathbf{k c a l} / \mathbf{m o l})$} & \multirow{2}{*}{ Reference } \\
\cline { 2 - 5 } & $\mathbf{C H}_{\mathbf{4}}$ & $\mathbf{H}_{\mathbf{2}}$ & $\mathbf{C O}$ & $\mathbf{H}_{\mathbf{2}} \mathbf{O}$ & \\
\hline Unsupported $\mathrm{Co}_{6} \mathrm{~W}_{6} \mathrm{C}$ & 20.5 & 26.7 & 18.9 & 15.0 & current work \\
\hline $\mathrm{Ni} / \mathrm{SiO}_{2}$ & 23 & 27 & 20 & 18 & \multirow{2}{*}{ Bradford and Vannice (1996) } \\
\hline $\mathrm{Ni} / \mathrm{MgO}^{\mathrm{Ru}} / \mathrm{TiO}_{2}$ & 22 & 35 & 21 & 18 & \\
\hline $\mathrm{Ru} / \mathrm{Al}_{2} \mathrm{O}_{3}$ & 18 & 23 & 18 & --- & Bradford (1997) \\
\hline $\mathrm{Pd} / \mathrm{TiO}_{2}$ & --- & 18 & 16 & --- & Erdohelyi et al. $(1993)$ \\
\hline $\mathrm{Ir} / \mathrm{Al}_{2} \mathrm{O}_{3}$ & 18 & 25 & 16 & --- & Bradford (1997) \\
\hline $\mathrm{Ir} / \mathrm{TiO}_{2}$ & 21 & 23 & 16 & --- & Vernon et al. $(1992)$ \\
\hline $\mathrm{Pt} / \mathrm{ZrO}_{2}$ & 21 & 28 & 20 & --- & Bradford (1997) \\
\hline $\mathrm{Pt} / \mathrm{TiO}_{2}$ & 24 & 34 & 22 & --- & \multirow{2}{*}{ Bradford and Vannice (1998) } \\
\hline $\mathrm{Pt}$ powder & 23 & 32 & 20 & --- & \\
\hline & 18 & 18 & 22 & --- & \\
\hline
\end{tabular}




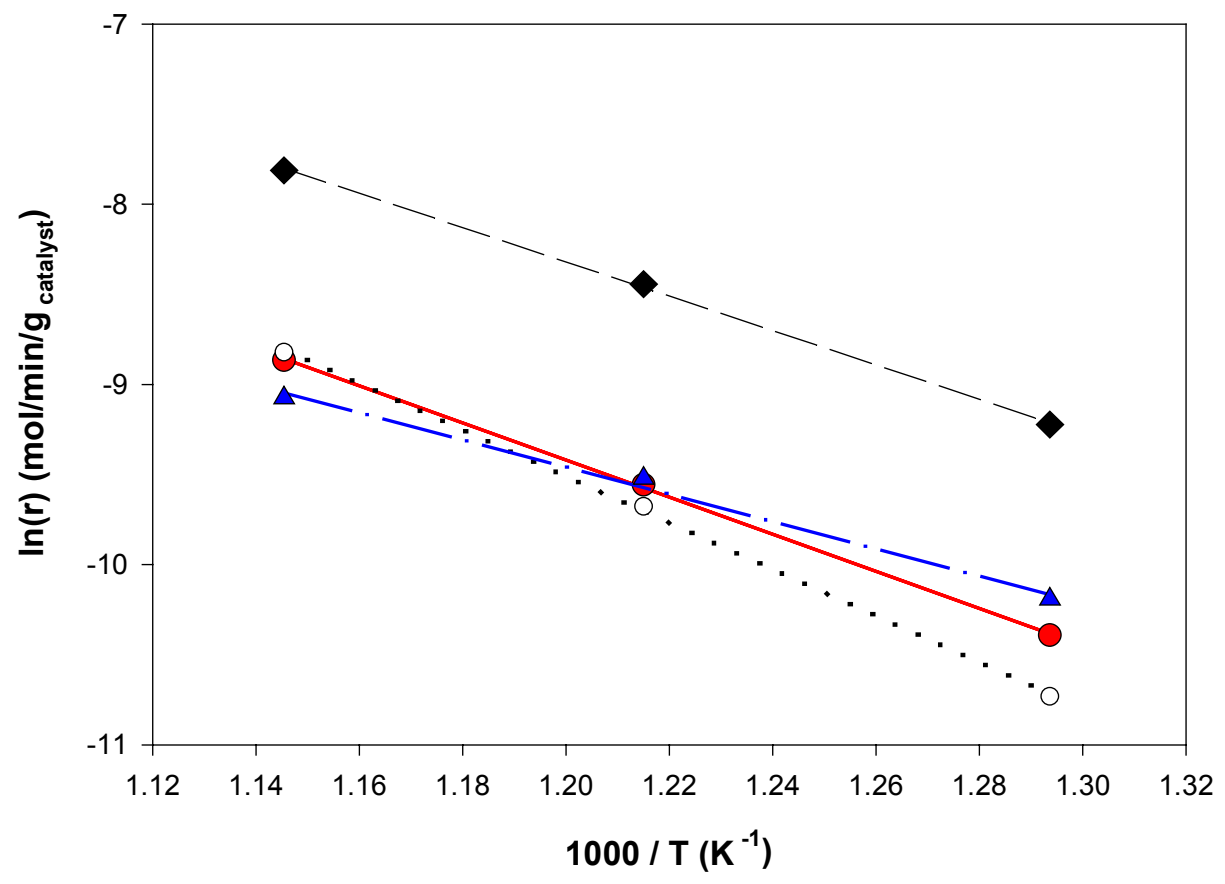

Figure 5.15 Arrhenius plots for initial $\mathrm{Co}_{6} \mathrm{~W}_{6} \mathrm{C}$ activity for $\mathrm{CH}_{4} / \mathrm{CO}_{2}$ reforming. (॰) $\mathrm{CH}_{4}$ consumption; (O) $\mathrm{H}_{2}$ production; ( $\left.\diamond\right)$ CO production; ( $\triangle$ ) $\mathrm{H}_{2} \mathrm{O}$ production. (Particle size $<38 \mu \mathrm{m}, \mathrm{CH}_{4} / \mathrm{CO}_{2} / \mathrm{Ar}=1 / 1 / 3, \mathrm{P}_{\text {total }}=5 \mathrm{~atm}$., reactant $\mathrm{WHSV}=4250$ $\mathbf{s c c} / \mathbf{h r} / \mathrm{g}_{\text {catalyst }}$ )

\subsubsection{Characterization of the Cobalt Tungsten Carbide Catalyst}

Characterization of the cobalt tungsten carbide $\left[\mathrm{Co}_{6} \mathrm{~W}_{6} \mathrm{C}\right]$ catalyst is achieved by X-ray diffraction (XRD) analysis and by Scanning Electron Microscope (SEM) analysis.

\subsubsection{X-ray Diffraction (XRD) Analysis}

The XRD patterns of the fresh and stabilized catalyst are given in Figure 5.16. Fresh catalyst is material as received. The stabilized catalyst consists of fresh catalyst subjected to a two-stage in-situ pretreatment. The first stage of pretreatment consists of 
flowing $\mathrm{H}_{2}(62 \mathrm{scc} / \mathrm{min})$ at $400{ }^{\circ} \mathrm{C}$ for 1 hour and then flushing the system with $\operatorname{Ar}(190$ $\mathrm{scc} / \mathrm{min})$ at $400{ }^{\circ} \mathrm{C}$ for 1 hour. The second stage of pretreatment is performed in a $\mathrm{CH}_{4} / \mathrm{CO}_{2} / \mathrm{Ar}=1 / 1 / 3$ flow at $850{ }^{\circ} \mathrm{C}$ and 5 bar total pressure for about 20 hours, at which time Figure 5.11 indicates that the catalyst is active and stable.

The XRD patterns show a change in the phase of the catalyst from $\mathrm{Co}_{6} \mathrm{~W}_{6} \mathrm{C}$ to a mixture of $\mathrm{WC}+\mathrm{Co}+\mathrm{C}$. The details of this phase transformation can be explained from the Co-W-C ternary phase diagram as given in Figure 5.17. Following Polizzotti et al. (1994), the fresh catalyst material $\left[\mathrm{Co}_{6} \mathrm{~W}_{6} \mathrm{C}\right]$ has a $\mathrm{Co} / \mathrm{W}$ atomic ratio of $1 / 1$. This fresh unused material is given as $\mathrm{M}_{12} \mathrm{C}$ in the figure, where $\mathrm{M}$ denotes the metal atoms $(\mathrm{Co}+\mathrm{W})$ and $\mathrm{C}$ denotes the carbon atom. The concentration of carbon in the material varies as given by tie line "1" as shown in Figure 5.17. This tie line is drawn from the carbon vertex (point $\mathrm{C}$ ) to the $50 \%$ atomic ratio point on the $\mathrm{Co} / \mathrm{W}$ binary composition base line (midpoint of line $\mathrm{Co}-\mathrm{W}$ ) as shown in the figure. The point $\mathrm{M}_{12} \mathrm{C}$ lies on this tie line "1". The concentration of carbon along the $\mathrm{Co} / \mathrm{W}$ binary composition base line (line $\mathrm{Co}-\mathrm{W})$ is zero. With the movement along the tie line " 1 " away from the $\mathrm{Co} / \mathrm{W}$ binary composition base line (line Co-W) and towards the carbon vertex (point C), the carbon concentration in the ternary system increases linearly.

As mentioned above, the XRD patterns reveal a phase transformation of the catalyst from $\mathrm{Co}_{6} \mathrm{~W}_{6} \mathrm{C}$ to a mixture of $\mathrm{WC}+\mathrm{Co}+\mathrm{C}$. These results are consistent with those reported by Claridge et al. (1998) and Brungs et al. (1999), where they observe formation of metal carbides but not of any oxides. The stability of these metal carbide catalysts is due to the carbide phase formed. Hence, coking is not a problem for these catalysts. 


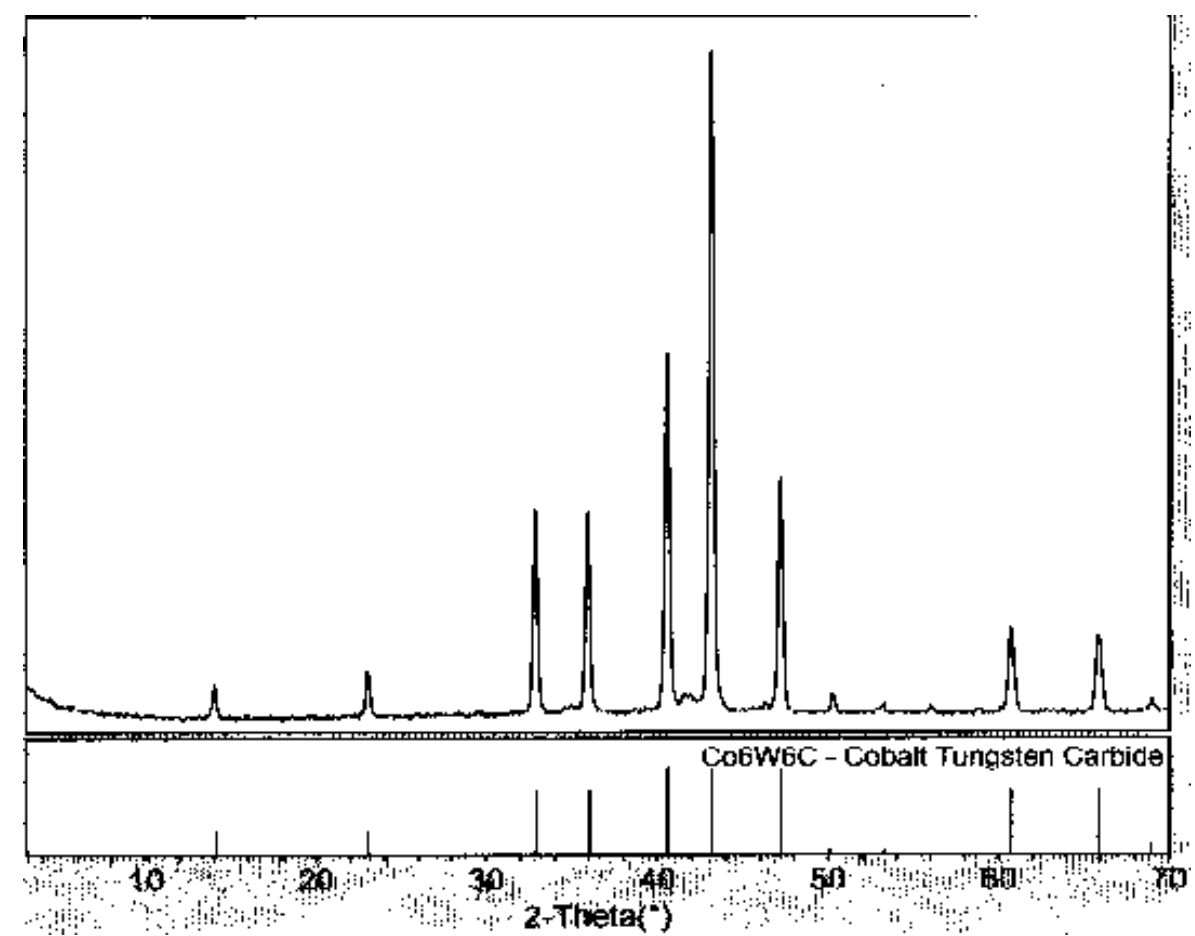

(a) fresh $\mathrm{Co}_{6} \mathrm{~W}_{6} \mathrm{C}$ catalyst (before stabilization)

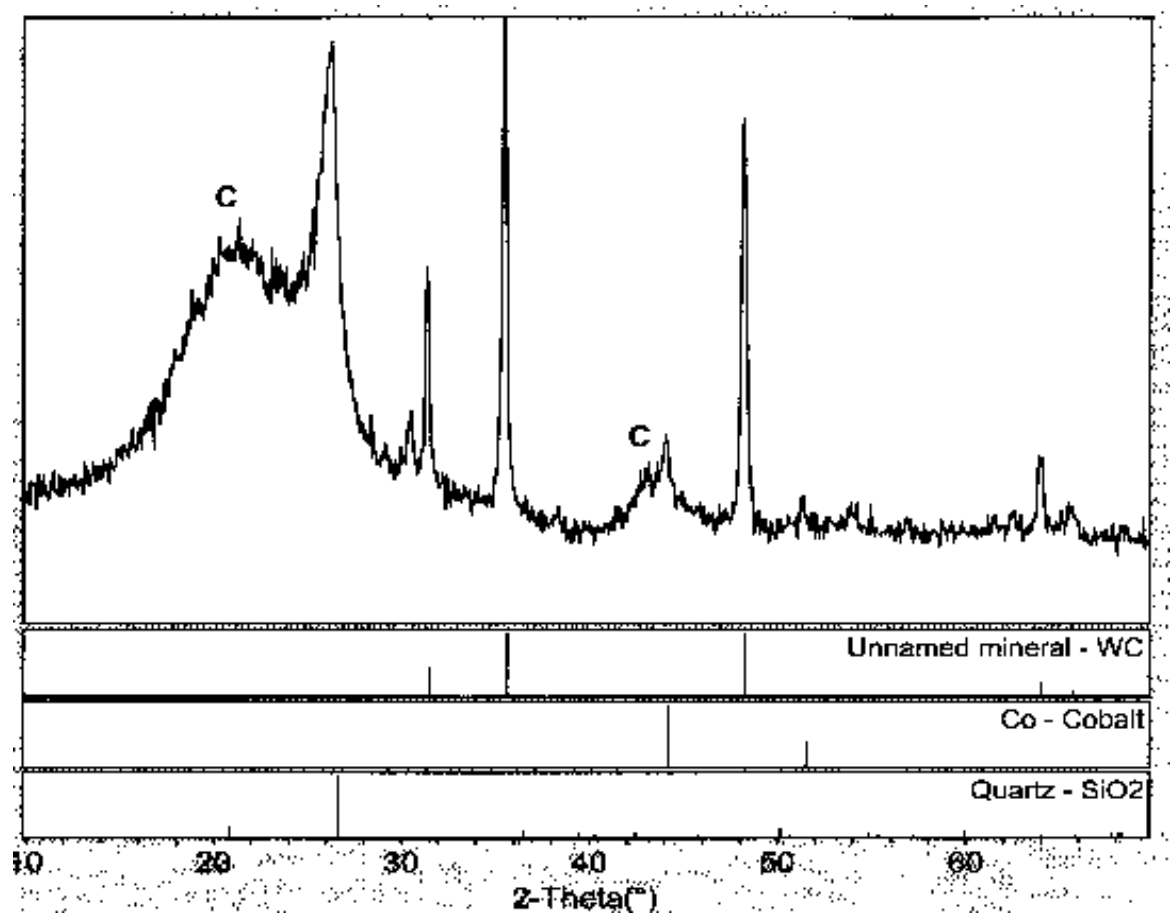

(b) after stabilization

Figure 5.16 XRD patterns of: (a) fresh $\mathrm{Co}_{6} \mathrm{~W}_{6} \mathrm{C}$ catalyst and (b) after stabilization; during $\mathrm{CH}_{4} / \mathrm{CO}_{2}$ reforming at $850^{\circ} \mathrm{C}$. (Particle size $<38 \mu \mathrm{m}, \mathrm{CH}_{4} / \mathrm{CO}_{2} / \mathrm{Ar}=1 / 1 / 3$, $P_{\text {total }}=5$ atm., reactant $\left.\mathrm{WHSV}=4250 \mathrm{scc} / \mathrm{hr} / \mathrm{g}_{\text {catalyst }}\right)$ 


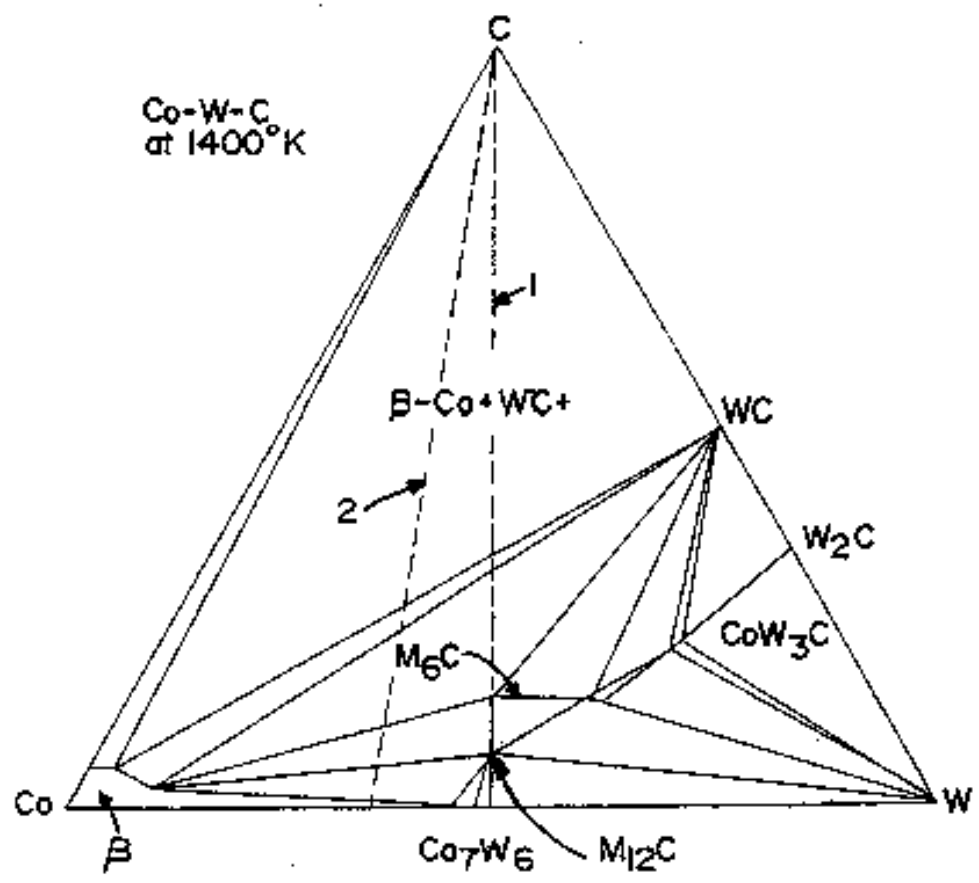

Figure 5.17 Ternary phase diagram of cobalt-tungsten-carbon (isothermal section at 1400 K), (Polizzotti et al., 1994).

However, these catalyst tend to deactivate by oxidation, via dissociative adsorption of $\mathrm{CO}_{2}$ which acts as the oxygen source (Brungs et al., 1999). The formation of these oxides, which cause the deactivation, is suppressed at elevated pressures (Claridge et al, 1998; Brungs et al., 1999). Consistent with these observations, we observe the formation of cobalt tungsten oxide $\left(\mathrm{CoWO}_{4}\right)$ when the catalyst system is exposed to ambient pressures at high temperatures: XRD pattern of a used catalyst at 850 ${ }^{\circ} \mathrm{C}$ and 1 atm. is shown in Figure 5.18. Similarly, Claridge et al. (1998) observe deactivation of these catalysts when they operate at ambient pressures. The XRD patterns of used tungsten carbide catalysts at ambient pressures by Shamsi and Lyons (2000) show the presence of tungsten oxide. It is interesting to note that their catalyst shows deactivation as well as formation of oxides, which is consistent with the observations of Claridge et al. (1998). However, Tsuji et al. (2000) have reported stable 
$\mathrm{Mo}_{2} \mathrm{C}$ catalysts, which can operate even at ambient pressures. They suppress the deactivation by nitriding the oxide before carburization and by lowering the $\mathrm{Mo}_{2} \mathrm{C}$ loading on the zirconia support.

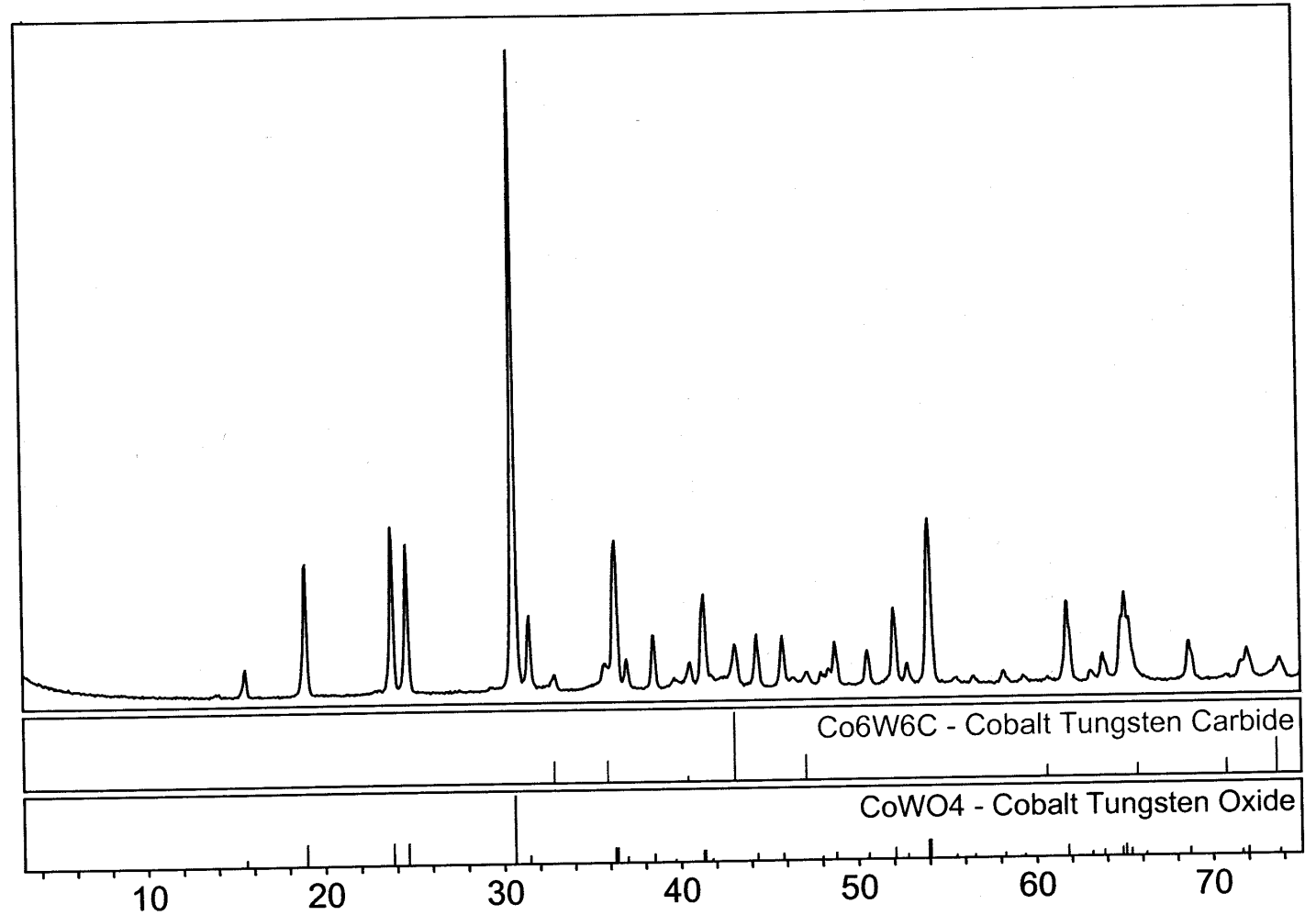

Figure 5.18 XRD pattern of $\mathrm{Co}_{6} \mathrm{~W}_{6} \mathrm{C}$ catalyst when exposed to ambient pressure after $\mathrm{CH}_{4} / \mathrm{CO}_{2}$ reforming.

Claridge et al. (1998) propose two competing mechanisms by which the metal carbide catalysts operate: the redox mechanism and the noble-metal mechanism. The details are as given in Section 2.5.3 earlier. However, Claridge et al. (1998) and Brungs et al. (1999) put forward the redox-type mechanism to explain the stability of these carbide catalysts. Briefly, the redox mechanism reports the formation of transition metal oxides followed by carburization of these oxides to give back metal carbides. Carburization of these oxides back to metal carbides preserves the stability of the 
catalyst. Carburization is achieved only at very high temperatures in the presence of the $\mathrm{CH}_{4} / \mathrm{CO}_{2}$ reaction mixture, as governed by thermodynamics (Brungs et al., 1999). See Section 2.5.3 for further details. This explains the higher operating/pretreatment temperatures required by the carbide catalysts.

\subsubsection{Scanning Electron Microscopy (SEM) Analysis}

Figure 5.19 shows the images obtained from scanning electron microscopy (SEM) of the carbon deposits on the cobalt-tungsten carbide catalyst after the dry reforming of methane at $850{ }^{\circ} \mathrm{C}$ and $5 \mathrm{~atm}$. These images suggest the formation of encapsulated carbon as well as whisker carbon. These are similar to the carbon whiskers formed on $\mathrm{Ni}$ catalysts (Luo et al., 2000). Claridge et al. (1998) did not find any evidence of macroscopic carbon formation on the carbide catalysts during methane dry reforming. They concluded that both molybdenum and tungsten carbide catalyst behave like noble metals and possess a kinetic barrier for carbon deposition. However, in our catalyst system, the presence of cobalt (a transition element) could possibly promote carbon formation. This is consistent with the reports of Guerrero-Ruiz et al. (1994) where they observed large amounts of carbon deposits with cobalt catalysts. 


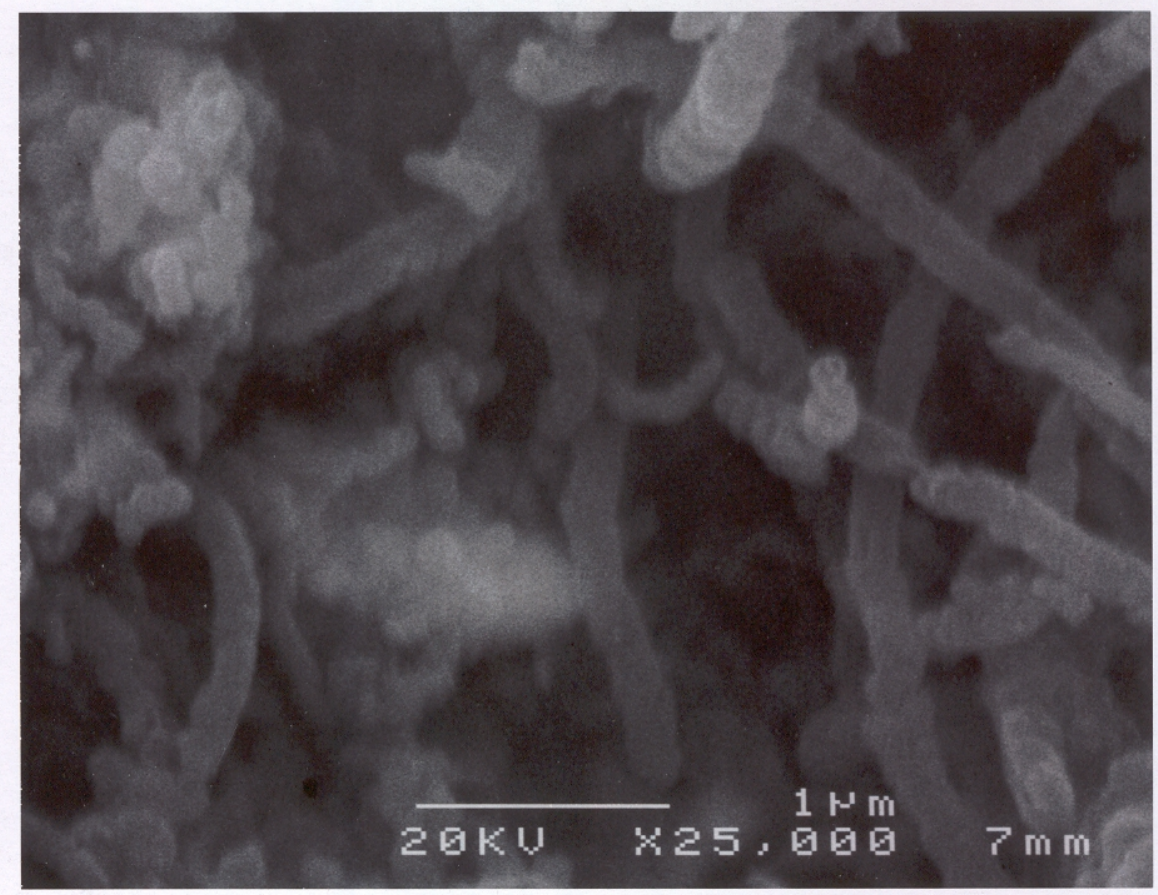

(a)

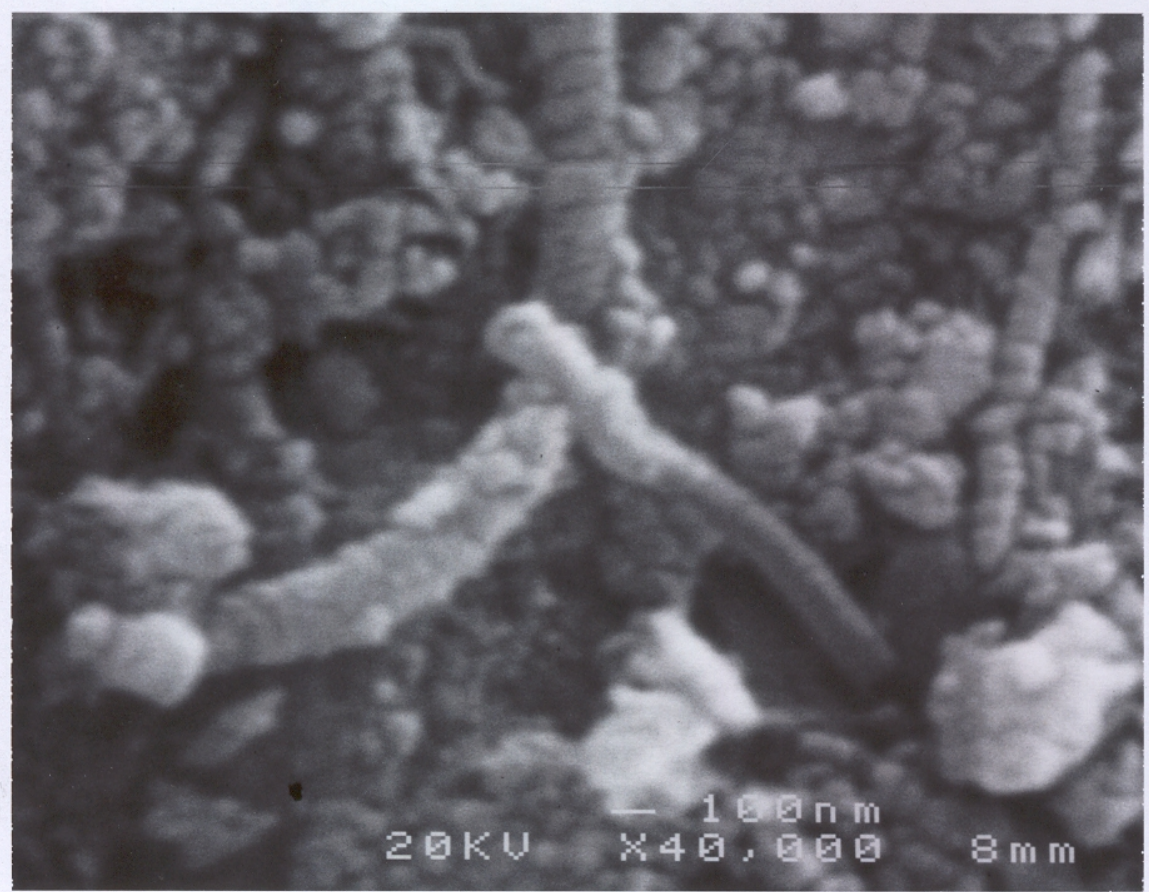

(b)

Figure 5.19 SEM images of the carbon deposits on the Co-WC catalyst after the $\mathrm{CH}_{4} / \mathrm{CO}_{2}$ reforming at $850^{\circ} \mathrm{C}\left(\mathrm{CH}_{4} / \mathrm{CO}_{2} / \mathrm{Ar}=1 / 1 / 3, \mathrm{P}_{\text {total }}=5 \mathrm{~atm}.\right)$ 


\subsection{Summary}

The cobalt tungsten carbide material used as catalyst for $\mathrm{CO}_{2}$ reforming of $\mathrm{CH}_{4}$ was found to be very stable for more than 90 hours at elevated pressures and high temperatures. The catalyst shows stabilization with increasing activity when heated at $850{ }^{\circ} \mathrm{C}$ in the presence of the feed mixture at $850^{\circ} \mathrm{C}$ and $5 \mathrm{~atm}$. total pressure, for over 20 hours. The stabilized catalyst yields $\mathrm{CH}_{4}$ and $\mathrm{CO}_{2}$ rates of 1.3 and $1.25 \mathrm{mmol} / \mathrm{min} / \mathrm{g}$ respectively (Figure 5.14), with $\mathrm{CO}$ yields of $76 \%$ and $\mathrm{H}_{2} / \mathrm{CO}$ ratio close to unity at $850^{\circ} \mathrm{C}$ and 5 atm. total pressure. Based on the reaction rates at low conversions, activation energies of $15-27 \mathrm{kcal} / \mathrm{mol}$ for different reaction species are obtained. These are consistent with the reported values from other studies. XRD patterns of the transformed catalyst suggest a phase transformation, at $850{ }^{\circ} \mathrm{C}$, from $\mathrm{Co}_{6} \mathrm{~W}_{6} \mathrm{C}$ to a mixture of $\mathrm{WC}+\mathrm{Co}+\mathrm{C}$. Scanning electron microscopy (SEM) images suggest the formation of encapsulated carbon as well as whisker carbon. These macroscopic carbon deposits could be due to the presence of Co in the catalyst, which is known to enhance carbon formation. 


\section{CHAPTER 6}

\section{REACTION KINETICS AND MODELING UNDER DIFFERENTIAL CONDITIONS}

\subsection{Introduction}

Until recent times, there have been only a few reports on kinetic studies of methane dry reforming cited in the literature (as seen in section 2.5). Most of the research efforts have been focused on the preparation of catalysts, evaluating the catalyst performance and understanding the thermodynamics of the reaction system. There have been various reports where the kinetics of methane dry reforming with carbon dioxide have been expressed as a simple power-law model due to its simplicity in application. However, over a wide range of partial-pressure data, these models are inadequate. Hence, it becomes necessary to understand the mechanistic aspects of the reforming reaction, based on which some researchers have proposed Langmuir-Hinshelwood, EleyRideal and Hougen-Watson type of reaction models.

In this study, a kinetic model for the carbon dioxide reforming of methane with the cobalt tungsten carbide $\left[\mathrm{Co}_{6} \mathrm{~W}_{6} \mathrm{C}\right]$ precursor has been developed from the results of a set of designed experiments. The experiments were performed under differential reaction conditions over a temperature range of $500-600{ }^{\circ} \mathrm{C}$. The initial modeling was based on a simple power-law model. This was followed by a Langmuir-Hinshelwood type of reaction model, based on a simple reaction mechanism proposed for the system. 


\subsection{Final Methodology}

\subsubsection{Catalyst Pretreatment}

The unsupported cobalt tungsten carbide material $\left[\mathrm{Co}_{6} \mathrm{~W}_{6} \mathrm{C}\right]$ to be used as a catalyst precursor for methane dry reforming was obtained from Nanodyne Inc. Typically, $300 \mathrm{mg}$ of the material of particle size $<38 \mu \mathrm{m}$ (400 mesh) was tested in each run. The details of this catalyst testing are discussed in Chapter 5. However, from this testing, it was observed that the stabilization of the catalyst-precursor in the reaction mixture at $850{ }^{\circ} \mathrm{C}$ was essential. Hence, the pretreatment procedure was now modified to a two-stage process discussed subsequently.

The first stage of the pretreatment was performed at atmospheric pressure by flowing $\mathrm{H}_{2}(62 \mathrm{scc} / \mathrm{min})$ at $400{ }^{\circ} \mathrm{C}$ for 1 hour. The system was later flushed with $\operatorname{Ar}(190$ $\mathrm{scc} / \mathrm{min}$ ) at $400{ }^{\circ} \mathrm{C}$ for 1 hour. Ar was used an inert and $\mathrm{He}$ was the internal standard.

In the second stage, the feed mixture was introduced with a feed ratio of $\mathrm{CH}_{4}: \mathrm{CO}_{2}: \mathrm{Ar}=1: 1: 3 . \quad$ The total weight hourly space velocity (WHSV) of the feed mixture was maintained at $11,200 \mathrm{scc} / \mathrm{hr} /$ gcat. The total pressure was raised to $5 \mathrm{~atm}$ maintaining the temperature at $400{ }^{\circ} \mathrm{C}$. The reaction temperature was then increased to $850{ }^{\circ} \mathrm{C}$ with the reactants flowing. Prior catalyst testing (section 5.3.3) had shown that the catalyst activity increases with time at $850{ }^{\circ} \mathrm{C}$ and the catalyst stabilizes to reach a certain maximum activity within a time span of about 24 hours. Hence, prior to any kinetic experiment the catalyst was stabilized at $850{ }^{\circ} \mathrm{C}$ for about 50 hours. The catalyst activity was noted every hour to confirm that the catalyst had reached its high activity. The kinetic experiments were then subsequently carried out. 


\subsubsection{Experimental Design}

The variables considered for the kinetic study were reaction temperature and partial pressures of methane, carbon dioxide, hydrogen, carbon monoxide and water. The independent variables are the reaction temperature and the partial pressures of methane, carbon dioxide and inert (Ar), obtained from the inlet feed stream. The dependent variables comprise the partial pressures of hydrogen, carbon monoxide and water, obtained from the product stream. The experiments were performed under differential reaction conditions (i.e. total reactant conversions of approximately $10 \%$ ) over a temperature range of $500-600{ }^{\circ} \mathrm{C}$. The total weight hourly space velocity (WHSV) of the feed mixture was maintained at $11,200 \mathrm{scc} / \mathrm{hr} / \mathrm{gcat}$. The total operating pressure was fixed at $5 \mathrm{~atm}$. The partial pressure of each of the reactant was varied from 0.5 to about 4 atm, retaining the partial pressure of the other reactant at $1 \mathrm{~atm}$. The details of the experiments are as listed in Table 6.1.

The reaction temperature was first held constant at $600{ }^{\circ} \mathrm{C}$ for approximately 2 hours before starting any run at that specific temperature. Each run was then carried out for 2 hours. After collecting all the data at that temperature, the catalyst activity was subsequently checked for any possible deactivation at $850{ }^{\circ} \mathrm{C}$ with a feed ratio of $\mathrm{CH}_{4}: \mathrm{CO}_{2}: \mathrm{Ar}=1: 1: 3$. However, no significant change in the catalyst activity was observed for repeated runs at $850{ }^{\circ} \mathrm{C}$. Hence, the possibility of catalyst deactivation during the runs was ruled out. After performing the set of experiments at $600{ }^{\circ} \mathrm{C}$ (and checking for deactivation at $850{ }^{\circ} \mathrm{C}$ ), the reaction temperature was then lowered to $550{ }^{\circ} \mathrm{C}$ and then subsequently to $500{ }^{\circ} \mathrm{C}$, and the above procedure was repeated at every temperature. The product samples downstream of the reactor were analyzed on-line at 15 
min. intervals. The reactor reaches steady state between $30-45 \mathrm{~min}$. The data were obtained from the samples collected after the first hour of the run.

Table 6.1 Experimental design for the kinetic study of the $\mathrm{CO}_{2}$ reforming of $\mathrm{CH}_{4}$ with $\mathrm{Co}_{6} \mathrm{~W}_{6} \mathrm{C}$ catalyst (Particle size $<38 \mu \mathrm{m}$, weight of catalyst used $=0.3 \mathrm{~g}$, Total feed $W H S V=11,200 \mathrm{scc} / \mathrm{hr} /$ g-catalyst., $P_{\text {total }}=5 \mathrm{~atm}$.)

\begin{tabular}{|c|c|c|c|c|c|}
\hline \multirow{2}{*}{ Label } & \multirow{2}{*}{$\mathrm{T}\left({ }^{0} \mathrm{C}\right)$} & \multicolumn{3}{|c|}{ Partial Pressure (atm.) } & \multirow{2}{*}{ Sequence } \\
\hline & & $\mathrm{CH}_{4}$ & $\mathrm{CO}_{2}$ & $\mathbf{A r}$ & \\
\hline AA & 600 & 1 & 0.5 & 3.5 & 1 \\
\hline $\mathrm{AB}$ & 600 & 1 & 1 & 3 & 2,7 \\
\hline $\mathrm{AC}$ & 600 & 1 & 2 & 2 & 3 \\
\hline $\mathrm{AD}$ & 600 & 1 & 3 & 1 & 4 \\
\hline $\mathrm{AE}$ & 600 & 1 & 4 & 0 & 5 \\
\hline $\mathrm{AF}$ & 600 & 0.5 & 1 & 3.5 & 6 \\
\hline AG & 600 & 2 & 1 & 2 & 8 \\
\hline $\mathrm{AH}$ & 600 & 3 & 1 & 1 & 9 \\
\hline $\mathrm{AI}$ & 600 & 4 & 1 & 0 & 10 \\
\hline$\overline{B A}$ & 550 & 1 & 0.5 & 3.5 & 11 \\
\hline BB & 550 & 1 & 1 & 3 & 12,17 \\
\hline $\mathrm{BC}$ & 550 & 1 & 2 & 2 & 13 \\
\hline BD & 550 & 1 & 3 & 1 & 14 \\
\hline $\mathrm{BE}$ & 550 & 1 & 4 & 0 & 15 \\
\hline $\mathrm{BF}$ & 550 & 0.5 & 1 & 3.5 & 16 \\
\hline BG & 550 & 2 & 1 & 2 & 18 \\
\hline $\mathrm{BH}$ & 550 & 3 & 1 & 1 & 19 \\
\hline BI & 550 & 4 & 1 & 0 & 20 \\
\hline CA & 500 & 1 & 0.5 & 3.5 & 21 \\
\hline $\mathrm{CB}$ & 500 & 1 & 1 & 3 & 22,27 \\
\hline $\mathrm{CC}$ & 500 & 1 & 2 & 2 & 23 \\
\hline $\mathrm{CD}$ & 500 & 1 & 3 & 1 & 24 \\
\hline $\mathrm{CE}$ & 500 & 1 & 4 & 0 & 25 \\
\hline $\mathrm{CF}$ & 500 & 0.5 & 1 & 3.5 & 26 \\
\hline CG & 500 & 2 & 1 & 2 & 28 \\
\hline $\mathrm{CH}$ & 500 & 3 & 1 & 1 & 29 \\
\hline CI & 500 & 4 & 1 & 0 & 30 \\
\hline
\end{tabular}




\subsection{Results and Discussion of Differential Runs}

\subsubsection{Effect of partial pressure of the reactants}

The effect of the partial pressure on the catalyst activity is obtained based on the experiments of Table 6.1. All the experiments were performed under differential reaction conditions with total reactant conversions of approximately $10 \%$. The major reaction products consisted of carbon monoxide, hydrogen and water. Table 6.2 gives the partial pressure data of all the reaction species for every run. The details of the calculation for the partial pressures and the rates of formation are given in Appendix E. The overall carbon balances obtained for these experiments were between 101-103\%. Table 6.3 gives the rates of formation of the products $\left(\mathrm{H}_{2}, \mathrm{CO}, \mathrm{H}_{2} \mathrm{O}\right)$ for all the runs.

Figures 6.1, 6.2 and 6.3 show the rates of formation for $\mathrm{H}_{2}, \mathrm{CO}$ and $\mathrm{H}_{2} \mathrm{O}$ at 600 , 550 and $500{ }^{\circ} \mathrm{C}$ respectively. The rate of formation of $\mathrm{CO}$ is always higher than that of both $\mathrm{H}_{2}$ and $\mathrm{H}_{2} \mathrm{O}$ combined. This is true for all reaction conditions. Besides, the rate of formation of $\mathrm{H}_{2}$ becomes less than that of $\mathrm{H}_{2} \mathrm{O}$ for decreasing reaction temperatures. Figures $6.4,6.5$ and 6.6 show the trends of the rates of formation for $\mathrm{CO}, \mathrm{H}_{2}$ and $\mathrm{H}_{2} \mathrm{O}$ respectively at every reaction temperature. These figures clearly show an increase in the magnitude of the rates for increasing temperatures. The rates of $\mathrm{CO}$ and $\mathrm{H}_{2} \mathrm{O}$ formation depend on the partial pressure of $\mathrm{CO}_{2}$ to a greater extent than they depend on that of $\mathrm{CH}_{4}$, as shown by Figures 6.4 and 6.6. On the other hand, the rate of $\mathrm{H}_{2}$ formation is governed mostly by the partial pressure of $\mathrm{CH}_{4}$. 
Table 6.2 Partial pressure data at reactor outlet for the kinetic study of the $\mathrm{CO}_{2}$ reforming of $\mathrm{CH}_{4}$ (Particle size $<38 \mu \mathrm{m}$, weight of catalyst used $=0.3 \mathrm{~g}$, Total feed $\mathrm{WHSV}=11,200 \mathrm{scc} / \mathrm{hr} / \mathrm{g}$-catalyst., $P_{\text {total }}=5 \mathrm{~atm}$.)

\begin{tabular}{|c|c|c|c|c|c|c|c|c|}
\hline \multirow{2}{*}{ Sequence } & \multirow{2}{*}{ Label } & \multicolumn{7}{|c|}{ Partial Pressure (atm.) } \\
\hline & & $\mathrm{CH}_{4}$ & $\mathrm{CO}_{2}$ & $\mathbf{H}_{2}$ & CO & $\mathrm{H}_{2} \mathrm{O}$ & He & Ar \\
\hline 1 & AA & 0.8527 & 0.4336 & 0.0703 & 0.1534 & 0.0414 & 0.1009 & 3.3477 \\
\hline 2 & $\mathrm{AB}$ & 0.8181 & 0.7933 & 0.0883 & 0.2337 & 0.0673 & 0.0998 & 2.8993 \\
\hline 3 & $\mathrm{AC}$ & 0.8290 & 1.6030 & 0.1007 & 0.3455 & 0.1029 & 0.1049 & 1.9140 \\
\hline 4 & $\mathrm{AD}$ & 0.8278 & 2.4075 & 0.1068 & 0.4314 & 0.1352 & 0.1078 & 0.9835 \\
\hline 5 & $\mathrm{AE}$ & 0.8435 & 3.2954 & 0.1050 & 0.4925 & 0.1528 & 0.1108 & 0 \\
\hline 6 & $\mathrm{AF}$ & 0.3427 & 0.7089 & 0.0645 & 0.1958 & 0.0561 & 0.0445 & 3.5876 \\
\hline 7 & $\mathrm{AB}$ & 0.8124 & 0.8532 & 0.0832 & 0.2282 & 0.0646 & 0.0985 & 2.8600 \\
\hline 8 & $\mathrm{AG}$ & 1.5671 & 0.7444 & 0.1233 & 0.2663 & 0.0693 & 0.1872 & 2.0424 \\
\hline 9 & $\mathrm{AH}$ & 2.4149 & 0.7641 & 0.1311 & 0.2695 & 0.0687 & 0.2853 & 1.0665 \\
\hline 10 & $\mathrm{AI}$ & 3.3429 & 0.7915 & 0.1353 & 0.2687 & 0.0677 & 0.3938 & 0 \\
\hline 11 & BA & 0.8884 & 0.4874 & 0.0303 & 0.0874 & 0.0285 & 0.1017 & 3.3762 \\
\hline 12 & $\mathrm{BB}$ & 0.8628 & 0.9236 & 0.0342 & 0.1268 & 0.0445 & 0.1001 & 2.9081 \\
\hline 13 & $\mathrm{BC}$ & 0.9115 & 1.7315 & 0.0394 & 0.1830 & 0.0660 & 0.1075 & 1.9613 \\
\hline 14 & $\mathrm{BD}$ & 0.9328 & 2.6140 & 0.0373 & 0.2151 & 0.0792 & 0.1108 & 1.0108 \\
\hline 15 & $\mathrm{BE}$ & 0.9480 & 3.5727 & 0.0357 & 0.2423 & 0.0882 & 0.1131 & 0 \\
\hline 16 & $\mathrm{BF}$ & 0.3784 & 0.7985 & 0.0248 & 0.1008 & 0.0360 & 0.0449 & 3.6167 \\
\hline 17 & BB & 0.8712 & 0.9017 & 0.0361 & 0.1240 & 0.0422 & 0.1007 & 2.9242 \\
\hline 18 & BG & 1.6527 & 0.8153 & 0.0528 & 0.1502 & 0.0486 & 0.1914 & 2.0889 \\
\hline 19 & BH & 2.5364 & 0.8127 & 0.0573 & 0.1528 & 0.0485 & 0.2939 & 1.0985 \\
\hline 20 & BI & 3.4827 & 0.8534 & 0.0581 & 0.1526 & 0.0483 & 0.4049 & 0 \\
\hline 21 & CA & 0.9098 & 0.4932 & 0.0165 & 0.0539 & 0.0186 & 0.1026 & 3.4054 \\
\hline 22 & $\mathrm{CB}$ & 0.9010 & 0.9085 & 0.0174 & 0.0736 & 0.0280 & 0.1022 & 2.9693 \\
\hline 23 & $\mathrm{CC}$ & 0.9453 & 1.8080 & 0.0182 & 0.1039 & 0.0415 & 0.1082 & 1.9749 \\
\hline 24 & CD & 0.9705 & 2.7263 & 0.0154 & 0.1140 & 0.0465 & 0.1114 & 1.0160 \\
\hline 25 & CE & 0.9797 & 3.6354 & 0.0256 & 0.1723 & 0.0722 & 0.1147 & 0 \\
\hline 26 & $\mathrm{CF}$ & 0.3995 & 0.8485 & 0.0079 & 0.0463 & 0.0184 & 0.0451 & 3.6344 \\
\hline 27 & $\mathrm{CB}$ & 0.8963 & 0.9195 & 0.0185 & \begin{tabular}{|l|l}
0.0769 \\
\end{tabular} & 0.0293 & 0.1018 & 2.9576 \\
\hline 28 & $\mathrm{CG}$ & 1.6978 & 0.8677 & 0.0207 & 0.0784 & 0.0293 & 0.1936 & 2.1124 \\
\hline 29 & $\mathrm{CH}$ & 2.5748 & 0.8926 & 0.0224 & 0.0807 & 0.0301 & 0.2953 & 1.1040 \\
\hline 30 & CI & 3.5857 & 0.8663 & 0.0239 & 0.0805 & 0.0296 & 0.4140 & 0 \\
\hline
\end{tabular}


Table 6.3 Rates of production of the reaction products for the kinetic study of the $\mathrm{CO}_{2}$ reforming of $\mathrm{CH}_{4}$ (Particle size $<38 \mu \mathrm{m}$, weight of catalyst used $=0.3 \mathrm{~g}$, Total feed $W H S V=11,200 \mathrm{scc} / \mathrm{hr} / \mathrm{g}$-catalyst., $P_{\text {total }}=5 \mathrm{~atm}$.)

\begin{tabular}{|c|c|c|c|c|}
\hline \multirow[t]{2}{*}{ Sequence } & \multirow[t]{2}{*}{ Label } & \multicolumn{3}{|c|}{$\begin{array}{l}\text { observed rate of production } \\
\text { (mmol/min/g-catalyst) }\end{array}$} \\
\hline & & $\mathbf{H}_{2}$ & $\mathrm{CO}$ & $\mathrm{H}_{2} \mathrm{O}$ \\
\hline 1 & AA & 0.1218 & 0.2659 & 0.0717 \\
\hline 2 & $\mathrm{AB}$ & 0.1546 & 0.4092 & 0.1179 \\
\hline 3 & $\mathrm{AC}$ & 0.1679 & 0.5758 & 0.1715 \\
\hline 4 & $\mathrm{AD}$ & 0.1731 & 0.6992 & 0.2192 \\
\hline 5 & $\mathrm{AE}$ & 0.1657 & 0.7772 & 0.2412 \\
\hline 6 & $\mathrm{AF}$ & 0.1199 & 0.3641 & 0.1043 \\
\hline 7 & $\mathrm{AB}$ & 0.1476 & 0.4050 & 0.1146 \\
\hline 8 & AG & 0.2363 & 0.5106 & 0.1328 \\
\hline 9 & $\mathrm{AH}$ & 0.2494 & 0.5128 & 0.1307 \\
\hline 10 & AI & 0.2497 & 0.4959 & 0.1250 \\
\hline 11 & BA & 0.0521 & 0.1502 & 0.0490 \\
\hline 12 & BB & 0.0597 & 0.2213 & 0.0776 \\
\hline 13 & $\mathrm{BC}$ & 0.0640 & 0.2976 & 0.1073 \\
\hline 14 & $\mathrm{BD}$ & 0.0588 & 0.3392 & 0.1249 \\
\hline 15 & $\mathrm{BE}$ & 0.0552 & 0.3745 & 0.1363 \\
\hline 16 & $\mathrm{BF}$ & 0.0457 & 0.1860 & 0.0664 \\
\hline 17 & BB & 0.0626 & 0.2153 & 0.0732 \\
\hline 18 & BG & 0.0990 & 0.2816 & 0.0911 \\
\hline 19 & BH & 0.1058 & 0.2823 & 0.0896 \\
\hline 20 & BI & 0.1044 & 0.2740 & 0.0867 \\
\hline 21 & CA & 0.0281 & 0.0918 & 0.0317 \\
\hline 22 & $\mathrm{CB}$ & 0.0297 & 0.1259 & 0.0478 \\
\hline 23 & $\mathrm{CC}$ & 0.0294 & 0.1678 & 0.0670 \\
\hline 24 & $\mathrm{CD}$ & 0.0241 & 0.1789 & 0.0729 \\
\hline 25 & $\mathrm{CE}$ & 0.0391 & 0.2628 & 0.1100 \\
\hline 26 & $\mathrm{CF}$ & 0.0144 & 0.0851 & 0.0337 \\
\hline 27 & $\mathrm{CB}$ & 0.0318 & 0.1320 & 0.0503 \\
\hline 28 & CG & 0.0384 & 0.1454 & 0.0543 \\
\hline 29 & $\mathrm{CH}$ & 0.0411 & 0.1484 & 0.0554 \\
\hline 30 & CI & 0.0420 & 0.1413 & 0.0519 \\
\hline
\end{tabular}




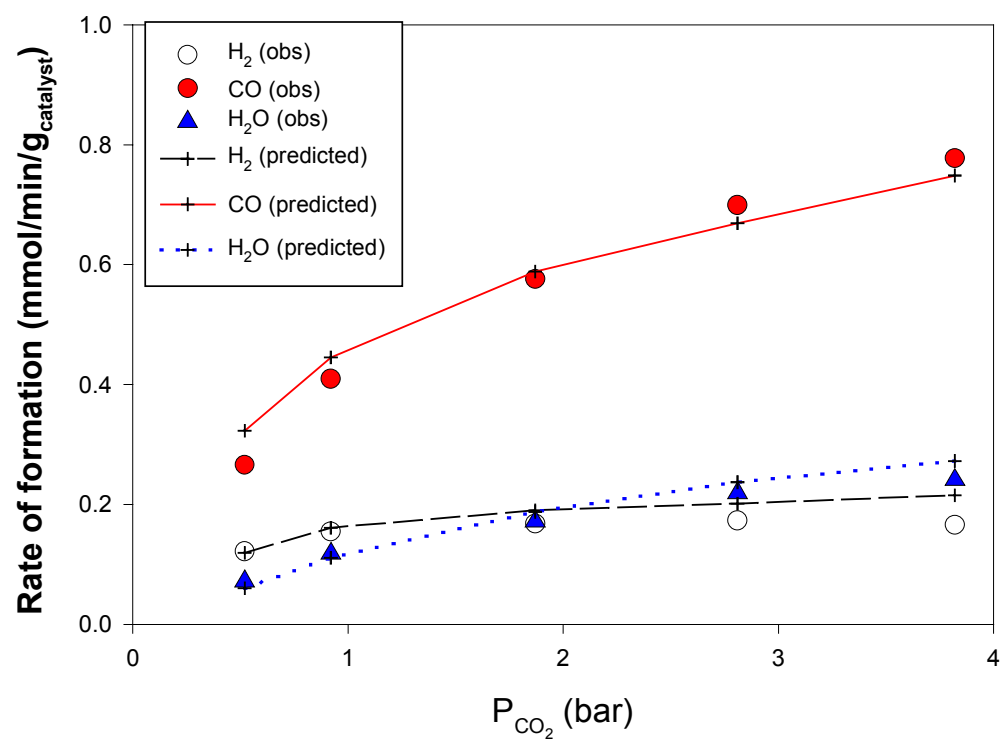

(a) Effect of $\mathbf{P}_{\mathrm{CO} 2}\left(\mathbf{P}_{\mathrm{CH} 4}=1\right.$ bar $)$

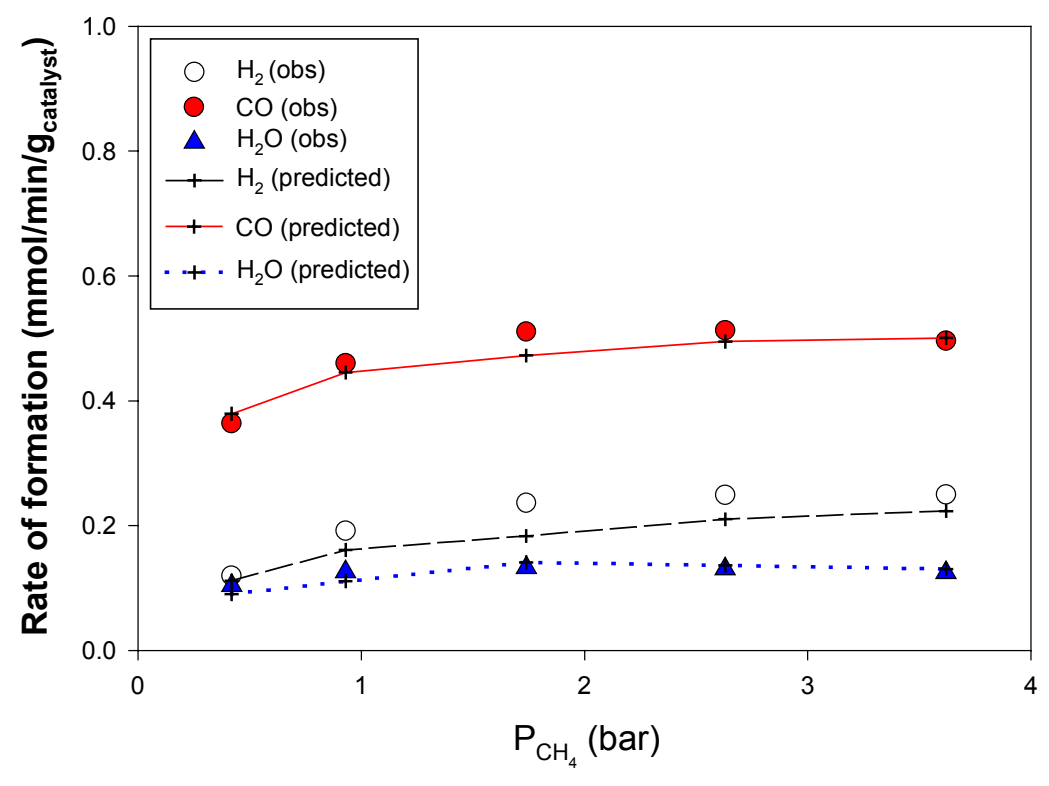

(b) Effect of $\mathrm{P}_{\mathrm{CH} 4}\left(\mathrm{P}_{\mathrm{CO} 2}=1\right.$ bar $)$

Figure 6.1 Effect of reactant partial pressures on the rates of formation of different reaction species for the $\mathrm{CO}_{2}$ reforming of $\mathrm{CH}_{4}$ with $\mathrm{Co}_{6} \mathrm{~W}_{6} \mathrm{C}$ catalyst $\left(\mathrm{T}=600{ }^{\circ} \mathrm{C}\right.$, Particle size $<38 \mu \mathrm{m}$, Total feed $\mathrm{WHSV}=11,200 \mathrm{scc} / \mathrm{hr} /$ g-catalyst., $P_{\text {total }}=5 \mathrm{~atm}$.) Lines denote the LH model as given in section 6.3.4. 


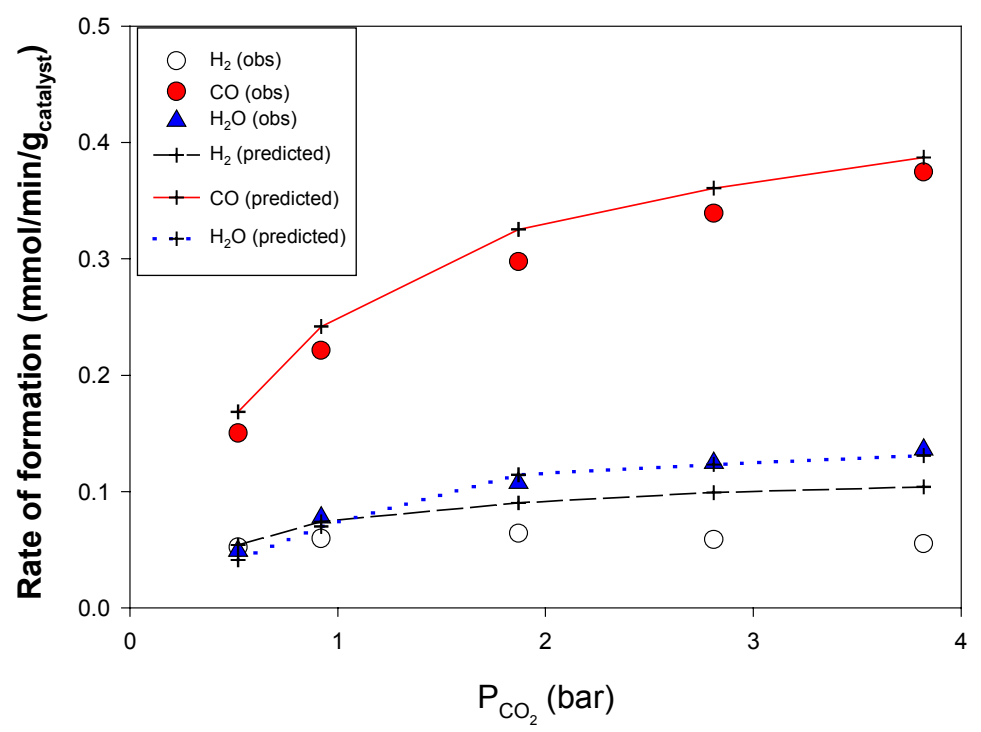

(a) Effect of $\mathbf{P}_{\mathrm{CO} 2}\left(\mathbf{P}_{\mathrm{CH} 4}=1\right.$ bar $)$

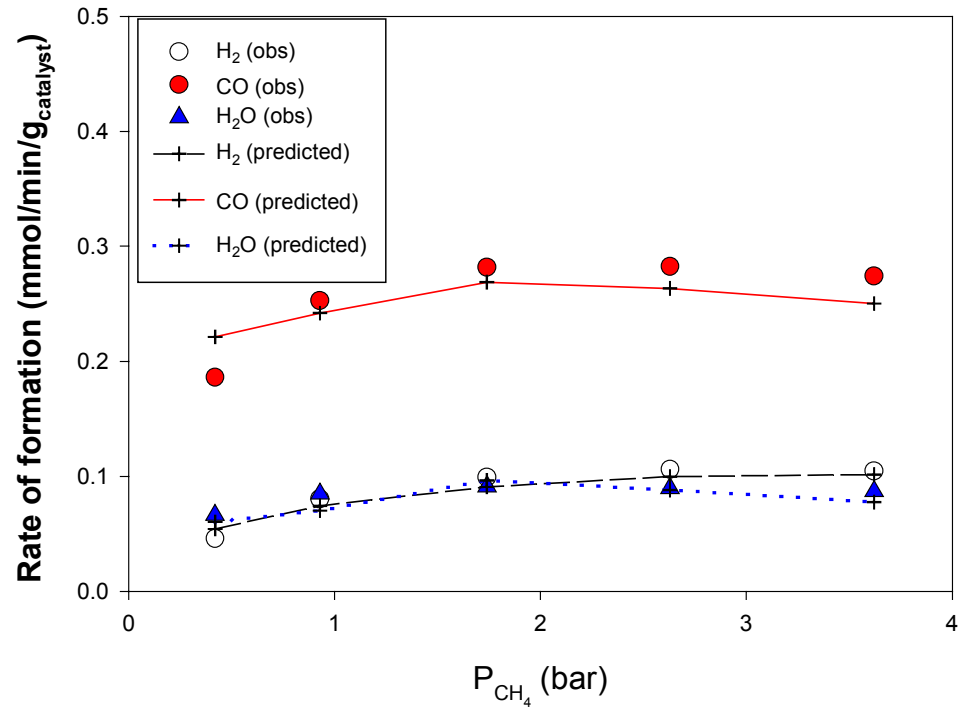

b) Effect of $\mathrm{P}_{\mathrm{CH} 4}\left(\mathrm{P}_{\mathrm{CO} 2}=1\right.$ bar $)$

Figure 6.2 Effect of reactant partial pressures on the rates of formation of different reaction species for the $\mathrm{CO}_{2}$ reforming of $\mathrm{CH}_{4}$ with $\mathrm{Co}_{6} \mathrm{~W}_{6} \mathrm{C}$ catalyst $\left(\mathrm{T}=550{ }^{\circ} \mathrm{C}\right.$, Particle size $<38 \mu \mathrm{m}$, Total feed WHSV $=11,200 \mathrm{scc} / \mathrm{hr} /$ g-catalyst., $P_{\text {total }}=5 \mathrm{~atm}$.) Lines denote the $\mathrm{LH}$ model as given in section 6.3.4. 


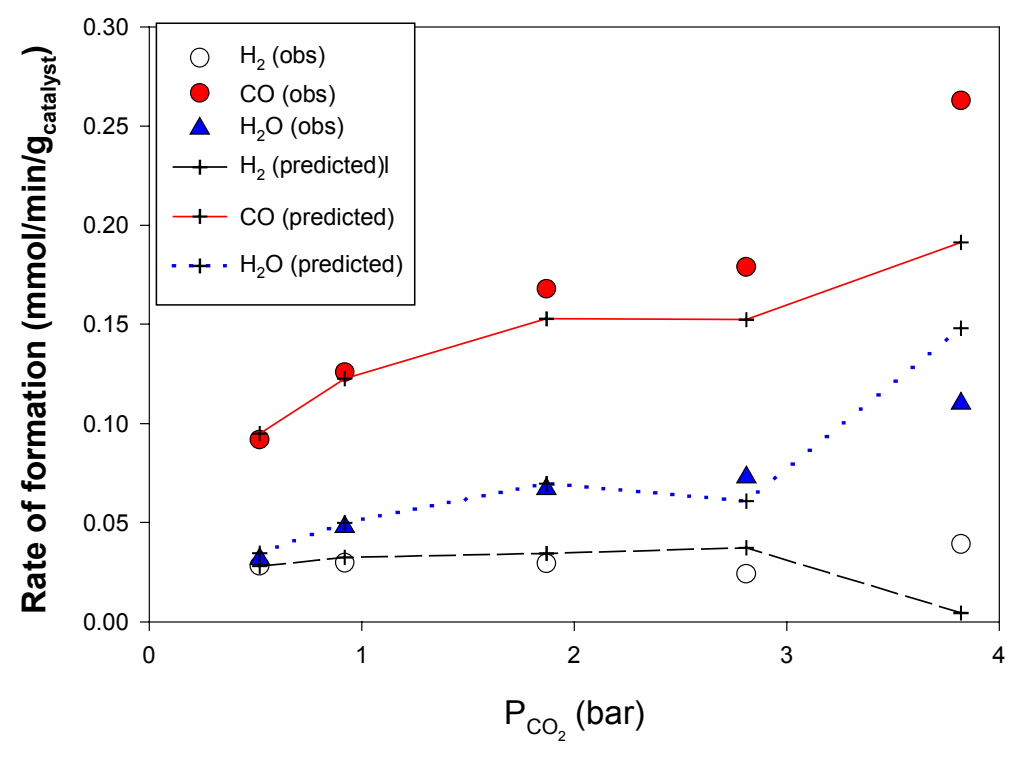

(a) Effect of $\mathrm{P}_{\mathrm{CO} 2}\left(\mathrm{P}_{\mathrm{CH} 4}=1\right.$ bar $)$

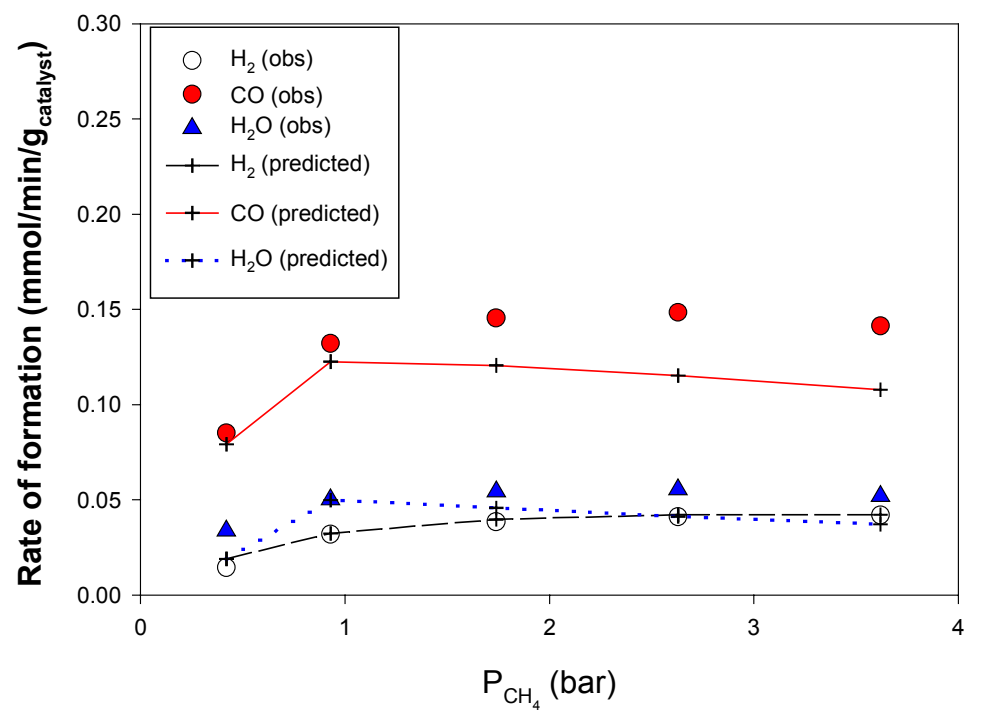

b) Effect of $\mathrm{P}_{\mathrm{CH} 4}\left(\mathrm{P}_{\mathrm{CO} 2}=1\right.$ bar $)$

Figure 6.3 Effect of reactant partial pressures on the rates of formation of different reaction species for the $\mathrm{CO}_{2}$ reforming of $\mathrm{CH}_{4}$ with $\mathrm{Co}_{6} \mathrm{~W}_{6} \mathrm{C}$ catalyst $\left(\mathrm{T}=500{ }^{\circ} \mathrm{C}\right.$, Particle size $<38 \mu \mathrm{m}$, Total feed $\mathrm{WHSV}=11,200 \mathrm{scc} / \mathrm{hr} / \mathrm{g}$-catalyst., $\mathrm{P}_{\text {total }}=5 \mathrm{~atm}$.) Lines denote the LH model as given in section 6.3.4. 


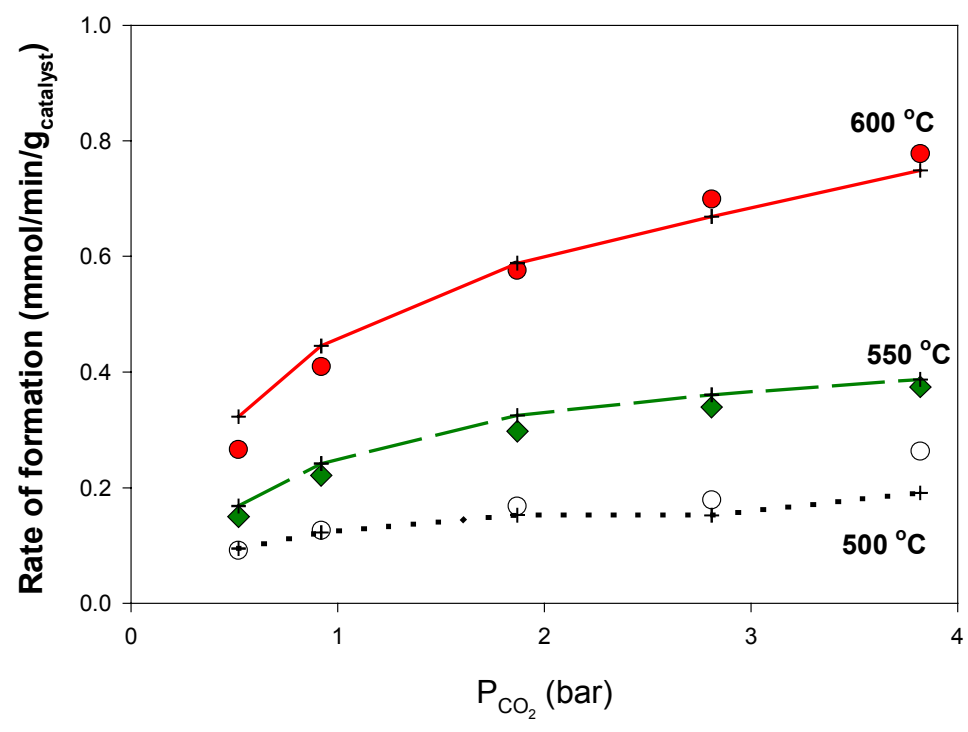

(a) Effect of $\mathrm{P}_{\mathrm{CO} 2}\left(\mathrm{P}_{\mathrm{CH} 4}=1\right.$ bar $)$

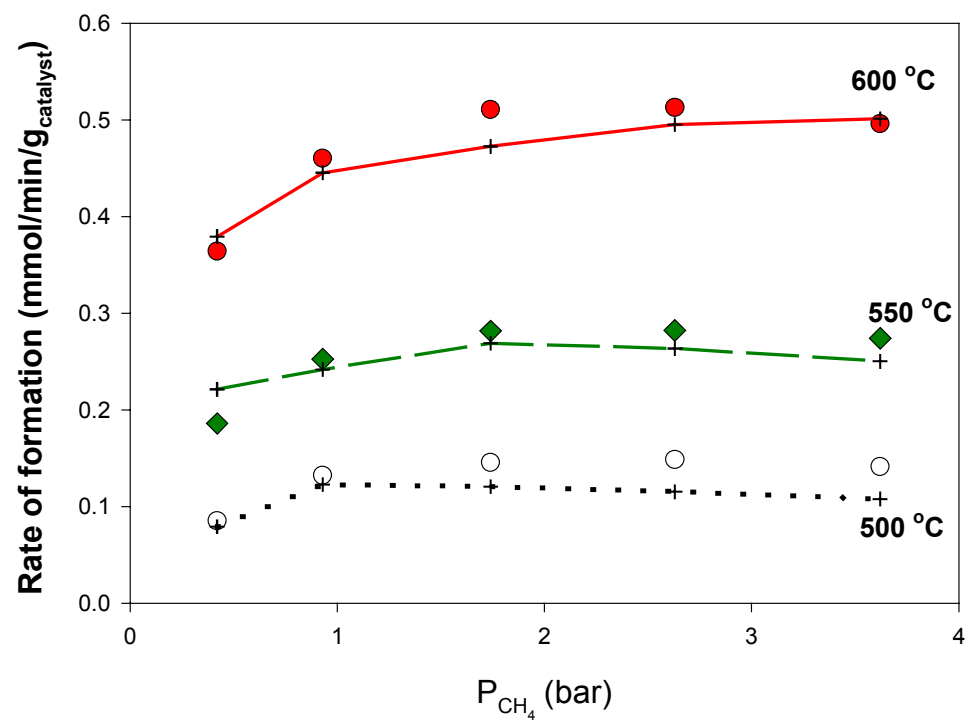

b) Effect of $\mathbf{P}_{\mathrm{CH} 4}\left(\mathbf{P}_{\mathrm{CO} 2}=1\right.$ bar $)$

Figure 6.4 Effect of reaction temperatures and reactant partial pressures on the rates of formation of $\mathrm{CO}$ for the $\mathrm{CO}_{2}$ reforming of $\mathrm{CH}_{4}$ with $\mathrm{Co}_{6} \mathrm{~W}_{6} \mathrm{C}$ catalyst (Particle size $<38 \mu \mathrm{m}$, Total feed WHSV $=11,200 \mathrm{scc} / \mathrm{hr} /$ g-catalyst., $P_{\text {total }}=5 \mathrm{~atm}$.) Lines denote the $\mathrm{LH}$ model as given in section 6.3.4. 


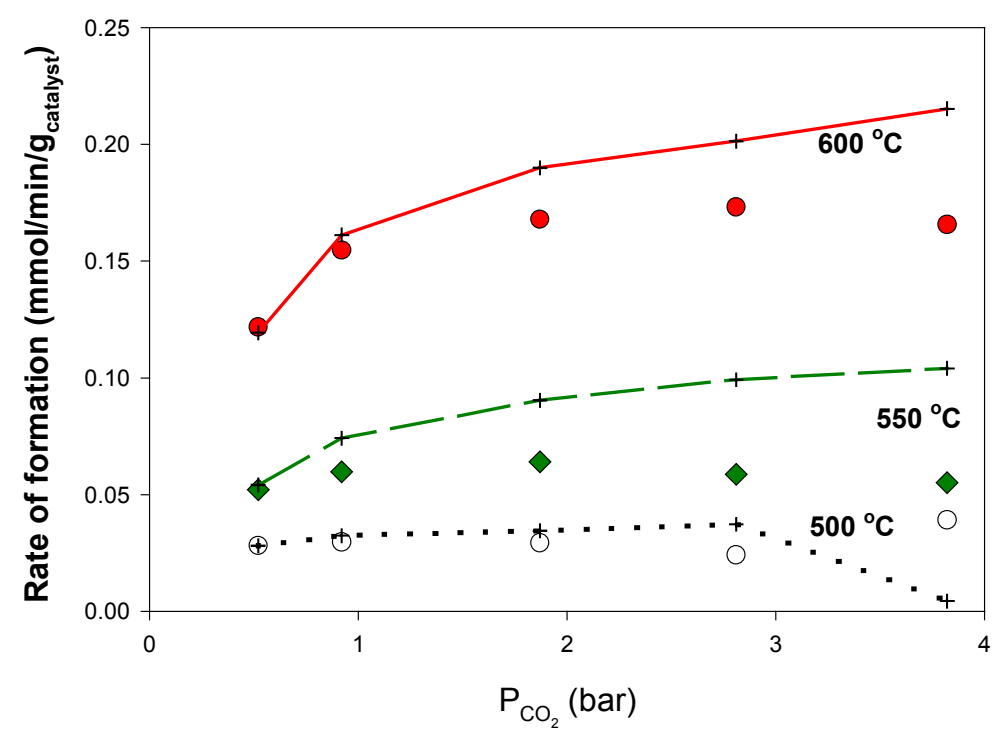

(a) Effect of $\mathrm{P}_{\mathrm{CO} 2}\left(\mathrm{P}_{\mathrm{CH} 4}=1\right.$ bar $)$

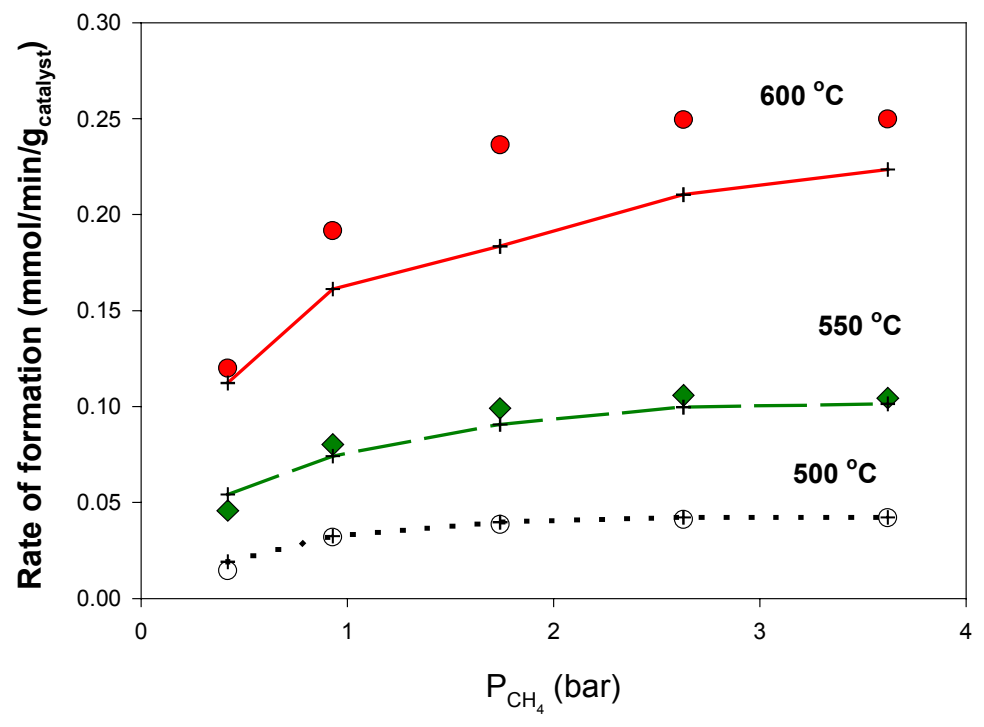

b) Effect of $\mathbf{P}_{\mathrm{CH} 4}\left(\mathrm{P}_{\mathrm{CO} 2}=1\right.$ bar $)$

Figure 6.5 Effect of reaction temperatures and reactant partial pressures on the rates of formation of $\mathrm{H}_{2}$ for the $\mathrm{CO}_{2}$ reforming of $\mathrm{CH}_{4}$ with $\mathrm{Co}_{6} \mathrm{~W}_{6} \mathrm{C}$ catalyst (Particle size $<38 \mu \mathrm{m}$, Total feed $\mathrm{WHSV}=11,200 \mathrm{scc} / \mathrm{hr} /$ g-catalyst., $P_{\text {total }}=5 \mathrm{~atm}$.) Lines denote the LH model as given in section 6.3.4. 


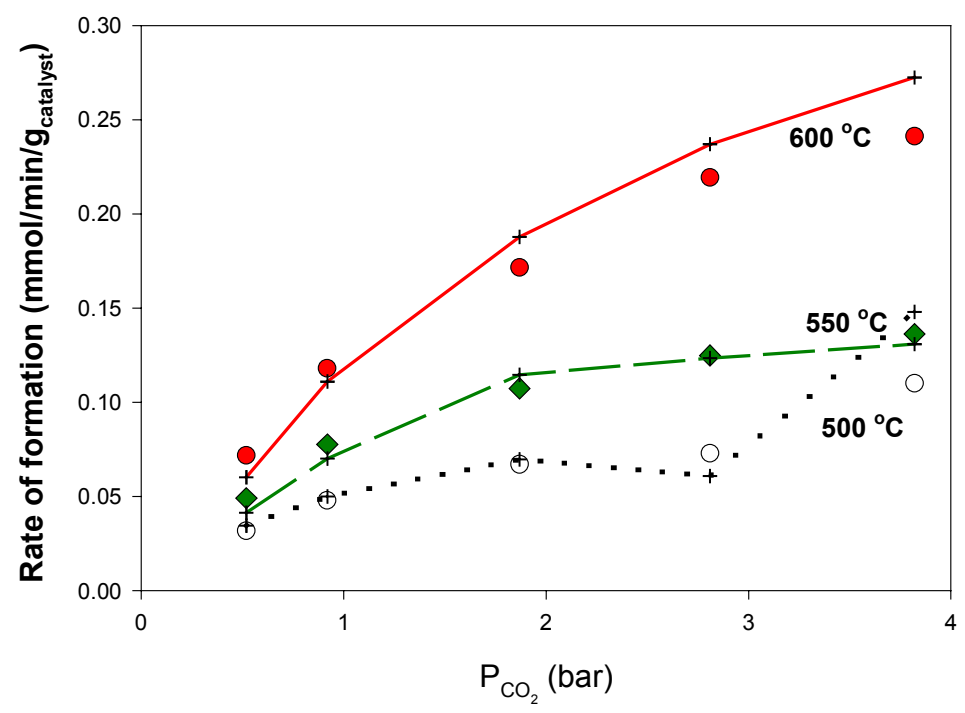

(a) Effect of $\mathrm{P}_{\mathrm{CO} 2}\left(\mathrm{P}_{\mathrm{CH} 4}=1\right.$ bar $)$

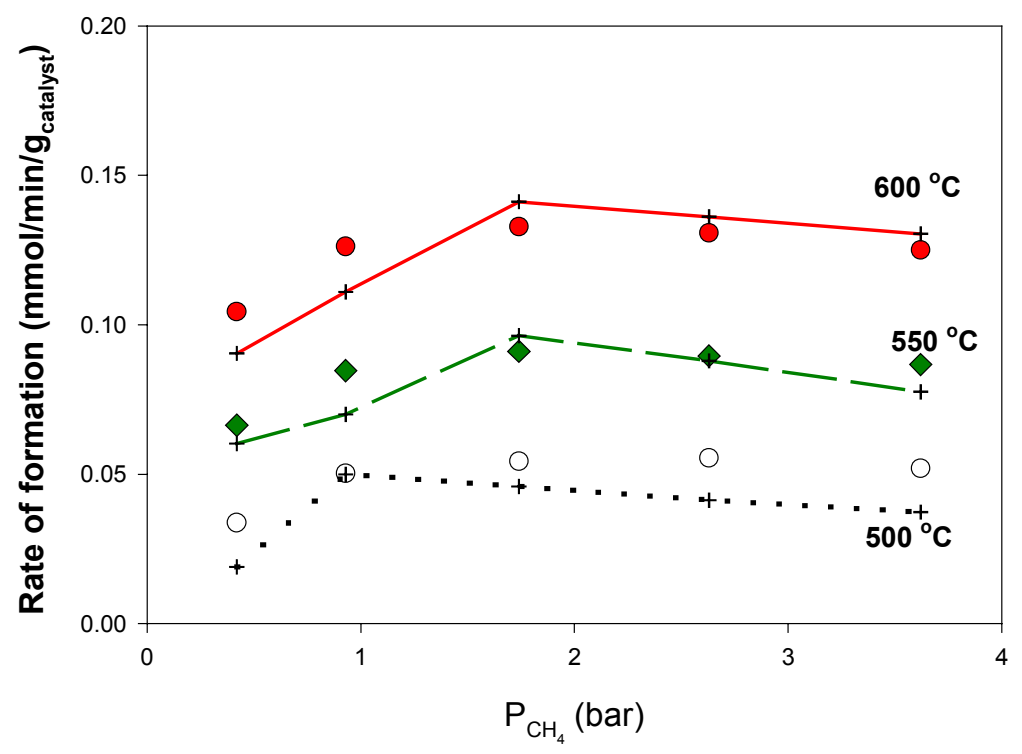

b) Effect of $\mathrm{P}_{\mathrm{CH} 4}\left(\mathrm{P}_{\mathrm{CO} 2}=1\right.$ bar $)$

Figure 6.6 Effect of reaction temperatures and reactant partial pressures on the rates of formation of $\mathrm{H}_{2} \mathrm{O}$ for the $\mathrm{CO}_{2}$ reforming of $\mathrm{CH}_{4}$ with $\mathrm{Co}_{6} \mathrm{~W}_{6} \mathrm{C}$ catalyst (Particle size $<38 \mu \mathrm{m}$, Total feed $\mathrm{WHSV}=11,200 \mathrm{scc} / \mathrm{hr} /$ g-catalyst., $P_{\text {total }}=5 \mathrm{~atm}$.) Lines denote the LH model as given in section 6.3.4. 


\subsubsection{Reaction schemes and thermodynamic analysis}

We have seen in Section 2.5.4 that the entire methane reforming reaction system consists of a complex network of parallel reactions. However, not all the reactions, from this complex set of parallel reactions, are required to depict the whole reaction network. Only a few stoichiometrically independent reactions would suffice to describe the reaction system. The reaction scheme considered in our study is as follows:

$$
\begin{aligned}
\mathrm{CH}_{4}+\mathrm{CO}_{2} & \longrightarrow 2 \mathrm{CO}+2 \mathrm{H}_{2} \quad[\text { Methane Reforming (MR)] } \\
\mathrm{CO}_{2}+\mathrm{H}_{2} & \longrightarrow \mathrm{H}_{2} \mathrm{O}+\mathrm{CO} \quad \text { (RWGS) } \\
\mathrm{CH}_{4} & \longrightarrow 2 \mathrm{H}_{2}+\mathrm{C} \quad[\text { Carbon Deposition (CD)] } \\
\mathrm{CO}_{2}+\mathrm{C} & \longrightarrow 2 \mathrm{CO} \quad[\text { Reverse Boudouard (RB)] }
\end{aligned}
$$

The Methane Reforming (MR) reaction (eq. 6.1) is the main reaction occurring in the system. The Reverse Water Gas Shift (RWGS) reaction (eq. 6.2) is the significant side reaction occurring in the system. This reaction is generally found to be in equilibrium (see, for example, Bradford and Vannice, 1998; Kroll et al., 1998). However, in this study, the reaction was taken to be reversible, as a more general case. The Carbon Deposition (CD) reaction (eq. 6.3) is the decomposition of methane to lay down carbon. In the Reverse Boudouard (RB) reaction (eq. 6.4), the carbon accumulated is gasified by reaction with $\mathrm{CO}_{2}$ to give $\mathrm{CO}$.

Figures 6.7 (a) through (d) compare values of the equilibrium constant $K_{a}$, for a temperature range of $500-850{ }^{\circ} \mathrm{C}$, with the values of the partial pressure ratios for the reactions MR, RWGS, CD and RB, respectively. The equilibrium constant, $\mathrm{K}_{\mathrm{a}}$, is 
obtained as a function of temperature from the software CHEMEQ.BAS developed by Sandler (1989). The details of the calculations of the partial-pressure ratios from the data for every run are tabulated in Appendix F. The ratio of the partial pressures is found to be considerably less than the thermodynamic equilibrium constant at every temperature. Hence, the reaction scheme considered in the study is valid and the reactions were not in equilibrium.

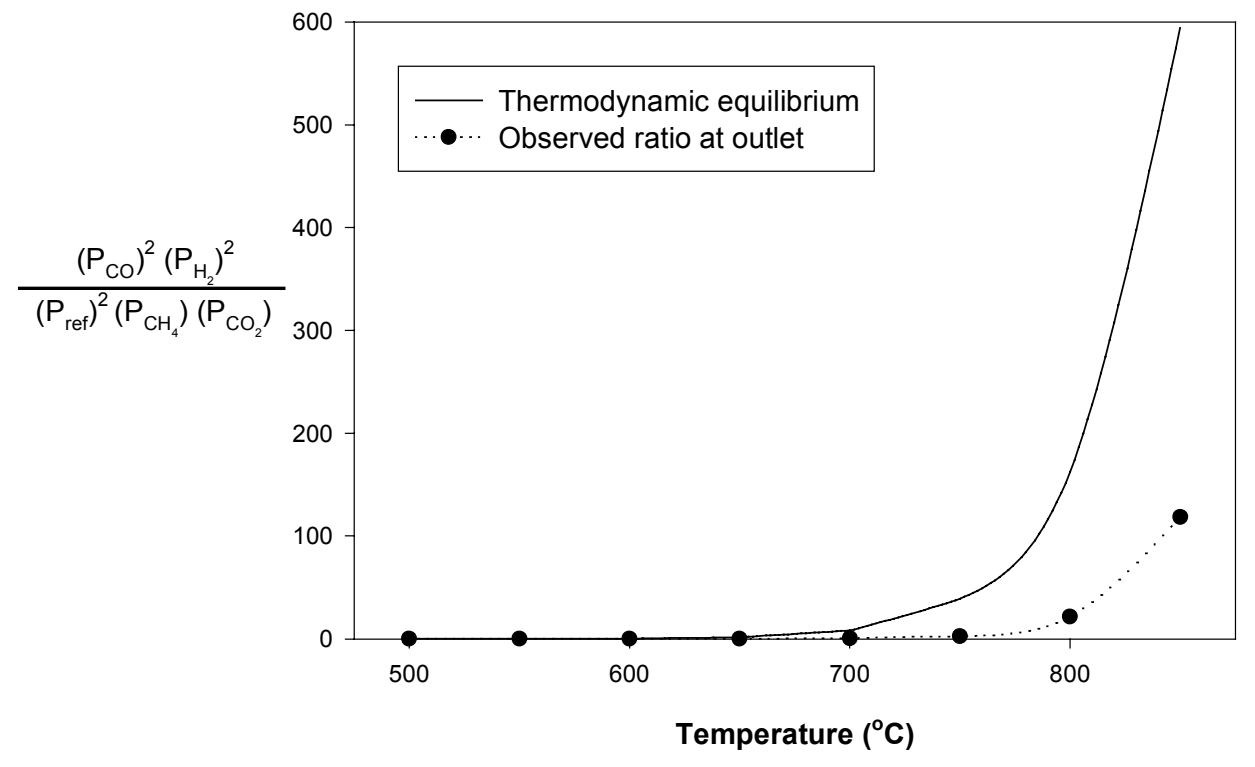

(a) Methane dry reforming (eq. 6.1)

Figure 6.7 Extent of reaction equilibrium as a function of temperature for the $\mathrm{CO}_{2}$ reforming of $\mathrm{CH}_{4}$ with $\mathrm{Co}_{6} \mathrm{~W}_{6} \mathrm{C}$ catalyst (Particle size $<38 \mu \mathrm{m}, \mathrm{CH}_{4} / \mathrm{CO}_{2} / \mathrm{Ar}=1 / 1 / 3$, $P_{\text {total }}=5$ atm, $P_{\text {ref }}=1$ atm). 


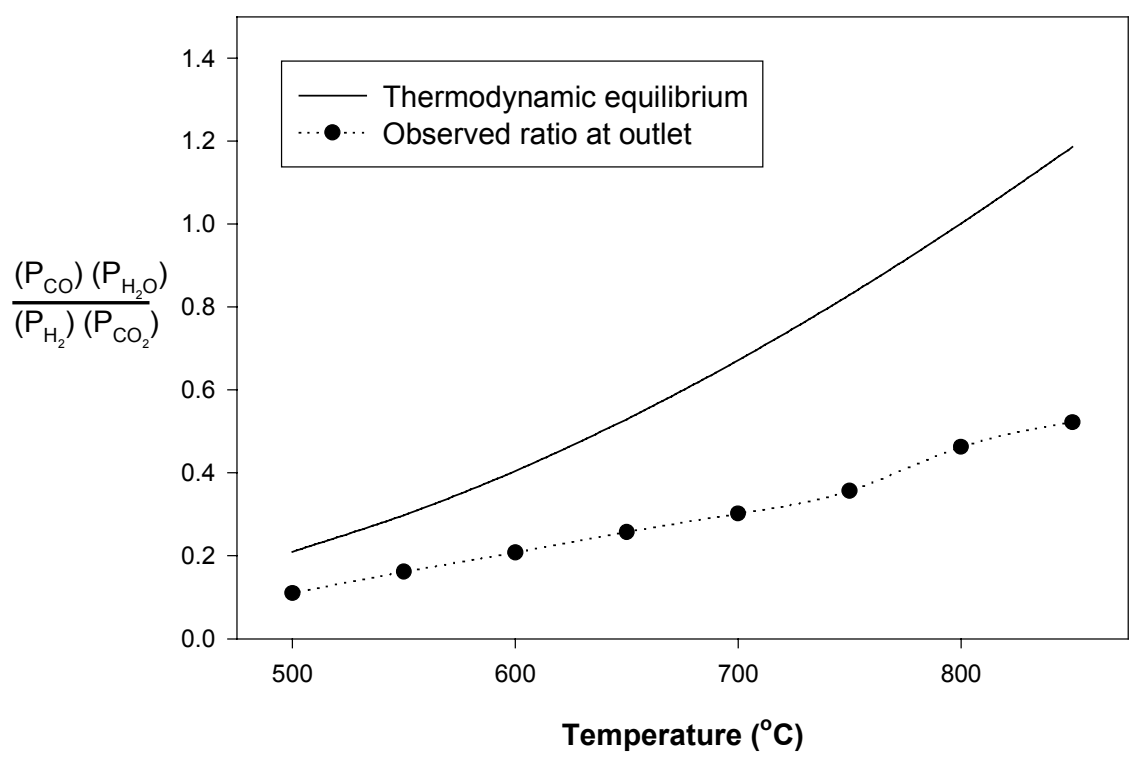

(b) RWGS (eq. 6.2)

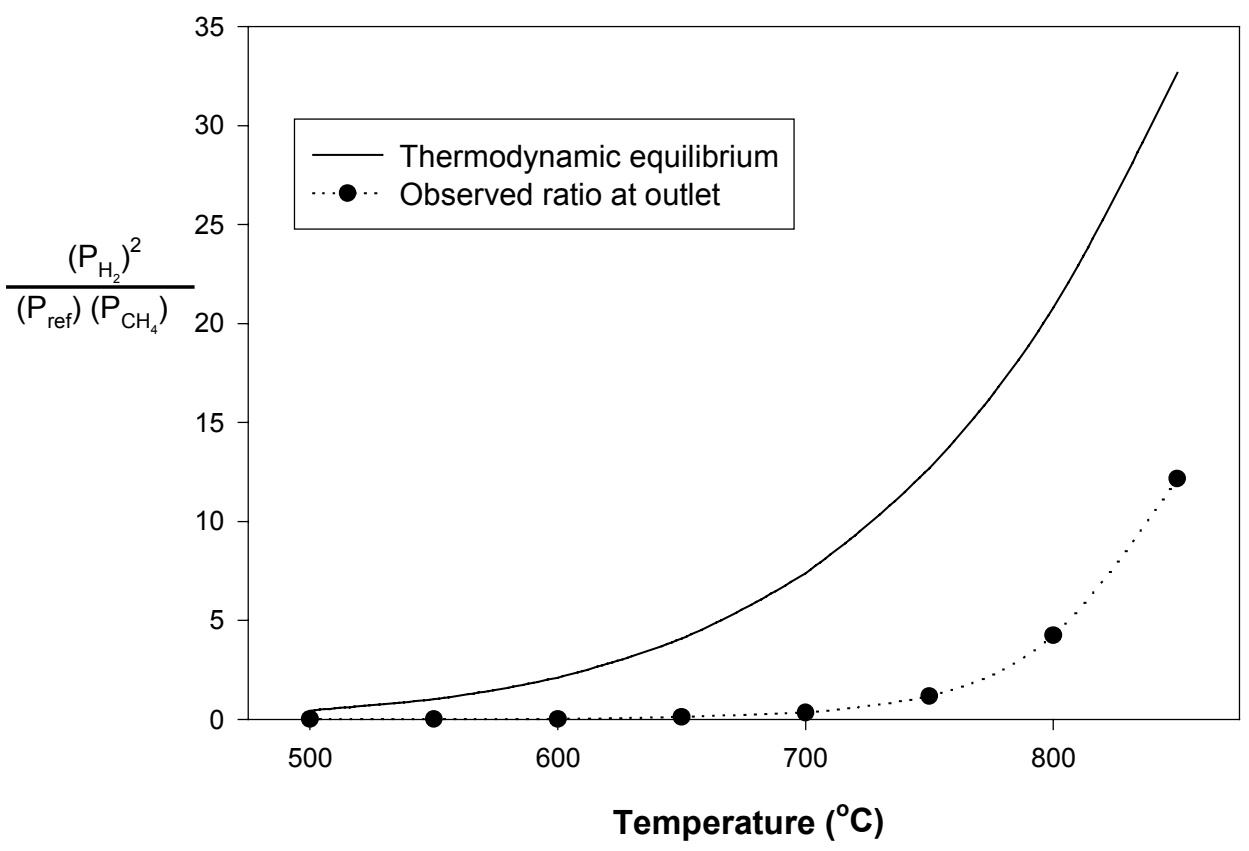

(c) Carbon deposition (eq. 6.3)

Figure 6.7 Continued 


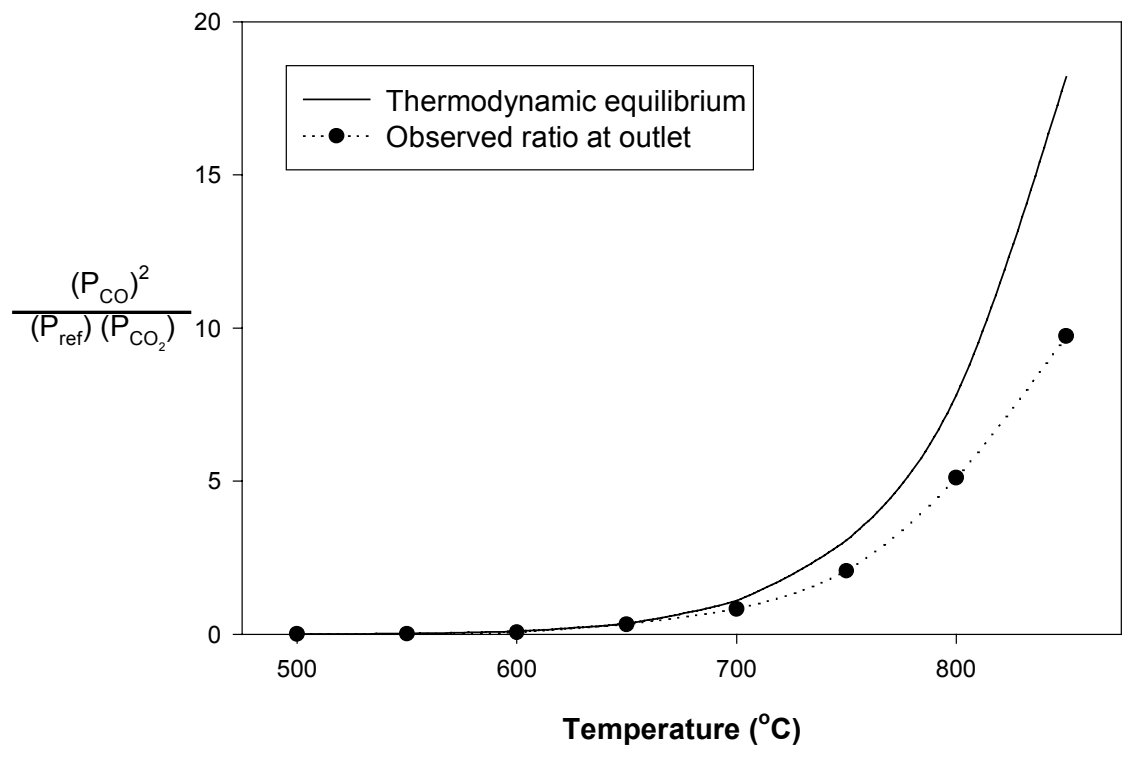

(d) Reverse Boudouart reaction (eq. 6.4)

Figure 6.7 Continued

\subsubsection{Power Law Model}

A simple power law model for the rates of formation of each of the products $\left(\mathrm{H}_{2}\right.$, $\mathrm{CO}$ and $\mathrm{H}_{2} \mathrm{O}$ ) was proposed. The model is given as follows:

$\mathbf{r}=\mathbf{k}\left[\mathbf{P}_{\mathrm{CH} 4}\right]^{\mathrm{m}}\left[\mathbf{P}_{\mathrm{CO} 2}\right]^{\mathrm{n}}$

where,

$\mathrm{r}=$ rate of formation of $\mathrm{H}_{2}, \mathrm{CO}$ or $\mathrm{H}_{2} \mathrm{O}$

$\mathrm{k}=$ reaction rate constant

$\mathrm{m}, \mathrm{n}=$ power law coefficients

$\mathrm{P}_{\mathrm{CH} 4}, \mathrm{P}_{\mathrm{CO} 2}=$ partial pressures of $\mathrm{CH}_{4}, \mathrm{CO}_{2}$

The rate constant, $\mathrm{k}$ can be further expressed in the Arrhenius form as: 
$k=k_{0} \exp [-E a /(R T)]$

where,

$\mathrm{k}_{0}=$ pre-exponential factor

$\mathrm{Ea}=$ apparent activation energy

$\mathrm{R}=$ universal gas constant

$\mathrm{T}=$ reaction temperature

The values of these parameters with the coefficient of determination $\left(\mathrm{R}^{2}\right)$, obtained for the entire set of experiments are tabulated as follows:

Table 6.4. Parameter estimates of the Power Law model

\begin{tabular}{|c|c|c|c|c|c|}
\hline $\begin{array}{c}\text { Reaction } \\
\text { Species }\end{array}$ & $\begin{array}{c}\mathbf{k}_{\mathbf{0}} \\
\left.\text { (mol/min//gcat/atm }^{(\mathbf{m}+\mathbf{n})}\right)\end{array}$ & $\begin{array}{c}\mathbf{E}_{\mathbf{a}} \\
(\mathbf{k c a l} / \mathbf{m o l})\end{array}$ & $\mathbf{m}$ & $\mathbf{n}$ & $\mathbf{R}^{\mathbf{2}}$ \\
\hline $\mathrm{H}_{2}$ & 509.2 & 25.86 & 0.39 & 0.06 & 0.97 \\
\hline $\mathrm{CO}$ & 21.67 & 18.6 & 0.17 & 0.43 & 0.98 \\
\hline $\mathrm{H}_{2} \mathrm{O}$ & 0.3981 & 13.86 & 0.11 & 0.50 & 0.97 \\
\hline
\end{tabular}

A comparison of the observed (experimental) rates of formation of each of the species $\mathrm{H}_{2}, \mathrm{CO}$ and $\mathrm{H}_{2} \mathrm{O}$ with those predicted by the power-law model is given in Figures 6.8 - 6.13. The data includes the entire set of experiments as given in Table 6.1. Figures $6.8-6.10$ give the comparison plot for increasing reactant partial pressures and temperatures. The curves denote the rates predicted by the power-law model, while the plotted points denote the experimental data. The model seems to fit the observed data quite well. Besides, the apparent activation energy (Ea) obtained for each of the species $\mathrm{H}_{2}, \mathrm{CO}$ and $\mathrm{H}_{2} \mathrm{O}$ is comparable to those obtained from the Arrhenius plots (Table 5.2) for the initial catalyst activity, as seen earlier. 


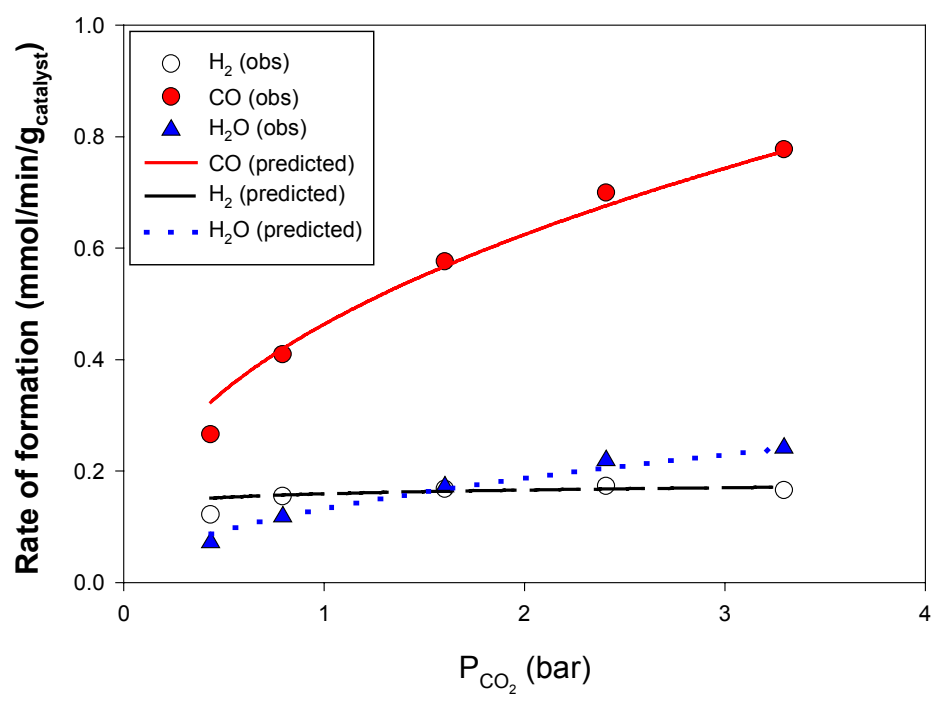

(a) Effect of $\mathbf{P}_{\mathrm{CO} 2}\left(\mathbf{P}_{\mathrm{CH} 4}=1\right.$ bar $)$

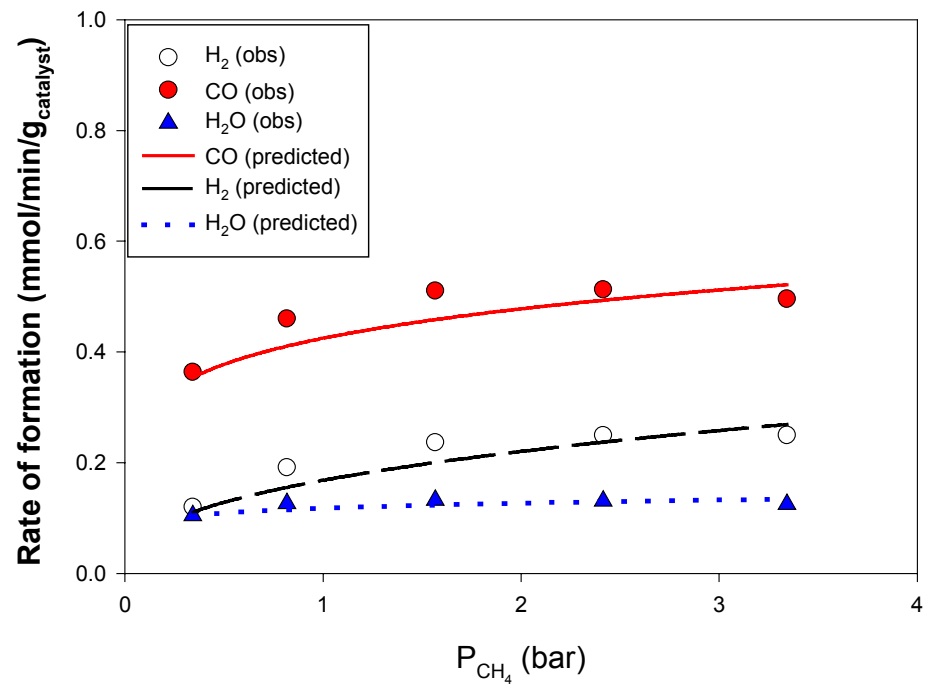

b) Effect of $\mathbf{P}_{\mathrm{CH} 4}\left(\mathbf{P}_{\mathrm{CO} 2}=1\right.$ bar $)$

Figure 6.8 Comparison of predicted and observed rates of formation of different reaction species for increasing reactant partial pressures during $\mathrm{CH}_{4} / \mathrm{CO}_{2}$ reforming with $\mathrm{Co}_{6} \mathrm{~W}_{6} \mathrm{C}$ catalyst. $\left(\mathrm{T}=600{ }^{\circ} \mathrm{C}\right.$, Particle size $<38 \mu \mathrm{m}$, Total feed $\mathrm{WHSV}=11,200 \mathrm{scc} / \mathrm{hr} / \mathrm{g}$-catalyst., $P_{\text {total }}=5 \mathrm{~atm}$.) Lines denote the power-law model. 


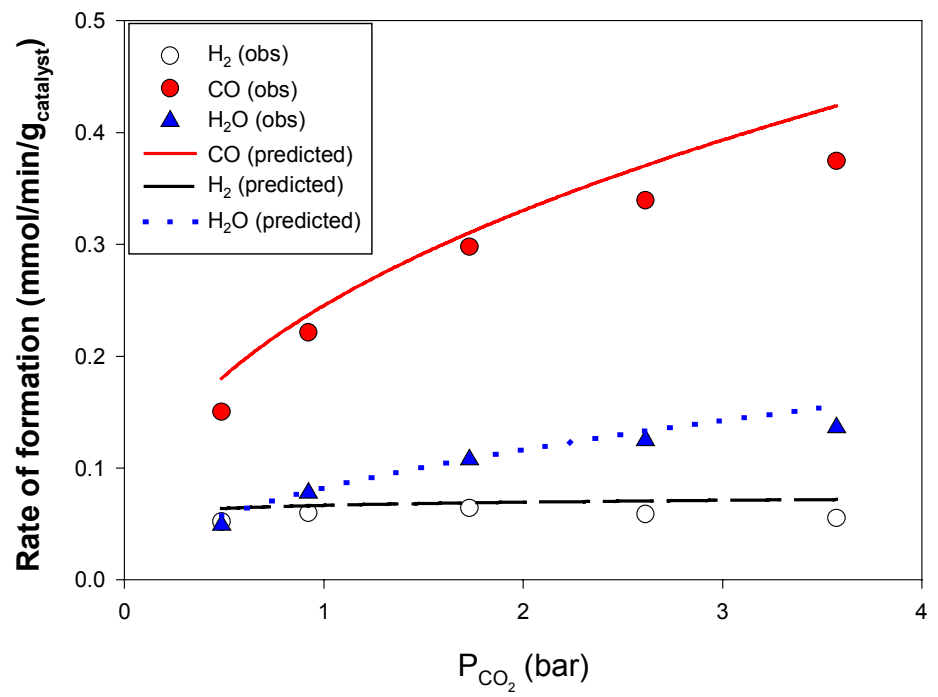

(a) Effect of $\mathrm{P}_{\mathrm{CO} 2}\left(\mathrm{P}_{\mathrm{CH} 4}=1\right.$ bar $)$

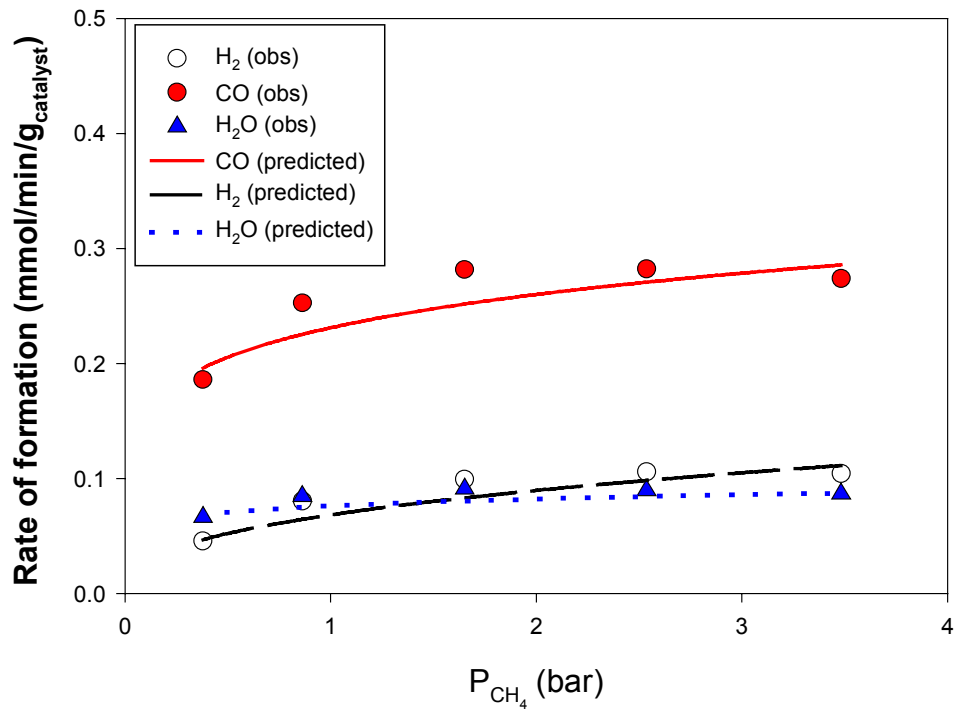

b) Effect of $\mathrm{P}_{\mathrm{CH} 4}\left(\mathrm{P}_{\mathrm{CO} 2}=1\right.$ bar $)$

Figure 6.9 Comparison of predicted and observed rates of formation of different reaction species for increasing reactant partial pressures during $\mathrm{CH}_{4} / \mathrm{CO}_{2}$ reforming with $\mathrm{Co}_{6} \mathrm{~W}_{6} \mathrm{C}$ catalyst. $\left(\mathrm{T}=550{ }^{\circ} \mathrm{C}\right.$, Particle size $<38 \mu \mathrm{m}$, Total feed $\mathrm{WHSV}=11,200 \mathrm{scc} / \mathrm{hr} / \mathrm{g}$-catalyst., $P_{\text {total }}=5 \mathrm{~atm}$.) Lines denote the power-law model. 


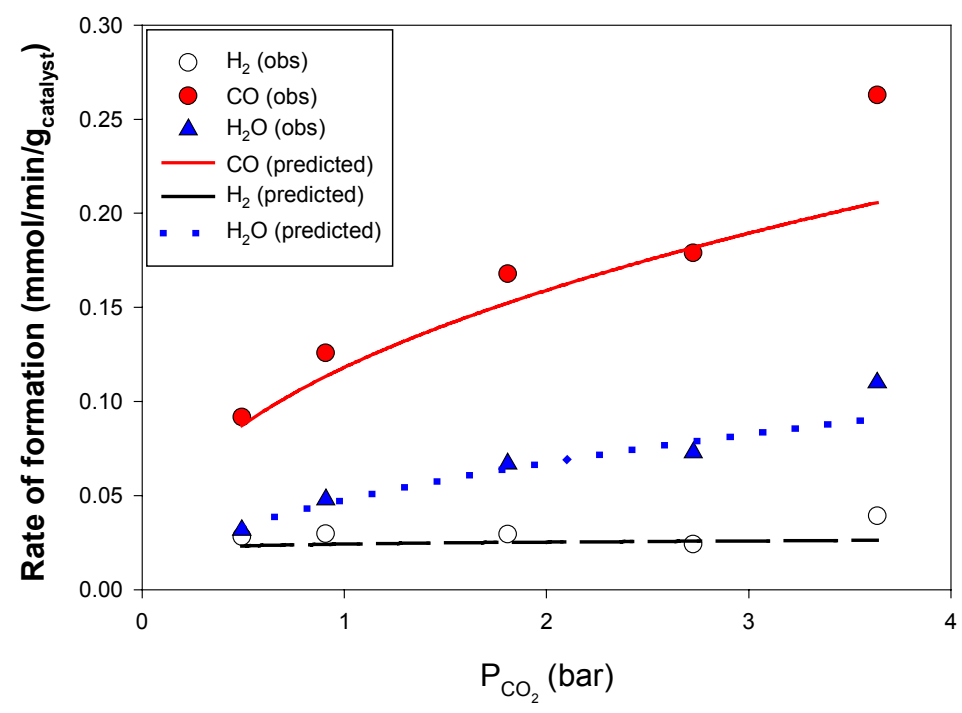

(a) Effect of $\mathbf{P}_{\mathrm{CO} 2}\left(\mathbf{P}_{\mathrm{CH} 4}=1\right.$ bar $)$

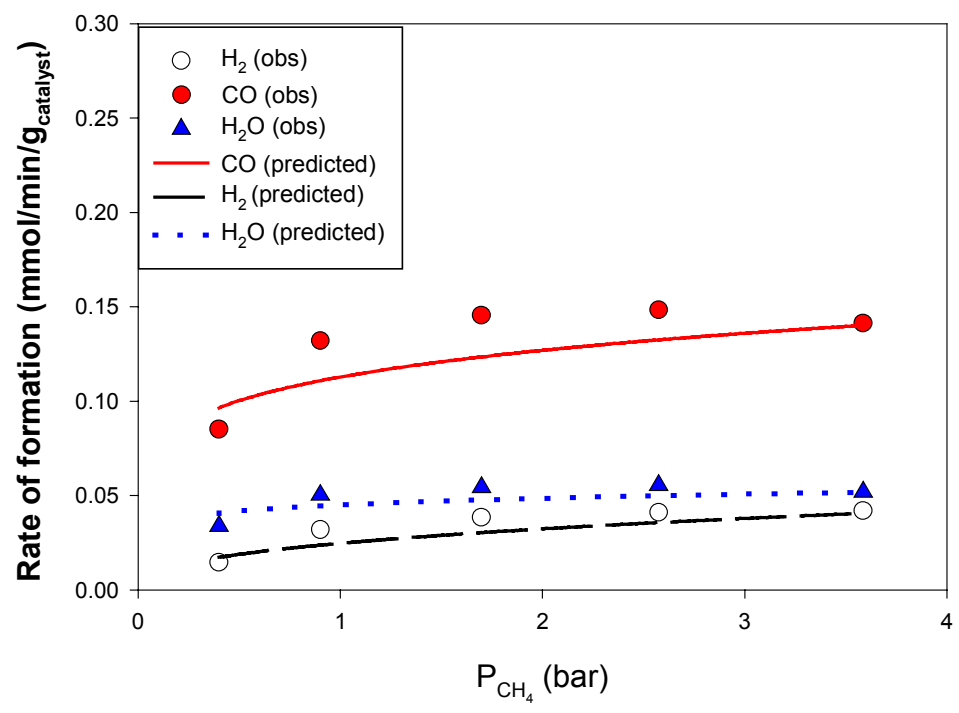

b) Effect of $\mathrm{P}_{\mathrm{CH} 4}\left(\mathrm{P}_{\mathrm{CO} 2}=1\right.$ bar $)$

Figure 6.10 Comparison of predicted and observed rates of formation of different reaction species for increasing reactant partial pressures during $\mathrm{CH}_{4} / \mathrm{CO}_{2}$ reforming with $\mathrm{Co}_{6} \mathrm{~W}_{6} \mathrm{C}$ catalyst. $\left(\mathrm{T}=500{ }^{\circ} \mathrm{C}\right.$, Particle size $<38 \mu \mathrm{m}$, Total feed $\mathrm{WHSV}=11,200 \mathrm{scc} / \mathrm{hr} / \mathrm{g}$-catalyst., $P_{\text {total }}=5 \mathrm{~atm}$.) Lines denote the power-law model. 


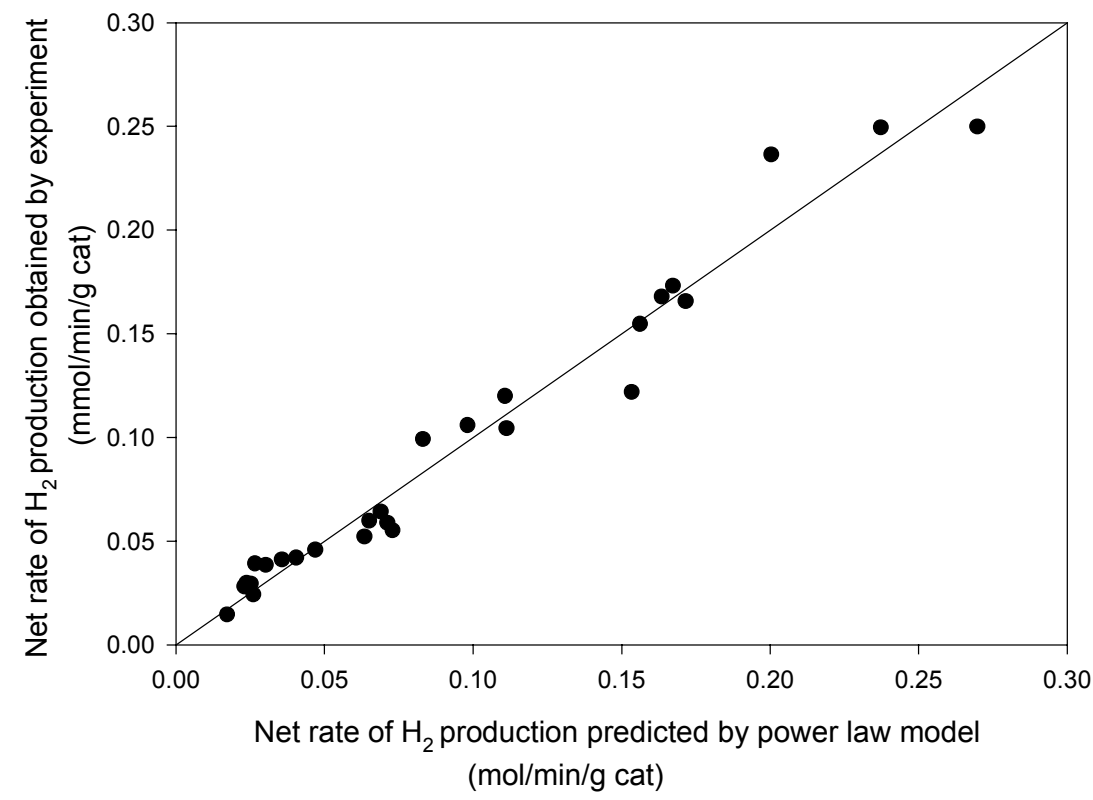

Figure 6.11 Comparison plot for the net rates of $\mathrm{H}_{2}$ formation

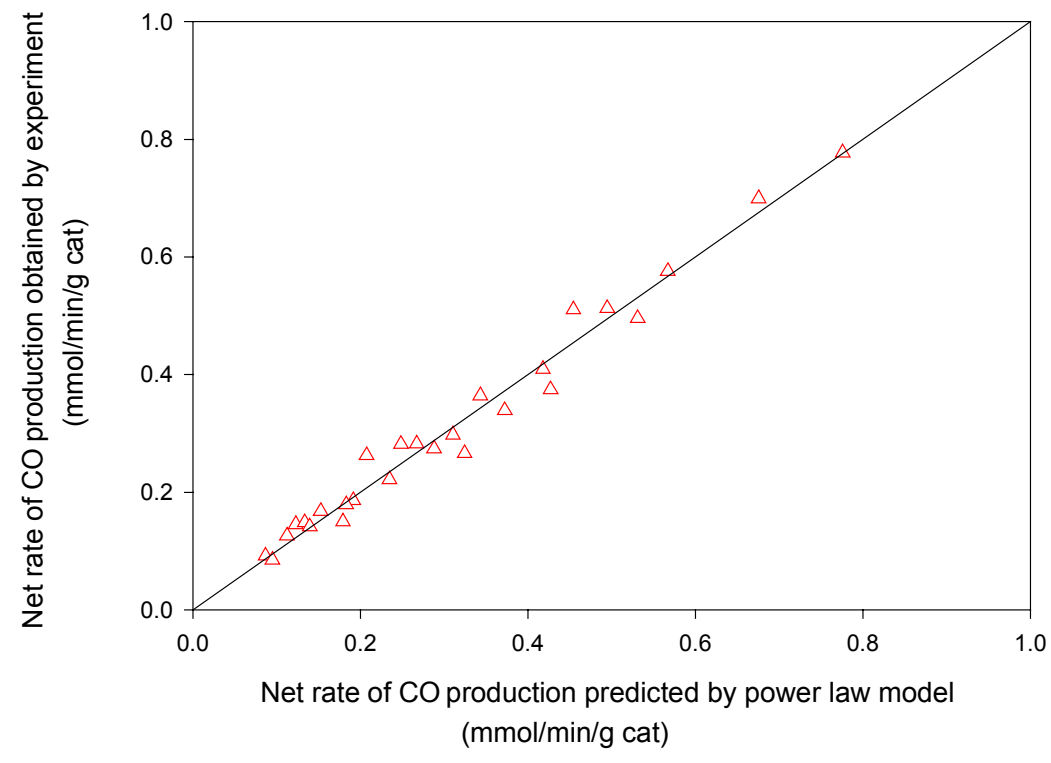

Figure 6.12 Comparison plot for the net rates of CO formation 


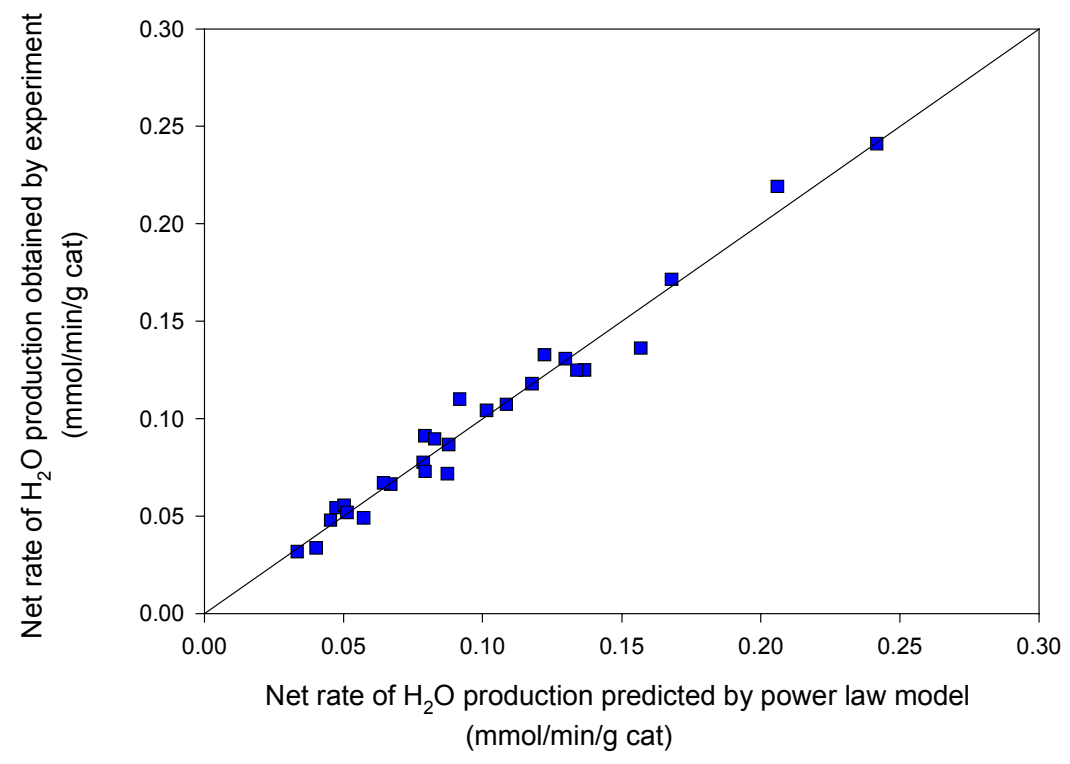

Figure 6.13 Comparison plot for the net rates of $\mathrm{H}_{2} \mathrm{O}$ formation

However, the power law model is insufficient to comprehend the various reaction steps and mechanisms taking place on the catalyst surface. Hence, after a thorough understanding of the various reactions steps occurring in our system, a LangmuirHinshelwood type of reaction model has been proposed which incorporates the various mechanistic aspects of the reforming reaction. 


\subsubsection{Langmuir Hinshelwood (LH) Model}

In this study, the experimental data for the rates of product formation were found to be more reliable and sensitive to small conversions for the differential operating conditions, as compared to the rate of consumption of the products. Hence, the entire focus is directed towards the modeling of rates of production of $\mathrm{CO}, \mathrm{H}_{2}$ and $\mathrm{H}_{2} \mathrm{O}$. We have seen in Chapter 2 the various possible reaction mechanisms and adsorption-based kinetic models for the $\mathrm{CO}_{2}$ reforming of $\mathrm{CH}_{4}$. Based on these, the following simple reaction mechanism is proposed.

$$
\begin{aligned}
& \mathbf{C H}_{4}+* \stackrel{\mathbf{K}_{1}}{\longrightarrow} \mathbf{C H}_{\mathbf{X}} *+(\mathbf{x} / 2) \mathbf{H}_{2} \\
& \mathrm{CO}_{2}+* \stackrel{\mathrm{K}_{2}}{\longrightarrow} \mathrm{CO}+\mathrm{O} * \\
& \mathrm{CH}_{\mathrm{X}} *+\mathrm{O} * \stackrel{\mathrm{k}_{3}}{\longrightarrow} \mathrm{CO}+(\mathrm{x} / 2) \mathrm{H}_{2}+2 * \\
& \mathrm{CH}_{\mathrm{X}} * \stackrel{\mathrm{K}_{4}}{\rightleftharpoons} \mathrm{C} *+(\mathrm{x} / 2) \mathrm{H}_{2} \\
& \mathrm{H}_{2}+\mathrm{O} * \stackrel{\mathbf{k}_{\mathbf{5}}}{\stackrel{\mathrm{k}-\mathbf{5}}{\longrightarrow}} \mathrm{H}_{\mathbf{2}} \mathrm{O}+* \\
& \mathrm{C} *+\mathrm{O} * \stackrel{\mathrm{k}_{6}}{\longrightarrow} \mathrm{CO}+2 *
\end{aligned}
$$

The parameter $\mathrm{x}$ is assumed to equal a value of 2 for the sake of simplicity. Further, most of these steps can be expressed as a series of simpler steps, as seen earlier in Section 
2.5.3. However, this would increase the number of parameters involved. To simplify the mathematical modeling, the detailed steps are not considered in this reaction sequence.

The first step in the kinetic model (eq. 6.7) represents the dissociative adsorption of methane to give the surface $\mathrm{CH}_{\mathrm{X}}$ fragment and $\mathrm{H}_{2}$ is immediately released in the gas phase. This step is assumed to be in equilibrium. The adsorption of $\mathrm{CH}_{4}$ on the active site, the subsequent dissociation to $\mathrm{CH}_{\mathrm{X}}$ species and adsorbed $\mathrm{H}$ atoms, followed by the combination of $\mathrm{H}$ atoms to release $\mathrm{H}_{2}$ in the gas phase, form the detailed sequence of steps that are not considered in the model.

The second step (eq. 6.8) is the dissociative adsorption of $\mathrm{CO}_{2}$ on a free site, leaving behind adsorbed oxygen and producing gaseous CO. This step is also considered to be in equilibrium. The initial adsorption of $\mathrm{CO}_{2}$ on an active site, decomposition to surface oxygen and surface $\mathrm{CO}$, followed by release of the surface $\mathrm{CO}$ to gas phase form the detailed steps that are not shown.

The third step (eq. 6.9) is the slow, irreversible step between the surface $\mathrm{CH}_{\mathrm{X}}$ species and adsorbed oxygen atoms to release $\mathrm{CO}$ and $\mathrm{H}_{2}$ in the gas phase. However, the intermediate steps reported in the literature (Luo et al., 2000; Osaki et al., 1998; Bradford and Vannice, 1998) consist of the formation of a $\mathrm{CH}_{\mathrm{X}} \mathrm{O}$ species, which then dissociates to adsorbed $\mathrm{CO}$ and surface $\mathrm{H}$ atoms. These adsorbed species in turn release $\mathrm{CO}$ and $\mathrm{H}_{2}$ in the gas phase.

The fourth step (eq. 6.10) gives the decomposition of the adsorbed $\mathrm{CH}_{\mathrm{X}}$ species to give surface carbon, releasing gaseous $\mathrm{H}_{2}$. This step is assumed to be in equilibrium, as the net rate of carbon formation is small compared to the rate of formation of other products, as shown earlier. Besides, the rate of carbon formed in the reaction system is 
not measured in our study. Carbon deposition is predominant only at high temperatures (about $850{ }^{\circ} \mathrm{C}$ ) while all the experimental data for kinetic studies lie in the temperature range of $500-600{ }^{\circ} \mathrm{C}$. Hence, the assumption of carbon deposition being in equilibrium is reasonable.

The reaction between adsorbed oxygen and gaseous $\mathrm{H}_{2}$ to produce water in the fifth step (eq. 6.11) is assumed to be reversible but not in equilibrium. The detailed steps consist of the reaction between surface oxygen and adsorbed $\mathrm{H}$ atoms to give $\mathrm{OH}$ species, which further reacts with an additional $\mathrm{H}$ atom to give $\mathrm{H}_{2} \mathrm{O}$.

The sixth step (eq. 6.12) is the slow irreversible surface reaction between adsorbed oxygen and surface carbon to yield gaseous $\mathrm{CO}$. This reaction step signifies the removal of accumulated carbon from the reaction system as described earlier. This is observed in the experimental data, which occurs in the low temperature regime.

The reaction scheme considered in Section 6.3.2 (eqs. 6.1-6.4) can be expressed as a simple combination of the various steps of the reaction mechanism proposed above. MR (eq. 6.1) can be expressed as a combination of the first three steps (eqs. 6.7, 6.8 and 6.9). The overall methane reforming reaction is irreversible as the eq. (6.9) is irreversible. RWGS (eq. 6.2) can be expressed as a combination of eqs. (6.8) and (6.11). RWGS is reversible but is not in equilibrium, as governed by eq. (6.11). The $\mathrm{CD}$ reaction (eq. 6.3) can be shown to be a combination of eqs. (6.7) and (6.10). $\mathrm{CD}$ is in equilibrium, as both the steps (eqs. 6.7 and 6.10) are in equilibrium. The RB reaction (eq. 6.4), can be expressed as a combination of eqs. (6.8) and (6.12). RB is irreversible as eq. (6.12) is rate determining and irreversible. 
From the above reaction mechanism, the expressions for the rate of formation of the products can be readily derived and are given as follows:

$$
\begin{aligned}
& r_{\mathrm{CO}}=\frac{K_{1} K_{2}}{(\text { den })^{2}}\left(\frac{P_{\mathrm{CH}_{4}} P_{\mathrm{CO}_{2}}}{P_{\mathrm{CO}} P_{\mathrm{H}_{2}}}\right)\left(k_{3}+\frac{k_{6} K_{4}}{P_{\mathrm{H}_{2}}}\right) \\
& r_{\mathrm{H}_{2}}=\frac{k_{3} K_{1} K_{2}}{(\text { den })^{2}}\left(\frac{P_{\mathrm{CH}_{4}} P_{\mathrm{CO}_{2}}}{P_{\mathrm{CO}} P_{\mathrm{H}_{2}}}\right)-\frac{k_{5} K_{2}}{(\text { den })}\left(\frac{P_{\mathrm{H}_{2}} P_{\mathrm{CO}_{2}}}{P_{\mathrm{CO}}}\right)+\frac{k_{-5} P_{\mathrm{H}_{2} \mathrm{O}}}{(\text { den })} \\
& r_{\mathrm{H}_{2} \mathrm{O}}=\frac{k_{5} K_{2}}{(\text { den })}\left(\frac{P_{\mathrm{H}_{2}} P_{\mathrm{CO}_{2}}}{P_{\mathrm{CO}}}\right)-\frac{k_{-5} P_{\mathrm{H}_{2} \mathrm{O}}}{(\text { den })}
\end{aligned}
$$

where:

$$
\text { den }=1+K_{1}\left(\frac{P_{\mathrm{CH}_{4}}}{P_{\mathrm{H}_{2}}}\right)+K_{2}\left(\frac{P_{\mathrm{CO}_{2}}}{P_{\mathrm{CO}}}\right)+K_{1} K_{4}\left(\frac{P_{\mathrm{CH}_{4}}}{P_{\mathrm{H}_{2}}^{2}}\right)
$$

The detailed derivation of the model is given in Appendix G.

\subsubsection{Parameter estimation for the LH model}

All the experiments were performed in the differential mode and the rates of formation of each of the products $\mathrm{H}_{2}, \mathrm{CO}$ and $\mathrm{H}_{2} \mathrm{O}$ are tabulated in Table 6.3. The details of the calculations of these observed experimental rates are given in Appendix E. The model parameters $\mathrm{k}_{3}, \mathrm{k}_{6}, \mathrm{k}_{5}, \mathrm{k}_{-5}, \mathrm{~K}_{1}, \mathrm{~K}_{2}$ and $\mathrm{K}_{4}$ were calculated using non-linear leastsquares analysis employed for parameter estimation using the Marquardt-Levenberg algorithm. Estimation of the parameters was based on the minimization of the sum of 
residual squares of the observed experimental reaction rates and the predicted rates for each species obtained from eqs. $6.13-6.15$.

The initial steps of the parameter estimation consisted of determining the parameters from each of the three equations (eqs. 6.13-6.15) at every temperature. Eq. 6.13 was first solved for the parameters $\mathrm{k}_{3}, \mathrm{k}_{6}, \mathrm{~K}_{1}, \mathrm{~K}_{2}$ and $\mathrm{K}_{4}$ at $600{ }^{\circ} \mathrm{C}$. Using these values in eq. 6.14 , the values of the remaining constants $\mathrm{k}_{5}$ and $\mathrm{k}_{-5}$ at $600{ }^{\circ} \mathrm{C}$ were obtained. Then the values of all the parameters obtained were used as the initial guess in eq. 6.15 and the solution converges to a slightly different value. These new values of the parameters now served as the initial guess and the procedure was again repeated for eqs. $6.13,6.14$ and 6.15 in turn. After a few cycles, the values of the parameters obtained served as the initial guess for the simultaneous solution of all the three non-linear equations (eqs. 6.13-6.15) at $600{ }^{\circ} \mathrm{C}$. Now the entire procedure was repeated again for obtaining the values of the parameters at $550{ }^{\circ} \mathrm{C}$ and subsequently at $500{ }^{\circ} \mathrm{C}$. The values of the parameters obtained at $600{ }^{\circ} \mathrm{C}$ were used as the starting initial guess for the estimation at $550{ }^{\circ} \mathrm{C}$ and similarly the values estimated at $550{ }^{\circ} \mathrm{C}$ were used for the parameter estimation at $500{ }^{\circ} \mathrm{C}$.

After obtaining the values of all the parameters at 500, 550 and $600{ }^{\circ} \mathrm{C}$, the parameters were related at all temperatures by the Arrhenius and van't Hoff equations as follows:

$$
\begin{aligned}
& k_{i}=A_{i} \exp \left[-E a_{i} /(R T)\right] \\
& K_{i}=A\left(K_{i}\right) \exp \left[-\Delta H a_{i} /(R T)\right]
\end{aligned}
$$

where:

$\mathrm{k}_{\mathrm{i}}=$ rate constant 
$\mathrm{K}_{\mathrm{i}}=$ adsorption coefficient

$\mathrm{Ea}_{\mathrm{i}}=$ apparent activation energy

$\Delta \mathrm{Ha}_{\mathrm{i}}=$ apparent adsorption enthalpy

$\mathrm{A}_{\mathrm{i},} \mathrm{A}\left(\mathrm{K}_{\mathrm{i}}\right)=$ pre-exponential factors

$\mathrm{R}=$ universal gas constant

$\mathrm{T}=$ reaction temperature

The values of the apparent activation energies, the apparent adsorption enthalpies and the corresponding pre-exponential factors were calculated from the values of the parameters obtained earlier at 500,550 and $600{ }^{\circ} \mathrm{C}$. These values now served as the initial guess for the subsequent iterations of all the observed experimental data with the three non-linear eqs. $6.13-6.15$ at all reaction temperatures. The only modification to the above rate equations was the substitution of eq. 6.17 and 6.18 to give the temperature dependence of the rate constants and the adsorption coefficients. Thus a set of 81 data points (the rates of formation of $\mathrm{H}_{2}, \mathrm{CO}$ and $\mathrm{H}_{2} \mathrm{O}$ for all the partial pressures at all the reaction temperatures) were considered for the final estimation. The parameters were successfully estimated considering all the experimental data and are tabulated in Table 6.5 below. The coefficient of determination $\left(\mathrm{R}^{2}\right)$ of the final estimated parameters is:

$$
\mathrm{R}^{2}=0.978
$$

A comparison of the experimental data with the predicted values from the $\mathrm{LH}$ model for all the product species is given in Figure 6.14. Figures 6.15-6.17 give the comparison plots for each of the species $\left(\mathrm{H}_{2}, \mathrm{CO}\right.$ and $\left.\mathrm{H}_{2} \mathrm{O}\right)$. Figures $6.1-6.6$ give the 
comparison of the reaction rates predicted by the LH model with those of the observed experimental data, for increasing reactant partial pressure and reaction temperatures. The LH model is used for predicting value for every corresponding experimental data-point. The symbols denote the experimental data and the predicted points are represented by $(+)$ which are joined by straight lines. The model gives a reasonably good fit to the observed experimental data.

Whenever any adsorption constant is determined for experimental data, it has to satisfy certain thermodynamic rules (Lee, 1985; Vannice et al. 1979). However, the values of $\Delta \mathrm{Ha}_{\mathrm{i}}$ obtained for all the parameters (Table 6.5) do not necessarily satisfy all the set of these rules. This can be attributed to the fact that the adsorption equilibrium proposed in this model is not necessarily the true adsorption equilibrium of a single species. As seen earlier, each step (eqs. 6.7-6.12) actually consists of a number of detailed sequential steps that are avoided for the ease of mathematical modeling. Hence, $\Delta \mathrm{Ha}_{\mathrm{i}}$ represents an apparent, and not the true, adsorption enthalpy. The values of parameter estimates obtained are not necessarily the only solution to the model equations, due to the non-linearity in the parameters estimated. Therefore, this model can be regarded as an effective learning step in understanding the various steps of the dry reforming reaction chemistry. 
Table 6.5 Parameter estimates for the Langmuir Hinshelwood (LH) model

\begin{tabular}{|c|l|l|}
\hline Parameter & \multicolumn{1}{|c|}{ Estimate } & \multicolumn{1}{c|}{ Unit } \\
\hline $\mathrm{A}_{3}$ & $1.5052 \times 10^{11}$ & $\mathrm{~mol} / \mathrm{min} / \mathrm{g}$-cat \\
\hline $\mathrm{Ea}_{3}$ & 38.03 & $\mathrm{kcal} / \mathrm{mol}$ \\
\hline $\mathrm{A}_{6}$ & $1.09 \times 10^{5}$ & $\mathrm{~mol} / \mathrm{min} / \mathrm{g}-\mathrm{cat}$ \\
\hline $\mathrm{Ea}_{6}$ & 30.22 & $\mathrm{kcal} / \mathrm{mol}$ \\
\hline $\mathrm{A}_{5}$ & 0.26 & $\mathrm{~mol} / \mathrm{min} / \mathrm{atm} . / \mathrm{g}-\mathrm{cat}$ \\
\hline $\mathrm{Ea}_{5}$ & 4.58 & $\mathrm{kcal} / \mathrm{mol}$ \\
\hline $\mathrm{A}_{-5}$ & $8.06 \times 10^{4}$ & $\mathrm{~mol} / \mathrm{min} / \mathrm{atm} . / \mathrm{g}-\mathrm{cat}$ \\
\hline $\mathrm{Ea}_{-5}$ & 29.62 & $\mathrm{kcal} / \mathrm{mol}$ \\
\hline $\mathrm{A}_{\left(\mathrm{K}_{1}\right)}$ & $3.4 \times 10^{-6}$ & $\mathrm{dimensionless}$ \\
\hline$\Delta \mathrm{Ha}_{1}$ & -2.46 & $\mathrm{kcal} / \mathrm{mol}$ \\
\hline $\mathrm{A}\left(\mathrm{K}_{2}\right)$ & $1.32 \times 10^{-2}$ & $\mathrm{dimensionless}$ \\
\hline$\Delta \mathrm{Ha}_{2}$ & -3.31 & $\mathrm{kcal} / \mathrm{mol}$ \\
\hline $\mathrm{A}\left(\mathrm{K}_{4}\right)$ & $1.033 \times 10^{11}$ & $\mathrm{~atm}$. \\
\hline$\Delta \mathrm{Ha}_{4}$ & 32.30 & $\mathrm{kcal} / \mathrm{mol}$ \\
\hline & & \\
\hline
\end{tabular}




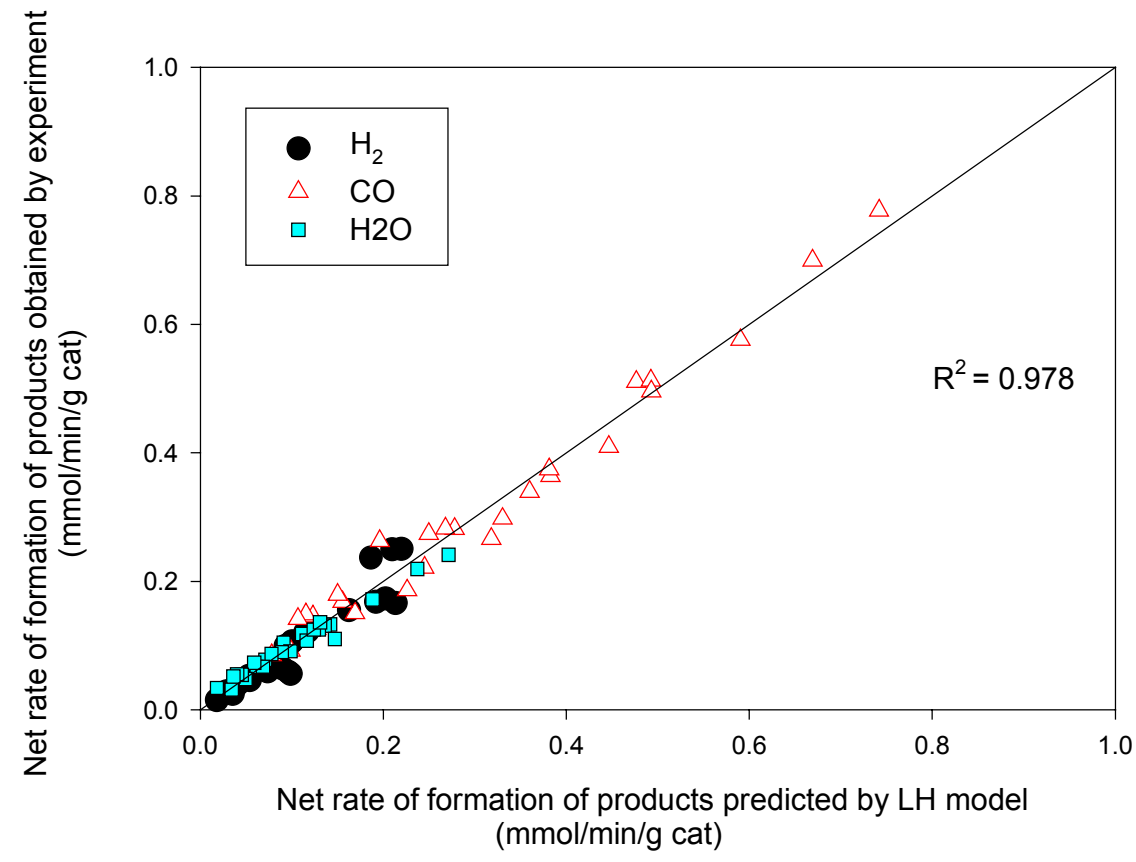

Figure 6.14 Comparison plot for the net rates of formation for each of the species

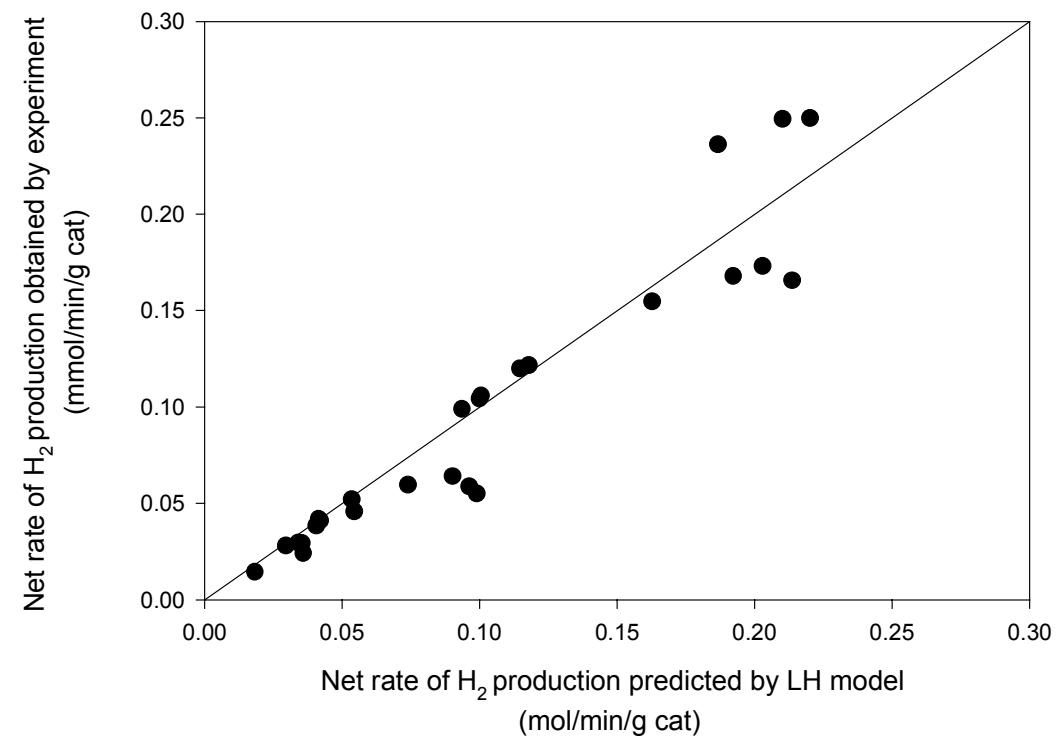

Figure 6.15 Comparison plot for the net rates of $\mathrm{H}_{2}$ formation 


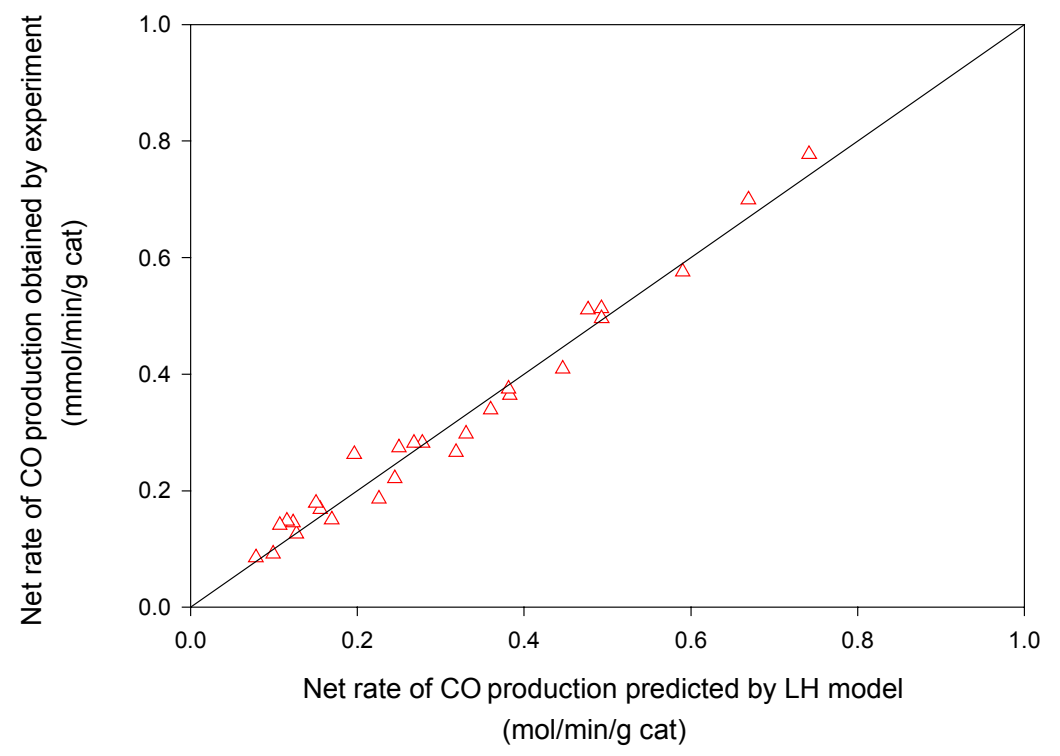

Figure 6.16 Comparison plot for the net rates of $\mathrm{CO}$ formation

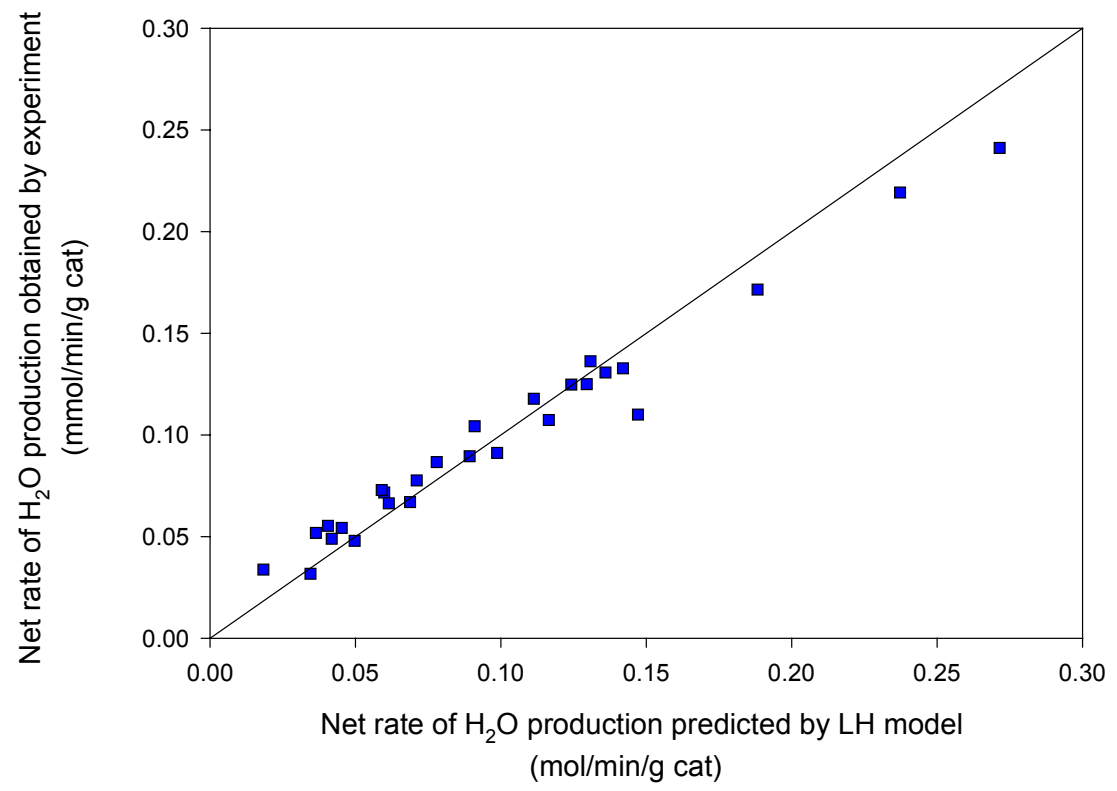

Figure 6.17 Comparison plot for the net rates of $\mathrm{H}_{2} \mathrm{O}$ formation 


\subsection{Summary}

The kinetics of $\mathrm{CO}_{2}$ reforming of methane with $\mathrm{Co}_{6} \mathrm{~W}_{6} \mathrm{C}$ catalyst was studied under differential conditions over a temperature range of $500-600^{\circ} \mathrm{C}$, based on a detailed experimental design. The rates of formation of the products $\mathrm{H}_{2}, \mathrm{CO}$ and $\mathrm{H}_{2} \mathrm{O}$ were used for the kinetic analysis. The observed rates seem to follow a Langmuir-Hinshelwood type of reaction mechanism. The rate of $\mathrm{CO}$ production was always greater than the combined rates of $\mathrm{H}_{2}$ and $\mathrm{H}_{2} \mathrm{O}$ production for all reaction conditions. A simple reaction scheme consisting of four reactions was considered and the thermodynamic analysis showed that the reactions were not in equilibrium.

A simple power-law model for the reforming kinetics was proposed for each of the product species $\left(\mathrm{H}_{2}, \mathrm{CO}\right.$ and $\left.\mathrm{H}_{2} \mathrm{O}\right)$. The model seems to fit the observed data well. However, the model is incapable of incorporating all the mechanistic details involved in the reaction system. Hence, a Langmuir-Hinshelwood type of kinetic model has been proposed based on a simplified reaction mechanism. The mechanism incorporates carbon deposition as well as carbon removal occurring in the reaction system, both of which are generally disregarded in most of the reported kinetic models. The parameters of the model were successfully estimated for all the experimental data. The comparison plots of the observed data and the predicted model show generally a good fit for all the product species. 


\section{CHAPTER 7}

\section{SUMMARY AND RECOMMENDATIONS}

\subsection{Summary}

The dry reforming of methane with carbon dioxide was investigated over supported nickel $\left(\mathrm{Ni} / \mathrm{Al}_{2} \mathrm{O}_{3}\right)$ and platinum $\left(\mathrm{Pt} / \mathrm{ZrO}_{2}\right)$ catalysts [Chapter 4]; and unsupported cobalt tungsten carbide $\left(\mathrm{Co}_{6} \mathrm{~W}_{6} \mathrm{C}\right)$ catalyst [Chapter 5]. A detailed kinetic modeling of $\mathrm{CH}_{4}-\mathrm{CO}_{2}$ reforming with $\mathrm{Co}_{6} \mathrm{~W}_{6} \mathrm{C}$ catalyst is presented subsequently (Chapter 6). Product analysis for all the catalysts showed the formation of carbon monoxide and hydrogen as the major products. However, a considerable amount of water formation was also observed due to the Reverse Water Gas Shift (RWGS) reaction occurring simultaneously. Besides, carbon deposition was observed at high temperatures, which was more significant with the nickel catalyst. Nevertheless, no other side products such as hydrocarbons, oxygenates etc. were evident in the product analysis.

The activity of the commercial $\mathrm{Ni} / \mathrm{Al}_{2} \mathrm{O}_{3}$ catalyst was examined for increasing and decreasing temperature cycles. The reaction temperature cycles seem to stabilize the catalyst activity. The apparent activation energies for all the reaction species were obtained for $450-525{ }^{\circ} \mathrm{C}$ temperature ranges. These values are found to be consistent with the reported values in the literature. The $\mathrm{Pt} / \mathrm{ZrO}_{2}$ catalyst, prepared in-house, was found to be to be deactivating within two hours. This was attributed to the unstable zirconia support. 
When the cobalt tungsten carbide $\left(\mathrm{Co}_{6} \mathrm{~W}_{6} \mathrm{C}\right)$ material was pretreated in a 1:1 feed mixture at $850{ }^{\circ} \mathrm{C}$ and $5 \mathrm{~atm}$, the resulting material was found to be very stable for $\mathrm{CO}_{2}$ reforming of $\mathrm{CH}_{4}$ for more than 90 hours. When $\mathrm{Co}_{6} \mathrm{~W}_{6} \mathrm{C}$ is heated in the presence of the feed mixture at $850^{\circ} \mathrm{C}$ and 5 atm total pressure for over 20 hours $\mathrm{CH}_{4}$ and $\mathrm{CO}_{2}$ rates of 1.3 and $1.25 \mathrm{mmol} / \mathrm{min} / \mathrm{g}$ respectively are obtained (Figure 5.14), with CO yields of $76 \%$ and $\mathrm{H}_{2} / \mathrm{CO}$ ratio close to unity. XRD patterns of the transformed catalyst suggest a phase transformation, at $850{ }^{\circ} \mathrm{C}$, from $\mathrm{Co}_{6} \mathrm{~W}_{6} \mathrm{C}$ to a mixture of $\mathrm{WC}+\mathrm{Co}+\mathrm{C}$. Scanning electron microscopy (SEM) images suggest the formation of encapsulated carbon as well as whisker carbon. These macroscopic carbon deposits could be due to the presence of Co in the catalyst, which is known to enhance carbon formation.

The kinetics of $\mathrm{CO}_{2}$ reforming of methane with $\mathrm{Co}_{6} \mathrm{~W}_{6} \mathrm{C}$ catalyst was studied under differential conditions over a temperature range of $500-600^{\circ} \mathrm{C}$, based on a detailed experimental design. The rates of formation of the products $\mathrm{H}_{2}, \mathrm{CO}$ and $\mathrm{H}_{2} \mathrm{O}$ were used for the kinetic analysis. The rate of $\mathrm{CO}$ production was always greater than the combined rates of $\mathrm{H}_{2}$ and $\mathrm{H}_{2} \mathrm{O}$ production for all reaction conditions.

A simple power-law model for the reforming kinetics was proposed for each of the product species $\left(\mathrm{H}_{2}, \mathrm{CO}\right.$ and $\left.\mathrm{H}_{2} \mathrm{O}\right)$. The model seems to fit the observed data well. Activation energies of $15-27 \mathrm{kcal} / \mathrm{mol}$ for different reaction species are obtained. These are consistent with the reported values from other studies. However, the model is incapable of incorporating all the mechanistic details involved in the reaction system. Hence, a simple L-H reaction scheme consisting of four reactions is considered, and the thermodynamic analysis showed that the reactions were not in equilibrium. The mechanism incorporates carbon deposition as well as carbon removal occurring in the 
reaction system, both of which are generally disregarded in most of the reported kinetic models. The parameters of the model were successfully estimated for all the experimental data. The comparison plots of the observed data and the predicted model show generally a good fit for all the product species in the reaction mixture.

\subsection{Recommendations for Future Work}

This project has demonstrated the performance of a cobalt tungsten carbide material as a catalyst precursor for methane dry reforming with carbon dioxide to produce synthesis gas. Besides, a kinetic investigation of this process lead to the development of a Langmuir-Hinshelwood model for efficiently predicting reaction rates of the products. There are certain reported concepts that could be incorporated as an extension of this research work.

Recently, Claridge et al. (1998) have reported of testing carbide catalysts under mixed oxidant conditions, feeding both water and carbon dioxide along with methane. This forms the combined reforming concept where both steam $\left(\mathrm{H}_{2} \mathrm{O}\right)$ and dry reforming $\left(\mathrm{CO}_{2}\right)$ reforming can be achieved simultaneously. One advantage of this method is that $\mathrm{H}_{2} / \mathrm{CO}$ ratios ranging from 1-3 can be produced by tuning the $\mathrm{CH}_{4} / \mathrm{CO}_{2} / \mathrm{H}_{2} \mathrm{O}$ feed ratio. Besides, the $\mathrm{H}_{2} \mathrm{O}$ present in the feed can suppress the carbon deposition during the $\mathrm{CH}_{4}$ $\mathrm{CO}_{2}$ reforming via gasification as follows:

$$
\mathrm{H}_{2} \mathrm{O}+\mathrm{C}_{(\mathrm{S})} \rightleftarrows \mathrm{CO}+\mathrm{H}_{2}\left(\Delta \mathrm{H}_{298}=31.4 \mathrm{kcal} / \mathrm{mol}\right)-----(7.1)
$$

Focusing on the current work of methane dry reforming with the $\mathrm{Co}_{6} \mathrm{~W}_{6} \mathrm{C}$ catalyst, the carbide catalyst could be tested at higher temperatures of about $1000{ }^{\circ} \mathrm{C}$. 
Brungs et al. (1999, 2000) and Claridge et al. (1998) have seen improved conversions for $\mathrm{CO}_{2}-\mathrm{CH}_{4}$ reforming with carbide catalysts at temperatures of about $950-1050{ }^{\circ} \mathrm{C}$. Thus, the reactant conversion would be predicted to reach near $100 \%$ for the operating conditions employed in our study. Besides, we have seen that the rate of RWGS reaction decreases at higher temperatures. This would augment the extent of methane reforming giving higher yields and better $\mathrm{H}_{2} / \mathrm{CO}$ ratios. However, the equipment needs to be modified such that it can operate at those temperatures.

In the experimental design during the kinetic study, the feed stream consisted of only the reactants $\mathrm{CH}_{4}$ and $\mathrm{CO}_{2}$. As an extension, the products such as $\left(\mathrm{H}_{2}, \mathrm{CO}\right)$ could be included in the feed stream. Thus, we can incorporate the inhibitive effects of the products, if any, on the reaction kinetics. Besides, the kinetic study could be performed at higher temperatures, so that any change in the reaction mechanism could be integrated into the mechanistic scheme.

Finally, from an industrial perspective, the goal should be focused on preparation and evaluation of supported molybdenum and tungsten carbide catalysts, which exhibit high activity and stability as well as resistance to carbon deposition. 


\section{REFERENCES}

Ashcroft A. T., Cheethan A. K., Green M. L. H. and Vernom P. D. F., Nature, 352, 225 (1991).

Bodrov I. M. and Apel'baum L. O, Kinet. Catal., 8, 326 (1967).

Bradford M. C. J. and Vannice M. A., Catal. Rev.- Sci. Eng., 41 (1), 1 (1999).

Bradford M. C. J. and Vannice M. A., J. Catal., 173, 157 (1998).

Bradford M. C. J., Ph.D. thesis, The Pennsylvania State University (1997).

Bradford M. C. J. and Vannice M. A., Appl. Catal. A: General, 142, 97 (1996).

Brungs A. J., York A.P.E, Claridge J. B, Marquez-Alvarez C., and Green M. L. H., Catal. Lett., 70, 117 (2000).

Brungs A. J., York A.P.E, and Green M. L. H., Catal. Lett., 57, 65 (1999).

Claridge J. B., York A. P. E., Brungs A.J., Marquez-Alvarez C., Sloan J., Tsang S. C. and Green M. L. H., J. Catal., 180, 85 (1998).

Efstathiou A. M., Kladi A., Tsipouriari V. A. and Verykios X. E., J. Catal., 158, 64 (1996).

Erdohelyi A., Cserenyi J., Papp E. and Solymosi F., Appl. Catal., 108, 205 (1994).

Erdohelyi A., Cserenyi J., Papp E. and Solymosi F., J. Catal., 141, 287 (1993).

Ferreira-Aparicio P., Marquez- Alvarez C., Rodriguez-Ramos I., Schuurman Y., Guerrero-Ruiz A. and Mirodatos C., J. Catal., 184, 202 (1999).

Fujmoto K., Omata K., Nozaki T., Yamazaki O. and Han Y., Energy Convers. Mgmt., 33, 529 (1992).

Gadalla A. M. and Bower B., Chem Eng. Sci., 42, 3049 (1988).

Gadalla A. M. and Sommer M. E., Chem Eng. Sci., 44, 2825 (1989).

Guerrero-Ruiz A., Rodriquez-Ramos I. and Sepulveda-Escribano A., Catal. Today, 21, 545 (1994).

Guerrero-Ruiz A., Rodriquez-Ramos I. and Sepulveda-Escribano A., J. Chem. Soc., Chem. Commun., 487 (1993). 
Hei M. J., Chen H. B., Yi J., Lin Y. J., Lin Y. Z., Wei G. and Liao D. W., Surf. Sci., 417, 82 (1998).

Horuichi T., Sakuma K., Fukui T., Kubo Y., Osaki T., and Mori T., Appl. Catal. A: General, 144, 111 (1996).

Hou K., and Hughes R., Chem. Eng. J., 82 (1-3), 311 (2001).

Kim G. J., Cho D. S., Kim K. H. and Kim J. H., Catal. Lett., 28, 41 (1994).

Kroll V. C. H., Swaan H. M., Lacombe S. and Mirodatos C., J. Catal., 164, 387 (1997).

Kroll V. C. H., Tjatjopoulos G. J. and Mirodatos C., Natural Gas Conversion V. (Stud. Surf. Sci. Catal.), 119, 753 (1998).

Kugler E. L., McCandlish L. E., Jacobson A. J. and Chianelli R. R., US Patent 5,138,111 (1992).

Lee H. H., Heterogeneous Reactor Design, Butterworth Publishers, Stoneham, MA, pp. 66 (1985).

Lee J. S., Oyama S. T. and Boudart M., J. Catal., 106, 125 (1987).

Levy R. B. and Boudart M., Science, 181, 547 (1973).

Lewis W. K., Gilliland E. R., and Reed W. A., Ind. Eng. Chem., 41, 1227 (1949).

Liu Z., Li X., Close M. R., Kugler E. L., Peterson J. L. and Dadyburjor D.B., Ind. Eng. Chem. Res., 36, 3085 (1997).

Lu. G. Q. and Wang S., Chemtech, 29 (1), 37 (1999).

Luo J. Z., Yu Z. L., Ng C. F. and Au C. T., J. Catal., 194, 198 (2000).

Mark M. F., Mark F and Maier W. F., Chem. Eng. Technol., 20, 361 (1997).

Mark M. F., and Maier W. F., J. Catal., 164, 122 (1996).

Masai M., Kado H., Miyake A., Nishiyama S. and Tsuruya S., Stud. Surf. Sci. Catal., 36, 67 (1988).

Namakura J., Aikawa K., Sato K. and Uchijima T., Catal. Lett., 25, 265 (1994).

Olsbye U., Wurzel T. and Mleczko L., Ind. Eng. Chem. Res., 36, 5180 (1997).

Osaki T., Fukaya H., Horiuchi T., Suzuki K. and Mori T., J. Catal., 180, 106 (1998). 
Osaki T., Horiuchi T., Suzuki K. and Mori T., Appl. Catal. A: General, 155, 229 (1997).

Osaki T., Horiuchi T., Suzuki K. and Mori T., Catal. Lett., 35, 39 (1995).

Oshikawa K., Nagai M., and Omi S., Chem. Lett., 1086 (2000).

Otsuka K., Ushiyama T., and Yamanaka I., Chem. Lett., 1517 (1993).

Oyama S. T., Ph.D. dissertation, Stanford University (1981).

Park S. E., Nam S. S., Choi M. J. and Lee K. W., Energy Convers. Mgmt., 36, 573 (1995).

Perera J. H. S. Q, Couves J. W, Sankar G. and Thomas J. M., Catal. Lett., 11, 219 (1991).

Polizzotti R. S., McCandlish L. E., and Kugler E. L., US Patent 5,338,330 (1994).

Richardson J. T. and Paripatyadar S. A., Appl. Catal., 61, 293-309 (1990).

Ross J. R. H., Keulen van A. N. J., Hegarty M. E. S. and Seshan K., Catal. Today, 30, 193 (1996).

Rostrup-Neilson J. R. and Bak-Hansen J. H., J. Catal., 144, 38 (1993).

Sakai Y., Saito H., Sodesawa T. and Nozaki F., React. Kinet Catal. Lett., 24, 253 (1984).

Sandler S. I., Chemical Engineering Thermodynamics, $2^{\text {nd }}$ edition, John Wiley \& Sons, Inc., New York (1989).

Seshan K., Barge T. H. W., Hally W., Keulen van A. N. J. and Ross J. R. H., Natural Gas Conversion II (Curry-Hyde H. E. and Howe R. F., eds.), Elsevier, Amsterdam pp. 285 (1994).

Shamsi A. and Lyons D., Proceedings of $219^{\text {th }}$ National Meeting, American Chemical Society, March 2000, 132 (2000).

Silva A. E. M., Hudgins R. R., and Silveston P. L., Can. J. Chem Eng., 57 (2), 176-182 (1979).

Swaan H. M., Kroll V. C. H., Martin G. A. and Mirodatos C., Catal. Today, 21, 571 (1994).

Takano A., Tagawa T. and Goto S., J. Chem Eng. Jpn., 27, 723 (1994).

Takayasu O., Hirose E., Matsuda N., and Matsuura I., Chem. Express., 6, 447 (1991). 
Teuner, S., Hydrocarbon Process., 64 (5), 106 (1985).

Togunaga O. and Ogasawara S., React. Kinet Catal. Lett., 39, 69 (1989).

Tsipouriari V. A., Efstathiou A. M. and Verykios X. E., Catal. Today, 21, 579 (1994).

Tsuji M., Miyao T., and Naito S., Catal. Lett., 69, 195 (2000).

Vannice M. A., Hyun S. H., Kalpakci B., and Liauh W. C., J. Catal., 56, 358 (1979).

Vernon P. D. F., Green M. L. H., Cheetham A. K., and Ashcroft A. T., Catal. Today., 13, 417 (1992).

Vreugdenhil W., Sherif F. G., Burk J. H. and Gadberry J. F., US Patent 5,321,161 (1994).

Wang S. and Lu. G.Q., React. Eng. Pollut. Prev., 75 (2000).

Wang S., Lu. G.Q. and Millar G. J., Energy Fuels, 10, 896 (1996).

York A. P. E., Chem. Brit., 25 (1999).

Zhang Z. L. and Verykios X. E., Catal. Today, 21, 589 (1994). 


\section{APPENDICES}




\section{APPENDIX A: Gas Chromatograph Operating \\ Conditions}


Gas chromatograph model: Hewlett-Packard 5890 II

Detector used: Thermal-conductivity detector (TCD)

Detector temperature: $255^{\circ} \mathrm{C}$

Carrier gas: Argon

Carrier gas inlet pressure: 85 psig.

Total carrier gas flow rate: $68.5 \mathrm{scc} / \mathrm{min}$

Reference flow rate: $44 \mathrm{scc} / \mathrm{min}$

Column Flow rate: $24.5 \mathrm{scc} / \mathrm{min}$

Columns used: HayeSep-DB packed column and J\&W DBWax capillary column

Oven temperature (both columns): $150{ }^{\circ} \mathrm{C}$

Mode of operation: isothermal

Injector A (auto-injection) temperature: $150{ }^{\circ} \mathrm{C}$

Injector B (manual-injection) temperature: $150{ }^{\circ} \mathrm{C}$

Period of analysis: $15 \mathrm{~min}$. 


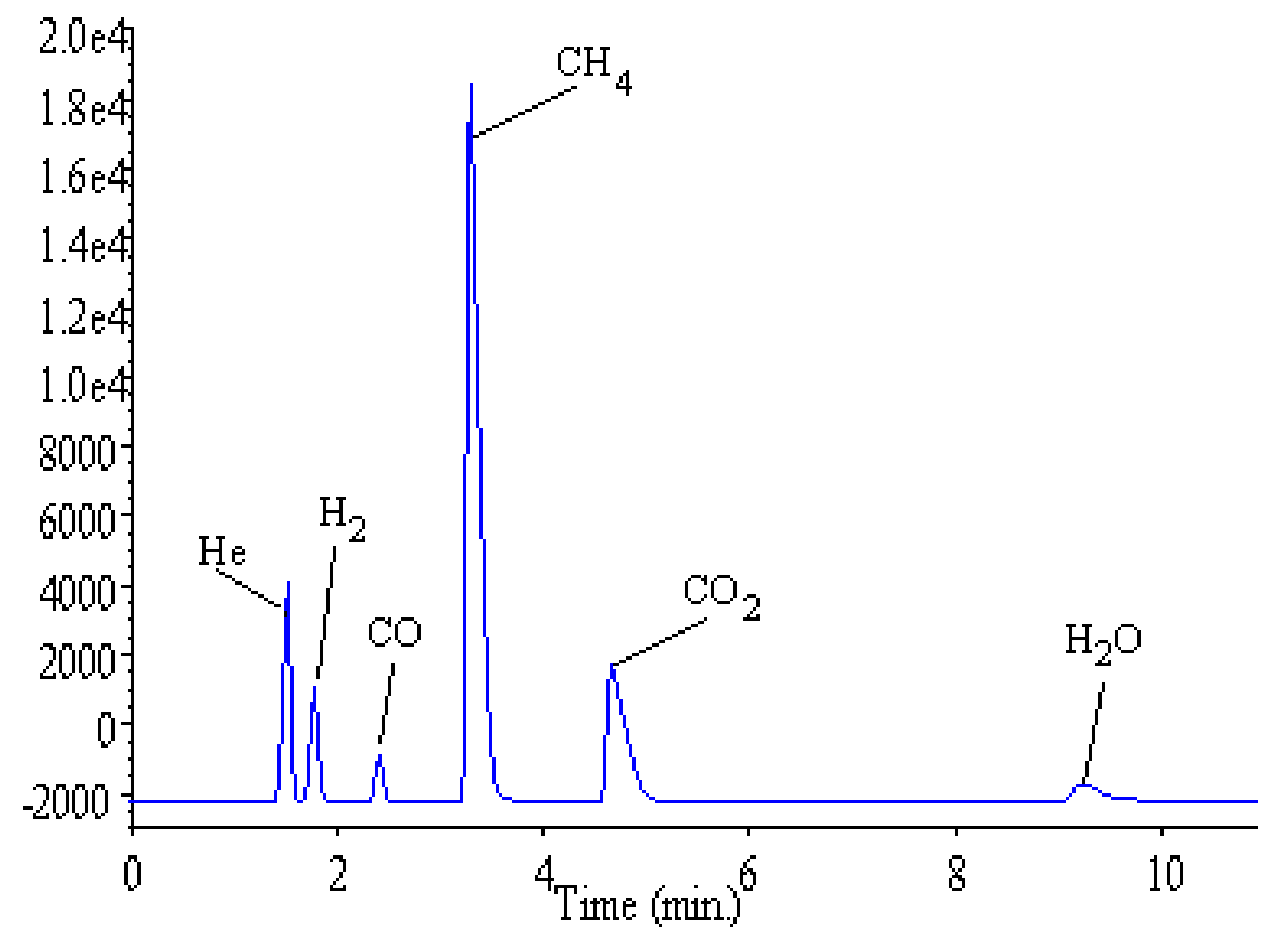

Figure A.1 A typical chromatogram showing separation of different species for $\mathrm{CO}_{2}$ reforming of $\mathrm{CH}_{4}$. Obtained using $\mathrm{Ni} / \mathrm{Al}_{2} \mathrm{O}_{3}$ catalyst (120-170 mesh size), $\mathrm{T}=700$ oC; feed ratio $=\mathrm{CH}_{4}: \mathrm{CO}_{2}: \mathrm{Ar}=1: 3.7: 4.9$. 


\section{APPENDIX B: Calculation Procedure for Gas Chromatograph Calibration}




\section{B.1 Calculation for Analysis of $\mathrm{He}, \mathrm{H}_{2}, \mathrm{CO}, \mathrm{CH}_{4}$ and $\mathrm{CO}_{2}$}

For the calibration, a stream of component $\mathrm{x}$ (where $\mathrm{x}=\mathrm{He}, \mathrm{H}_{2}, \mathrm{CO}, \mathrm{CH}_{4}$ or $\mathrm{CO}_{2}$ ) is mixed with a stream of Ar. The ratio of the mixture is predetermined. The mixture is then automatically injected; from the sampling loop; into the $\mathrm{GC}$ injection port A, by the auto-injector. The temperature of the loop and the pressure in the loop is noted. The GC output from the TCD is noted. The calculations are as given below.

Volume of the GC sampling loop $=0.5 \mathrm{cc}$

Fraction of the gas species " $\mathrm{x}$ " in the injected sample, $f=\underline{\text { Molar flow of the species } \mathrm{x}}$ (Molar flow of $\mathrm{Ar}+\mathrm{x}$ )

Volume of the species " $\mathrm{x}$ " in the loop, $\mathrm{V}_{2}=(\mathrm{f} * 0.5) \mathrm{cc}$

Temperature of the loop $=\mathrm{T}_{2} \mathrm{~K}$

Absolute pressure in the loop $=\mathrm{P}_{2}$ atm.

Assuming ideal gas law holds good for all these gas species,

$\mathrm{V}_{1}=\left(\mathrm{P}_{2} / \mathrm{P}_{1}\right) *\left(\mathrm{~T}_{1} / \mathrm{T}_{2}\right) * \mathrm{~V}_{2}$

where,

$$
\begin{aligned}
& \mathrm{V}_{1}=\text { volume of the species " } \mathrm{x} \text { " in the loop at STP conditions, cc } \\
& \mathrm{P}_{1}=\text { atmospheric pressure, } 1 \mathrm{~atm} \\
& \mathrm{~T}_{1}=\text { temperature at STP conditions, } 273 \mathrm{~K}
\end{aligned}
$$

The moles of species " $x$ " in the loop, $n_{1}=V_{1} / 22400$

Let this injection have a peak $A_{1}$. 
Similarly, for different fractions $\mathrm{f}$, the area counts A are observed and a plot of A vs $\mathrm{n}$ is obtained as the calibration curve (Figures B.1 -B.6). The slopes (C) thus obtained from these plots are used for analysis. The slope $\mathrm{C}_{\mathrm{x}}$, for every species $\mathrm{x}$, has a unit of area count $/ \mathrm{mol}$.

\section{B.2 Calculation for Analysis of $\mathrm{H}_{2} \mathrm{O}$}

$\mathrm{H}_{2} \mathrm{O}$ is calibrated by manually injecting known liquid volumes through the injection port B, using a Hamilton micro-liter syringe. The GC output from the TCD is then noted. The calculations are as given below.

Volume of the water sample injected $=\mathrm{V}_{1} \mu \mathrm{L}$

Observed area count for the injected sample $=\mathrm{A}_{1}$

Density of water, $\mathrm{d}=1 \mathrm{~g} / \mathrm{ml}$

Molecular weight of water injected $=18 \mathrm{~g} / \mathrm{mol}$

Moles of water injected, $\mathrm{n}_{1}=\frac{\left(\mathrm{V}_{1} * \mathrm{~d}\right) * 10^{-3}}{18}$

A calibration plot of $\mathrm{A}$ vs $\mathrm{n}$ is obtained by injecting different volumes $\mathrm{V}$ and the slope thus obtained is used for analysis. 


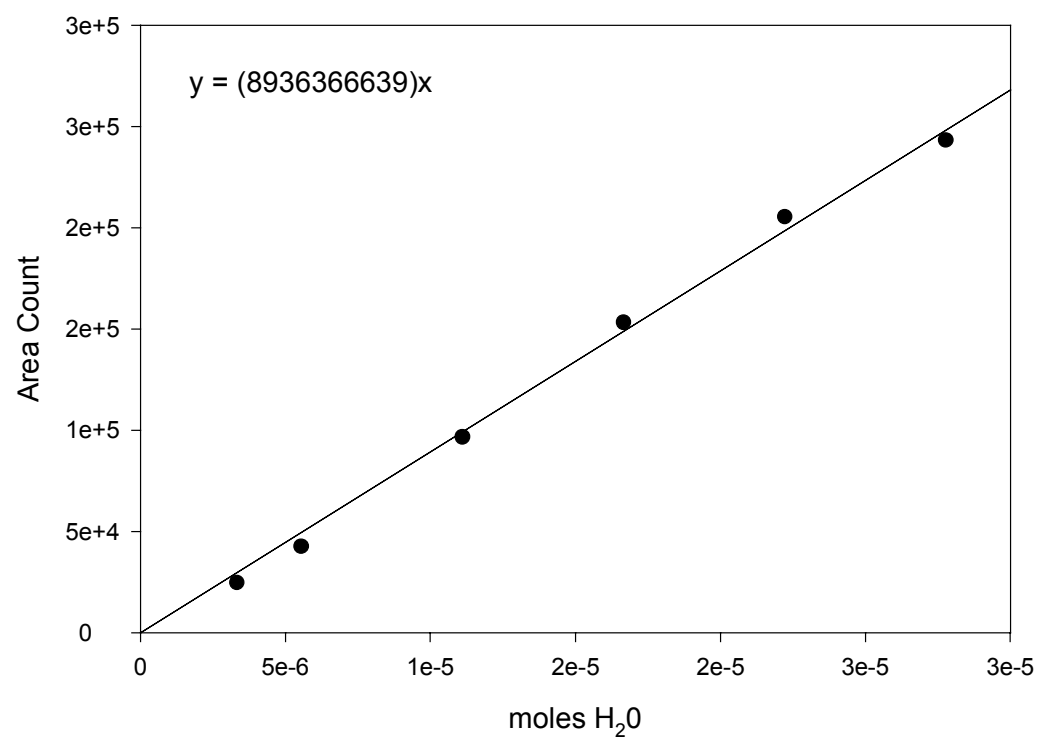

Figure B.1 GC calibration curve for $\mathrm{H}_{2} \mathrm{O}$

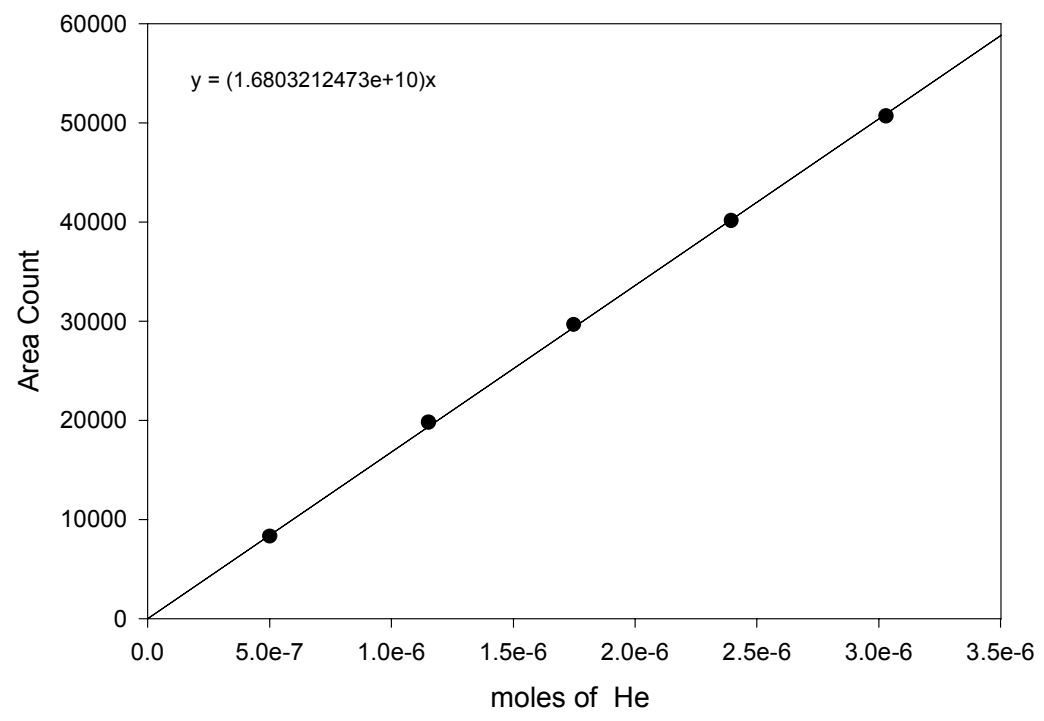

Figure B.2 GC calibration curve for $\mathrm{He}$ 


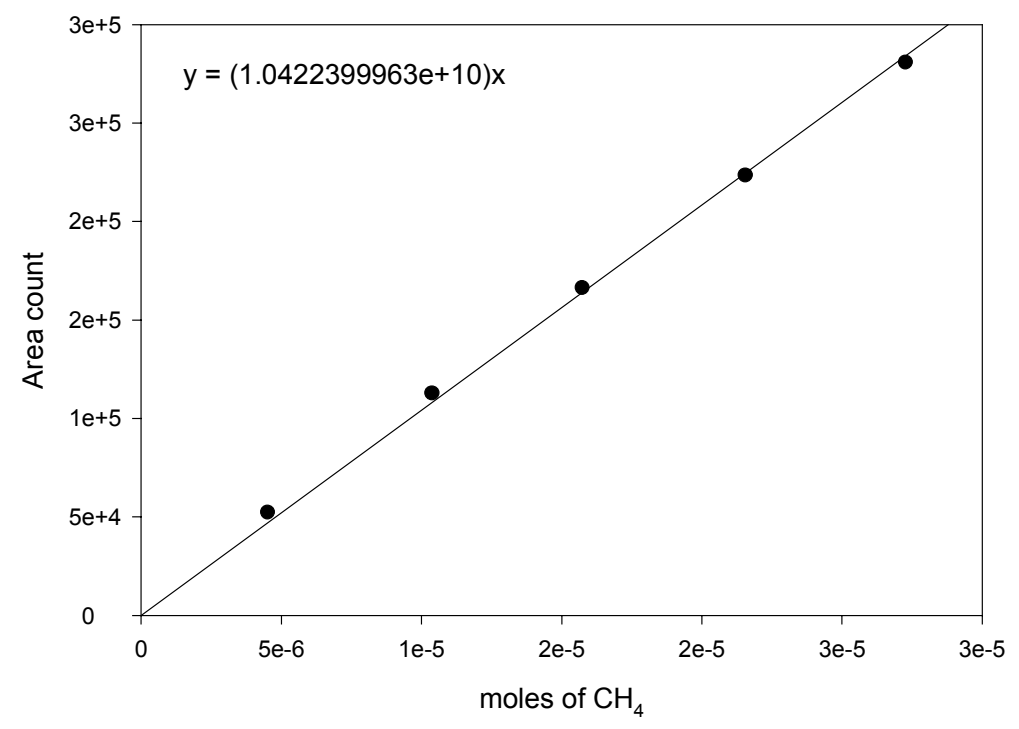

Figure B.3 GC calibration curve for $\mathrm{CH}_{4}$

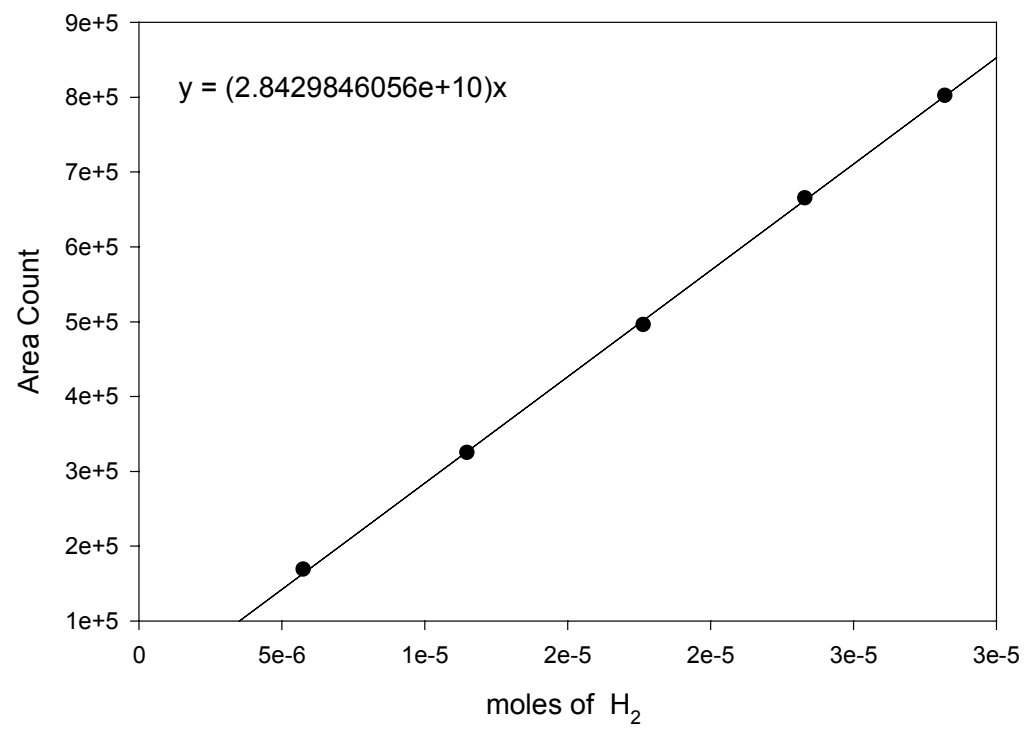

Figure B.4 GC calibration curve for $\mathrm{H}_{2}$ 


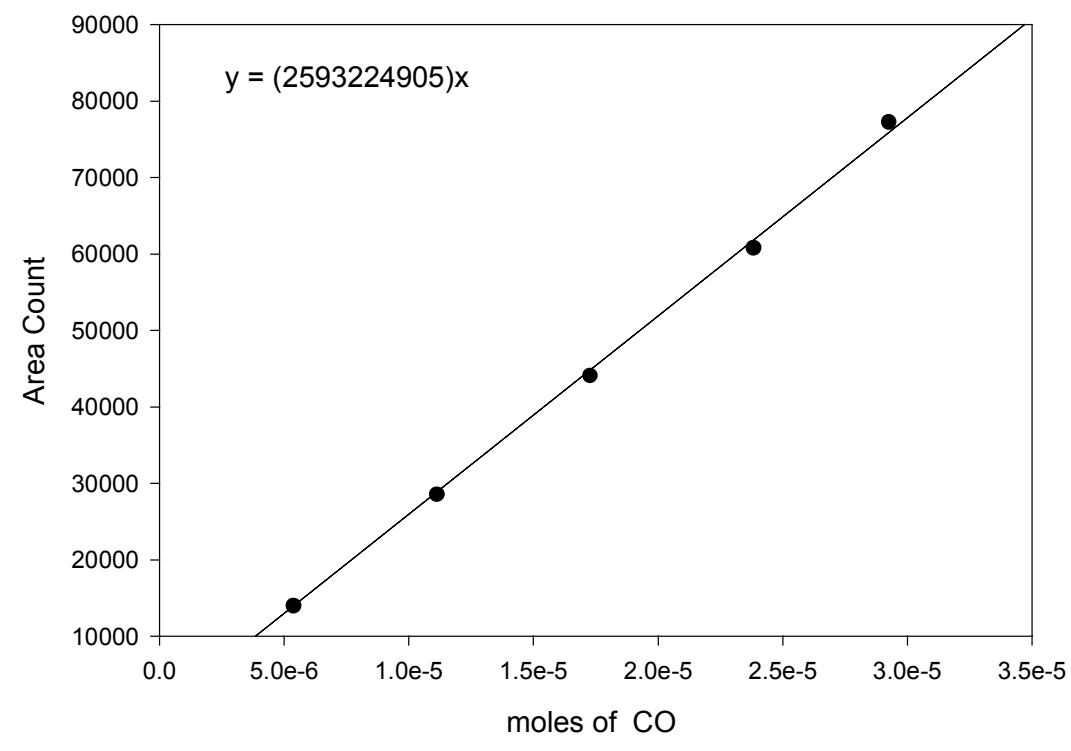

Figure B.5 GC calibration curve for CO

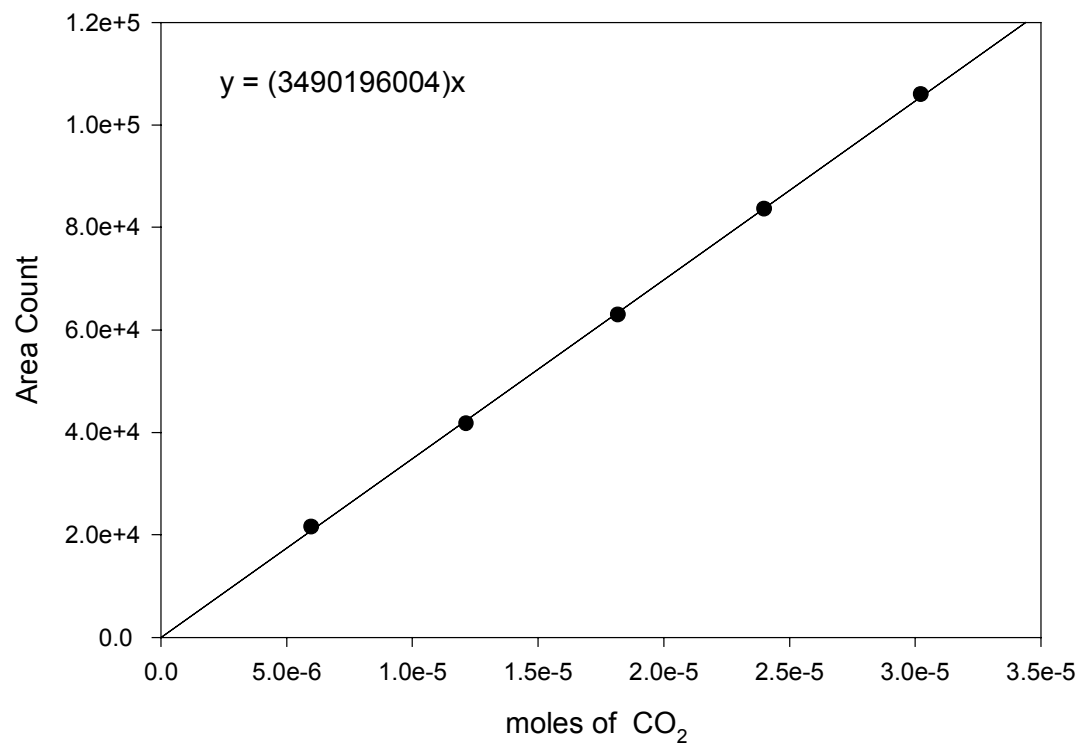

Figure B.6 GC calibration curve for $\mathrm{CO}_{2}$ 


\section{APPENDIX C: Mass Flow Controller Calibration Curves}


The catalyst-testing unit (Figure 3.1) has four lines for gas feed, each being independently controlled by a Brooks mass-flow controller (MFC). Each of the MFCs was pre-assigned to a specific feed gas except the one, labeled "Aux" (Figure 3.1), where $\mathrm{CO}$ and $\mathrm{H}_{2}$ were used when required. The room temperature is maintained constant at 21 ${ }^{\circ} \mathrm{C}$ during the entire calibration process. The MFCs are enclosed in an insulated Styrofoam container to minimize the effects of room temperature changes on the calibration process. The gas flow rate is preset to the maximum set value on the MFC and the system is allowed to reach a steady state. The volumetric flow at the outlet is then measured using a bubble flow meter. The room temperature and pressure is also noted. The readings are then repeated similarly for other MFC set values and a calibration curve is obtained. The calculations are as given below.

Volumetric flow rate of the gas (as measured by bubble flow meter) $=\mathrm{V}_{2} \mathrm{cc} / \mathrm{min}$ Ambient temperature $=\mathrm{T}_{2} \mathrm{~K}$

Ambient pressure $=\mathrm{P}_{2} \mathrm{~mm} \mathrm{Hg}$

Assuming ideal gas law holds true for all the gas species:

Volumetric flow rate of the gas at STP conditions are:

$$
\mathrm{V}_{1}=\left(\mathrm{P}_{2} / \mathrm{P}_{1}\right) *\left(\mathrm{~T}_{1} / \mathrm{T}_{2}\right) * \mathrm{~V}_{2}\{\mathrm{cc} / \mathrm{min}\}
$$

where,

$$
\begin{aligned}
& \mathrm{V}_{1}=\text { volume of the species " } \mathrm{x} \text { " in the loop at STP conditions, cc } \\
& \mathrm{P}_{1}=\text { atmospheric pressure, } 760 \mathrm{~mm} \mathrm{Hg} \\
& \mathrm{T}_{1}=\text { temperature at STP conditions, } 273 \mathrm{~K}
\end{aligned}
$$

Hence, the molar flow rate of the gas, $\mathrm{n}=\mathrm{V}_{1} / 22400\{\mathrm{~mol} / \mathrm{min}\}$

The plots of $\mathrm{n}$ vs MFC set values are thus obtained for all gases. 


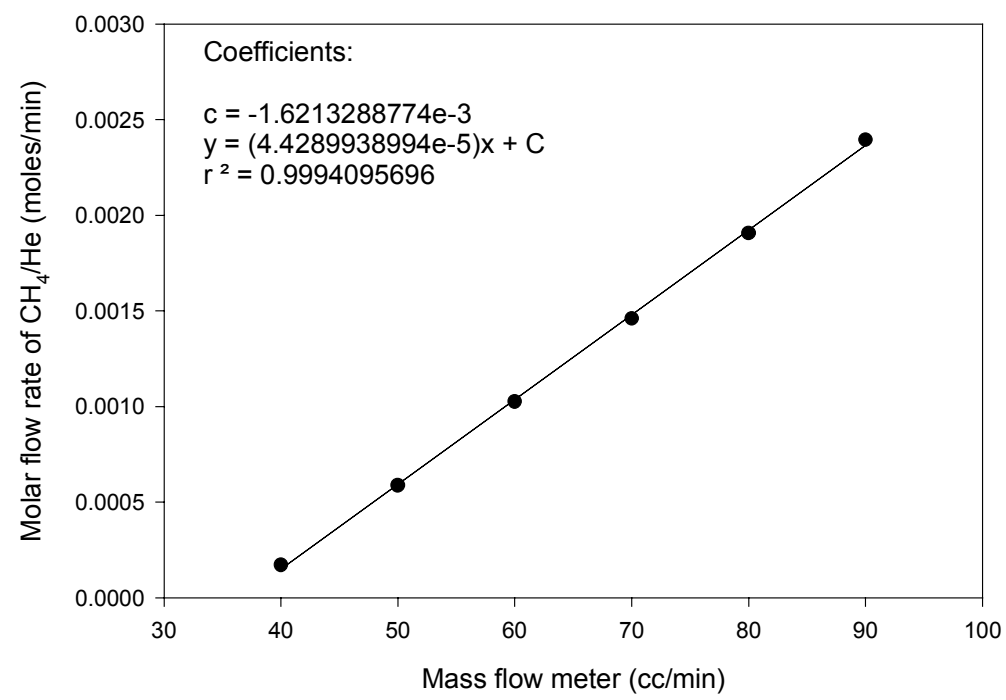

Figure C.1 MFC calibration curve for $\mathrm{CH}_{4} / \mathrm{He}$ mixture

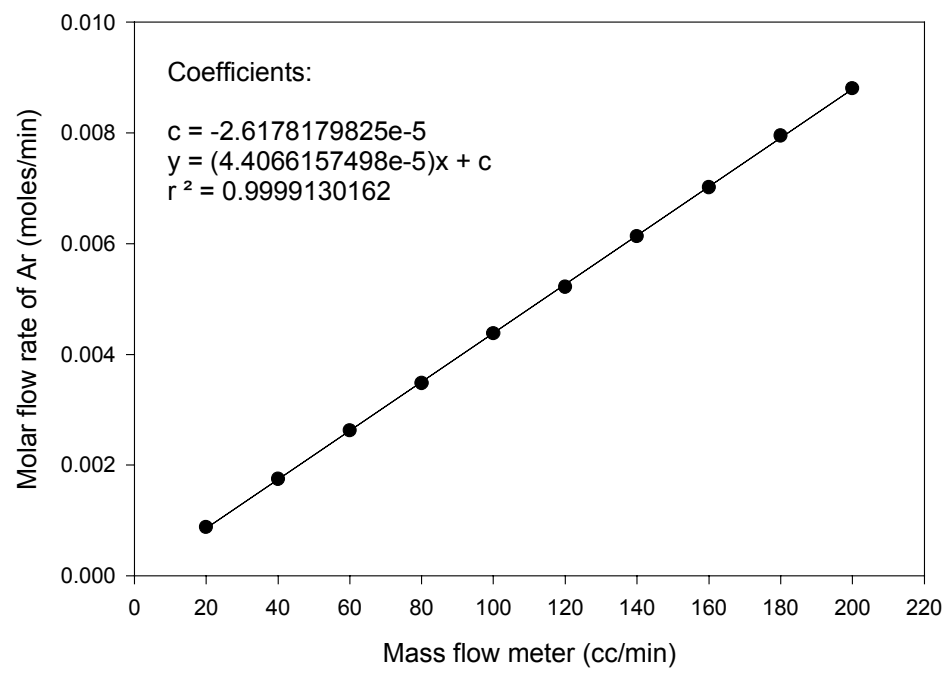

Figure C.2 MFC calibration curve for Ar 


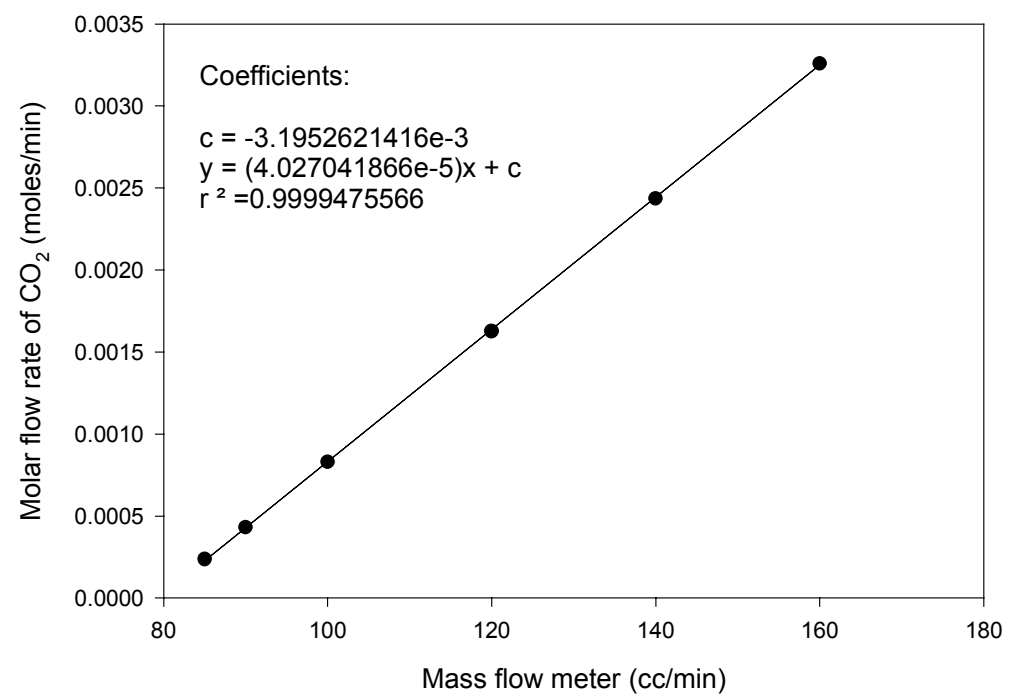

Figure C.3 MFC calibration curve for $\mathrm{CO}_{2}$

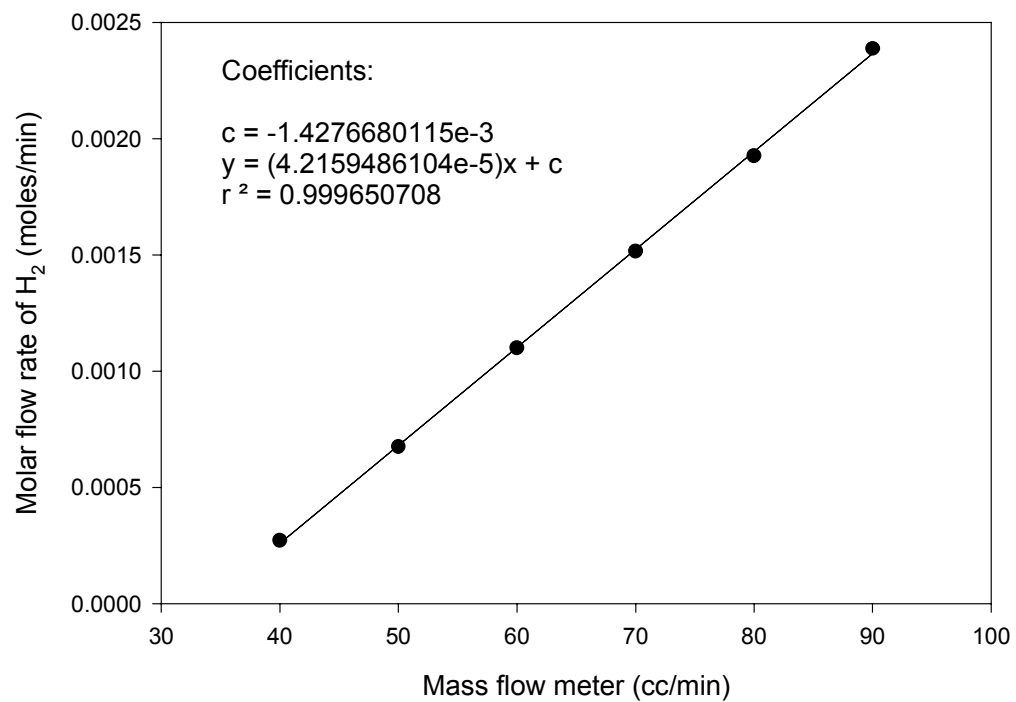

Figure C.4 MFC calibration curve for $\mathbf{H}_{2}$ 


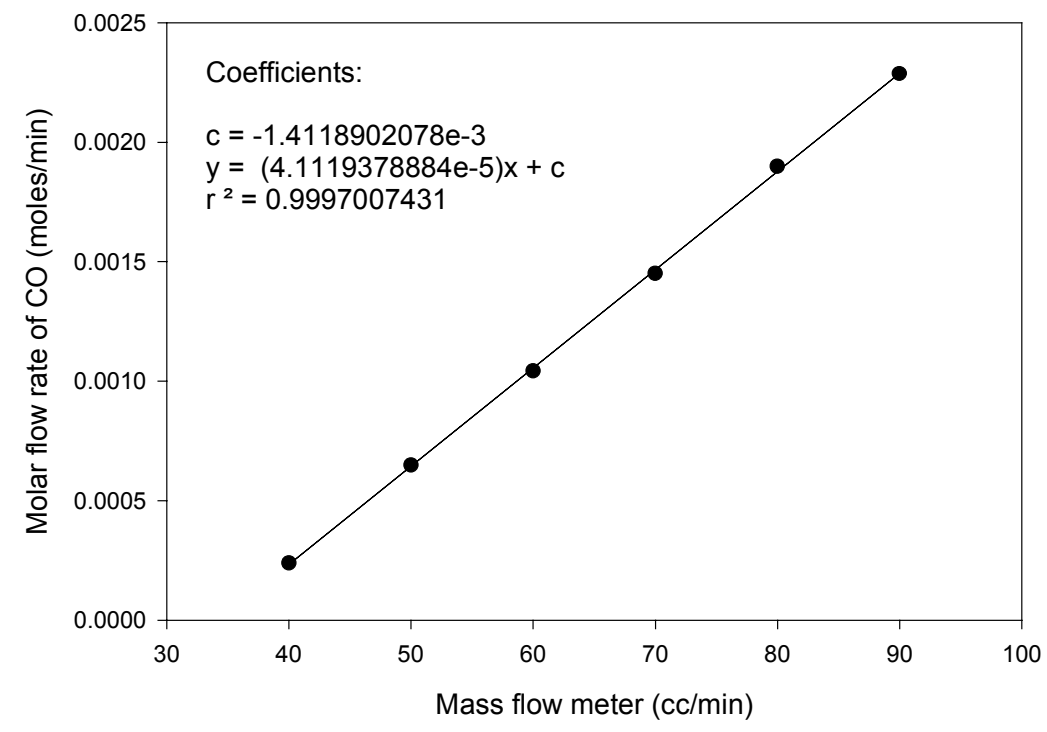

Figure C.5 MFC calibration curve for CO 
APPENDIX D: Calculations for Results with Supported Nickel and Platinum Catalysts 


\section{D.1 Calculations of Reaction Rates for $\mathrm{Ni} / \mathrm{Al}_{2} \mathrm{O}_{3}$ Catalyst (Without Internal Standard)}

In all the experiments with the Ni catalysts, there was no internal standard used. The calculations of reaction rates were based on the volumetric flow rates of the product stream at the exit of the reactor.

Molar flow rate of any species $\mathrm{x}$ at the reactor inlet $=\left(\mathrm{F}_{\mathrm{X}}\right)_{\mathbb{I N}} \quad\{\mathrm{mol} / \mathrm{min}\}$

where $\mathrm{x}=\mathrm{CH}_{4}, \mathrm{CO}_{2}$, Ar.

These inlet flow rates are obtained from the Mass Flow Controller (MFC) calibration the details of which can be obtained in Appendix C.

Let $\mathrm{C}_{\mathrm{X}}$ \{area count $\left./ \mathrm{mol}\right\}$ be the slope of the GC calibration curve obtained for each of the species $\left(\mathrm{x}=\mathrm{H}_{2}, \mathrm{CO}, \mathrm{CH}_{4}, \mathrm{CO}_{2}, \mathrm{H}_{2} \mathrm{O}\right)$. The details are given in Appendix $\mathrm{B}$.

Let $A_{X}$ be the area count of each of the species obtained from the GC response by injecting a sample volume from the sampling loop.

Moles of species x, present in the sample loop,

$\mathbf{n}_{\mathbf{X}}=\mathbf{A}_{\mathbf{X}} / \mathbf{C}_{\mathbf{X}}\{\mathrm{mol} / \mathrm{min}\}$

Volume of the sampling loop $=0.5 \mathrm{cc}$

Temperature of the sampling loop $=\mathrm{T}_{1} \mathrm{~K}$

Ambient (room) temperature $=\mathrm{T}_{2} \mathrm{~K}$

Volumetric flow rate of the product stream at the reactor outlet $=\mathrm{V}_{\text {out }}\{\mathrm{cc} / \mathrm{min}\}$

$\mathrm{V}_{\text {out }}$ was measured at ambient temperature and pressure.

Now, molar flow rate of any species $\mathrm{x},\left(\mathrm{x}=\mathrm{H}_{2}, \mathrm{CO}, \mathrm{CH}_{4}, \mathrm{CO}_{2}, \mathrm{H}_{2} \mathrm{O}\right)$ at the reactor outlet, $\left(\mathbf{F}_{\mathbf{X}}\right)_{\text {out }}=\left[\mathbf{n}_{\mathbf{X}} / \mathbf{0 . 5}\right] *\left[\mathbf{T}_{\mathbf{1}} / \mathbf{T}_{\mathbf{2}}\right] * \mathbf{V}_{\text {out }}\{\mathrm{mol} / \mathrm{min}\}$

It is assumed that there is no change in the molar flow rates of $\mathrm{Ar}$ (inert). 
Conversion of any reactant species $\mathrm{x}\left(\mathrm{x}=\mathrm{CH}_{4}, \mathrm{CO}_{2}\right)$ is given as:

$\%$ Conversion of $x=\left[\left(F_{X}\right)_{I N}-\left(F_{X}\right)_{\text {OUT }}\right] /\left(F_{X}\right)_{I N}$

Net rate of formation for any product species (for $\mathrm{x}=\mathrm{H}_{2}, \mathrm{CO}, \mathrm{H}_{2} \mathrm{O}$ )

$\mathbf{r}_{\mathbf{X}}=\left(\mathbf{F}_{\mathbf{X}}\right)_{\text {OUT }} / \mathbf{W} \quad\{\mathrm{mol} / \mathrm{min} /$ gcat $\}$

Total rate of formation of any reactant species (for $\mathrm{x}=\mathrm{CH}_{4}, \mathrm{CO}_{2}$ )

$\mathbf{r}_{\mathbf{X}}=\left[\left(\mathbf{F}_{\mathbf{X}}\right)_{\mathbf{I N}}-\left(\mathbf{F}_{\mathbf{X}}\right)_{\text {out }}\right] / \mathbf{W} \quad\{\mathrm{mol} / \mathrm{min} /$ gcat $\}$

where,

$\mathrm{W}=$ weight of the catalyst used (grams)

$\left(\mathrm{F}_{\mathrm{X}}\right)_{\text {OUT }}=$ molar flow rate of any species $\mathrm{x}$ at the reactor outlet as given by eq. D.2.

\section{D.2 Calculations of Reaction Rates for $\mathrm{Pt} / \mathrm{ZrO}_{2}$ Catalyst (Without Internal Standard)}

The calculation procedure is similar to that followed for $\mathrm{Ni} / \mathrm{Al}_{2} \mathrm{O}_{3}$ catalyst. The only exception is that for the calculation of the reactant conversion. In this case, the total reactant conversion was calculated instead calculating the conversion for each species, as the conversions were significantly low. The calculation for the total reactant conversion is as follows:

$\%$ Conversion $=\frac{\left(n_{\mathrm{H} 2}+n_{\mathrm{CO}}\right) / 2}{\left\{\left(\mathbf{n}_{\mathrm{CH} 4}+\mathbf{n}_{\mathrm{CO} 2}\right)+\left(\mathbf{n}_{\mathrm{H} 2}+\mathbf{n}_{\mathrm{CO}}\right) / 2\right\}}$

where,

$\mathrm{n}_{\mathrm{X}}=$ moles of species $\mathrm{x}$ in the sampling loop and is calculated as given by eq. D.1 
APPENDIX E: Calculations for the Results with Cobalt

\section{Tungsten Carbide Catalyst}




\section{E.1 Calculation of Reaction Rates and Partial Pressures}

\section{E.1.1 Reaction Rates}

Molar flow rate of $\mathrm{CH}_{4} / \mathrm{He}$ mixture at the reactor inlet as obtained from the Mass Flow Controller (MFC) calibration $=\mathrm{F}_{\mathrm{MIX}} \quad\{\mathrm{mol} / \mathrm{min}\}$

As the certified $\mathrm{CH}_{4} / \mathrm{He}$ gas mixture contains $10 \% \mathrm{He}$ and the rest is $\mathrm{CH}_{4}$, we get the individual flow rates as follows:

Molar flow rate of $\mathrm{He}$ at the reactor inlet, $\left(\mathrm{F}_{\mathrm{He}}\right)_{\mathrm{IN}}=(0.1) * \mathrm{~F}_{\mathrm{MIX}} \quad\{\mathrm{mol} / \mathrm{min}\}$

Molar flow rate of $\mathrm{CH}_{4}$ at the reactor inlet, $\left(\mathrm{F}_{\mathrm{CH} 4}\right)_{\mathrm{IN}}=(0.9) * \mathrm{~F}_{\mathrm{MIX}} \quad\{\mathrm{mol} / \mathrm{min}\}$

Molar flow rate of $\mathrm{CO}_{2}$ at the reactor inlet as obtained from the MFC calibration = $\left(\mathrm{F}_{\mathrm{CO} 2}\right)_{\mathbb{N}}\{\mathrm{mol} / \mathrm{min}\}$

Molar flow rate of Ar at the reactor inlet as obtained from the MFC calibration $=\left(\mathrm{F}_{\mathrm{Ar}}\right)_{\mathrm{IN}}$ $\{\mathrm{mol} / \mathrm{min}\}$

Let $\mathrm{C}_{\mathrm{X}}$ \{area count $\left./ \mathrm{mol}\right\}$ be the slope of the GC calibration curve obtained for each of the species $\left(\mathrm{x}=\mathrm{He}, \mathrm{H}_{2}, \mathrm{CO}, \mathrm{CH}_{4}, \mathrm{CO}_{2}, \mathrm{H}_{2} \mathrm{O}\right)$. The details are given in Appendix $\mathrm{B}$. As mentioned earlier, $\mathrm{He}$ is used as the internal standard.

Let $A_{X}$ be the area count of each of the species obtained from the GC response by injecting a sample volume from the sampling loop.

Moles of species x, present in the sampling loop,

$\mathbf{n}_{\mathbf{X}}=\mathbf{A}_{\mathbf{X}} / \mathbf{C}_{\mathbf{X}}\{\mathrm{mol} / \mathrm{min}\}$

Similarly, moles of He in the sampling loop,

$\mathbf{n}_{\mathrm{He}}=\mathbf{A}_{\mathbf{H e}} / \mathbf{C}_{\mathrm{He}} \quad\{\mathrm{mol} / \mathrm{min}\}$

Now, molar flow rate of any species $\mathrm{x}$ at the reactor outlet, 
$\left(\mathbf{F}_{\mathbf{X}}\right)_{\text {out }}=\left\{\mathbf{n}_{\mathbf{X}} / \mathbf{n}_{\mathbf{H e}}\right\} *\left(\mathbf{F}_{\mathbf{H e}}\right)_{\mathbf{I N}}\{\mathrm{mol} / \mathrm{min}\}$

It is assumed that there is no change in the molar flow rates of $\mathrm{He}$ and $\mathrm{Ar}$ as they are the inerts and do not take part in any reaction.

Total rate of formation of products (for $\mathrm{x}=\mathrm{H}_{2}, \mathrm{CO}, \mathrm{H}_{2} \mathrm{O}$ )

$\mathbf{S}_{\mathbf{1 X}}=\left(\mathbf{F}_{\mathbf{X}}\right)_{\text {OUT }}\{\mathrm{mol} / \mathrm{min}\}$

Total rate of consumption of reactants (for $\mathrm{x}=\mathrm{CH}_{4}, \mathrm{CO}_{2}$ )

$\mathbf{R}_{\mathbf{1 X}}=\left(\mathbf{F}_{\mathbf{X}}\right)_{\mathbf{I N}}-\left(\mathbf{F}_{\mathbf{X}}\right)_{\text {out }}\{\mathrm{mol} / \mathrm{min}\}$

From the blank reactor runs it has been seen that the empty reactor shows some catalytic activity between $750-850{ }^{\circ} \mathrm{C}$ (section 5.3.2). The rates of formation/consumption for the blank reactor runs are calculated as given above (eqs. E.1 - E.5). Hence, the total rates of formation of each species obtained from the blank reactor runs are subtracted from those obtained for the actual runs for catalyst testing. The reaction conditions such as the feed flow rates, operating pressures and temperatures are maintained identical for the blank runs and the actual catalytic testing. The details of these calculations are as shown below:

Net corrected total rate of formation of products,

$\mathbf{S}_{\mathbf{X}}=\mathbf{S}_{\mathbf{1 X}}-\mathbf{S}_{\mathbf{0 X}}\{\mathrm{mol} / \mathrm{min}\}$

Net corrected total rate of consumption of reactants,

$\mathbf{R}_{\mathbf{X}}=\mathbf{R}_{\mathbf{1 X}}-\mathbf{R}_{\mathbf{0 X}}\{\mathrm{mol} / \mathrm{min}\}$

where,

$\mathrm{S}_{0 \mathrm{X}}=$ total rate of formation of products from the blank reactor runs

$\mathrm{R}_{0 \mathrm{X}}=$ total rate of consumption of reactants from the blank reactor runs

$\mathrm{S}_{1 \mathrm{X}}=$ total rate of formation of products from the catalytic runs 
$\mathrm{R}_{1 \mathrm{X}}=$ total rate of consumption of reactants from the catalytic runs

Thus, net rate of formation of any species (for $\mathrm{x}=\mathrm{H}_{2}, \mathrm{CO}, \mathrm{CH}_{4}, \mathrm{CO}_{2}, \mathrm{H}_{2} \mathrm{O}$ ) is given by:

$\mathbf{r}_{\mathbf{X}}=\left(\mathbf{S}_{\mathbf{X}} / \mathbf{W}\right)$ (for products) or

$\mathbf{r}_{\mathbf{x}}=\left(-\mathbf{R}_{\mathbf{X}} / \mathbf{W}\right)$ (for reactants) $\{\mathrm{mol} / \mathrm{min} / \mathrm{gcat}\}$

where,

$\mathrm{S}_{\mathrm{X}}$ and $\mathrm{R}_{\mathrm{X}}$ are as calculated in eqs. E.6 and E.7 above.

$\mathrm{W}=$ weight of the catalyst used (grams)

\section{E.1.2 Partial Pressures}

$P_{X}=\left(\frac{\left(F_{X}\right)_{\text {OUT }}}{\sum_{X}\left(F_{X}\right)_{\text {OUT }}+\left(F_{H e}\right)_{I N}+\left(F_{A r}\right)_{I N}}\right) P_{T}$

where,

$\mathrm{P}_{\mathrm{X}}=$ partial pressure of any species $\mathrm{x},\left(\mathrm{x}=\mathrm{H}_{2}, \mathrm{CO}, \mathrm{CH}_{4}, \mathrm{CO}_{2}, \mathrm{H}_{2} \mathrm{O}\right)\{\mathrm{atm}\}$

$\left(\mathrm{F}_{\mathrm{X}}\right)_{\mathrm{OUT}}=$ molar flow rate of any species $\mathrm{x}$ at the reactor outlet, as given by eq. E. 3 $\{\mathrm{mol} / \mathrm{min}\}$

$\mathrm{P}_{\mathrm{T}}=$ total pressure in the reactor $\{\mathrm{atm}\}$

$\left(\mathrm{F}_{\mathrm{Ar}}\right)_{\mathbb{N}},\left(\mathrm{F}_{\mathrm{He}}\right)_{\mathbb{I N}}=$ molar flow rate of $\mathrm{Ar}$ and $\mathrm{He}$ at the reactor inlet $\{\mathrm{mol} / \mathrm{min}\}$ 


\section{E.2 Calculations of Conversions, Yield, $\mathrm{H}_{2} / \mathrm{CO}$ ratio and Carbon balance}

\section{E.2.1 Conversions of $\mathrm{CH}_{4}$ and $\mathrm{CO}_{2}$}

Conversion of any reactants species $\mathrm{x}$ is given as:

$\%$ Conversion of $x=\left[R_{X} /\left(F_{X}\right)_{I N}\right] * 100$

where,

$\left(\mathrm{F}_{\mathrm{X}}\right)_{\mathbb{N}}=$ molar flow of the species $\mathrm{x}$ at the reactor inlet, $\{\mathrm{mol} / \mathrm{min}\}$

$\mathrm{R}_{\mathrm{X}}=$ net corrected total rate of consumption of the reactants given by eq. E. $7,\{\mathrm{~mol} / \mathrm{min}\}$

\section{E.2.2 Yield of CO}

$\%$ Yield of $\mathrm{CO}=\left\{\mathrm{S}_{\mathrm{CO}} /\left[\left(\mathrm{F}_{\mathrm{CH} 4}\right)_{\mathrm{IN}}+\left(\mathrm{F}_{\mathrm{CO} 2}\right)_{\mathrm{IN}}\right]\right\} * 100$

where,

$\mathrm{S}_{\mathrm{CO}}=$ net corrected total rate of formation of $\mathrm{CO}$ given by eq. E.6, $\{\mathrm{mol} / \mathrm{min}\}$

$\left(\mathrm{F}_{\mathrm{CH} 4}\right)_{\mathbb{N}},\left(\mathrm{F}_{\mathrm{CO} 2}\right)_{\mathbb{N}}=$ molar flow of $\mathrm{CH}_{4}$ and $\mathrm{CO}_{2}$ at the reactor inlet, $\{\mathrm{mol} / \mathrm{min}\}$

\section{E.2.3 $\mathrm{H}_{2} / \mathrm{CO}$ Ratio}

$\mathrm{H}_{2} / \mathrm{CO}$ ratio $=\mathrm{S}_{\mathrm{H} 2} / \mathrm{S}_{\mathrm{CO}}$

where,

$\mathrm{S}_{\mathrm{H} 2}, \mathrm{~S}_{\mathrm{CO}}=$ net corrected total rate of formation of $\mathrm{H}_{2}$ and $\mathrm{CO}$ given by eq. E.6, $\{\mathrm{mol} / \mathrm{min}\}$ 


\section{E.2.4 Carbon balances}

Molar flow rate of all carbon species at the reactor inlet

$\operatorname{Cin}=\left(\mathbf{F}_{\mathbf{C H} 4}\right)_{\mathrm{IN}}+\left(\mathbf{F}_{\mathbf{C O} 2}\right)_{\mathrm{IN}}\{\mathrm{mol} / \mathrm{min}\}$

Molar flow rate of all carbon species at the reactor outlet

Cout $=\left(\mathbf{F}_{\mathbf{C H} 4}\right)_{\text {OUT }}+\left(\mathbf{F}_{\mathrm{CO} 2}\right)_{\text {OUT }}+\left(\mathbf{F}_{\mathbf{C O}}\right)_{\text {OUT }}\{\mathrm{mol} / \mathrm{min}\}$

where,

$\left(\mathrm{F}_{\mathrm{CH} 4}\right)_{\mathbb{I N}}\left(\mathrm{F}_{\mathrm{CO} 2}\right)_{\mathbb{N}}=$ molar flow of $\mathrm{CH}_{4}$ and $\mathrm{CO}_{2}$ at the reactor inlet, $\{\mathrm{mol} / \mathrm{min}\}$

$\left(\mathrm{F}_{\mathrm{CH} 4}\right)_{\mathrm{OUT}},\left(\mathrm{F}_{\mathrm{CO} 2}\right)_{\mathrm{OUT}},\left(\mathrm{F}_{\mathrm{CO}}\right)_{\mathrm{OUT}}=$ molar flow of $\mathrm{CH}_{4}, \mathrm{CO}_{2}$ and $\mathrm{CO}$ at the reactor outlet, $\{\mathrm{mol} / \mathrm{min}\}$

Now for the carbon balance, fractional difference in the carbon species $(\Delta \mathrm{C})$ is given as:

$\% \Delta \mathrm{C}=\{[$ Cout $-\operatorname{Cin}] / \operatorname{Cin}\} * 100$

$\%$ Carbon accounted $=\{$ Cout $/$ Cin $\} * 100$

$\mathbf{r}_{\mathrm{CD}}=[\mathbf{C i n}-\mathbf{C o u t}] / \mathbf{W} \quad\{\mathrm{mol} / \mathrm{min} /$ gcat $\}$

where,

$\mathbf{r}_{\mathbf{C D}}=$ rate of Carbon Deposition $(\mathrm{CD}),\{\mathrm{mol} / \mathrm{min} / \mathrm{gcat}\}$

$\mathrm{W}=$ weight of the catalyst used (grams) 


\section{APPENDIX F: Thermodynamic Analysis of Kinetic Data for $\mathrm{CO}_{2}$ Reforming of $\mathrm{CH}_{4}$}


The reaction scheme considered in our study (section 6.3.2) is as follows:

$$
\begin{aligned}
& \mathrm{CH}_{4}+\mathrm{CO}_{2} \longrightarrow 2 \mathrm{CO}+2 \mathrm{H}_{2} \quad \text { [Methane Reforming (MR)] } \\
& \mathrm{CO}_{2}+\mathrm{H}_{2} \longrightarrow \mathrm{H}_{2} \mathrm{O}+\mathrm{CO} \quad \text { (RWGS) }
\end{aligned}
$$$$
\mathrm{CH}_{4} \longrightarrow 2 \mathrm{H}_{2}+\mathrm{C} \quad \text { [Carbon Deposition (CD)] }
$$

$\mathrm{CO}_{2}+\mathrm{C} \longrightarrow 2 \mathrm{CO} \quad[$ Reverse Boudouard (RB)]

Now, from Sandler (1989) the activity of any species $i$ is given as:

$$
\mathbf{a}_{\mathbf{i}}=\mathbf{f}_{\mathbf{i}}\left(\mathbf{T}, \mathbf{P}, \mathbf{x}_{\mathbf{i}}\right) / \mathbf{f}_{\mathbf{i}}^{\mathbf{0}}\left(\mathbf{T}, \mathbf{P}_{\text {ref }}, \mathbf{x}_{\mathbf{i}}^{0}\right)
$$

where,

$\mathrm{f}_{\mathrm{i}}=$ fugacity of the component $\mathrm{i}$ in a mixture at $\mathrm{T}, \mathrm{P}$ with mole fraction $\mathrm{x}_{\mathrm{i}}$

$\mathrm{f}_{\mathrm{i}}^{\mathrm{o}}=$ fugacity of the pure component $\mathrm{I}$ in its standard state at $\mathrm{T}, \mathrm{P}_{\text {ref }}=1$ atm with mole fraction $\mathrm{x}_{\mathrm{i}}^{\mathrm{o}}=1$

Assuming ideal gas mixtures with standard state of unit activity we get,

$\left(\mathrm{f}_{\mathrm{i}} / \mathrm{P}_{\mathrm{i}}\right) \approx 1$ or $\mathrm{f}_{\mathrm{i}} \approx \mathrm{P}_{\mathrm{i}}$

Hence,

$\mathbf{a}_{\mathrm{i}}=\mathbf{P}_{\mathrm{i}} /\left(\mathbf{P}_{\text {ref }}=\mathbf{1} \mathbf{a t m}\right)$

where,

$\mathrm{P}_{\mathrm{i}}=$ partial pressure of species $\mathrm{i}$ expressed in atm

Now, the equilibrium constant $\mathrm{K}_{\mathrm{a}}$ for every reaction is given as:

$$
\begin{aligned}
& \mathbf{K}_{\mathbf{a}}(\mathbf{M R})=\left\{\left(\mathbf{a}_{\mathrm{CO}}\right)^{2} *\left(\mathbf{a}_{\mathrm{H} 2}\right)^{2}\right\} /\left\{\left(\mathbf{a}_{\mathrm{CH} 4}\right) *\left(\mathbf{a}_{\mathrm{CO} 2}\right)\right\} \\
& \mathbf{K}_{\mathbf{a}}(\mathbf{R W G S})=\left\{\left(\mathbf{a}_{\mathrm{CO}}\right) *\left(\mathbf{a}_{\mathrm{H} 2 \mathrm{O}}\right)\right\} /\left\{\left(\mathbf{a}_{\mathrm{H} 2}\right) *\left(\mathbf{a}_{\mathrm{CO} 2}\right)\right\}
\end{aligned}
$$


$\mathbf{K}_{\mathbf{a}}(\mathbf{C D})=\left\{\left(\mathbf{a}_{\mathrm{H} 2}\right)^{2}\right\} /\left\{\left(\mathbf{a}_{\mathrm{CH} 4}\right)\right\}$

$\mathbf{K}_{\mathbf{a}}(\mathbf{R B})=\left\{\left(\mathbf{a}_{\mathrm{CO}}\right)^{2}\right\} /\left\{\left(\mathbf{a}_{\mathrm{CO}}\right) *\left(\mathbf{a}_{\mathrm{C}}\right)\right\}$

where,

$\mathrm{a}_{\mathrm{C}}=$ activity of solid carbon

$\mathrm{a}_{\mathrm{C}}$ is assumed to be unity, as the solid carbon does not affect the activity of other species at operating pressures of $5 \mathrm{~atm}$. Thus, the activities of only the gaseous species are considered in the calculations.

Thus from the above equations the observed equilibrium ratios (RHS of eqs. F.7 F.10) are calculated from the partial pressure of each species for every run. The equilibrium constant, $\mathrm{K}_{\mathrm{a}}$, is obtained as a function of temperature from the software CHEMEQ.BAS developed by Sandler (1989). On comparing the observed ratios and the theoretical $\mathrm{K}_{\mathrm{a}}$, it is seen that all the four reactions (eqs. F.1, F.2, F.3 and F.4) are not at equilibrium for every run. The values are tabulated below. 
Table F.1 Observed equilibrium ratios and predicted equilibrium constants ( $\mathrm{K}_{\mathrm{a}}$ ) during the kinetic study of the $\mathrm{CO}_{2}$ reforming of $\mathrm{CH}_{4}$ (Particle size $<38 \mu \mathrm{m}$, weight of catalyst used $=0.3 \mathrm{~g}$, Total feed $\mathrm{WHSV}=11,200 \mathrm{scc} / \mathrm{hr} / \mathrm{g}$-catalyst., $P_{\text {total }}=$ 5 atm.)

\begin{tabular}{|c|l|l|l|l|l|l|}
\hline \multirow{2}{*}{ Label } & \multicolumn{2}{|c|}{ MR } & \multicolumn{2}{c|}{ RWGS } & \multicolumn{2}{c|}{ CD } \\
\cline { 2 - 7 } & $\mathbf{K}_{\mathbf{a}}$ & Obs ratio & $\mathbf{K}_{\mathbf{a}}$ & Obs ratio & $\mathbf{K}_{\mathbf{a}}$ & Obs ratio \\
\hline $\mathrm{AA}$ & 0.2025 & $3.2 \times 10^{-4}$ & 0.4044 & 0.2085 & 2.106 & 0.0058 \\
\hline $\mathrm{AB}$ & 0.2025 & $6.6 \times 10^{-4}$ & 0.4044 & 0.2246 & 2.106 & 0.0095 \\
\hline $\mathrm{AC}$ & 0.2025 & $9.1 \times 10^{-4}$ & 0.4044 & 0.2201 & 2.106 & 0.0123 \\
\hline $\mathrm{AD}$ & 0.2025 & $1.1 \times 10^{-3}$ & 0.4044 & 0.2269 & 2.106 & 0.0138 \\
\hline $\mathrm{AE}$ & 0.2025 & $9.6 \times 10^{-4}$ & 0.4044 & 0.2175 & 2.106 & 0.0131 \\
\hline $\mathrm{AF}$ & 0.2025 & $6.6 \times 10^{-4}$ & 0.4044 & 0.2404 & 2.106 & 0.0121 \\
\hline $\mathrm{AB}$ & 0.2025 & $5.2 \times 10^{-4}$ & 0.4044 & 0.2077 & 2.106 & 0.0085 \\
\hline $\mathrm{AG}$ & 0.2025 & $9.2 \times 10^{-4}$ & 0.4044 & 0.2011 & 2.106 & 0.0097 \\
\hline $\mathrm{AH}$ & 0.2025 & $6.8 \times 10^{-4}$ & 0.4044 & 0.1849 & 2.106 & 0.0071 \\
\hline $\mathrm{AI}$ & 0.2025 & $5.0 \times 10^{-4}$ & 0.4044 & 0.1699 & 2.106 & 0.0055 \\
\hline $\mathrm{BA}$ & 0.0230 & $1.6 \times 10^{-5}$ & 0.2978 & 0.1688 & 1.011 & 0.0010 \\
\hline $\mathrm{BB}$ & 0.0230 & $2.4 \times 10^{-5}$ & 0.2978 & 0.1784 & 1.011 & 0.0014 \\
\hline $\mathrm{BC}$ & 0.0230 & $3.3 \times 10^{-5}$ & 0.2978 & 0.1712 & 1.011 & 0.0017 \\
\hline $\mathrm{BD}$ & 0.0230 & $2.6 \times 10^{-5}$ & 0.2978 & 0.1748 & 1.011 & 0.0015 \\
\hline $\mathrm{BE}$ & 0.0230 & $2.2 \times 10^{-5}$ & 0.2978 & 0.1675 & 1.011 & 0.0014 \\
\hline $\mathrm{BF}$ & 0.0230 & $2.1 \times 10^{-5}$ & 0.2978 & 0.1834 & 1.011 & 0.0016 \\
\hline $\mathrm{BB}$ & 0.0230 & $2.6 \times 10^{-5}$ & 0.2978 & 0.1612 & 1.011 & 0.0015 \\
\hline $\mathrm{BG}$ & 0.0230 & $4.7 \times 10^{-5}$ & 0.2978 & 0.1696 & 1.011 & 0.0017 \\
\hline $\mathrm{BH}$ & 0.0230 & $3.7 \times 10^{-5}$ & 0.2978 & 0.1592 & 1.011 & 0.0013 \\
\hline $\mathrm{BI}$ & 0.0230 & $2.7 \times 10^{-5}$ & 0.2978 & 0.1486 & 1.011 & 0.0010 \\
\hline $\mathrm{CA}$ & 0.0020 & $1.8 \times 10^{-6}$ & 0.2097 & 0.1232 & 0.445 & $3.0 \times 10^{-4}$ \\
\hline $\mathrm{CB}$ & 0.0020 & $2.0 \times 10^{-6}$ & 0.2097 & 0.1306 & 0.445 & $3.4 \times 10^{-4}$ \\
\hline $\mathrm{CC}$ & 0.0020 & $2.1 \times 10^{-6}$ & 0.2097 & 0.1312 & 0.445 & $3.5 \times 10^{-4}$ \\
\hline $\mathrm{CD}$ & 0.0020 & $1.5 \times 10^{-6}$ & 0.2097 & 0.1284 & 0.445 & $2.6 \times 10^{-4}$ \\
\hline $\mathrm{CE}$ & 0.0020 & $7.1 \times 10^{-6}$ & 0.2097 & 0.1369 & 0.445 & $7.4 \times 10^{-4}$ \\
\hline $\mathrm{CF}$ & 0.0020 & $3.9 \times 10^{-7}$ & 0.2097 & 0.1276 & 0.445 & $1.6 \times 10^{-4}$ \\
\hline $\mathrm{CB}$ & 0.020 & $6.7 \times 10^{-7}$ & 0.2097 & 0.1100 & 0.445 & $1.8 \times 10^{-4}$ \\
\hline $\mathrm{CG}$ & 0.0020 & $1.8 \times 10^{-6}$ & 0.2097 & 0.1278 & 0.445 & $2.5 \times 10^{-4}$ \\
\hline $\mathrm{CH}$ & 0.0020 & $1.4 \times 10^{-6}$ & 0.2097 & 0.1217 & 0.445 & $2.0 \times 10^{-4}$ \\
\hline $\mathrm{CI}$ & 0.0020 & $1.2 \times 10^{-6}$ & 0.2097 & 0.1149 & 0.445 & $1.6 \times 10^{-4}$ \\
\hline & & & & & & \\
\hline
\end{tabular}


APPENDIX G: Kinetic Model for $\mathrm{CO}_{2}$ Reforming of $\mathrm{CH}_{4}$ 
In chapter 6 , a reaction mechanism and accompanying kinetic models for rates of formation of $\mathrm{H}_{2}, \mathrm{CO}$ and $\mathrm{H}_{2} \mathrm{O}$ during the $\mathrm{CO}_{2}$ reforming of $\mathrm{CH}_{4}$ are proposed. The reaction mechanism proposed is as follows:

$$
\begin{aligned}
& \mathrm{CH}_{4}+* \stackrel{\mathbf{K}_{1}}{\longrightarrow} \mathrm{CH}_{\mathbf{X}} *+(\mathrm{x} / 2) \mathrm{H}_{2} \\
& \mathrm{CO}_{2}+* \stackrel{\mathrm{K}_{2}}{\longrightarrow} \mathrm{CO}+\mathrm{O} * \\
& \mathrm{CH}_{\mathrm{X}} *+\mathrm{O} * \stackrel{\mathrm{k}_{3}}{\longrightarrow} \mathrm{CO}+(\mathrm{x} / 2) \mathrm{H}_{2}+2 * \\
& \mathrm{CH}_{\mathrm{X}} * \stackrel{\mathrm{K}_{4}}{\longrightarrow} \mathrm{C} *+(\mathrm{x} / 2) \mathrm{H}_{2} \\
& \mathrm{H}_{2}+\mathrm{O} * \stackrel{\mathrm{k}_{5}}{\mathrm{k}-5} \mathrm{H}_{2} \mathrm{O}+* \\
& \mathrm{C} *+\mathrm{O} * \stackrel{\mathrm{k}_{6}}{\longrightarrow} \mathrm{CO}+2 *
\end{aligned}
$$

Now steps 1,2 and 4 are in equilibrium while steps 3 and 6 are irreversible rate determining steps. Step 5 represents the RWGS reaction that is reversible but not in equilibrium. The carbon that is deposited is assumed to be in the activated form represented as $\mathrm{C}^{*}$.

Assuming $\mathrm{x}=2$ for the above reaction sequence, the equilibrium constants for steps 1,2 and 4 can be given as:

$$
\begin{gathered}
K_{1}=\frac{\theta_{\mathrm{CH}_{2}} P_{\mathrm{H}_{2}}}{\theta_{S} P_{C H_{4}}} \\
K_{2}=\frac{\theta_{O} P_{\mathrm{CO}}}{\theta_{S} P_{C O_{2}}}
\end{gathered}
$$




$$
K_{4}=\frac{\theta_{C} P_{H_{2}}}{\theta_{C H_{2}}}
$$

where,

$\theta_{\mathrm{CH} 2}, \theta_{\mathrm{C}}, \theta_{\mathrm{O}}=$ surface coverage of adsorbed $\mathrm{CH}_{2}, \mathrm{C}$ and $\mathrm{O}$ respectively

$\theta_{\mathrm{S}}=$ surface coverage of free active site

$\mathrm{P}_{\mathrm{i}}=$ partial pressure of component $\mathrm{i}$

Now from the total active site balance we get:

$\theta_{\mathrm{CH} 2}+\theta_{\mathrm{C}}+\theta_{\mathrm{O}}+\theta_{\mathrm{S}}=1$

Now from eqs. G.7 - G.9 we get:

$\theta_{\mathrm{CH}_{2}}=\frac{K_{1} P_{\mathrm{CH}_{4}} \theta_{S}}{P_{\mathrm{H}_{2}}}$

$\theta_{O}=\frac{K_{2} P_{C_{2}} \theta_{S}}{P_{C O}}$

$\theta_{C}=\frac{K_{1} K_{4} P_{C_{4}} \theta_{S}}{P_{H_{2}}^{2}}$

Solving for $\boldsymbol{\theta}_{\mathrm{S}}$ from eqn G.10 - G.13 we get,

$$
\theta_{S}=\frac{1}{1+K_{1}\left(\frac{P_{C_{4}}}{P_{H_{2}}}\right)+K_{2}\left(\frac{P_{C O_{2}}}{P_{C O}}\right)+K_{1} K_{4}\left(\frac{P_{C H_{4}}}{P_{H_{2}}^{2}}\right)}
$$


Now from the reaction sequence (eqs. G.1-G.6) the rates of formation for each of the product species can be written as:

$$
\begin{aligned}
& \mathbf{r}_{\mathrm{CO}}=k_{3} \theta_{\mathrm{CH} 2} \theta_{\mathrm{O}}+k_{6} \theta_{\mathrm{C}} \theta_{\mathrm{O}} \\
& \mathbf{r}_{\mathrm{H} 2}=\mathbf{k}_{3} \boldsymbol{\theta}_{\mathrm{CH} 2} \boldsymbol{\theta}_{\mathrm{O}}+k_{-5} \mathbf{P}_{\mathrm{H} 2 \mathrm{O}} \theta_{\mathrm{S}}-k_{5} \mathbf{P}_{\mathrm{H} 2} \theta_{\mathrm{O}} \\
& \mathbf{r}_{\mathrm{H} 2 \mathrm{O}}=k_{5} \mathbf{P}_{\mathrm{H} 2} \theta_{\mathrm{O}}-k_{-5} \mathbf{P}_{\mathrm{H} 2 \mathrm{O}} \theta_{\mathrm{S}}
\end{aligned}
$$

Now, substituting the expressions for surface coverage of each species from eqs. G.11 G.14 in the above rate expressions (eqs. G.15 - G.17), we get the final kinetic models for the rates of formation of product species $\left(\mathrm{H}_{2}, \mathrm{CO}\right.$ and $\left.\mathrm{H}_{2} \mathrm{O}\right)$ as follows:

$$
\begin{aligned}
& r_{\mathrm{CO}}=\frac{K_{1} K_{2}}{(\text { den })^{2}}\left(\frac{P_{\mathrm{CH}_{4}} P_{\mathrm{CO}_{2}}}{P_{\mathrm{CO}} P_{\mathrm{H}_{2}}}\right)\left(k_{3}+\frac{k_{6} K_{4}}{P_{\mathrm{H}_{2}}}\right) \\
& r_{\mathrm{H}_{2}}=\frac{k_{3} K_{1} K_{2}}{(\text { den })^{2}}\left(\frac{P_{\mathrm{CH}_{4}} P_{\mathrm{CO}_{2}}}{P_{\mathrm{CO}} P_{\mathrm{H}_{2}}}\right)-\frac{k_{5} K_{2}}{(\text { den })}\left(\frac{P_{\mathrm{H}_{2}} P_{\mathrm{CO}_{2}}}{P_{\mathrm{CO}}}\right)+\frac{k_{-5} P_{\mathrm{H}_{2} \mathrm{O}}}{(\text { den })} \\
& r_{\mathrm{H}_{2} \mathrm{O}}=\frac{k_{5} K_{2}}{(\text { den })}\left(\frac{P_{\mathrm{H}_{2}} P_{\mathrm{CO}_{2}}}{P_{\mathrm{CO}}}\right)-\frac{k_{-5} P_{\mathrm{H}_{2} \mathrm{O}}}{(\text { den })}
\end{aligned}
$$

where:

$$
\text { den }=1+K_{1}\left(\frac{P_{C_{4}}}{P_{H_{2}}}\right)+K_{2}\left(\frac{P_{C O_{2}}}{P_{C O}}\right)+K_{1} K_{4}\left(\frac{P_{C_{4}}}{P_{H_{2}}^{2}}\right)
$$

